\title{
The Child's Right to Development
}

Noam Peleg

A thesis submitted to University College London for the degree of Doctor of Philosophy

November 2012 
I, Noam Peleg, confirm that the work presented in this thesis is my own. Where information has been derived from other sources, I confirm that this has been indicated in the thesis.

\section{Noam Peleg}




\section{$\underline{\text { Abstract }}$}

Protecting children's development is a key principle of international children's rights law. However, while the meanings of children's development are a central concern of disciplines such as psychology, sociology, neurology and pedagogy, so far there has been no systematic analysis of the meaning of the child's legal right to development. This thesis remedies this significant gap in our knowledge by establishing the foundations for analysing the child's right to development, as protected by the UN Convention on the Rights of the Child.

Interpreting the child's right to development first requires unpacking the meaning of the term 'children's development'. In international children's rights law, the thesis argues that the meaning of this term derives from the concept of children as 'human becomings'. The focal point of this concept is the protection of children's socio-psychological development and caring for their future, as adults. Consequently, the UN Convention on the Rights of the Child provides a broad protection for eight segments of children's development, on top of protecting children's overall right to development. Based on an analysis of the UN Committee on the Rights of the Child's jurisprudence between the years 1993 and 2010, the thesis concludes that the Committeeinterprets the Convention in a way that subjugated most of the Convention's rights to protect children's socio-psychological development, while overlooking the formulation of 'development' as a human right.

Based on literature on childhood studies, children's rights theory, children's development, the Capability Approach, archival research of the drafting process of the Convention, the jurisprudence of the UN Committee on the Rights of the Child, and interviews with members of the UN Committee, the thesis challenges this absorption of 'children's development' into legal terms, and suggests a new framework for analysis.

This framework accommodates a hybrid conception of childhood, a respect for children's agency, recognition of the importance of the process of maturation ('development') as well as its outcome, and a cross-disciplinary understanding of 'development'. Under the suggested framework, the child's right to development is interpreted as a composite right that aims to ensure the child's abilities to fulfil her or his human potentialto the maximum during childhood and adulthood alike. 


\section{Acknowledgements}

Writing this thesis would not have been possible without the guidance, support and help of many friends, colleagues and family members.

I owe much to my supervisors, Professor Michael Freeman and Mr. Colm O'Cinneide. The long conversations I have had with Professor Freeman helped me to shape my thoughts about childhood, law and children's rights. It was a huge privilege and a great honour to have these discussions with him. I doubt that I will ever be able to convey my appreciation fully, but I owe him my eternal gratitude. Mr. O'Cinneide's sharp observations and excellent critique constantly challenged my arguments, and helped me to make this thesis, so I hope, better.

I would like to thank the members of the UN Committee on the Rights of the Child for the willingness to share their thoughts, experience and expertise with me, during the very busy sessions of the Committee. Their hard work and dedication are rarely acknowledged. I would like to thank Ms. Hadeel Al-Asmar, Ms. Aseil Al-Shehail, Ms. Maria Herczog, Mr. Lothar Krappmann, Ms. Yanghee Lee, Mr. Gehad Madi, Ms. Awich Pollar, Mr. Hiranthi Wijemanne, and Mr. Jean Zermatten. The kind assistance of Ms. Cristina Giordano from the UN Library in Geneva gave me invaluable access to archival materials about the drafting history of the Convention on the Rights of the Child.

The UCL Faculty of Laws Research Students Scholarship allowed me to dedicate my time to this research. Additional financial support from UCL Laws and UCL Graduate School enabled me go on number of research trips to Geneva. The Chevening/Chaim Herczog UCLAlumni Association in Israel Award funded my LLM Studies in UCL.

Aeyal Gross has been a mentor, a colleague, and a friend. His encouragement and support during the last ten years were invaluable to me.From Ruty Zafran, Zvika Triger, Saviona Rotlevy and Dan Gibton I have learned in different stages of my academic and professional life. Their contributions can be found in every page of this thesis.

My dear friends in Tel Aviv and London, Ally, Amikam, Barak, Danai, Francois, Hadas, Katherine, Keren, Kristen, Moran, Ofer, Pritam, Shay (the girl), Shay (the boy), Tal and Tuli and many others were an exceptional source for strength, especially in times when I was not as sociable as a friend should be. 
Without the love and encouragement of Lana Tatour I would not have started, let alone finished, writing this thesis. Her wisdom, insights and intellect significantly improved my work. I apologise for being such a pain for too many nights and weekends.

My work on children's rights, particularly on the child's right to development, was, and still is, inspired by the love and support of my parents, Hava and Uri. Thank you. 


\section{Table of Content}

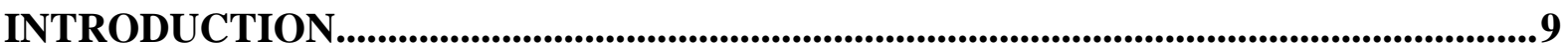

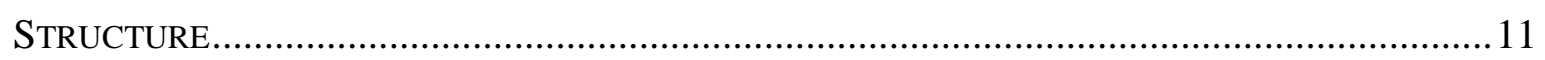

ChILdHood STUdies AND THE IMAGE OF THE DEveloping CHILD ...................................... 14

CHAPTER ONE: EMBEDDING THE CONCEPT OF 'CHILDREN'S

DEVELOPMENT’ INTO INTERNATIONAL CHILDREN'S RIGHTS LAW ............24

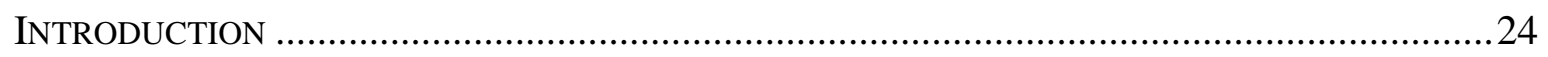

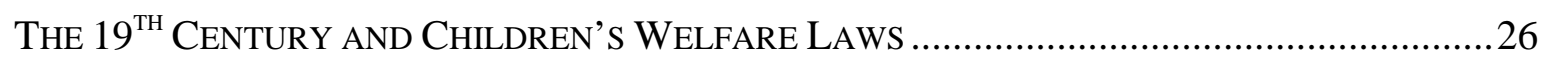

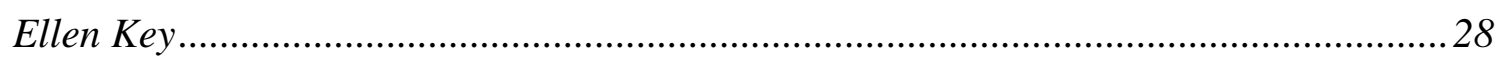

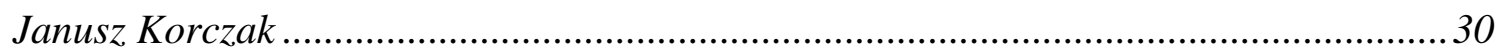

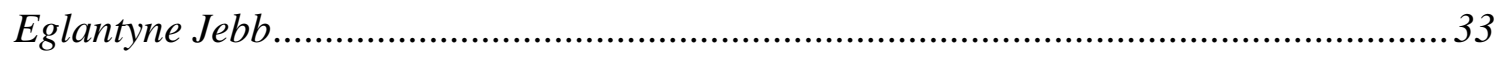

1924 LEAGUE of NATIONS DECLARATION ON THE RIGHTS OF THE CHILD..............................35

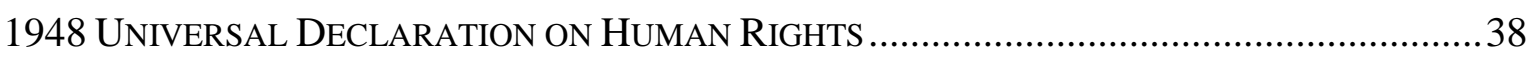

1959 UN DECLARATION ON THE RIGHTS OF THE CHILD ..................................................... 40

THE 1960's AND the EMERGING RECOGNITION OF CHILDREN's AutONOMY ......................44

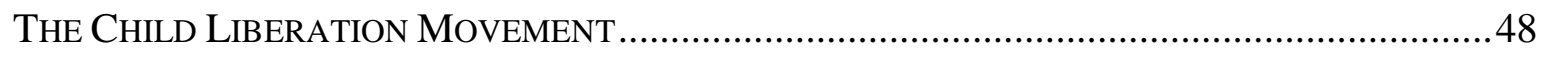

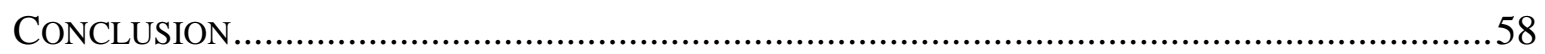

CHAPTER TWO: CREATING THE RIGHT TO DEVELOPMENT OF CHILDREN61

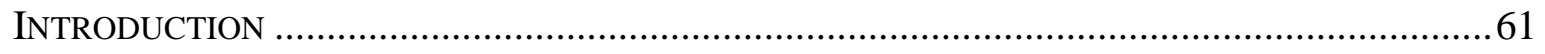

'We Should Have a Convention on the Rights of the Child' - The First Draft of

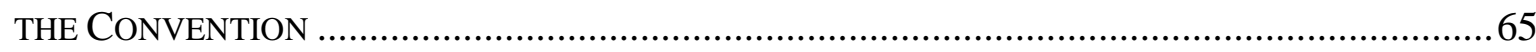

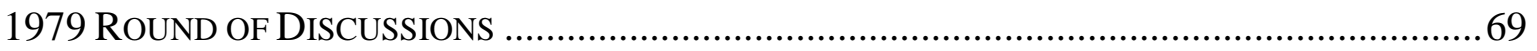

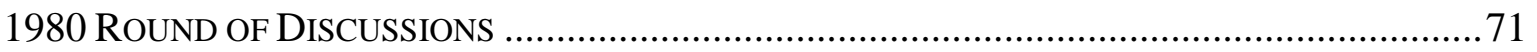

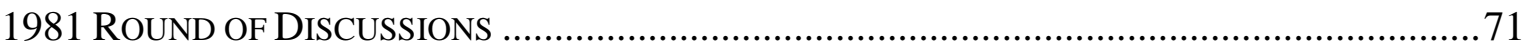

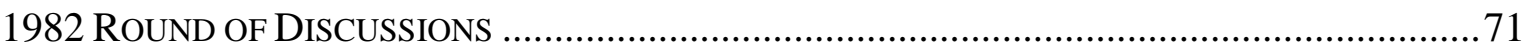

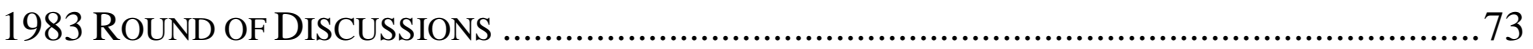

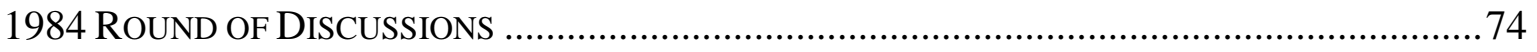

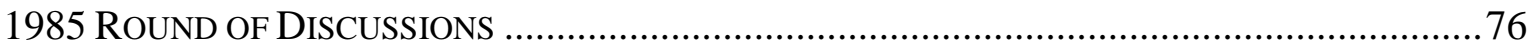

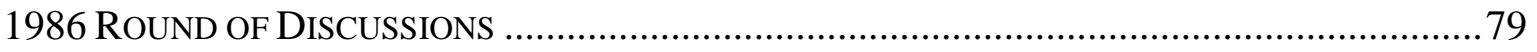

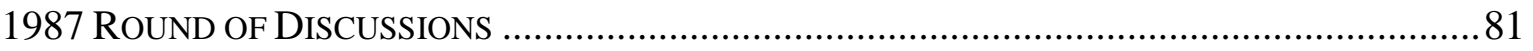

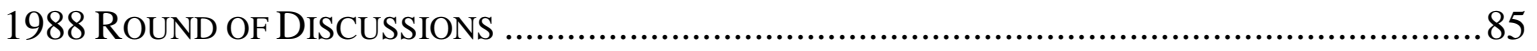

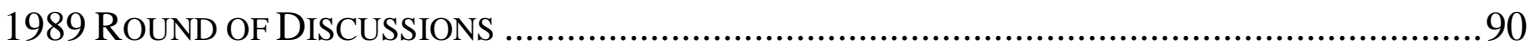

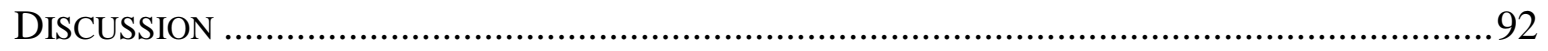

Embedding the Protection of 'Children's Development' in the Convention ....................93

Understanding Article 6 and the Rights to Life and Survival.......................................95

Understanding Article 6 and the Right to Development ................................................ 97 
The Convention and the Right to Development in 'General' International law ..... .98

CONCLUSION.

CHAPTER THREE: THE UN COMMITTEE ON THE RIGHTS OF THE CHILD'S JURISPRUDENCE ON THE RIGHT TO DEVELOPMENT.

INTRODUCTION 100

The COMmitTeE’s Normative Status AND Methods OF WORK .... 102

METHODOLOGY 104

From CRAdle to AdulthoOd - The COMMITTEE'S PERSPECTIVE ON CHILDREN'S

DEVELOPMENT AND RIGHT TO DEVELOPMENT 105

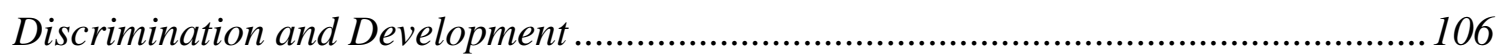

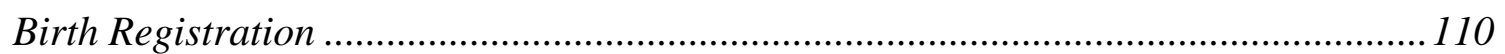

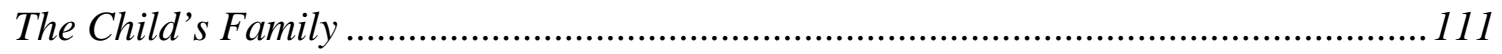

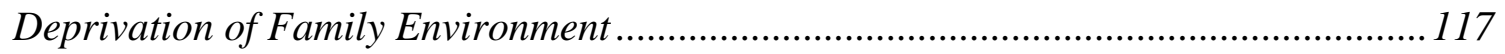

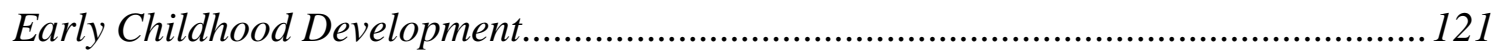

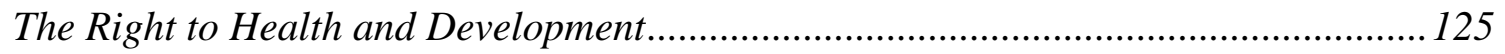

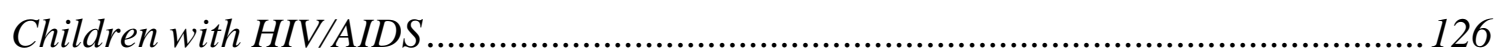

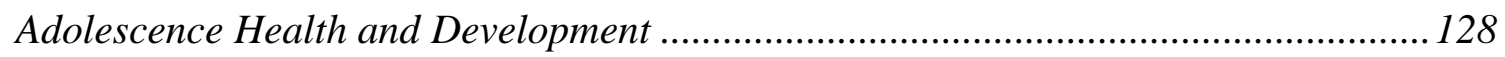

Poverty and Adequate Standard of Living .................................................................. 130

Children who Work and/or Live on the Street .............................................................. 132

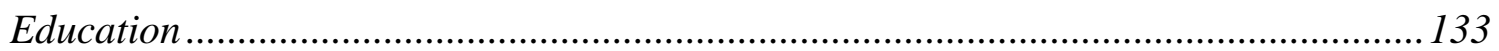

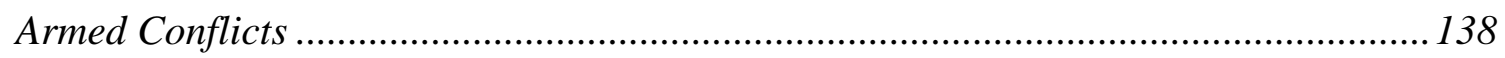

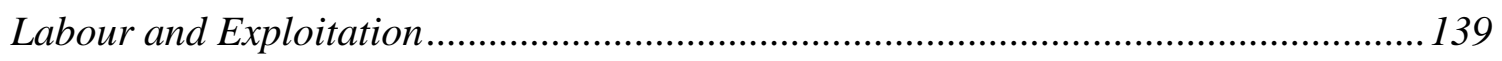

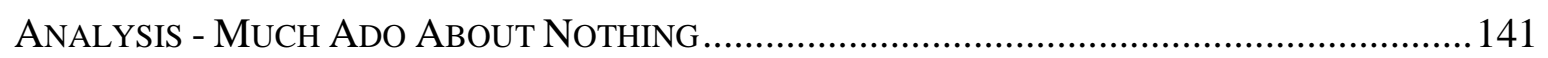

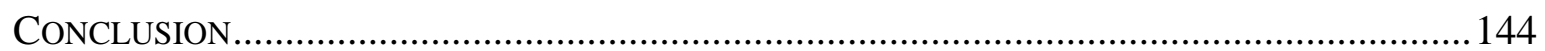

CHAPTER FOUR: THE PERSPECTIVE OF MEMBERS OF THE UN COMMITTEE ON THE RIGHTS OF THE CHILD ON THE RIGHT TO DEVELOPMENT.............146

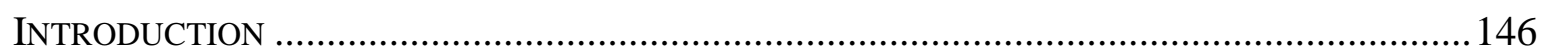

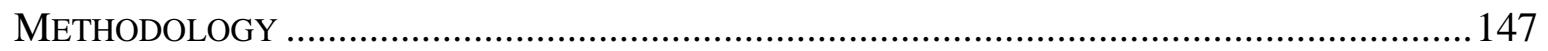

THE INTERVIEWS - BetweEn LACK OF AwARENESS AND CONCEPTUAL CHALlENGES .......148

States Parties Ignore the Right to Development .......................................................... 149

The Committee Ignores the Right to Development ...................................................... 151

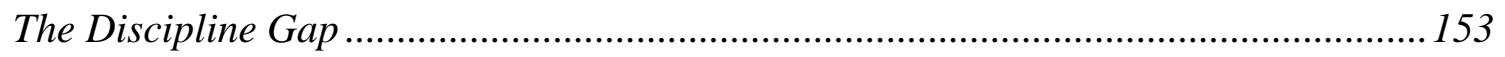

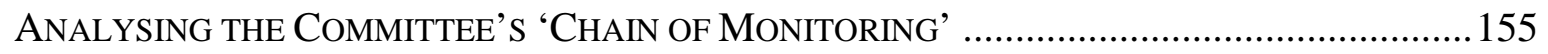

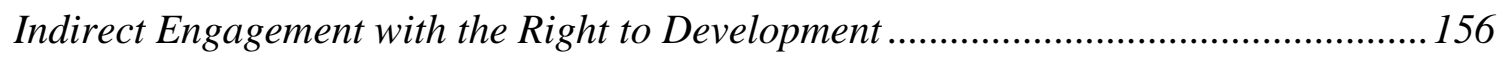

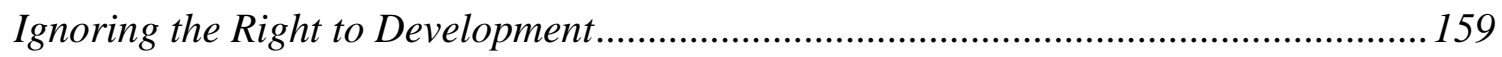

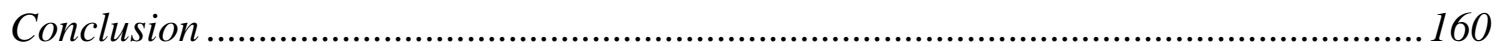

How The Committee Should Approach the Right to Development? ....................... 161 


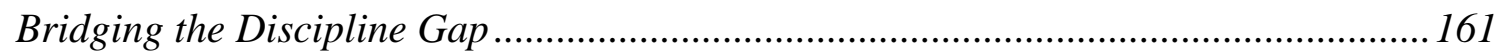

Between a Distinct Right and a Guiding Principle..................................................... 163

What Does 'Children's Development' Mean? ........................................................... 165

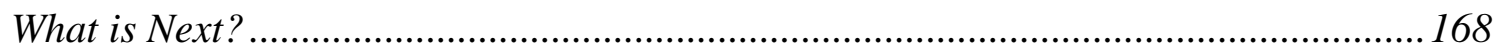

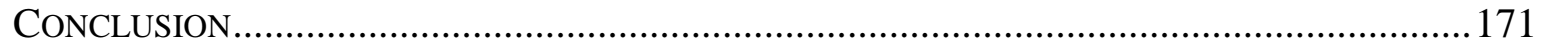

CHAPTER FIVE: COMPARATIVE ANALYSIS OF HUMAN AND CHILDREN'S 'DEVELOPMENT' ..........................................................................................................173

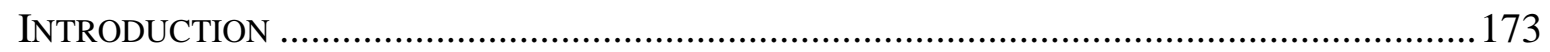

THE Right to DEVELOPMENT IN ‘GeneraL’ INTERNATIONAL Human Rights LAW.........175

The Creation of the Right to Development ................................................................... 175

The Meaning of 'Development' in the 'Right to Development' '....................................... 177

Distinguishing Between The Process of Development and Its Outcome........................179

Respect for People's Agency and Their Right to Participation..................................... 180

Between an Individual and a Collective Right............................................................181

Conclusion - What Can the Right to Development Contribute to the Analysis of the

Child's Right to Development? ............................................................................... 183

THE CAPABILITY APPROACH AND THE CHILD’s Right To DEVELOPMENT ............................184

The Meaning of 'Development' According to the Capability Approach........................ 185

Fostering The Recognition of Children's Agency and Participation ............................. 194

Utilising the Capability Approach to Concretise 'Children's Development'.................196

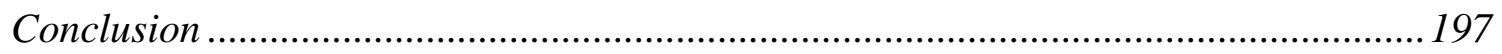

MEASURING CAPABILITIES - the HuMAN DEVELOPMENT REPORT......................................198

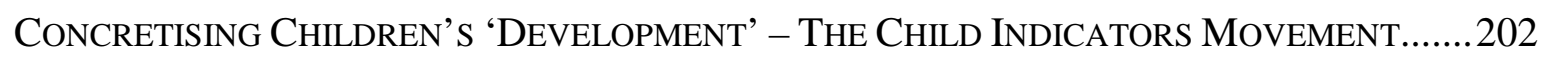

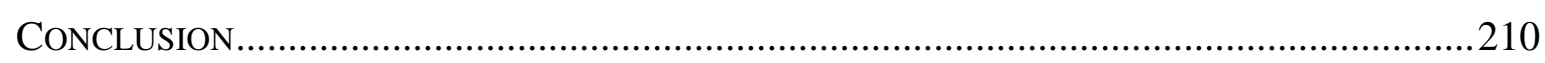

CHAPTER SIX: A NEW FRAMEWORK TO ANALYSE THE CHILD'S RIGHT TO

DEVELOPMENT .................................................................................................................211

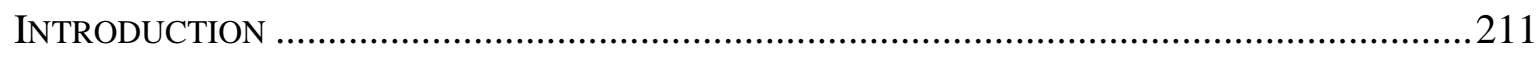

CONTEXTUALISING THE Discussion: CHILDREN's RighTS ANd CHILDREN's DEvELOPMENT

A ROADMAP FOR CHANGE ...............................................................................214

Upholding Children's Agency and Right to Participation ............................................2217

Re-Conceptualising 'Children's Development'..........................................................219

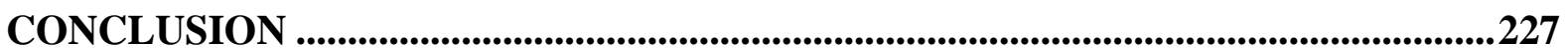

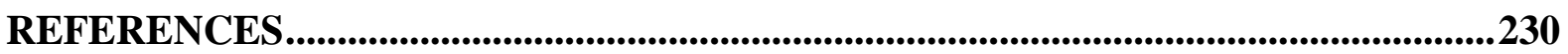




\section{Introduction}

The image of children as developing human beings dominated childhood studies throughout the $20^{\text {th }}$ century. 'How children grow up', 'what constitutes a normal course of maturation' and 'how children's development can best be fostered' are some of the questions asked in anthropology, sociology, medicine, history, psychology and pedagogy. International children's rights law is concerned with similar questions. Dating back to the 1924 League of Nations' Declaration on the Rights of the Child, one of the main aims of international children's rights law, if not the most important one, has been to ensure children's development. Therefore, Article 6 of the 1989 UN Convention on the Rights of the Child ('The Convention'), the most ratified human rights treaty of all, protects the child's right to development. In addition, five other articles of the Convention (Articles 18(1), 23(3), 27(1), 29(1)(a) and 32(1))protect eight specific developmental domains. These include physical, mental, moral, social, cultural, spiritual, personality and talent. No similar protection to human development or to the right to development can be found in any other binding international human rights treaty. ${ }^{2}$

Despite the prominence of the child's right to development, there has yet to be any systematic analysis of its meaning. Only scarce attention has been paid to this right, mostly in the context of discussing it as a derivative of other rights of the child, ${ }^{3}$ or focusing on the meaning of 'children's development', overlooking its articulation in human rights terms. ${ }^{4}$ This thesis plugs this gap by suggesting a framework through which to analyse the meaning of the child's legal right to development.

The premise of this thesis is that the child's right to development should be critically analysed within the context of the Convention. The connection between different images of 'the child', the realisation of children as rights holders and its influences on the interpretation of children's rights underpins my analysis. Therefore, this thesis analyses the protection for

\footnotetext{
${ }^{1}$ Martin Woodhead, 'Child Development and the Development of Childhood' in Jens Qvortrup et al (eds) The Palgrave Handbook of Childhood Studies (Palgrave, Basingstoke 2009, 2011) 46-61.

2 On the regional level, Article 5(2) of the African Charter on the Rights and Welfare of the Child protects the child's right to 'survival, protection and development'.

3 Manfred Nowak, Article 6: The Right to Life, Survival and Development (Martinus Nijhoff Publishers, Leiden 2005) 43-49; James R. Himes, 'Children's Rights: Moralists, Lawyers and the Right to Development' (1993) 1 International Journal of Children's Rights 81; Douglas Hodgson, 'The Child's Right to Life, Survival and Development' (1994) 2 International Journal of Children's Rights 369; Geraldine Van Bueren, The International Law on the Rights of the Child (Martinus Nijhoff Publishers, The Hague1998) 318-320.

${ }^{4}$ Martin Woodhead, 'Early Childhood Development: A Question of Rights' (2005) 37 International Journal of Early Childhood 80.
} 
the child's right to development in international children's rights law against the Convention's perspectives of children and childhood. The thesis asks how constructions of childhood guided the creation of the child's right to development in international children's rights law, how they informed the interpretation of this right, and what the shortcomings of this interpretation are.

I argue that the significance of the conception of children as 'human becomings' and the care for the child's future led international children's rights law to provide wide protection for children's development and their right to development. Dominated by developmental psychology discourse, ${ }^{5}$ the 'human becomings' approach perceives the child as weak, vulnerable, lacking agency and in need of protection. Childhood has primarily been characterised as a journey towards adulthood. ${ }^{6}$ Consequently, the right to development has been viewed as relating to what seems to be the natural course of life - the transformation of a child into an adult. The fixation with the care for children's future did not end even when a paradigm shift in childhood studies allegedly took place during the 1970's. According to the new 'human beings' approach to childhood, children are seen as active agents in their lives, families and communities, and as human rights bearers. ${ }^{7}$ While the Convention on the Rights of the Child includes some articles that reflect this new paradigm, for example the recognition of the child's right to participation (Article 12), the right to freedom of expression (Article 13), and the right to freedom of thought, and conscience and religion (Article 14), the 'human beings' conception has not been used to interpret the right to development, since it fundamentally contradicts the normative grounds that underpin the right to development.

The care for the child's future while overlooking the child's life as a child in the present is where the main gap in the interpretation of the child's right to development lies. The thesis highlights this gap, and suggests a socio-legal explanation for it, arguing that the difficulty in understanding children's development in terms of human rights is situated within the difficulty of translating children's psycho-social development into human rights norms. The care for the child's future cannot, and should not, be overlooked. However, at the same time, I argue that the child's present existence should not be ignored either. Therefore, caring for children's lives in the present, while they are still children, and recognising their freedom to

\footnotetext{
${ }^{5}$ Erica Burman, Development - Child, Image, Nation (Routledge, London 2008) 163-171.

${ }^{6}$ Nick Lee, Childhood and Society (Open University Press, Gosport 2001) 5-19.

${ }^{7}$ Alan Prout and Allison James, 'A New Paradigm for the Sociology of Childhood? Provenance Promise and Problems' in Allison James and Alan Prout (eds) Constructing and Reconstructing Childhood (2 ${ }^{\text {nd }}$ edition, Routledge Falmer, London 1997) 7-33.
} 
be active agents in shaping their destiny and their right to grow up to become what they want, requires a twofold conceptual shift.

First, there is a need to recognise that the care for children's development is an issue of human rights, and not only of welfare. Second, I suggest reconstructing the conception of childhood and of 'children's development', so that the term incorporates broad, crossdisciplinary meanings, rather than being bound by developmental psychology. These two paradigm shifts will enable us to redefine the meaning of the child's right to development, and to interpret it as the child's right to fulfil her or his human potential to the maximum.

\section{$\underline{\text { Structure }}$}

The thesis consists of six chapters following this introduction. The introduction contextualises the thesis in the framework of childhood studies, and elaborates on the main images of childhood that inform international children's rights law.

Chapter one reviews the history of protecting children's development in international children's rights law, focusing on key children's rights theorists and legal paradigms. The chapter establishes the connection between the ways that childhood is conceived, and the type of legal protection given to 'children's development'. The chapter starts by reviewing the late $19^{\text {th }}$ century and early $20^{\text {th }}$ century attitudes towards childhood, focusing on the writings of three key theorists that worked during that period (Janusz Korczak, Ellen Key and Eglantyne Jebb). The chapter then analyses the first two international children's rights law's instruments: the 1924 League of Nations Declaration on the Rights of the Child and the 1959 UN Declaration on the Rights of the Child. The image of children in international children's rights law is compared with the image of children in the Universal Declaration on Human Rights and the two 1966 Covenants (the International Covenant on Civil and Political Rights and the International Covenant on Economic, Social and Cultural Rights). Lastly, the chapter studies the key texts of the 1970's child liberation movement and their approach towards children's development and human rights.

Chapter two studies the drafting history of the UN Convention on the Rights of the Child. It unveils the motivations, intentions and ethical beliefs that led to the creation of the child's right to development. Based on comprehensive archival research, the chapter shows that while the Convention's drafters were keen to protect children's development, the question of what 'children's development' means was rarely raised. Furthermore, no significant 
discussions were held about the implications of formulating the care for children's development as a matter of legal right. The drafting process resulted in the creation of a complex structure that relates to eight domains of children's development, including a general clause that protects the right to development. Based on the history of international children's rights law, the drafting process and the prevailing conception of childhood at the time of drafting, the chapter suggests that the right to development can be understood as a right of the child to have her or his needs for a healthy growth met, in order to enable the child to become an adult.

Chapter three analyses the UN Committee on the Rights of the Child's jurisprudence on the right to development. By reviewing all of the Committee's work between 1993 and 2010, the chapter asks how the Committee understands the meaning of the right to development, and how it articulates the relationships between the right to development and other rights of the Convention. The chapter shows how the Committee subjugated most of the Convention's rights to support the child's maturation process, whilesimilar to the Convention's drafters, ignoring the right to development. The chapter argues that although the Committee repeatedly praises the importance of protecting the child's right to development and defines it as one of the Convention's four guiding principles, it fails to provide a distinct, meaningful, concrete or practical definition of the right. This failure is the result of upholding the 'human becomings' conception of childhood, which inherent limitations led the Committee to ignore children's agency and the articulation of the care for children's development as a matter of human rights.

Chapter four studies the work of the Committee from a different perspective. The chapter is based on in-depth interviews with nine current and former members of the Committee, as well as an analysis of the Committee's 'chain of monitoring, ${ }^{8}$ taking the year 2010 as a case study. The chapter offers further explanations for the gaps between the symbolic importance of the right to development and the Committee's unsatisfying jurisprudence concerning this right. Three explanations for this gap are concluded from the interviews: a lack of conceptual clarity of the meaning of 'the child's right to development', which in turn led the Committee to ignore it; insufficient information given by States Parties limits the Committee's abilityto fulfilits role as a monitoring body; and a sincere account by one member of the Committee, which admitted that the Committee forgot that this right exists. The claims concerning the

\footnotetext{
8 The Committee's 'chain of monitoring' refers to States Parties' implementations reports, the Committee's follow up questions ('List of Issues') and the Committee's Concluding Observations.
} 
States Parties' lack of reporting are empirically challenged with an analysis of the Committee's 'chain of monitoring'. The findings show that regardless of whether a State Party relates to the child's right to development in its implementation report, or not, the Committee is most likely to ignore the right to development in its follow-up questions and / or Concluding Observations. The chapter concludes with the interviewees' recommendations about future steps that the Committee should take in order to promote the protection of the child's right to development. One of the key suggestions is to inform legal professionals (lawyers, judges, academics) about the various meanings of children's development.

Chapter five addresses three issues that were identified as impediments in the process of interpreting the child's right to development: the potential meanings of 'children's development'; the ability to articulate these meanings in human rights terms; and the prospects of concretising these meanings. The chapter therefore analyses the meaning of 'development' in comparison to two instruments: the 'general' right to development in international law (i.e - international human rights law that is not group specific); and according to the Capability Approach (also known as 'the Human Development Paradigm'), which thus far has been 'under-theorized in relation to children'9. According to both frameworks, 'development' refers to collective mobilization, emancipation, democratic values of participation, empowerment, recognition of the agency of every human being, and individual prosperity. The chapter suggests that since the 'general' right to development and the child's right to development share the yardstick of growth - either economic growth or personal maturation - a comparison between the two can enable us to expand the interpretation of the child's right to development. I further suggest that using the Capability Approach's concept of 'human development' in the context of children's rights can broaden the scope of the right, so it will mean more than ensuring the child's process of growth. The second-half of the chapter presents key components of the Child Indicator Movement. This movement refers to various projects that employ and concretise different ideas of 'children's development'. I argue that the indices'fragments of 'children's development' have the potential to concretise the analysis of the child's right to development.

The last chapter concludes the thesis by suggesting a new framework for the interpretation of the child's right to development. The framework proposes to uphold three key principles: a hybrid conception of childhood, which synthesis the 'human beings' and 'human becomings'

\footnotetext{
9 Kaushik Basu, 'Prologue' in Mario Biggeri et al (eds) Children and the Capability Approach (Palgrave Macmillan, Basingstoke 2011) x.
} 
conceptions of childhood; respect for the child's agency; and a distinction between the right to development as a guiding principle of the Convention and as a separate human right of children. I argue that this framework can be meaningful and can be implemented on the ground if used in conjunction with a cross-disciplinary understanding of 'children's development'. Without a common language and knowledge about the various meanings of 'children's development', the interpretation of the right to development is destined to continue to suffer from the same problems it suffers now, mainly lack of coherence and inability to concretise it in human rights terms.

\section{Childhood Studies and the Image of the Developing Child}

The study of childhood suggests that childhood is neither natural nor neutral, ${ }^{10}$ but rather a socially constructed concept. ${ }^{11}$ Childhood is the nexus of structure, agency, moral convictions and social transformations. ${ }^{12}$ Adults have created 'childhood' as a social category using their own point of view of society, ${ }^{13}$ in order to define the child as the negative other. ${ }^{14}$ According to Erica Burman, separating people on the bases of age and capacities enables adults more easily to control, colonise and 'civilise' children. ${ }^{15}$

Childhood is not a new social construction in Western cultures, ${ }^{16}$ and its meaningshavenot remained unchanged over time. ${ }^{17}$ Childhood is constructed according to social views about family values, gender roles, the labour market, political views and attitudes toward crime and

\footnotetext{
10 Allison James et al, Theorizing Childhood (Polity, Cambridge 1998) 126-128.

11 Allison James and Adrian James, Constructing Childhood (Palgrave Macmillan, Basingstoke 2004) 10-26.

12 Prout and James 1990, supra n. 7; James et al, supra n. 10.

13 Lee, supra n. 6, 102.

14 David Archard, 'Philosophical Perspectives on Childhood' in Julia Fionda (ed) Legal Concepts of Childhood (Hart Publishing, Oxford 2001) 43-56, 46.

${ }^{15}$ Erica Burman, Deconstructing Development Psychology (2 $2^{\text {nd }}$ edition, Palgrave, London 2008) 77.

${ }^{16}$ Colin Heywood, 'Centuries of Childhood: An Anniversary - And an Epitaph?' (2010) 3 Journal of History of Childhood and Youth 343, 357-358; Richard T. Vann, 'The Youth of Centuries of Childhood' (1982) 21 History and Theory 279. Though at the early stages of writing the history of childhood, a half a century ago, it was argued by Philippe Ariès in Centuries of Childhood,that childhood as a social conception was invented only at the seventeen-century. See Philippe Ariès, Centuries of Childhood - A Social History of Family Life (Translated by Robert Baldick, Jonathan Cape, London 1962). For a contesting argument see Rex and Wendy Stainton Rogers, Stories of Childhood (University of Toronto Press, Toronto 1992) 65-66; Ariès' method and sources were grounds for harsh critique. See Adrian Wilson, 'The Infancy of the History of Childhood: An Appraisal of Philippe Aries' (1980) 19 History and Theory 132.

17 Suzanne Shanahan, 'Lost and Found: The Sociological Ambivalence Towards Childhood' (2007) 33 Annual Review of Sociology 407.
} 
punishment and religion, to name just a few of the most influential factors. ${ }^{18}$ For example, if childhood was once considered as a time of innocence and purity, in other times if was seen as a time of depravity. ${ }^{19}$ Children were once seen as 'little angels' and in different times they were perceived as 'little devils'. Thomas Hobbes, for example, characterised children as malicious as adults, while John Locke thought that it is parents' economic pressure that shapes children's behaviour. ${ }^{20}$ In the early twenty century, and with the influence of capitalism and consumerism, childhood was seen as a time of happiness and cheerfulness. ${ }^{21}$

These social attitudes towards children and childhood influence the ways in which law treats children. But law, as a powerful social instrument, also has a pivotal role in the institutionalisation $^{22}$ and conceptualising of childhood. ${ }^{23}$ Law shapes, develops and reconceptualises childhood, ${ }^{24}$ and enforces its conceptualisations on children and adults alike. ${ }^{25}$ Despite changes in the image of childhood and in jurisprudence concerning children, which will be discussed in chapter one in more details, the image of children as developing human beings, which is also known as the 'human becomings' approach, ${ }^{26}$ has always prevailed. I will argue that this image led to the creation of the child's right to development in international law, and to large extent has dictated the interpretation of this right.

The 'human becomings' conception of childhood describes children as passive actors, lacking agency, weak, vulnerable, and in need of protection. ${ }^{27}$ It positions childhood and children

\footnotetext{
18 James and James, supra n. 11, 70-74. On childhood and 'time' see Judith Ennew, 'Time for Children or Time for Adults?' in Jens Qvortrup et al (eds) Childhood Matters (Ashgate, Farnham 1994) 125-134.

${ }^{19}$ Colin Heywood, History of Childhood (Polity Press, London 2001); Shanahan, ibid, 413.

${ }^{20}$ Cynthia Price Cohen, 'Natural Law and Legal Positivism' in Michael Freeman and Philip Veerman (eds) The Ideologies of Children's Rights (Martinus Nijhoff Publishers, Dordrecht 1992) 53-70; Peter O. King, 'Thomas Hobbes's Children' in Susan T. Turner and Gareth B. Matthews (eds) The Philosopher's Child (University of Rochester Press, Rochester 1998) 65-84; For a claim that no conclusive conclusions can be drawn from Lock's writing about children see David Archard, 'John Locke's Children' in Susan T. Turner and Gareth B. Matthew (eds) The Philosopher's Child (University of Rochester Press, Rochester 1998) 85-104.

${ }^{21}$ Peter N. Stearns, 'Defining Happy Childhoods: Assessing a Recent Change' (2010) 3 Journal of the History of Childhood and Youth 165; Paula Fass, The Damned and the Beuatiful - American Youth in the 1920's (Oxford University Press, Oxford 1977) 15.

22 James and James, 2004, supra n. 11; Emily Buss, 'What The Law Should (And Should Not) Learn From Child Development Research' (2009-2010) 38 Hofstra Law Review 13.

${ }^{23}$ Michael King and Christine Piper, How the Law Thinks About Children (Gower, Vermont 1990) 36-37.

24 James and James, 2004, supra n. 11, 64-70.

${ }^{25}$ Ibid, 214.

${ }^{26}$ Lee, supra n. 6, 8 .

${ }^{27}$ For a non-Western perspectives see, for example, Charles Stafford, The Roads of Chinese Childhood (Cambridge University Press, Cambridge 1995); Toshiko Ito, 'New Education For Underprivileged Children: The Condition of Children's Rights in Japanese Law' (2012) 48 Paedagogica Historica 153; See also Robert A. LeVine and Rebecca S. New, Anthropology and Child Development (Blackwell Publishing, Malden, Massacusets and Oxford 2008).
} 
against adulthood and adults, describes childhood as 'the absence of adult qualities' ${ }^{28}$ Children are seen as 'unfinished product', ${ }^{29}$ and as human beings in making. Therefore, the aim of childhood is to be a 'journey toward a destination'. ${ }^{30}$ As James and Prout put it, childhood is 'a highly complex and engineered trajectory towards adulthood'. 31

Since the late nineteenth century, developmental psychology dominated, and to some extent dictated, the social and legal attitudes towards children. ${ }^{32}$ Developmental psychology was the 'key cultural arena, in which evolutionary and biologising ideas [were] replayed and legitimised $^{33}$ this attitude towards children. Developmental psychology divides childhood into sequential developmental stages, where the child moves from one developmental stage to the next, from being incompetent to competent, gradually learning the necessary skills to 'achieve the fully social state of adulthood' ${ }^{34}$ Developmental psychology includes wide range of theories, some were, or still are, more influential than the others. Sigmund Freud, for example, focused on sexual development, while Erik Erikson emphasized psychosocial development. Jean Piaget's theory of cognitive development probably had the most significant influence on law and on the legal discourse about children's capacities. ${ }^{35} \mathrm{Lev}$ Vygotsky's description of proximal development and the child's process of transforming into a healthy adult is also known for its influence on law, ${ }^{36}$ and on childhood studies. ${ }^{37}$

The prominence of these European-US centric theories has been widely challenged, ${ }^{38}$ and their cultural, gender ${ }^{39}$ and class biases ${ }^{40}$ have been highlighted. According to Michael Wyness, for example, the combination of the child's biological growth and psychology makes it 'difficult for us to view childhood any differently' ${ }^{41}$ Therefore, and despite its

\footnotetext{
${ }^{28}$ David Archard, Children: Rights and Childhood (Routledge, London 1993) 36.

${ }^{29}$ Carol Smart et al, The Changing Experience of Childhood (Polity, Cambridge 2001) 1.

${ }^{30}$ Lee, supra n. 6, 8 .

31 James and Prout, supra n. 7, 226

${ }^{32}$ Lloyd deMause, 'The Evolution of Childhood', in Lloyd deMause (ed) The History of Childhood (Souvenir Press, London 1976) 1-74.

33 Burman, Deconstructing Development Psychology,supra n. 15, 20-21.

34 Smart et al, supra n. 29, 4.

35 Buss, supra n. 22, 48-50.

${ }^{36}$ Buss, supra n. 22; Woodhead, Early Childhood Development, supra n. 4

37 Buss, supra n. 22.

38 Erica Burman, 'Deconstructing Neoliberal Childhood: Towards a Feminist Antipsychological Approach' (2012) Childhood (Published online 17 May 2012) 2. See also Alison Diduck, Law's Families (LexisNexis London 2003) 74-77.

${ }^{39}$ Carol Gilligan, In a Different Voice (Harvard University Press, Cambridge, Massachusetts 1982).

${ }^{40}$ Burman, Deconstructing Development Psychology, supra n. 15,18-19.

${ }^{41}$ Michael Wyness, Childhood and Society (Palgrave, Basingstoke 2006) 18.
} 
theoretical and conceptual shortcomings, developmental psychology still dominates childhood studies and has significant influence on law, particularly international children's rights law. As this thesis argues, international children's rights law is entrenched with the view of the 'developing child', focusing on the fact that children do grow up, while ignoring the social and moral characteristic attached to the process of maturation.

The 'human becomings' approach enjoys prominence in other disciplines as well, and it is not only developmental psychology that promotes it. Arguably the best example of its integral place in Western culture is to be found in Ěmile Durkheim's article on education, published in 1911:

'The essential function of this age, the role and purpose assigned to it in nature, may be summed in a single word: it is the period of growth. That is to say, the period in which the individual, in both the physical and moral sense, does not yet exist, the period in which he is made, develops and is formed... in everything the child is characterized by the very instability of his nature, which is the law of growth'. ${ }^{42}$

Durkheim could not have expressed it more clearly: the child does not yet exist as an individual with an agency, and the 'law of growth' should therefore govern childhood and dictate the treatment of children. The 'law of growth' and the 'human becomings' approach were also used in anthropology. The first major research to study the lives of children was Margaret Mead Coming of Age in Samoa, published in $1928 .{ }^{43}$ Mead observed the maturation process of girls, from childhood to adulthood, thus perpetuating the idea that the importance of children's lives lies in what the future holds for children. ${ }^{44}$ Growing up in Samoa led to the establishment of the Culture and Personality School of anthropology, ${ }^{45}$ where anthropologists and developmental psychologists teamed up under the umbrella of the Culture and Personality School, to study the ways in which "children became adults'. ${ }^{46}$ Another important anthropological study that was published around the same time is Katherine Bridges'sThe

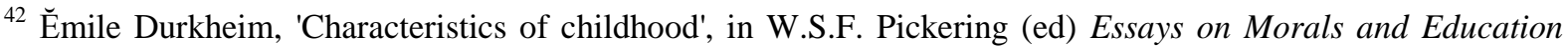
(translated into English by H.L. Sutchliffe, Routledge, London 1979. First published in 1911) 150. Emphasis in the original.

43 Margaret Mead, Coming of Age in Samoa: A Psychological Study of Primitive Youth for Western Civilisation (Harmondsworth, Penguin Books 1943. First published in 1928).

${ }^{44}$ For a critique on Mead's work see Derek Freeman, Margaret Mean and Samoa: The Making and Unmaking of an Anthropological Myth (Harvard University Press, Cambridge and London 1983).

45 Heather Montgomery, An Introduction to Childhood (Wiley Blackwell, Chichester 2009) 22-23.

${ }^{46}$ Ibid, 23.
} 
Social and Emotional Development of the Pre-School Child.$^{47}$ This research, which was described by the Lancetas one of the most influential studies on children's lives and behaviour, ${ }^{48}$ observed the daily lives of children in the classroom and the playground, in order to develop a 'development scale' of the infant. ${ }^{49}$

After World War I, one of the main projects of childhood studies was to define the 'normal' and 'abnormal' child, ${ }^{50}$ and to understand how children's lives, bodies and minds should be treated. ${ }^{51}$ Dozens of different manuals explaining to parents how to raise their children were published in the UK. By using medical and psychological jargons to delineate, for example, how to raise a 'healthy child', ${ }^{52}$ these guides are good examples of the centrality of the care for the child's future in Western culture.

Children's development was the subject of numerous other studies, including research about children's play and development, language and development, social bond and development, brain development, bodily development, sexual development, cognitive development, biosocial development and others. ${ }^{53}$ These studies attempt to 'reveal' how children develop, what factors have positive or negative influences on their development, what qualifies as 'good' development, and what is considered as a disability. The findings and conclusions of these studies are of little significance in the context of this thesis; what concern me is their volume and the diverse meanings of 'children's development', which they use. The colossal corpus of literature is evidence of the totality of the conception of children as 'human becomings', which hinders most efforts to understand children and childhood in any other way. As John Modell rightly noted, the history of childhood is written from a developmental perspective ${ }^{54}$ Childhood, therefore, seems to be important only in terms of the child's

\footnotetext{
${ }^{47}$ Katharine M. Banham Bridges, The Social and Emotional Development of the Pre-School Child (Kegan Paul, Trench, Trubner\&Co, London 1931).

48 Anonymous note, 'The Development of Young Children' (1931) 668 The Lancet.

${ }^{49}$ See also Levine and New, supra n. 27.

50 André Turmel, A Historical Sociology of Childhood: Developmental Thinking, Categorization and Graphic Visualisation (Cambridge University Press, Cambridge 2008); See also Helga Kelle, "Age Appropriate Development' As Measure and Norm' (2010) 17 Childhood 9.

51 For a good review on this point see Annemike van Drenth and Kevin Myers, 'Normalising Childhood: Politics and Interventions Concerning Special Children in the United States and Europe (1900-1960)' (2011) 47 Paedagogica Historica 719.

52 John Stewart, "'The Dangerous Age of Childhood": Child Guidance and the "Normal" Child in Great Britain, 1920-1950’ (2011) 47 Paedagogica Historica 785.

53 See Brian Hopkins (ed), The Cambridge Encyclopedia of Child Development (Cambridge University Press, Cambridge 2005); Kathleen Stassen Berger, The Developing Person ( $7^{\text {th }}$ edition, Worth Publishers, New York 2006).

54 John Modell, 'How May Children's Development be Seen Historically?' (2000) 7 Childhood 81.
} 
future ${ }^{55}$ This perception reflects the common idea, or 'desire', ${ }^{56}$ that children simply 'grow up' 57 'Development', then, is not only a hypothesis, but also the prognosis of childhood. It is therefore clear why according to this paradigm of childhood, 'children didn't have rights' ${ }^{58}$ As persons in making, children were subjects to the 'law of growth' and not to human rights law.

While the term 'children's development' is often used, we need to note that it does not have a unified, common and universal meaning. As Brian Hopkins writes in The Cambridge Encyclopaedia of Child Development:

'take any textbook on human development and then look for whether it provides a definition of 'development'. You will probably find that such a definition is absent or that it provides in a couple on unenlightening sentences. In fact, most of these textbooks provide only a cursory definition of the term. The reason is not hard to find: development is one of those terms that we freely use in everyday language and yet when we try to pin it down with a precise definition it assumes an almost evanescent-like quality'. ${ }^{9}$

A new conception of childhood, the 'human beings' concept, emerges in the $1970 \mathrm{~s},{ }^{60}$ embracing diverse and complex notions of childhood. ${ }^{61}$ According to the 'human beings' approach, children are perceived as persons and not as 'projects', ${ }^{62}$ and the study of childhood should therefore be done independently, without comparing children to adults. ${ }^{63}$ Children are perceived as active human beings who should participate in shaping their own lives, and have an active role in their communities. ${ }^{64}$ According to this view, children's agency should be respected and their voices should be heard. ${ }^{65}$

\footnotetext{
55 Allison James and Alan Prout, 'Re-presenting Childhood: Time and Transition in the Study of Childhood' in James and Prout, supra n. 7, 230-250, 239.

56 Erica Burman, 'Desiring Development? Psychoanalytic Contribution to Antidevelopmental Psychology' (2011) 24 International Journal of Qualitative Studies in Education 1, 9.

${ }^{57}$ Allison James et al, Theorizing Childhood (Polity, Cambridge 1998) 196. See also Onora O’Neill, 'Children's Rights and Children's Lives' (1988) 98 Ethics 445.

58 Michael Freeman, 'The Human Rights of Children' (2010) 63 Current Legal Problems 1, 9.

59 Brian Hopkins, 'What is Ontogenetic Development?' in Brian Hopkins (ed) The Cambridge Encyclopedia of Child Development, supra n. 53, 18-24, 18.

${ }^{60}$ Karen Wells, Childhood in a Global Perspective (Polity Press, Cambridge 2009) 1-24.

61 Alan Prout, The Future Of Childhood (Routledge, London 2005) 7-34; Prout and James, 'A New Paradigm for the Sociology of Childhood? Provenance, Promise and Problems', supra n. 7, 7-33.

62 Smart et al, supra n. 29, 13.

63 James and Prout, Constructing and Reconstructing Childhood, supra n. 7, 8. See also Berry Mayall, Towards a Sociology of Childhood: Thinking From Children's Lives (Open University Press, Gosport 2002) 33.

64 James and James, supra n. 11, 38-39.

65 James and Prout, supra n. 7, 8.
} 
Recognising children's agency is, as Allison James argues, probably 'the most important theoretical contribution of this conception to childhood studies' ${ }^{66}$ Recognising children as social agents means that children are being seen as part of the social structure, and that their active role in it is respected. ${ }^{67}$ As human 'beings', children are defined based on their own rights, ${ }^{68}$ and not by comparison to adults. It also means that they are considered as human rights holders. ${ }^{69}$ As Michael Freeman argues, those who have human rights "can exercise agency... as agents, rights bearers can participate. They can make their own lives, rather than having their lives made for them' ${ }^{70}$

An important implication of recognising children's agency is the realisation that children should be listenand consulted with, and that their opinions and voices should be heard and taken into consideration. This idea is reflected in Article 12 of the Convention, which protects the child's right to participation. ${ }^{71}$ When one listens to children, one realises just how much children know about their lives and about their world. Children make sense of their own experience of poverty (and what qualifies as well-being), ${ }^{72}$ of living on the street, ${ }^{73}$ of their health and the implications of dying, ${ }^{74}$ what human rights means, ${ }^{75}$ and how the UN Convention on the Rights of the Child should be interpreted. ${ }^{76}$ If asked, children can articulate just how much their relationship with friends and family members affects their

\footnotetext{
${ }^{66}$ Allison James, 'Agency', in Palgrave Handbook of Childhood Studies, supra n. 1, 34-45, 34.

${ }^{67}$ Ibid, 38-40.

${ }^{68}$ Lee, supra n. 6, 54

${ }^{69}$ Michael Freeman, The Moral Status of Children (Martinus Nijhoff Publishers, The Hague 1997).

${ }^{70}$ Michael Freeman, 'Why It Remains Important to Take Children's Rights Seriously' (2007) 15 International Journal of Children's Rights 5, 8 .

${ }^{71}$ For an analysis of Article 12 see Laura Lundy, 'Voice' is not enough: Conceptualising Article 12 of the UN Convention on the Rights of the Child' (2007) 33 British Educational Research Journal 927.

${ }^{72}$ Laura Camfield et al, 'What's the Use of 'Well-Being' in Contexts of Child Poverty? Approaches to Research, Monitoring and Children's Participation' (2009) 17 International Journal of Children's Rights 65; Haridhan Goswami, 'Social Relationships and Children's Subjective Well-Being' (2011) Social Indicator Research Online First 26.5.2011; Zoran Pavlovic and Tina Rutar Leban, 'Children's Rights International Study Project (CRISP) - A Shift from the Focus on Children's Rights to a Quality of Life Assessment Instrument' (2009) 2 Child Indicators Research 265.

73 Udi Mandel Butler, 'Freedom, Revolt and 'Citizenship' (2009) 16 Childhood 11; See also Marcela Raffaelli, 'How Do Brazilian Street Youth Experience 'the Street'?' (2001) 8 Childhood 396.

${ }^{74}$ Myra Bluebond-Langer, The Private Worlds of Dying Children (Princeton University Press, Princeton 1978) 5.

75 Martin D. Ruck et al, 'Children's and Adolescents' Understanding of Rights: Balancing Nurturance and SelfDetermination' (1988) 64 Child Development 404; Martin D. Ruck et al, 'Adolescents' and Children's Knowledge About Their Rights: Some Evidence For How Young People View Rights In Their Own Lives' (1998) 21 Journal of Adolescence 275.

${ }^{76}$ Wiebina Heesterman, 'An Assessment of the Impact of Youth Submission on the United Nations Committee on the Rights of the Child' (2005) 13 International Journal of Children's Rights 351.
} 
happiness and feeling of 'well-being' ${ }^{77}$ If listened to, children can express their own point of view about their own development. Children distinguish between the progression of development and the aims it should achieve. They recognise 'development' with a sense of direction in life, and what they see as the natural process of maturation. Perceiving 'development' as a natural process, according to Helga Kelle, means that the notion of getting older 'can hardly be seen as a personal achievement' ${ }^{78}$

Children's ability to make sense of the world around them is not only a characteristic of adolescence, but as Priscilla Alderson et al have shown, also premature babies can do it. ${ }^{79}$ Therefore, children's participation is not necessarily an issue of children's capacities to articulate their wishes and preference, but also the space that they have to do so, and the willingness of adults to listen to them. Needless to say, it is not always easy to facilitate children's participation and decision-making, and there are numerous methodological and structural problems in doing so. ${ }^{80}$ But problems in implementation should not undermine the foundations of the principle and its pursuit. 'Seeing children as subject of capabilities means that we can consider them endowed with agency and autonomy, able to express their points of view, values and priorities. ${ }^{81}$ The importance and implications of respecting children's agency and voice in the context of the right to development will be discussed throughout the thesis, especially in chapters five and six.

Despite the paradigm shift towards 'being', the primary concern with respect to children remains, to a large extent, focused on their development and growth. Not least because, as Burman noted, 'we cannot 'unthink' development' ${ }^{82}$ As chapter two argues, this background led to the creation of the right to development in international children's rights law.

\footnotetext{
77 Haridhan Goswami, 'Social Relationships and Children's Subjective Well-Being' (2011) Social Indicator Research online 26.5.2011.

78 Helga Kella, 'The Discourse of 'Development' - How 9 to 12-Year-Old Children Construct 'Childish' and 'Future Development' Identified Within Their Peer Culture' (2001) 8 Childhood 95, 109; In a different context see Richard Maclure, 'The Dynamics of Youth Participation: Insights from Research Fieldwork with Female Youth in Senegal' in Myriam Denov et al (eds) Children's Rights and International Development (Palgrave, New York 2011) 155-174.

79 Priscilla Alderson et al, 'The Participation Rights of Premature Babies' (2005) 13 International Journal of Children's Rights 31.

${ }^{80}$ Sally Holland et at, 'Power, Agency and Participatory Agenda: A Critical Exploration of Young's People's Engagement in Participative Qualitative Research' (2010) 17 Childhood 360.

81 Jérôme Ballet et al, 'Children Agency and the Capability Approach - A Conceptual Framework' in Mario Biggeri et al (eds) Children and the Capability Approach (Palgrave Macmillan, Basingstoke 2011) 22-46, 22.

82 Burman, 'Desiring Development? Psychoanalytic Contribution to Antidevelopmental Psychology', supra n. $56,13-15$.
} 
Another issue that should be considered is the universality, or not, of childhood, especially the universality of 'children's development'. Traditionally, the concept of childhood embraced a universal image of childhood in general, and of child's development in particular. ${ }^{83}$ It was the influence of Euro-American developmental psychology that led to the belief that all children, regardless of their identity, personality, ethnicity, gender, or society that they are living in, should develop in similar ways. ${ }^{84}$ Childhood was seen as a coherent, nuance-free, concept. As such, the universal child was also a standardised child. This universal child represents an a-historical model of 'the child', which, according to James, is mostly vested in the notion of bodily development. ${ }^{85}$ Recent attempts made by the new sociology of childhood and new approaches to developmental psychology (such as cultural psychology $)^{86}$ have challenged this perception. But the moral-political assumptions that underpin traditional developmental psychology have yet to be substantially undermined. ${ }^{87}$ Smart at el claimed that 'once the social nature of childhood was recognised, it became possible to think beyond the developmental/socialization framework for understanding children ${ }^{88}$ Burman disagrees with this proposition, claiming that contemporary children's rights and childhood discourses represent and consolidate traditional gendered, racialized and psychologized views. ${ }^{89}$ The latter argument not only explains the background for creating the child's right to development by the UN Convention on the Rights of the Child, but also, as the thesis argues, the ways in which this right has been interpreted.

I argue that although the Convention accommodates both conceptions of childhood, ${ }^{90}$ insofar the child's right to development, the Convention holds the view that there is one appropriate way for a child to develop. ${ }^{91}$ As a result, the right to development is understood to provide an un-distinguishable protection for the same 'development' to all children. The thesis

\footnotetext{
83 Martin Woodhead, 'Reconstructing Developmental Psychology - Some First Steps' (1999) 13 Children \& Society 3, 5-6.

${ }^{84}$ Ibid, 8-9.

85 Allison James, 'The Standardized Child: Issues of Openness, Objectivity and Agency in Promoting Childhood Health' (2004) 13 Anthropological Journal on European Culture 93.

${ }^{86}$ Woodhead, 'Reconstructing Developmental Psychology - Some First Steps', supra n. 83, 9-12.

${ }^{87}$ Burman, Deconstructing Development Psychology,supra n. 15, 298.

${ }^{88}$ Smart et al, supra n. 29, 12.

${ }^{89}$ Burman, 'Deconstructing Neoliberal Childhood: Towards a Feminist Antipsychological Approach', supra n. 38,1 .

90 Freeman, The Human Rights of Children, supra n. 58, 11-12.

91 Ashleigh Barnes, 'CRC's Performance of the Child as Developing' in Michael Freeman (ed) Law and Childhood Studies (Oxford University Press, Oxford 2012) 392-418.
} 
challenges these premises and offers a different, context-sensitive framework that respects children's agency and embraces a broad definition of 'children's development'. 


\section{Chapter One:Embedding the Concept of 'Children's Development' into International Children's Rights Law}

'The child is given rights so that he may become a complete and perfect human being' (Cuevas Cancino,the Rapporteur of the Drafting Committee on the Declaration on the Rights of the Child, 1959) ${ }^{1}$

'Children are not the people of tomorrow, but are people of today. They have a right to be taken seriously, and to be treated with tenderness and respect. They should be allowed to grow into whoever they were meant to be - the unknown person inside each of them is our hope for the future' (Janusz Korczak, educator, 1927) $^{2}$

\section{$\underline{\text { Introduction }}$}

This chapter studies the embodiment of the 'human becomings' conception of childhood in international children's rights law, focusing on the process of embedding protection for children's development. Chronologically, the chapter begins at the last quarter of the $19^{\text {th }}$ century and ends in 1978, with the introduction of a draft for an international convention on children's rights. I argue that despite changing attitudes toward children and children's legal status that occurred over a period of 100 years, the desire to protect what Western society considers the essence of children's existence has prevailed. Consequently, international children's human rights law was created with the ultimate aim of protectingchildren's journey toward adulthood.This chapter is not a study of the history of international children's rights law in general, but an introduction to the events and processes that led to the creation of the child's human right to development in international children's rights law.

At the turn of the $20^{\text {th }}$ century, the Western conception of childhood underwent significant changes. Gradually, children began to be perceived as a source of pleasure for their parents, rather than as a burden or a mouth to feed. Children were also seen as a potential skilled labour force, and therefore, it made sense to investin their future. Society therefore began to take an interest, and to protect, children's growth, particularly with respect to education and

\footnotetext{
${ }^{1}$ UNHCHR, Legislative History of the Convention on the Rights of the Child, Volume I (New York and Geneva 2007) 21.

${ }^{2}$ Janusz Korczak, The Child's Right to Respect(Council of Europe, Brussels 2009. Originally published in 1927) 18-19.
} 
health. ${ }^{3}$ These new attitudes resulted in new domestic legislation concerning the promotion of children's welfare. On the international law level, similar changes occurred a few decades later. The First World War and its aftermath led the international community to embrace a new perspective regarding children. In 1924, the League of Nations adopted the Declaration on the Rights of the Child, ${ }^{4}$ the first international legal instrument dedicated solely to the human rights of children, which continues to inspire the interpretation of children's rights today. ${ }^{5}$ The Declaration pinned down 'children's development' as a key concept in international children's rights law and the chapter analyses its meaning and importance in detail. The chapter presents the work of three scholars: Janusz Korczak, Ellen Key and Eglantyne Jebb, who worked at the beginning of the $20^{\text {th }}$ century, and in different ways contested the prevailing welfare paradigm.

After establishing the foundations of international children's rights law, the chapter discusses the second international legal instrument that acknowledges children's rights: the 1959 UN Declaration on the Rights of the Child. This Declaration is much broader in scope than the 1924 Declaration and includes many additional rights of children. Like the 1924 Declaration, the 1959 Declaration embraces protection for children's development, and links some of the Declaration's rights to support this end.

The chapter then describes the changes in international human rights law that occurred during the 1960's, and the rise of the child liberation movementin the 1970's. The liberation movement's key argument was that children should be seen as equal to adults, and therefore, be recognised as human rights holders in the same way that adults are. The liberationists challenged the developmental model and its assumptions concerning children's capacities, arguing that society's attitude towards children must change, and that relationships between children and their parents, teachers and governments should be re-defined. The end of the 1970's marked the resurrection of a new era in international children's rights law, as the UN declared 1979 as the International Year of the Child, and the government of Poland

\footnotetext{
${ }^{3}$ Priscilla Robertson, 'Home as a Nest: Middle Class Childhood in Nineteenth-Century Europe'in Lloyd deMause (ed) The History of Childhood (Souvenir Press, London 1976) 407-431, 407.

${ }^{4}$ The term 'law' refers also to what is known as 'soft law' in international law. Although the 1924 Declaration on the Rights of the Child is not a binding international treaty, it nevertheless has a normative significance in international law. Christine Chinkin, 'The Challenges of Soft Law: Development and Change in International law' (1989) 28 International and Comparative Law Quarterly 850.

5 Dominique Marshall, 'The Construction of Children as an Object On International Relations: the Declaration of Children's Rights and the Child Welfare Committee of League of Nations, 1990-1924' 7 (1999) International Journal of Children's Rights 103, 104.
} 
introduced the first draft of an international convention for the rights of the child. This draft for the Convention on the Rights of the Child will be the departing point for the next chapter.

\section{The $19^{\text {th }}$ Century and Children's Welfare Laws}

The last quarter of the $19^{\text {th }}$ century marked a period of significant economic, social,political and legal changes in the West, all of which had an impact on the development of the concept of childhood. The perception of children as their father's property began to fade away, and children began to be perceived as human beings. ${ }^{6}$ The notion of 'purity' replaced the previous concept of 'sin', 7 and children were no longer seen as 'little devils,' but rather as innocent creatures with no intention of doing harm. These kind of changes informed the development of the care for children's welfare, which not only humanized children, but also 'more explicitly victimized ${ }^{8}$ them.

Society embraced the idea that parents, educators and the government should ensure children's welfare, mainly by protecting children from illness ${ }^{9}$ and from the hardships of poverty. ${ }^{10}$ Declining birth mortality rates, capitalism, consumerismand new advertising techniques injected happiness into childhood, ${ }^{11}$ leading parents to 'plea for cheerfulness'. ${ }^{12}$ Mothershavebegun to believe that they could turn their children into 'happy and productive citizens'. ${ }^{13}$

The increasing need for skilled workers and rising recognition of the importance of nutrition and personal hygiene ${ }^{14}$ led to the introduction of compulsory education. Schools ceased to be a place where only children from wealthy families gained education, and transformed into social institutions that were designed to create skilled and healthy workers. ${ }^{15}$ Combating child

\footnotetext{
${ }^{6}$ For a review of the evolution in attitudes to children see Michael Freeman, The Rights and Wrongs of Children (Frances Pinter, London 1983) 13-19.

${ }^{7}$ Karen Sanchez Eppler, Dependent States: The Child's Part in Nineteenth-Century American Culture (University of Chicago Press, Chicago 2005) XV; David Archard, Children: Rights and Childhood (2 ${ }^{\text {nd }}$ edition Routledge, London 2004).

${ }^{8}$ Paula S. Fass, 'A Historical Context for the United Nations Convention on the Rights of the Child' (2011) 633 ANNALS 17, 22.

${ }^{9}$ Mary Ann Mason, From Father's Property to Children's Rights - The History of Child Custody in the United States (Columbia University Press, New York 1994) 87-92.

${ }^{10}$ Robert L. Geiser, 'The Rights of Children' (1976-1977) 28 Hastings Law Journal 1027, 1028-1034.

${ }^{11}$ Peter N. Stearns, 'Defining Happy Childhoods: Assessing a Recent Change' (2010) 3 Journal of the History of Childhood and Youth 165.

${ }^{12}$ Ibid.

${ }^{13}$ Fass, 'A Historical Context for the United Nations Convention on the Rights of the Child', supra n. 8, 21.

${ }^{14}$ Ibid, 19-22.

${ }^{15}$ Mary Jo Maynes, Schooling in Western Europe (State University of New York Press, Albany 1985).
} 
labour and creating the practical conditions (and obligation) for parents to send their children to school led to setting a bar for a minimum working age and limited working hours. ${ }^{16}$

The rise of the idea of the State acting as Parens Patriae made it easier to introduce legislation to combat child abuse. ${ }^{17}$ Such legislation did not only impose social norms concerning child rearing on parents, but also enabled states to interfere (and in cases of serious abuse, created a dutyto interfere) with the family unit and remove children from parental custody. Parents, who did not follow and practise the changing views of childhood, either because they were unwilling or incapable of adapting to the new middle-class ideal, were subject to these new provisions.In England, the 1847 Larceny Act and the 1854 the Reformatory School Act are two examples of this new perception. ${ }^{18}$ In the United States, the establishment of the first juvenile court in the State of Illinois in 1899 was another important benchmark, since it represented the obligation of the state to 'aid and protection and to direct him into a path that leads to good citizenship' ${ }^{19}$

These changes in law supported this conception of childhood as a 'time of happiness' for children and families alike. ${ }^{20}$ Mary Ann Mason claims that this new social trendultimately aimed at facilitatingchildren's process of growing up and transforming children into citizens. ${ }^{21}$ However, from a child's perspective, the message society sent might be seenless obvious.

'The young are told to work hard and value school, but also to enjoy themselves. They are to be innocent but also sexually alluring. They are to be respectful and obedient, but also independent consumer beholden to no one. They are to be youthful but not childish. The basic contradiction is that the young are told to grow up fast, but also that they needn't grow up at all, at least not until they reach their late twenties or early thirties'. ${ }^{22}$

\footnotetext{
${ }^{16}$ C.R. Margolin, 'Salvation Versus Liberation: The Movement For Children's Rights in A Historical Context' (1977-1978) 25 Social Problems 441, 443-445.

${ }^{17}$ Geiser, supra n. 10, 1030; Rex and Wendy Stainton Rogers, Stories of Childhood (University of Toronto Press, Toronto 1992) 22-24.

${ }^{18}$ Freeman, Rights and Wrongs of Children, supra n.6, 66-67.

${ }^{19}$ As quoted in Margolin, supra n. 16 443. See also Anthony M. Platt, The Child Savers - The Innovation of Delinquency ( $2^{\text {nd }}$ edition, The University of Chicago Press, Chicago 1977) 101-136.

${ }^{20}$ Paula S. Fass, The Damned and the Beautiful - American Youth in the 1920's (Oxford University Press, Oxford 1977) 15.

${ }^{21}$ Mason, supra n. 9, 85-120.

${ }^{22}$ Steven Mintz, Huck's Raft - A History of American Childhood (Harvard University Press, Cambridge 2004) 381.
} 
Nonetheless, children were generally not perceived as human rights holders. It was the care for children's welfare, rather than human rights, that was an important feature of law. ${ }^{23}$ Like women, people of colour and other minorities, children were still discriminated against and deprived of their basic human rights. Little, if any, attention or significance was givento their life as children, rather than as future adults. ${ }^{24}$

As dominant as the voices calling to care for children's welfare were at the end of the $19^{\text {th }}$ century and the beginning of the $20^{\text {th }}$ century, other voices on children and childhood were being expressed. With different biographical backgrounds and careers, Ellen Key (18481926), Janusz Korczak (1878-1942) and Eglantyne Jebb (1876-1928), the three pioneers, as Veerman described them, ${ }^{25}$ introduced fresh approaches towards childhood, children and their rights. These three authors respected children not for the adults that they could become, but for the children that they are, and therefore asked us to respect children as human rights holders. Their illuminating approaches deserve to be discussed in detail.

\section{Ellen Key}

In 1900, Ellen Key, a Swedish teacher, published The Century of the Child. ${ }^{26}$ This book is a manifesto that calls upon society to place children at the centre of attention, and to make some radical changes in social policies that relate to children, including marriage laws and the education system. ${ }^{27}$ Summarising the book in today's terms, it is evident that Key's goal was to promote the acknowledgement of children's agency and children as human rights holders. Nonetheless, Key did not settle with making a general claim in favour of recognising children's rights, and offered a list of these rights. On top of the list was the child's right to choose her or his parents. The right to education, the right to participation in the education

\footnotetext{
${ }^{23}$ Fass, The Damned and the Beautiful - American Youth in the 1920's,supra n. 20, 23.

24 Nonetheless, it should be noted that the welfare legislation concerning children is part of the process of recognizing children's citizenship. Bryan Turner, 'Personhood and Citizenship' (1986) 3 Theory Culture Society 1, 8-10.

${ }^{25}$ Philip E. Veerman, The Rights of the Child and the Changing Image of Childhood (Martinus Nijhoff Publishers, Leiden 1992) 73.

${ }^{26}$ Ellen Key, The Century of the Child (G.P. Putnam's Sons, New York and London 1909). On the influence of this book see Kriste Lindenmeyer and Bengt Sandin, 'National Citizenship and Early Policies Shaping 'The Century of the Child' in Sweden and the United States' (2008) 1 Journal of History of Childhood and Youth 50. For overall appreciation of Key's influence on the $20^{\text {th }}$ century see Jeroen J.J. Dekker, 'The Century of the Child Revisited' (2000) 8 International Journal of Children's Rights 133.

${ }^{27}$ The book was translated into English in 1909. At the same year, US President Theodore Roosevelt called the first White House conference on Children, which dealt with 'care of dependent children'. Beck Rochelle, 'White House Conferences on Children: an Historical Perspective' (1973) 43 Harvard Educational Review 653.
} 
process, the right to have a home, the right to be free from religious instructions, and the right to be free from labour followed.

In comparison with the common trends of her time, Key offered a different, less paternalistic perspective on children's lives. She touched upon the pressing issues of child abuse and schools, offering different approaches. For example, not only did Key call to put an end to child abuse, she also asked to remove the veil of privacy that covers the family unit, which to a very large extent, and despite new welfare acts, still shield families from external intervention. Key argued that respecting children's rights should not result in preventing only some acts of abuse, but rather in ending all forms of abuse, including corporal punishment in schools and by family members. ${ }^{28}$ Key also called for the elimination of the category of 'illegitimate children', arguing that the legal definition of the relationship between the child's parents should not define the status of the child. ${ }^{29}$

Schools and education were subjects of grave concern for Key. She asserted that school has no other purpose but 'to give to each separate individual as much development and happiness as possible... the schools should be nothing but the mental dining-room in which parents and teachers prepare intellectual bills-of-fare suitable for every child' ${ }^{30}$ Key thought that at the early stages of their life, children should stay at home and be educated by their mothers. They should be able to go to school only at the age of primary education, but so long as their souls would not 'murdered' by their teachers. ${ }^{31}$ In contemporary vocabulary, it can be argued that Key set the ground for respecting children's right to education.

Despite the innovation of her work, to some extent Key also held the views that 'the child' is an innocent, somewhat naïve, human being. This approach is best demonstrated when she criticises common educational methods:

'to bring up a child means carting one's soul in one's hand, setting one's feet on a narrow path; it means never placing ourselves in danger of meeting the cold look on the part of the child that tells us without words that he finds us insufficient and unreliable. ${ }^{32}$

\footnotetext{
${ }^{28}$ Key, supra n. 26, 128-138.

${ }^{29}$ Ibid, 44-45.

${ }^{30}$ Ibid, 207.

${ }^{31}$ Ibid, 203-232.

${ }^{32}$ Ibid, 114.
} 
Furthermore, like Jean-Jacques Rousseau's approach toward children as expressed in Emile, ${ }^{33}$ and to the 'salvation' discourse, Key sought to save children's souls from those who would try to 'master' their thoughts. ${ }^{34}$

Much of Key's arguments were devoted to the question of child rearing and the process of growing up. Echoing the tendency to rely on life science and psychology, Key called for the establishment of a 'pedagogical culinary science' that would determine what children should learn. ${ }^{35}$ In describing the objective of this science, Key invented what would become the basic norm of international children's rights law in general and of the right to development in particular. According to Key, 'harmonious development is the finest result of man's training, but it is only to be attained by his own choice. It implies a harmony between the real capacities of the individual, not a harmony worked up from a pedagogical formula. ${ }^{36}$

Key's statement was ahead of its time. The term 'harmonious development' describes the optimum stage of development that the child should achieve. Probably more important is the recognition of the child's agency and voice as important factors in developing the child's own capacities, instead of the perception that these capacities will result from training. Yet, this quote resonates with the perception of a child that should develop her or his 'harmonic' nature, assuming the existence of a kind of coherent personality and good intentions. But as much as Key was concerned with the child's future ('human becomings'), she also advocated in favour of the importance of children's life as children ('human being'). Society, she argued, should 'allow children to live'. ${ }^{37}$

\section{$\underline{\text { Janusz Korczak }}$}

Janusz Korczak was a paediatrician and the director of the Jewish Orphanage Dom Sierot in Warsaw for thirty years, from 1912 until his murder in Treblinka on 6 August 1942. ${ }^{38}$ Korczak wrote a number of books wherein he spelled out his unique approach towards childhood and children's lives and rights. Korczak's profound conception of children's rights

\footnotetext{
33 Julia Simon, 'Jean-Jacques Rousseau's Children', in Susan M. Turner and Gareth B. Matthews (eds) The Philosopher's Child (University of Rochester Press, New York 1998) 105-120, 111.

${ }^{34}$ Key, supra n. 26, 110.

${ }^{35}$ Ibid, 256.

${ }^{36}$ Ibid. Emphasis added.

${ }^{37}$ Ibid, 241.

${ }^{38}$ Veerman, supra n. 25, 93; See also Irena Sendlerowa, 'I Saw Korczak and the Children Walking from the Ghetto to their Death' in Janusz Korczak's Legacy, supra n. 2, 43-45, 43.
} 
was the most advanced of his time, and to a large extent, might be considered 'radical' even today.

Korczak believed that children are 'complete' human beings, and not merely persons engaged in a process of becoming adults. As such, children's personhood should be acknowledged and their human rights respected. 'Our indolence keeps us from discovering beauty in the present', Korczak wrote, 'when I approach a child, I have two feelings: affection for what he is today and respect for what he can become'. ${ }^{39}$ Korczak did not like the tendency to characterize childhood using psychoanalysis jargon, arguing that Freud is a 'dangerous maniac' because he 'reduced childhood to a psychosexual stage'. ${ }^{40}$ According to Korczak, childhood is not a sequence of insignificant stages of the human life that ought to be accomplished in order for a child to be successfully transformed into an adult. On the contrary, Korczak sought to have children respected for being children, and not merely for being future adults. 'Is there a life that exists as some joke?' Korczak rhetorically asked. 'No, childhood years are long and important ones in the life of a man'. ${ }^{41}$

Unlike Key, Korczak did not only view education as a means of transforming knowledge, but rather as a process that ought to respect the child's dignity in a participatory way. Children, Korczak claimed, should take part in the educational process and should be given the space necessary to influence the content of education as well as the administration it carries with it. For these reasons, the orphanage he directed was self-governed. The children ran their own parliament, where they could debate and decide about many different issues concerning their lives. They had their own newspaper, as well as a court of peers where children and staff alike, including Korczak, could face trial if they broke the house's code.

In his seminal essay The Child Right to Respect, published in 1927, Korczak defines 'the child' and the time of 'childhood' in the following terms:

'The basic idea that the child is not now but will become later, does not know anything but will do so, is not capable of doing anything but will learn, makes us live in a perpetual state of expectation... For the sake of tomorrow we fail to respect what amuses, saddens, amazes, angers, and interests him today. For the sake of tomorrow, we steal many years of his life... ${ }^{42}$

\footnotetext{
${ }^{39}$ Janusz Korczak, Loving Every Child(Algonquin Books of Chapel Hill, North Carolina 2007) 17.

${ }^{40}$ As quoted in Betty Jean Lifton, The King of Children- A Biography of Janusz Korczak (Chatto \& Windus, London 1988) 125.

${ }^{41}$ Korczak, The Child's Right to Respect,supra n. 2, 33.

${ }^{42}$ Korczak, The Child's Right to Respect, supra n. 2, 18- 19.
} 
Korczak argued that society should stop overlooking children's experiences of the world, and respect and appreciate the importance of the time of childhood. The child should not be seen only as a future citizen, but as a person in the present. At the same time, Korczak does not suggest ignoring the fact that the child is growing up, claiming that this process should be celebrated, rather than be a reason for more suppression. 'We should have more respect for the mysteries and fluctuations of the hard business of growing up!', he adds, ${ }^{43}$ and warns us from being to anxious with the future.

'We search for signs of the future; we'd like to be able to foretell, to be certain; this anxious anticipation about what the future holds increases our indifference towards what it is'. ${ }^{44}$

In that sense, Korczak may have been the first to articulate the conception of the child as a human 'being' rather than as a human 'becoming'. But he does much more, as he refuses to use polarized definitions, asking to break the dichotomy between these two concepts. Korczak advocates for changing the model of childhood to a model that recognises children as human 'becoming' and human 'beings' simultaneously. In the last chapter I term this idea 'the hybrid conception of childhood', and suggest how to utilize it in order to analyse the child's right to development.

Korczak's scholarly work was primarily focused on social issues concerning children, but he also wrote about their legal status. Like Key, Korczak recognised the importance of having a human rights regime that protects children and, again like Key, suggested a list of these rights. 'I call for a Magna Charta Liberatatis concerning the Rights of the Child' ${ }^{45}$ This 'Magna Charta' can be established based on Korczak's book How to Love a Child, ${ }^{46}$ and it includes the following rights: ${ }^{47}$ the child's right to respect; the right to autonomy; the right to make mistakes; the right to fail the right to participate; the right to human dignity (which includes the right to die prematurely); the right to information; the right to privacy; the right to own property; the right to education; the right to belief and the right to resist any

\footnotetext{
${ }^{43}$ Korczak, Loving Every Child, supra n. 39, 63.

${ }^{44}$ Korczak, The Child's Right to Respect, supra n. 2, 24-25.

${ }^{45}$ As quoted in Gabriel Eichsteller, 'Janusz Korczak - His Legacy and its Relevance for Children's Rights Today' (2009) 17 International Journal of Children's Rights 377, 385.

${ }^{46}$ Janusz Korczak, 'How to Love a Child' in M. Wolins (ed) Selected works of Janusz Korczak (National Science Foundation, Washington D.C. 1967)355-356.

${ }^{47}$ Compare to Lifton, supra n. 40 ,
} 
educational influence; the right to due process and 'to a children's court'; the right to freedom of religion; the right to love; and the right to respect for her or his grief.

This list of rights does not aim merely to protect the welfare of the child or seek to prevent any harm to the child's ability to bloom as an adult.This list of rights, including the right to be loved by the child's parents, is much more comprehensive and progressive than most of the human rights instruments that existed at the time, including the 1924 Declaration on the Rights of the Child (which will be discussed later in this chapter), or any other 'general' human rights instrument in international law. This list presents a completely different approach towards children. Betty Lifton's reading of Korczak's work adds two rights to this list, on the bases of the following two quotations: "we demand: do away with hunger, cold, dampness, stench, overcrowding, overpopulation', and 'children are not people of tomorrow, they are people today'. Consequently, she named the first right 'the right to optimal conditions in which to grow and develop'. The second right is titled the right to 'live in the present'. ${ }^{48}$

These quotes reflect a dualism towards children that is rarely expressed by other authors, including most contemporary commentators. These quotes, and the rights that can be concluded from them, create a broad legal framework for caring for children's lives. Introducing the care for the child's future as an issue of human rights, the right to grow up and the right to live in the present are not mutually exclusive but rather complement each other. They represent a complex conception of childhood that results in acknowledging the right to development of children while defining the idea of 'development' in complicated terms.

\section{Eglantyne Jebb}

Eglantyne Jebb, an English teacher, made an enormous contribution to the creation of international children's rights law, though played a lesser role in developing its theoretical understanding. Her two main contributions were establishing the organization 'Save the Children', and drafting the League of Nations' Declaration on the Rights of the Child. ${ }^{49}$ Jebb was less interested with domestic policies. Following the First World War, Jebb thought that children should be protected from the mass killing, major traumas and other negative

\footnotetext{
${ }^{48}$ Korczak, How to Love a Child, supra n. 46, 355.

${ }^{49}$ See Clare Mulley, The Women who saved the Children (Oneworld, Oxford 2009).
} 
influences of wars. The famine that spread through Europe after the War, which affected children more than any other group in society, concerned her as well. Jebb thought that children, whom she described as innocent people who had nothing to do with the War generated by adults, should not suffer from the consequences of any future wars. Taking the somewhat naïve view that 'common people could not bear to see children die without at least trying to help', ${ }^{50}$ Jebb decided to establish 'Save the Children' as an organization that aims to provide relief for children all over the world. ${ }^{51}$ The name and aims of the organization perfectly reflect the Christian spirit of salvation, and the trend to 'save' children that inspired the dominant 'welfare' paradigm. ${ }^{52}$

Alongside her charity work, Jebb realised that the newly established League of Nationscould be used to providean international legal framework for the protection of children.

'The world's children stand in urgent need of better protection... They who pay the heaviest price for our short-sighted economic policies, our political blunders, our wars. Adults can pass through a period of stress and strain and perhaps be none the worst for it, once it is over, but if we fail to give children their physical requirements and we restrict their educational advantages, they may well be handicapped in consequences for the rest of their lives'.53

Jebb is mostly concerned with the effect of adults' 'short-sighted' views on children's 'physical requirements' and education, as they compromise children's future. Worrying that children could become 'handicapped' in the future, Jebb calledfor satisfying their needs in the present. Unlike Key or Korczak, Jebb used welfare discourse rather than human rights discourse, arguing in favour of protecting children's process of growing up and future wellbeing as adults. The same rhetoric would later be used in the League of Nations' Declaration that she drafted. ${ }^{54}$

Despite the differences between them, what unites Key, Korczak and Jebb is their respect for children, the recognition of their agency and the care for who they are - children. Children's prospect as adults or citizens is not the primary focus of Key, Korczak of Jebb, nor is the paternalistic approach of care for children's welfare while overlooking their wishes and feelings. One possible reason for this similarity is that all three were teachers, and as such,

\footnotetext{
${ }^{50}$ Veerman, supra n. 25, 89.

${ }^{51} \mathrm{Ibid}, 88$.

${ }^{52}$ At 1865 , more than half a century before, the organization 'The Salvation Army' was established in London.

${ }^{53}$ As quoted by Veerman, supra n. 25, 91.

${ }^{54}$ Veerman, supra n. 25, 91; Marshall, supra n. 5, 124.
} 
were in contact with children on a daily basis. Though one should wonder why all teachers do not share these views about children.

The three of them also shared the view that children should be provided with the opportunity to grow up, and to different extents, become whatever they wish to become. Korczak and Key spoke about caring for children's growth in human rights terms. The next section analyses the protection for children's development under the 1924 Declaration, showing the significance given to saving children's lives and their survival, rather than caring for their future.

\section{League of Nations Declaration on the Rights of the Child}

The League of Nations was established in 1919, after the First World War. Its primary goals were maintaining peace; ${ }^{55}$ ensuring 'fair working conditions' of men, women and children; securing 'just treatment of the native inhabitants'; preventing trafficking of women, children and narcotic drugs; supervising arms trading; maintaining freedom of communication and transit; and preventing and controlling diseases. ${ }^{56}$ In accordance with these goals, and as part of a broader project of rehabilitation of war victims, children's welfare was on the League's agenda from the beginning of its work. ${ }^{57}$

A coalition of organizations that included the International Committee of the Red Cross, the League of the Red Cross Societies, Save the Children International Union and the International Association for the Promotion of Child Welfare, together with Belgium, Switzerland, France, Greece, Italy, Portugal, Sweden, China, Morocco and Egypt, ${ }^{58}$ helped to establish the Leagues' Child Welfare Committee. One of the first items on the Committee's agenda was to adopt a children's rights charter. ${ }^{59}$ As previously mentioned, Eglantyne Jebb was the dominant figure in persuading the Committee and members of the League of Nations to adopt such a charter. ${ }^{60}$

The Declaration on the Rights of the Child, ${ }^{61}$ also known as the Geneva Declaration, was adopted on September 26, 1924. This landmark document was the first international

\footnotetext{
55 The Covenant of the League of Nations, 1924.

${ }^{56}$ Ibid, Article 23.

${ }^{57}$ Marshall, supra n. 5, 106-108.

${ }^{58}$ Ibid, 110-120.

${ }^{59}$ Ibid, 128.

${ }^{60} \mathrm{Ibid}, 128$, and Veerman, supra n. 25, 155-156.

${ }^{61}$ The Declaration on the Rights of the Child, League of Nations O.J. Spec. Supp. 21, at 43 (1924).
} 
instrument recognizing the universality of children's rights and welfare. ${ }^{62}$ But while the Declaration's title and preamble use the term 'rights', this term is not mentioned in any of the five substantive paragraphs. The substance of the Declaration uses the term 'needs', and subsequently focuses on promoting these needs, ignoring the promise to promote human rights, which the Declaration'stitle makes.

The short document mandates that certain needs of the child should be met by "men and women of all nations'. The Declaration addressed the needs of hungry children to be fed, the need of sick children to be nursed and the need to reclaim delinquent children. ${ }^{63}$ The Declaration further asserted that children should be the first to receive relief in times of distress, ${ }^{64}$ and that children need to be in a position where they can earn a livelihood, whilst being protected against every form of exploitation. ${ }^{65}$ The last paragraph of the Declaration stated that children should be brought up with the consciousness that their talents must be devoted to the service of their fellow men. ${ }^{66}$

By promoting children's needs and not children's rights, the Declaration treated the child as beneficiaries rather than as a subject of international law. ${ }^{67}$ Children are seen, according to Geraldine Van Bueren,as 'recipients of treatment' rather than right's holders. ${ }^{68}$ Nevertheless, Van Bueren claims that by linking children's needs and rights, at least at a declaratory level, the Declaration created international standards for children's rights. ${ }^{69}$ Korczak was much less satisfied with the Declaration, rightly arguing that it primarily reflects the conception of children as subjectsof care and as persons in constant need for protection, rather than respecting children's agency. In addition, since the Declaration did not assert the rightsbearing status of children themselves, Korczak claimed that it amounts to nothing more than 'an appeal to goodwill' of adults. ${ }^{70}$ Using Korczak's terminology, the Declaration asserted that adult goodwill results in protecting children from the risks that an adult-shaped world might pose to their journey toward adulthood. In similarity to the dominant perception of childhood of that time, it is the child's future development that the Geneva Declaration is

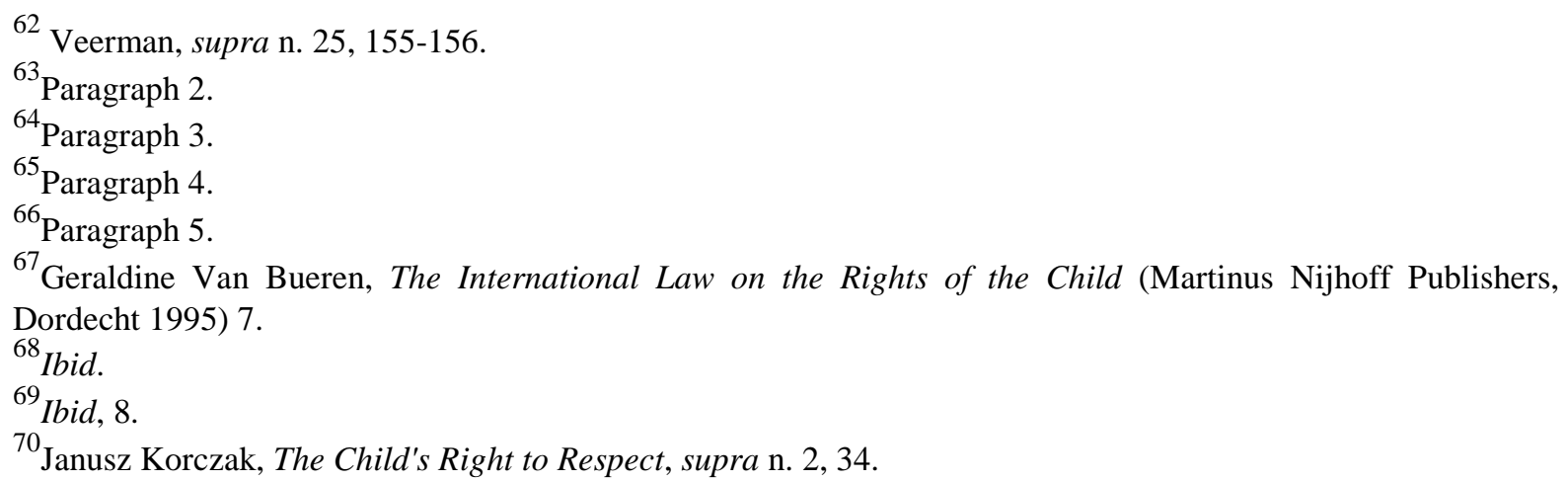


primarily concerned with. This conclusion is best demonstrated by the first Article of the Declaration, which reads:

'The child must be given the means requisite for its normal development, both materially and spiritually'

ThisArticle protects the child's 'normal development', which seems to include two elements: material and spiritual. By using the word 'must', the Article sets forth a strong obligation to ensure that the child receives the 'means' required for this 'normal development'. But theArticle is as vague as it is important. It raises the questionsof who determines what constitutes 'normality', and on what bases should this decision be drawn? It is also not clear whether this 'development' refers to a process or, rather, to the outcome of a process. The Declaration also does not elaborate on the means required to fulfil the need for this 'normal' growth, on top of referring to the two domains it covers - material and spiritual.

By protecting 'development' first, the Geneva Declaration embraced 'development' as a core principle of international children's rights law. The Geneva Declaration communicates the centrality of the role of development in the nature and aims of children's rights. It echoes developmental psychology in suggesting that there is a course of 'normal' development that ought to be protected, in contrast to an abnormal development that might jeopardize the child's future. ${ }^{71}$ The Declaration further reflects the perception that growing up is what childhood is all about and what law should enable children to do. There have been few significant changes in international children's rights law since 1924 with respect to this idea.

The next instrument in international children's rights law is the 1959 UN Declaration on the Rights of the Child. Before discussing this Declaration, I will briefly review other developments in international human rights law, namely the Universal Declaration on Human Rights and the 1966 Covenants. It would be wrong to ignore these treaties when analysing international children's rights law, as they had a significant impact on the ways in which human rights, and the identity of the rights holder, have been defined in the UN system, including by the 1959 Declaration and later on, the 1989 UN Convention on the Rights of the Child.

\footnotetext{
${ }^{71}$ See Erica Burman, Deconstructing Developmental Psychology (2 ${ }^{\text {nd }}$ edition, Routledge, London 2008) 71-73.
} 


\section{Universal Declaration on Human Rights}

The United Nations was established,like the League of Nations, following another World War. Although one of the organization's main objectives is protecting human rights, ${ }^{72}$ it took more than a decade before the UN generated any progress in international children's rights law. Progress was first made in 'general' international human rights law, with the adoption of the 1948 Universal Declaration on Human Rights (UDHR). ${ }^{73}$

The UDHR protects civil and political rights and social and economic rights alike. ${ }^{74}$ The rights holders are defined as 'all members of the human family', ${ }^{75}$ emphasising that 'all human beings are born free and equal in dignity and rights' and,therefore, 'everyone is entitled to the rights and freedoms set forth in this Declaration' ${ }^{76}$ Presumably, this definition includes children as well. ${ }^{77}$ Articles 25 (right to an adequate standard of living) and 26 (right to education) of the UDHR potentially undermine this conclusion. Reading Article 25 from a developmental perspective, the first part of it is of great importance. It reads:

'Everyone has the right to a standard of living adequate for the health and well-being of himself and of his family, including food, clothing, housing and medical care and necessary social services, and the right to security in the event of unemployment, sickness, disability, widowhood, old age or other lack of livelihood in circumstances beyond his control.'

Article 25 aims to provide all the necessary social services adequate for 'everyone(s)' 'health and well-being', but it does not stipulate what these entitlements ought to achieve or what kind of life they should facilitate. As far as children are concerned, though the term 'everyone' is in principle refers to children and adults alike, the Article nevertheless names 'himself and of his family' as the explicit right holder. Therefore it is not 'everyone' who is the right holder, but rather only those men who head a household. These men, and only these men, are entitled to the right to an adequate standard of living and social security. And it is with their courtesythat other family members, including children, benefit from this right

\footnotetext{
${ }^{72}$ Article 1(3) to the Charter of the United Nations (1945).

${ }^{73}$ UN General Assembly, Universal Declaration of Human Rights, 10 December 1948, 217 A (III).

${ }^{74}$ For some background on the document and its drafting process see Johannes Morsink, The Universal Declaration on Human Rights - Origins, Drafting and Intent (University of Pennsylvania Press, Philadelphia 1999). Chapter three of this book is dedicated to equality, women's and minorities' rights. However, the absence of children from the UDHR is not mentioned by the author. See pages 92-116.

${ }^{75}$ UDHR, Preamble.

${ }^{76}$ UDHR, Article 1.

${ }^{77}$ Hans-Joachim Heintze, 'Children's Rights within Human Rights Protection' in Michael Freeman and Philip Veerman (eds)The Ideologies of Children's Rights (Martinus Nijhoff Publishers, Dordrecht 1992) 71-78, 72.
} 
being fulfilled. Children may enjoy the fruits of having a social security net, and thus may have their development needs met. But if this happens, it is not because the children are seen as right holders.

Article 25(d) relates to children differently, and it is one of the few places in the UDHR where children are explicitly mentioned. However, Article 25(2) does not address children's right to an adequate standard of living, but rather aims to eliminate discriminatory practices that prevent children from enjoying this right. The Article echoes Key's call to disconnect children's legal status from the status of their parents,declaring that 'all children, whether born in or out of wedlock, shall enjoy the same social protection' ${ }^{78}$ Furthermore, the Article protects children from only one ground of discrimination (legal status) and in relation to only one right (adequate standard of living), while ignoring other grounds of discrimination and many other rights. Article 25 does not name children as direct rights holders, but rather asks to remove one obstacle that prevents children from enjoy the courtesy of the man who heads the household, presumably their father. Later, in the 1959 Declaration on the Rights of the Child and the UN Convention on the Rights of the Child, not only would children be acknowledged as human rights holders of both the right to an adequate standard of living and to social security, but these two rights would be connected to children's development and their right to development.

The second article to mention children is Article 26, which protects the right to education. ${ }^{79}$ Although children are obvious and immediate holders of this right, the Article refers to them only as passive actors, and as subjects of parental rights. While Article 26(1) declares that 'everyone' is entitled to the right to education, children are only mentioned in Article 26(3). Article 26(3) does not protect any issues or rights related to education of children, but rather protects the right of parents 'to choose the kind of education that shall be given to their children'. Thus, not only does the UDHR fail to address specific issues that relate to children, it also fails to recognise them as rights holders. It is against this perception of children as nonrights holder and as passive recipients of aid that the development of the protection of children's development should be realised.

The idea of 'development' is mentioned in Article 26(2), which declares: 'Education shall be directed to the full development of the human personality ...'. This is a different kind of

\footnotetext{
${ }^{78}$ For a commentary on Article 25 see Asbøjrn Eide and Wenche Barth Eide, 'Article 25' in Gudmundur Alfredsson and Asbøjrn Eide (eds) The Universal Declaration on Human Rights (Martinus Nijhoff, The Hague 1999) 523-550.

${ }^{79}$ For a commentary on Article 26 see Pentti Arajärvi, 'Article 26' in Alfredsson and Eide (eds), Ibid, 551-574.
} 
protection for development than the type ofprotection for the 'means' required for 'normal' development, which is provided under the Geneva Declaration.

Article 26(2) does not protect the 'normal' course of development, but rather refers to the outcome of the educational process. It sets a results-based test by attempting to provide for a 'full development of the human personality'. These are two different perspectives on 'human development'. One is focused on the process, while the other is keen to achieve a certain result. Though both concepts ('normal development' and 'full development') are vague and biased, they nevertheless tell us something different about the child and about childhood. Furthermore, the UDHR definition for development is broader, as it relates to the child's personality in general, rather than only to her or his maternal or spiritual development.

The UDHR was an important step in promoting human rights, and in putting human rights on the world's agenda during the Cold War. Therefore, its overall contribution to international human rights law should not be dismissed. Having said that, the general progress the UDHR has generated had a relatively lesser impact on children. Children's legal and social status under the UDHR can be described as: children are not yet adults, and the meaning of this gap is inferiority. Consequently, broad protection should be given to their development.

\section{UN Declaration on the Rights of the Child}

In 1950, soon after the UDHR was adopted, the UN Social Commission asked the UN Secretary General to draft a declaration concerning the rights of the child. ${ }^{80}$ Nine years later, in 1959, during which time other 'general' human rights conventions were drafted as well (later resulted in the 1966 Covenants), ${ }^{81}$ the General Assembly adopted the Declaration on the Rights of the Child. ${ }^{82}$

This new declaration was intended, according to the UN Social Commission, to 'emphasize the need for special care of the rights of the child because of his immaturity in respect to a name, nationality, security, health, education and protection against all forms of exploitation which might prejudice his development'. ${ }^{83}$ The Commission perceived the child as an

\footnotetext{
${ }^{80}$ Legislative History of the Convention on the Rights of the Child, supra n. 1, 4.

${ }^{81}$ Henry J. Steineret al, International Human Rights Law in Context ( $3^{\text {rd }}$ edition, Oxford University Press, Oxford 2007) 136.

${ }^{82}$ Declaration on the Rights of the Child (Adopted by UN General Assembly Resolution 1386 (XIV) of 10 December 1959). For a background on the drafting process see Veerman, supra n. 25, 161-166.

${ }^{83}$ Legislative History of the Convention on the Rights of the Child, supra n. 1, 5. Emphasis Added.
} 
'immature' person and as such, it sought to protect the child's development from six potentially threatening elements: not having a name; not having a nationality; security; health; education and exploitation. Once provided with this protection, the child could then develop and become an adult. These six components of development are different from the two developmental components of the Geneva Declaration (material and spiritual), and reflect a broader conception of development -in terms of what harms 'development' and what advances 'development'. These components can also be seen as an attempt to concretise the UDHR's 'full development' model.

The first draft of the new Declaration included ten substantial principles. The first principle followed the Commission's mandate and stated:

'the child shall be given the means necessary to enable him to develop physically, mentally, morally, spiritually and socially in a healthy and normal manner and in conditions of freedom and dignity'. ${ }^{84}$

Principles 4, 6 and 9 protected additional aspects of child's development and introduced new dimensions of the right. Principle 4 protected the child's right to social security. Unlike the UDHR, Principe 4 recognised children as right holders, and stated that the child 'shall be entitled to grow and develop in health...'. By emphasising 'grow' and linking it to 'development', Principle 4 provides protection for the process of development, not for its outcome, and identifies 'health' as the indicator for a successful process of growth.

Principle 6 declares that the child 'needs love and understanding,' as these needs are essential 'for the full and harmonious development of his personality'. This obscure statement, similar to those made by Korczak and Key, is not often found in human rights instruments. This Principle takes the human desire for love and transforms it into a need, fulfillment of which should generate the process of 'full and harmonious development' of the child. As such, Principle 6 defines a broad, but nevertheless vague, spectrum of development, as it ought to be both 'full' and 'harmonious'. Oddly, the Principle does not name 'normal' as a characteristic for this course of development.

Principle 9 is similar to the fourth Principle of the Geneva Declaration. It declares that the child shall 'in no case be caused or permitted to engage in any occupation or employment which would prejudice his health or education, or interfere with his physical, mental or moral development'. This Principlereflects a concern that child labour might not only be hazardous 
to the children's health or education, but would also jeopardise three aspects of development: physical, mental and moral. Principle 9 is important for two reasons. First, it detaches development from the right to health, social security or education and acknowledges the independent and distinct importance of development for children. Second, it expands children's development to include three explicit components (physical development, mental development and moral development) as opposed to only one or two components, and surely expands upon more ambiguous concepts such as 'full development' or 'harmonious development'. However, Principle 9 makes these distinctions only in relation to occupation or employment, excluding other activities or situations that may interfere with children's development.

In 1959, Cuevas Cancino, the Rapporteur of the Declaration's Drafting Committee, presented the final text to the UN General Assembly, which was very similar to the first draft. In his speech, Cancinodescribed the ideas that lay at the heart of the Declaration. Upholding Durkheim's principle of childhood as a time governed by the 'law of growth', ${ }^{85}$ Cancino emphasized the importance of protecting children's development by international law:

'a human being that is to say, in a state of physical and moral growth...The draft Declaration dwells upon the ultimate contribution which the child will make to the human group to which he belongs. The child is given rights so that he may become a complete and perfect human being... It is not surprising that the draft Declaration should attach such importance to the spiritual factors, which determine the development of the child... As being in a process of development, the child requires special protection in that process; his development must be neither impeded nor forced into antisocial directions'. ${ }^{86}$

Cancino continued expressing strong views concerning childhood and children's development, adding that the Declaration considers the child as an 'immature being', and therefore 'sets forth those rights which it regards as essential to the child's full development'. ${ }^{87}$ It is not only the content of the speech, but also its patronizing tone that reveals the Declaration's perception of children, childhood, children's rights and children's development. The speech portrays a clear image of the child:the child is immature, her or his course of growth should be protected, especially with regard to spiritual development, and eventually, the child should not only turn into an adult, but more specifically, should turn into a

\footnotetext{
${ }^{85}$ See the Introduction, next to footnote 42.

${ }^{86}$ Legislative History of the Convention on the Rights of the Child, supra n. 1, 21.

${ }^{87}$ Ibid, 22.
} 
'complete and perfect' one. According to Cancino, the Declaration does not acknowledge children's human rights because it respects them as human beings, but rather 'gives' children some human rights so they can become 'a complete and perfect human being'. These words sound like a contractual condition, rather than a human rights declaration. Children are obliged to grow up in a particular way, forbidding them to become an 'anti social' person, in return for receiving human rights.

Principle 2 of the final text of the Declaration perfectly demonstrates these ideas:

'The child shall enjoy special protection, and shall be given opportunities and facilities, by law and by other means, to enable him to develop physically, mentally, morally, spiritually and socially in a healthy and normal manner and in conditions of freedom and dignity. In the enactment of laws for this purpose, the best interests of the child shall be the paramount consideration'

The Principle defines a broader spectrum of development than previously defined, and declares what the goals of development are and what the development process should look like. While the first draft protected six components of development (name, nationality, security, health, education and exploitation), this Principle delineates five components of child development - physical, mental, moral, spiritual and social development, tying them all to the principle of 'best interests' of the child. This is the first time that the 'best interests principle' is mentioned in an international document, ${ }^{88}$ and one of the rare occasions where it is connected to the concept of 'development'.

Reading principles 2, 4, 6 and 9 and Cancino'sspeech demonstrate the typical perception of childhood and children as the negative others. The Declaration takes the position that since the child's purpose is to grow up, international human rights law should protect the child's physical, mental, moral, spiritual, social and full and harmonious development as a means of ensuring the outcome of this process. Underscoring the process of growing up in this way reflects a conception of childhood that emphasises the end point of the developmental process, where the child turns into a 'fully developed' adult.

The Declaration began to clarify the meaning of 'child's development', specifies its components, and attaching more aspects of the child's life to her or his course of growth. Taken together with the Geneva Declaration, the two Declarations establish the centrality of the idea of children as developing human beings in international children's rights law; the

\footnotetext{
${ }^{88}$ Michael Freeman, Article 3 - The Best Interests of the Child (Martinus Nijhoff Publishers, Leiden 2007) 15.
} 
urge to protect children's 'development'; and the hesitation to see children as human rights holders. Both Declarations, at least with respect to 'children's development', subjugate the justification for recognizing children as human rights holders to the support of children's development. Nonetheless, neither of the Declarations identifies a legal right to development.

\section{The 1960's and the Emerging Recognition of Children's Autonomy}

The 1959 UN Declaration on the Rights of the Child was adopted on the threshold of the 1960 's and the rise of the human rights movements. It was during this period that women's rights, black people's rights and anti-colonial movements gained impressive victories in promoting their agendas. ${ }^{89}$ Some calls to recognise children's rights were expressed as well, ${ }^{90}$ but it is difficult to speak of any significant 'children's rights movement' occurring during this time, at least not on the same scale as these other human rights movements. The changes in legal rhetoric and practices generated by the human rights movements led to some progress in the area of children, but the obsession with protecting their 'development' remained virtually unchanged in law and in mainstream legal theory.

In the United States, for example, children began to be seen as civil rights holders under one of the two paradigms that emerged. The first paradigm, as identified by Hillary Rodham, took the view that children should be granted equal protection for their rights in the same ways that adults have. According to Rodham, this approach mainly influenced criminal law, and the United States Supreme Court adopted it in 1967, inIn Re Gault. ${ }^{91}$ In this case, dealing with the conviction of fifteen year old Gerald Gault, the Court concluded that 'neither the Fourteenth Amendment nor the Bill of Rights is for adults alone' ${ }^{92}$ The approach that there was no reason for denying children any of the rights promised to adults prevailed in this area of law until very recently. ${ }^{93}$ This approach will be further discussed in the next section, with respect to the child liberation movement that bloomed in the USA during the 1960's and 1970's. The secondparadigm followed the traditional welfare paradigm, asking to protect

\footnotetext{
${ }^{89}$ Micheline R. Ishay, The History of Human Rights (University of California Press, Berkeley 2008) 191-205, 225-243.

${ }^{90}$ Veerman, supra n. 25, 113-124.

${ }^{91}$ In Re Gault, 387 U.S. 1 (1967).

${ }^{92}$ Ibid, 13.

93 See the latest Supreme Court judgments that bar mandatory life term for juvenile (Miller v. Alabama 567 U.S. ___(2012)), determining that juvenile offenders can not be sentenced to life imprisonment without parole for non-homicide offences (Graham v. Florida 560 U.S _ _ (2010)), and invalidating the death penalty for all juvenile offenders under the age of 18 (Roper v. Simmons $\overline{543}$ U.S. 551 (2005)).
} 
children from abuse and neglect and to promote their well-being. Its influence expanded the juvenile justice system, and it changed family law and education law. According to Rodham, legislation allied with this welfare tended to unveil 'a blueprint for the child's fullest development' ${ }^{94}$ Nonetheless, Rodham argued that new legislation and case law that were based on this perspective reflected a conceptual stagnation of childhood, rather than progress towards recognition of children as rights holders. Children's status as civil rights holderswas not recognized because:

"these "needs manifestos" proclaim the rights of children to adequate nutrition, a healthy environment, continues loving care, a sympathetic community, intellectual and emotional stimulation, and other prerequisites for healthy adulthood. Although a child may be entitled to such rights under theories of natural law or moral philosophy, most claims based on psychological and even physical needs are not yet considered legal rights by our system. ${ }^{95}$

Rodham draws an important distinction between what adults see as psychological and physical needs of the child and what the law does. She highlights the role that psychology plays in the legal field and the impact it has on the formulation and interpretation of children's human rights. Rodham does not argue against utilizing psychology in law, but suggests that children's needs as identified by other disciplines are not necessarily recognised as human rights. Robert Geiser shares Rodham's analysis concerning the importance given to child's development in United States law. Focusing on mental health law, Geiser argued that

'children's rights are often given a developmental justification - that is, children need these rights satisfied in order to develop into physically and mentally healthy adults and to realise their full potential as human beings'. 96

These exponents of children's rights', he continues, 'prescribe a catalogue of the needs of children which must be met to ensure the development of children into productive citizens' ${ }^{97}$

\footnotetext{
${ }^{94}$ Hillary Rodham, 'Children Under the Law' (1973) 43 Harvard Educational Review 487, 494. For a review of the changing attitude toward children in US laws during this time see also Bruce C. Hafen, 'Children's Liberation and the New Egalitarianism: Some Reservations About Abandoning Youth to Their "Rights"” [1976] BYU Law Review 605.

${ }^{95}$ Rodham, Ibid.

${ }^{96}$ Geiser, supra n. 10, 1040.

${ }^{97}$ Ibid, 1044. For a review on the rise of children's rights in the UK during this time see Bob Franklin (ed) The Rights of Children (Basil Blackwell, Oxford 1986).
} 
The influence of developmental psychology on legal theoryand positive law, as well as on the way in which law imagines 'the child,' is clear. Geiser argues that protecting children's rights is understood as a means to an end, and that children's rights are not respected due to acknowledgement of children's humanity. According to this approach, children's rights are the legal modification of children's welfare needs and of developmental psychology, and are designed to facilitate children's development. Law does not define what these needs are or what 'children's development' means, but rather serves as a tool to promote those needs.

On the international level, the rise of the human rights movement resulted in the adoption of two human rights treaties in 1966: The International Covenant on Civil and Political Rights $(\mathrm{ICCPR})^{98}$ and the International Covenant on Economic, Social and Cultural Rights (ICESCR). ${ }^{99}$ Although these Covenants signified major progress for the protection of the human rights of 'all' human beings, as both Covenants state, the term 'all' does not always include all part of society, and too often, certain social groups and individuals, including children, found themselves being left at the margins in practice. Nevertheless, and despite strong opposition during the drafting process, ${ }^{100}$ bothinclude specific clauses dedicated to children and some of their rights, excluding the right to development.

Common Article 3 of the ICCPR and ICESCR aims to protect the 'equal rights of men and women'. In addition, the ICCPR refers to 'all individuals' (Article 2) and to 'every human being' (Article 6) as rights holders. The ICCPR declares that 'everyone shall have the right to recognition everywhere as a person before the law' (article 16). In similarity to the UDHR, these definitions seem to include children, but in practice, children, like other discriminated groups, were marginalised from these seemingly inclusive definitions. For this reason, and in order to stress the need to protect the rights of members of some of these groups, the Covenants dedicate specific provisions for the rights of women and children. Later, both groups will be the subjects of specific human rights conventions: The Convention on the Elimination of all Forms of Discrimination against Women and the Convention on the Rights of the Child.

\footnotetext{
${ }^{98}$ The International Covenant on Civil and Political Rights, Adopted and opened to signature, ratification and accession by General Assembly Resolution 2200A (XXI) of 16 December 1996. Entered into force on 23 March 1976.

99 The International Covenant on Economic, Social and Cultural Rights, Adopted and opened to signature, ratification and accession by General Assembly Resolution 2200A (XXI) of 16 December 1966. Enter into force on 3 January 1976.

${ }^{100}$ Manfred Nowak, U.N. Covenant on Civil and Political Rights - CCPR Commentary (N.P. Engel, Kehl 1993) 422-434, 423.
} 
Article 24 of the ICCPR recognises children's right to non-discrimination, the right to 'measures of protection as are required by his status as a minor, on the part of his family, society and the State', the right to be registered after birth, the right for a name and the right to acquire a nationality. ${ }^{101}$ In addition, four other articles mention children's rights. Article $6(5)$ protects the right to life and establishes that 'persons' below the age of 18 should not be sentenced to death. Articles 10(2)(b) and 14(4) address the rights of children in criminal procedure. Article 23 protects the right of 'men and women' to marry and protects children when marriage ends.

These articles reflect a liberal interpretation of equality and take a minimalistic approach towards children and their rights. The articles further express concern with preventing harm, but none of them(or any of the other articles in the Covenant), refer explicitly or implicitly to children, their needs, including their developmental needs, or their future.

The ICESCR addresses even fewer rights of the child than the ICCPR. Article 10(3) deals with families, and requires States Parties to take 'special measures of protection and assistance' on behalf of:

'all children and young persons without any discrimination for reasons of parentage or other conditions. Children and young persons should be protected from economic and social exploitation. Their employment in work harmful to their morals or health or dangerous to life or likely to hamper their normal development should be punishable by law...'

Children's right to non-discrimination is protected, and the ground of parental status is explicitly mentioned (inline with Key's suggestion). To a limited extent, the Article also protects children's development. Using the same term as the Geneva Declaration, children's 'normal development' should not be obstructed (in addition to being actively promoted), but only in relation to the labour market. It is not clear from the text whether the child's 'normal development' refers to the process or the outcome of it. Article 13 refers to the right to education, ${ }^{102}$ and 'recognise[s] the right of everyone to education'. In similarity to Article 26 of the UDHR, Article 13 does not name children as rights holders and again, like Article 26, children are mentioned only in reference to the parental right to choose a child's education (Article 13(3)).

\footnotetext{
${ }^{101}$ Ibid.

${ }^{102}$ For a comprehensive analysis of Article 13 see Klaus Dieter Beiter, The Protection of the Right to Education by International Law (Martinus Nijhoff Publishes, Leiden 2006) 459-569.
} 
As neither children nor their rights receive significant attention in these two important Covenants, it is difficult to draw definite conclusions concerning the image of the child or the care for their development they reflect or ask to promote. Nevertheless, mentioning children as rights holders in a binding convention is not without significance. Children are seen as a distinct and defined social group, and to some extent, this recognition further respect their agency.

\section{The Child Liberation Movement}

The children liberation movement emerged in the United Kingdom and the United States in the late 1960's and 1970's. After a decade of activity, it gradually faded away until it virtually vanished. Today, it is hard to find any reference to its ideas, as they were dismissed for being too simplistic. I nevertheless argue that despite its simplicity, insofar the jurisprudence about the child's right to development, there is much to learn from this movement.

The child liberationists called for the end of paternalistic approaches towards children, for the elimination of the discrimination between children and adults, to grant children the same constitutional rights as adults, and ultimately to make children free beings. ${ }^{103}$ According to Martha Minow, the usage of equality discourse and the language of rights, 'offered a way to argue for both more protection and more independence for different children, or for the same children in different circumstances. ${ }^{104}$ However, Nan Berger argues that dissolving discriminatory legislation is not enough, because in order to promote children's rights, there is also a need to recognise children's agency and give them a voice. ${ }^{105}$

'While much could be done through alternation and modification of the law to bring freedom to children, children could not, like Negroes and women, be liberated entirely by the actions of others. Freedom, if it is gained at all meaningfully, is self-gained and the most helpful thing which could be done toward this end would be to make children involved in the decisions in their own life from a very early age.'106

\footnotetext{
${ }^{103}$ For a general background see Veerman, supra n. 25, 133-152; Michael S. Wald, 'Children's Rights: A Framework for Analysis' (1979) 12 University California Davis Law Review 255; In the UK, liberationists came forward a decade later. See Bob Franklin, supran. 97.

${ }^{104}$ Martha Minow, 'What Ever Happened to Children's Rights' (1995-1996) 80 Minnesota Law Review 267, 273.

${ }^{105}$ Nan Berger, 'The Child, the Law and the State' in Paul Adams et al (eds) Children's Rights(Elek Books, London 1971) 153-179; See also Ann Palmeri, 'Childhood's End: Toward the Liberation of Children' in William Aiken and Hugh LaFollette (eds) Whose Child? (Rowman and Littlefield, Totowa, New Jersey 1980) 105-124.

${ }^{106}$ Berger, Ibid.
} 
The liberationists' approach marks a significant change in the field of children's rights. To a large extent, this movement shifted attention away from the welfare paradigm and the general developmental perception of childhood in law, by offering new ways to conceptualise childhood and a new understanding of children's human rights. Since most of the liberationists worked and wrote in the United States, much of their focus was on the protection of children's constitutional rights. ${ }^{107}$

Before addressing the contribution of the children's liberationists to the debate concerning 'development' and law, and at the risk of generalizing and over-simplifying, I will first summarise their theories. The children's liberationists rejected the welfare paradigm and the perception that 'rationality' is a necessary component in executing human rights. Instead, they demanded respect for the equal rights of children. Moreover, some liberationists, like Ann Palmeri, claimed that the argument that requires mental and cognitive capabilities as a prerequisite for either having or exhausting rights is not valid for two reasons. The first is that children have the sufficient and necessary capacities to make an autonomous choice, and the second is that children have at least as much capacity as adults. ${ }^{108}$ The liberationists also rejected the usage of developmental psychology in conceptualising childhood. They considered children as 'persons', claiming that 'childhood is a stage in life with internal significance in and of itself, and not just an apprenticeship. Society should acknowledge that and until it does and expresses this understanding in action, children will remain appendages of others and will be unable to develop in their own image' ${ }^{109}$ The liberationists were keen on reforming social and parental attitudes toward children. John Holt, one of the prominent advocates of this idea, claimed that a child should have the right to do what any adult may legally do. ${ }^{110}$ Richard Farson used different words to describe the same idea, suggesting that society should have a 'single standard of morality and behavior for children and adult. ${ }^{11}$

Theseideas reflect a liberal model of equality and reject the social structure that oppresses children. This perception challenged the welfare paradigm and the conception of children as 'adults in making' and accordingly, parental domination over children.As A.S Neill claimed:

\footnotetext{
${ }^{107}$ See Annie Franklin and Bob Franklin, 'Growing Pains: The developing Children's Rights Movement in the UK' in Jane Pilcher and Stephen Wagg (eds) Thatcher's Children? (Falmer Press, London 1996) 94-113. 108 Palmeri, supran.106, 110; Katherine Hunt Federle, 'Looking Ahead: An Empowerment Perspective on the Rights of the Child' (1995) 689 Temple Law Review 1585, 1593.

${ }^{109}$ Berger, supra n. 106, 153 - 179.

${ }^{110}$ John Holt, Escape From Childhood (Penguin Books, Middlesex 1974) 19.

${ }^{111}$ Richard E. Farson, Birthrights (Macmillan, University of Michigan Press, Michigan 1974) 27.
} 
'the two enemies of children are ignorance of parents and unhappiness of marriages.... The problem is parents, always parental. Children are ruined by the complexes of their parents'. ${ }^{12}$

As part of rejecting what they saw as an oppressive social order, the liberationists also challenged one of the welfare paradigm' crown jewels: compulsory school attendance. According to Berger, and in similarity to Key's approach in Century of the Child, schools are used by society to oppress children's minds, to programme children's future and to make children dependent on their parents for a longer time. ${ }^{113}$

The liberationists generated a huge amount of controversy and gained considerable criticism. They were accused of promoting an irresponsible approach that leads to abandoning children to their rights. ${ }^{114}$ In 1979 , Michael Freeman claimed that 'the liberationists' case is politically naïve, philosophically faulty and psychologically wrong'. ${ }^{115}$ With respect to the right to development, the argument about what is psychologically right or wrong is at the heart of the debate. Rejecting developmental psychology as the basic for understanding children's rights might indeed undermine their entire theory, but it can also open the door for new and different interpretations of children's rights in general, and of their right to development in particular. Throughout the Thesis, especially in the last two chapters, I make the claim that mainstream developmental psychology limited the interpretation of the right to development, and precluded from understanding this right in any way other than as a right that protects the child's transformation into an adult.

Now I would like to focus on the liberationists' critique of the developmental model of childhood, their alternative views concerning childhood and the similarities and differences between their approaches to the right to self-determination and protection of children's development.

The liberationists argued against using developmental psychology as a criterion to dictate law and policy toward children. Palmeri made the point that because there is no serious way to determine or define what 'developed enough' means, there is no justification for using capabilities in order to determine one's entitlements to have rights.

\footnotetext{
${ }^{112}$ A. S. Neill, 'Freedom Works' in Adams et al (eds), supra n.105, 127-152, 131-132.

${ }^{113}$ Berger, supra n. 106, 158-159.

${ }^{114}$ Hafen, supra n. 94, 644-650.

${ }^{115}$ Michael Freeman, 'Children's Rights and Some Unanswered Questions and Some Unquestioned Answers' (1979-1980) 5 Poly Law Review 9, 15.
} 
'We lack an adequate psychological account of the process of development and, therefore, we also lack satisfactory criteria for recognizing the "end product" of this development. How we are to determine when children possess such a capacity is very unclear. Accordingly, we have only the vaguest idea of what counts as a "moral being"'. 116

This view challenges the certainty that developmental psychology pretends to provide. If taken seriously, this view has the potential to undermine the coreprinciples of international children's rights law, as reflected in both the 1924 and 1959 Declarations. However, one can ask what Palmeri would have argued if a more 'scientific' or 'satisfactory' criteria for determining what 'sufficient capabilities' is had become available, for example in the form of empirical tests and neurology. Alternatively, she argued that if the notion of 'development' is considered important, then it should be expanded to all ages, ${ }^{117}$ so that all people, including adults, will be subject to the same regime. In this way, then, there is a chance to create 'a world where people have the best characteristic[s] of both adults and children'. ${ }^{118}$ One way or the other, if 'development' is the wrong image of the child, then according to this understanding of 'development', there is no justified need to protect the child's right to development.

Robert Ollendorfstands on the other side of the equation concerning the use of developmental psychology. ${ }^{119}$ For Ollendorf, developmental psychology signifies the right way to understand childhood, defining the discipline as a necessary model to analyse both childhood and adolescence alike.His main project is to distinguish between childhood and adolescence, claiming that adolescence is the most important phase of human life. In embracing the welfare paradigm, he defines adolescence against the image of the child (which was created as a mirror image of adults), conceptualises adolescence as a time when the child is no longer dependent, immature, non-productive and a non-responsible sexual actor, but rather almost an adult. $^{120}$

Somewhat confusingly, and although Ollendorf embraced developmental psychology as the right approach to childhood, he nevertheless rejected the capacities approach as a benchmark

\footnotetext{
${ }^{116}$ Palmeri, supra n. 106, 110.

${ }^{117}$ Ibid, 119 .

${ }^{118}$ Ibid, 121. For more on the limitation of the developmental paradigm see Arlene Skolnick, 'The Limits of Childhood: Conceptions of Child Development and Social Context' (1975) 39 Law \& Contemporary Problems $38,52-59$.

${ }^{119}$ Robert Ollendorf, 'The Rights of Adolescents' in Adams et al (eds), supra n. 105, 91-126.

${ }^{120}$ Ibid 99.
} 
for acknowledging the human rights of children. Ollendorf claims that the child should be able to determine 'on his own how he is going to learn, what he wants, what he rejects, what kind of art he likes, what kind of art he dislikes, what books he wants to read, in which way, if any, he wants to worship'. ${ }^{121}$ However, and in spite of the importance he gives to the development process, development is not named as part of this list of rights. Instead, Ollendorf names four other rights that the adolescent childshould be entitled to in order to ensure their adequate development: the right to self-determination; the right to sexual freedom; the right to education and the right to work. ${ }^{122}$ Implementing these rights should 'ultimately' lead, according to Ollendorf, to the 'promise of a happier future'. ${ }^{123}$

This approach praises the child's future and the child's current life. It takes the end point of 'development' as an important goal, but the means of achieving it are different from those presented by the welfare paradigm. Instead of emphasizing needs, Ollendorf emphasises autonomous rights as the means to achieve a very similar aim. A competent adult will be 'created' only by respecting the adolescent's liberal freedoms.

Paul Adams stands in between Palmeri and Ollendorf. Adams adopted the general Freudian's developmental model, and perceives childhood to be a time of change and growth. ${ }^{124}$ However, he disagrees with Palmeri, arguing that psychiatry and psychology can measure 'true competence'. Adams does not use the developmental approach as a reason to deny children their rights, but rather argues that children should have a 'right to a healthy childhood'. ${ }^{125}$ This right includes three dimensions: A. objective dimensions(competence and custodial stability) B. neither entirely objective, nor entirely subjective dimensions (entitlement to grow and learn, to live in a meaningful world and the opportunity for 'unfolding of loving relations with other people'); and C. subjective dimensions (a 'favorable picture of self' and a 'sense of some unsocialised uniqueness'). ${ }^{126}$ It is evident that this approach is entrenched within development psychology. Even the 'objective' aspects are biased and subjective. Such an attempt to formulate emotional needs of the child as bases for human rights, and as valid as these needs may be according to any psychological theory, fails.

\footnotetext{
${ }^{121}$ Ibid, 120.

${ }^{122}$ Ibid, 119-120.

${ }^{123}$ Ibid, 126.

${ }^{124}$ Paul Adams, 'The Infant, the Family and Society' in Adams et al (eds), supra n. 105, 51-90, 82-86.

${ }^{125}$ Ibid, 89.

${ }^{126}$ Ibid, 89-90.
} 
A more comprehensive approach to children's development can be found in John Holt's seminal book Escape from Childhood. ${ }^{127}$ Holt rejects the division between childhood and adulthood, ${ }^{128}$ and challenges the common paradigm of childhood as a time of happiness and of gradual development into a mature adult.

'Childhood, as in happy, safe, protected, innocent Childhood, does not exist for many children. For many other children, however good it may be, childhood goes on far too long, and there is no gradual, sensible, and painless way to grow out of it or leave it'. ${ }^{129}$

It is not only the being happy nature of childhood that Holt dismisses, but also the perception that a child will gradually 'grow out' towards a desirable end.In principle, he rejects the basis of the developmental model. Based on the position that there is no difference between childhood and adulthood, it follows that there should be no difference in the legal rights children hold. Consequently, children's human rights should be acknowledged and protected in the same way that adults' rights are acknowledged and protected. Holt names what he believes to be the most important eleven human rights of children. The first right on his list is the right to vote. It is followed by the right to work, the right to own property, the right to a guaranteed income, the right to choose one's guardian, the right to travel, the right to drive, the right to control one's sex life, the right to use drugs, the right to total legal and financial responsibility and the right to control one's learning.

This list is in some ways similar to Key's list and perfectly symbolises the liberationists' approach. This list not only makes the case for granting children the same rights as adults, but primarily seeks to liberate children from many of the restraints they face in their daily lives in the USA. The rights to travel, drive, have sex and use drugs are dissimilar from any other list of human rights, reflecting the spirit of the 1960's.

Nonetheless, the list challenges those who argue that lack of capabilities requires denying some of the rights of children, in favour of satisfying their needs. For this reason, the first right on Holt's list is the right to vote, perhaps the most important political right, which has always been denied to children in both the United States and the United Kingdom. Among other things, the right to vote is the right that enables a person to participate in determining how her future will look and how life will be regulated. Granting children the right to vote

\footnotetext{
${ }^{127}$ Holt, supra n. 110.

${ }^{128}$ Ibid.

${ }^{129}$ Ibid, 23
} 
contradicts T.H Marshall's claim that children cannot be citizens because they are 'citizens in making'. ${ }^{130}$ Without the right to vote, children will always remain subject to policies determined by others. ${ }^{131}$

Following his rejectionof the distinction between childhood and adulthood, Holt claims that phrases such as 'a child needs to be allowed to be a child' are meaningless, since there is no such thing as a 'child'. ${ }^{132} \mathrm{He}$ also rejects the 'development' model as part of rejecting all alleged unique characteristics of childhood. ${ }^{133}$ As a result, a right 'to development' is not part of his list of rights that children should have.

Joel Feinberg expresses a position similar to Holt's in his essay The Child's Right to an Open-Future. ${ }^{134}$ While Feinberg asserts that children should have the same human rights as adults have, unlike Holt he does not think that children can execute all of their human rights, since they are 'quite different animals'. ${ }^{135}$ Feinberg tries to eradicate what he believes to be a misunderstanding of children's rights, and to offer a conceptual solution of his own. Feinberg suggests dividing human rights into three categories. The first category includes rights that adults and children share, such as the right to body integrity (Feinberg name this category 'AC rights'). The second category includes rights that belong only to adults, such as the right to vote ('A rights'). The third and final category includes rights that are not particular to children but characteristic of them ('C- rights', or 'rights in trust'). ${ }^{136} \mathrm{He}$ defines rights in trust as those rights that children cannot execute during the time of childhood, but will be available to children as 'future options [and will be] kept open until he [the child] is a fully formed self-determining adult capable of deciding among them'. ${ }^{137}$ As such, a 'right in trust' fulfils the child's right to an open future. ${ }^{138}$ According to Feinberg, understanding some rights of children as 'rights in trust' solves the tension between capacities, rights and

\footnotetext{
130 T.H. Marshall, 'Citizenship and Social Class' in T.H Marshall, Citizenship and Social Class and Other Essays (Cambridge University Press, Cambridge 1951) 1-86, 84.

${ }^{131}$ See Aoife Nolan, 'The Child as 'Democratic Citizen': Challenging the 'Participation Gap' (2010) 4 Public Law 767.

${ }^{132}$ Holt, supra n. 110, 110-112.

${ }^{133} \mathrm{Ibid}, 77$.

${ }^{134}$ Joel Feinberg, 'The Child's Right to an Open Future' In Aiken and LaFollette (eds), supra n. 105, 124-153.

${ }^{135} \mathrm{Ibid}, 126$.

${ }^{136} \mathrm{Ibid}, 125$.

${ }^{137}$ Ibid.

${ }^{138}$ Ibid, 126.
} 
autonomy. ${ }^{139}$ Despite promising children the right to an open future, Feinberg does not think that they have a right to pursue their future.

In order to explain and simplify his approach, Feinberg takes the right of a two-month-old baby to walk freely down the street as an example. According to Feinberg, despite the obvious lack of physical capabilities of this child to walk down the street, this child nevertheless has the right to walk freely, and this right should not be forbidden or dismissed. However, if we fail to acknowledge the future usage of this right, we might end up cutting this child's legs and argue that it did not prevent the child from exhausting her right to walk freely in present time. If we do so, and this is the key to Feinberg's theory, we undermine the child's right to walk freely in the future. ${ }^{140}$

'right-in-trust cannot always be established by checking the child's present interests, a fortiori it cannot be established by determining the child's present desires of preferences. It is the adult he is to become who must exercise the choice, more exactly, the adult she will become if his basic options are kept open and his growth kept "natural" or unforced". In any case, that adult does not exist yet, and perhaps he never will. But the child is potentially that adult, and it is that adult who is the person whose autonomy must be protected now' ${ }^{141}$

Feinberg's theory requires evaluating the child's development, and hence takes children as not-sufficiently developed human beings. Feinberg seeks to enable the future adult that hides within every child the opportunity to come into life and enjoy the entire spectrum of human rights. 'It is that adult who is the person whose autonomy must be protected now' ${ }^{142}$ he claims. Feinberg is therefore willing to compromise some of the child's fundamental autonomy rights, since a 'child's future autonomy, as an adult, often requires preventing his free choice now'. ${ }^{143}$ This proposition has an inherent theoretical difficulty, as Feinberg compromises the right to free choice, which is fundamental to the liberal theory, in favour of the ability to execute that right in the future.

Feinberg does not justify his argument by using developmental arguments, nor does he describe any developmental stages. But he does see an end point where the process of changing terminates and the child reaches sufficient autonomy. Feinberg sees the end point of

\footnotetext{
${ }^{139}$ Ibid, 126-127.

${ }^{140}$ Ibid, 127.

${ }^{141}$ Ibid.

${ }^{142}$ Ibid.

${ }^{143}$ Ibid.
} 
childhood as a goal that requires protection throughout childhood. Moreover, for Feinberg, this end point is not only an interest of the child, but also a right 'because to some extent, the child's own good (self-fulfilment) depends on which interests the parents decide to create'. ${ }^{144}$ This point draws a clear divide between him and the rest of the liberationists, who seek to disengage children rights from parental rights. Though he is not using this term, he would probably understand a right to development as the right to become a free adult.

The finalliberationist addressed here is Richard Farson. Farson presented probably the most extreme liberal point of view in his book Birthrights, published in $1974 .{ }^{145}$ In Birthrights, Farson claims that despite the sense of achievement with respect to children's rights that some, like Rodham, had described, the children's rights movement did not achieve much. Moreover, it certainly did not liberate children or lead to social or legal recognition of their humanity. In fact, he claims that the increasing attention to children only led to a situation where 'children's rights have actually diminished, for we have simply replaced ignorant domination of children with sophisticated domination'. ${ }^{146}$ According to Farson, the current social structure should be revoked not only because it 'is not a good place for children', but primarily because society 'refuses their right to full humanity' ${ }^{147}$ For Farson, then, children are already 'full' human beings and, as such, do not need protection in order to develop and become ones.

Farson believed that children have the capabilities and the rights not only to determine their own future, but of their present as well. 'Children like adults', he writes, 'should have the right to decide the matters which affect them most directly' ${ }^{148}$ Like the other liberationists, Farson claimed that children should enjoy the same human rights that adults enjoy, but his reasoning was different. He did not focus on formal equality and he dismissed claims about differences between adults and children. Rather, he claimed that 'liberation will help give children back their childhood..., ${ }^{149}$ thus rejecting characterizations of childhood as either a time of joy and innocence or as a time of violence and cruelty. ${ }^{150}$ In light of this perception, Farson offered a comprehensive list of human rights that children should have, including the

\footnotetext{
${ }^{144}$ Ibid, 148.

${ }^{145}$ Farson, supra n. 111.

${ }^{146}$ Ibid, 3 .

${ }^{147}$ Ibid, 2 .

${ }^{148}$ Ibid, 27.

${ }^{149}$ Ibid, 4 .

${ }^{150}$ Ibid, 6.
} 
right to self determination, ${ }^{151}$ the right to alternative home environment, ${ }^{152}$ the right to responsive design, ${ }^{153}$ the right to receive information, ${ }^{154}$ the right to educate oneself, ${ }^{155}$ the right to freedom from physical punishment, ${ }^{156}$ the right to sexual freedom, ${ }^{157}$ the right to economic power, ${ }^{158}$ the right to political power, ${ }^{159}$ and the right to justice. ${ }^{160}$

These rights, like those on Holt's list, aim to free children from social constraints, and grant them citizenship rights. Because Farson does not perceive children only as future adults, he does not argue for the protection of their rights to grow up. The process of growing up is not without importance for him, but it is not considered the only merit of children.

A final point that needed to be addressedis the liberationists' approach towards the right to self-determination. For the individual person, the right to self-determination means the right to make autonomous decisions, and to dictate one's own future. Most of the liberationists rejected the idea that a person's rights are subject to her or his capacities, and some also rejectedthe underlying narrative dictated by developmental psychology, which hints that children do not have the necessary capacities to make decisionsand,therefore, to be human rights holders. ${ }^{161}$ Sharon Bishop, for example, argued that 'the point of the right to self determination is to enable people to work out their own way of life in response to their own assessments of current conditions and their own interests, capacities and needs'. ${ }^{162}$ In relation to children, Bishop took anapproach similar to Feinberg's concept of rights-in-trust, arguing that:

'Young persons should be treated in whatever ways give them the strength and imagination to make use of their right to self determination autonomously when they reach maturity. Treating them in ways which are

\footnotetext{
${ }^{151}$ Ibid,26-41.

${ }^{152}$ Ibid,42-62.

${ }^{153}$ Ibid,82.

${ }^{154}$ Ibid,83-96.

${ }^{155}$ Ibid,97-112.

${ }^{156}$ Ibid,113-128.

${ }^{157}$ Ibid, 129-153.

${ }^{158}$ Ibid,154-174.

${ }^{159}$ Ibid, 175-190.

${ }^{160}$ Ibid,191-212.

${ }^{161}$ Federle makes an interesting differentiation between autonomy, capacity and power. She argues that capacity, rather than autonomy, should be the foci of conceptualising children's rights Katherine Hunt Federle, 'Rights Flow Downhill' (1994) 2 International Journal of Children's Rights 343. See also Federle, supra n. 108.

${ }^{162}$ Sharon Bishop, 'Children, Autonomy, and the Right to Self-determination' in Aiken and LaFollette (eds), supra $\mathrm{n} .105,154-177,163-164$.
} 
believed to do this is a way of respecting the right they will have when they reach maturity'. 163

These words complete the circle that starts with denying children's rights all together and ends with full liberation. The idea of 'maturity' prevails, triumphing over other dimensions of the child's life. It emphasises the result of the developmental process as the main justification for acknowledging children's right to self-determination, overlooking the importance of recognizing the rights of children during the time of childhood.

Other international human rights instruments of the time did not address the individual right to self-determination, not least because according to the liberal idea of human rights, personal autonomy and self-realisation are the underlying assumptions. The right to self-determination was discussed in relation to a broader national / collective emancipatory discourses. In chapter five I discuss the relationship between self-determination, collective rights, and personal development. Here, I focus on the claim that the right to self-determination shares some core justifications with the argument that children's human rights should be recognised in order to ensure the child's future. Both views take the child's future to be important and both take the position that it needs to be addressed by law. However, it is not sufficiently clear from the liberations writing on this subject whether it was the process of creating this future (i.e, the process of development) that matters, or whether the result of this process is important in and of itself. One way or the other, it seems that those who refer to this right, like Farson, saw significance in enabling the child to enjoy some degree of self-determination and autonomy as a child, regardless of the contribution it may or may not have to the child in the future.

\section{Conclusion}

The end of the 1970's found children and the children's rights movement in an odd situation. On the one hand, it was a fairly grounded legal presumption that children are human beings and as such, cannot be treated as anyone's property or only as subjects of welfare policies. On the other hand, paternalism remained the dominant attitude towards children in law. While they were seen as human rights holders, children were predominantly conceptualised under the Durkheim's paradigm of 'law of growth'.

${ }^{163}$ Bishop, Ibid, 175. 
Many of the changes in international human rights law during the $20^{\text {th }}$ century did not change the image of children. To a large extent, children did not enjoy the liberation process that other oppressed groups enjoyed. International law continued to perceive 'the child' as vulnerable, weak and lacking the capacities' of a persons, focusing on ensuring children's process of growth and protecting them from threatening elements that might jeopardise their transformation into independent adults. The child's traditional 'development' was a source for concern and, therefore, a source for legal protection. The approaches of the liberationists, as well as of Key or Korczak, were either actively rejected by the mainstream establishment or forgotten. International law's approach adopted 'development' as its underlying narrative, focusing on the mission of 'saving the children'.

However, while 'development' came to be a key concept, it gained no thorough analysis. Law presumably protected many components of 'development', but it was difficult to sketch a coherent picture of what it really meant. For example, what does 'normal development,' to use the words of the Geneva Declaration, mean? Who defines what 'normal' is? How does it differ, if at all, from the different terms used by the 1959 Declaration? Even if accepting the presumption that developmental psychology prevails and law ought to adopt this perspective on human life, we should ask which stream of psychology has international law adopted, or which ought it adopt, and why? Needless to say, asmany other disciplines, developmental psychology is neither homogeneous nor neutral and unbiased. ${ }^{164}$ These questions have significance only if one doubts the premise that children's main remedy is to grow up.

In 1976, the UN General Assembly celebrated the $20^{\text {th }}$ anniversary of the UN Declaration of the Rights of the Child by declaring 1979 to be the 'International Year of the Child'. ${ }^{165}$ A 'deep concern' that 'in spite all efforts, far too many children, especially in developing countries, are undernourished, are without access to adequate health services, are missing the basic educational preparation for their future and are deprived of the elementary amenities of life ${ }^{166}$ was one of the reasons for this decision. The government of Poland introduced a draft for a binding convention concerning children's rights, based on the 1959 Declaration. ${ }^{167}$ In 1989, ten years after the 'Year of the Child' and after countless debates, this draft became the

\footnotetext{
${ }^{164}$ For example, see Carol Gilligan's most influential critique of the gender biased of developmental psychology. Carol Gilligan, In a Different Voice (Harvard University Press, Cambridge 1982). See also Sara Karkness, 'The Cultural Context of Child Development' (1980) 8 New Directions of Child Development 7.

${ }^{165}$ General Assembly Resolution 31/169, adopted on 21 December 1976.

${ }^{166}$ Ibid.

${ }^{167}$ Letter from the Permanent representative of Poland to the United Nations Office at Geneva E/CN.4/1284 (18 January 1978).
} 
UN Convention on the Rights of the Child. The Polish draft for a Convention on the Rights of the Child continued this narrative. This draft was no different in its intentions and held the same vague conceptions of children and development. In the next chapter I review the draft and the entire drafting process of the UN Convention on the Rights of the Child. I focus on the drafters' perception of children's development and the course of actions that led to inclusion of a right to development in the Convention. 


\section{Chapter Two: Creating the Right To Development Of Children}

'The protection of the child should be one of the prime objectives of a social and economical development strategy. The creation of a social climate favourable to the child would perhaps eliminate some of the problems, which were obstacles to the right to development... The privileged children had a right to leisure and to the full development of their personality, and to be protected against violence, cruelty, exploitation, drugs and the slave trade, while the underprivileged children of developing societies had the right to life, to their daily bread, to shelter and to protection against underdevelopment. Only through international solidarity could children be properly protected.' (Sheikh Fadli, commenting on the first draft of the UN Convention on the Rights of the Child, 1978) ${ }^{1}$

'[T]he physical and mental nature of the child is identical everywhere... the process of growth and adolescence takes a similar course in all children. Their physical and mental needs are also similar.' (Adam Lopatka, Chairperson of the Working Group on a Draft Convention on the Rights of the Child, 1992) ${ }^{2}$

\section{Introduction}

This chapter studiesthe process of creating the child's right to development under the UN Convention on the Rights of the Child ('UNCRC' or 'The Convention'), ${ }^{3}$ and the broad protection for children's development that the Convention provides. The chapter aims to explore the potential meanings of the child's right to development, which can be concluded from the Convention's drafting process.

The UNCRC is the first, and currently the only, binding international law instrument that protects the right to development. Article 6(2) of the Convention reads:

'States Parties shall ensure to the maximum extent possible the survival and development of the child'

\footnotetext{
${ }^{1}$ UNHCR, 'Summary Record of the $1471^{\text {st }}$ Meeting' (13 March 1978) UN Doc E/CN.4/SR.1471, 11.

2 Adam Lopatka, 'The Rights of the Child are Universal: The Perspective of the UN Convention on the Rights of the Child' in Michael Freeman and Phillip Veerman (eds) The Ideologies of Children's Rights (Martinus Nijhoff Publishers, Dordrecht 1992) 47-52, 49.

3 UN Convention on the Rights of the Child 1989 (Adopted by General Assembly Resolution 44/25 of 20 November 1989, entered into force on 2 September 1990).
} 
Five additional articles - Article 18(1), Article 23(3), Article 27(1), Article 29(1)(a) and Article 32(1) - protect eight differentcomponents of 'development', namely physical, mental, moral, social, cultural, spiritual, personality and talent.

This chapter studies the process of incorporating this extensive protection of children's development into the Convention and asks when, why and how the concept of 'development' became an issue of concern for human rights law and a fundamental principle of the Convention. Taking the assumptions that different conceptions of childhoods lead to different interpretations of children's rights, the chapter analyses the drafters' conception of childhood and asks how it contributes to the understanding of what children's right to development can mean. This course of analysis does not aspire to flush out the 'true' intentions of the drafters or the 'true' meaning of the right under the Convention, ${ }^{4}$ not least because I do not argue that there is a singular 'true' meaning.

The previous chapter has established that one of the main aims of international children's rights law, and of legal theories concerning children's rights in general, it to protect children's development. This chapter continues the historical review of the child's right to development and picks up from the point where the previous chapter has ended. The point of departure for this chapter is the first draft of the Convention, which was presented by Poland in 1978. The chapter then follows the entire drafting process of the Convention, and ends with the final text of the Convention, as adopted by the UN General Assembly on $20^{\text {th }}$ November 1989. The drafting process is presented chronologically in order to facilitate an understanding of the processes and progresses made during the creation of the Convention in general, and of the right to development in particular. Analysing the drafting process chronologically paints a complex picture, and enables to understand the motivations that led to the creation of this particular right in a specific point in time, as opposed to studying each right in isolation, detached from any historical or other context.

I take this line of analysis for two main reasons. First, as I argued in chapter one, the perception of children as developing human beings and the comprehensive protection for their development were key components of international children's rights law before the creation of the Convention. Therefore, I assume that the Convention's drafters not only shared the conviction for the need to protect children's development, but that they also

\footnotetext{
${ }^{4}$ See Ronald Dworkin, 'Law as Interpretation' (1982) 9 Critical Inquiry 179, 196-199; Stanley Fish, 'Working on the Chain Gang: Interpretation on the Law and in Literary Criticism' (1982) 9 Critical Inquiry 201. See also Dennis Patterson, Law and Truth (Oxford University Press, Oxford 1996) 71-127.
} 
understood the practical implicationsof transforming this idea into a human right. The right to development is presumed to have been included in the Convention for a good reason, although it is neither explicitly protected in any of the previous international declarations on children's rights nor in any 'general' human rights treaties. Therefore, the travaux préparatoires should shed light on the drafters' intentions and their understanding of the right, and can serve as a valuable source in assessing the scope and practicality of this right.

The second reason is derived from the law of treaty interpretation. The Vienna Convention on the Law of Treaties ${ }^{5}$ is the positive source for justifying analysis of the travaux préparatoires. Article 31 of the Vienna Convention declares that treaties should be 'interpreted in good faith in accordance with the ordinary meaning to be given to the term of the treaty in the context and in the light of its object and purpose'. ${ }^{6}$ The Vienna Convention also mandates that 'a special meaning shall be given to a term if it is established that the parties so intended'? According to Article 32, other sources such as 'preparatory work of the treaty' can be used in the interpretation process, together with the text of the treaty itself. Moreover, even before the adoption of the Vienna Convention, travaux préparatoires was a valid source for interpretation, though there was no rule-of-thumb concerning the validity of referring to the preparatory work. ${ }^{8}$

The travaux préparatoires includes, according to Lord McNair, a former judge of the International Court of Justice, 'all the documents, such as memoranda, minutes of conferences and drafts of the treaty under negotiation'. ${ }^{9}$ This is not a definitive list. First, it is hard to determine the scale of these documents; and second, while McNair's definition emphasizes the information that is available on record, some diplomatic negotiations

\footnotetext{
${ }^{5}$ Vienna Convention on the Laws of Treaties (Done at Vienna on 23 May 1969, Entered into Force on 27 January 1980). United Nations Treaty Series, Vol. 1155, 331.

6 Article 31(1). See Francis G. Jacobs, 'Varieties of Approach to Treaty Interpretation: With Special Reference to the Draft Convention on the Law of Treaties before the Vienna Diplomatic Conference' (1969) 18 International and Comparative Law Quarterly 318, 343.

${ }^{7}$ Article 31(4).

8 Lord McNair, The Law of Treaties (Oxford University Press, Oxford 1961) 411. Martin Riss, 'Treat Interpretation and ICJ Recourse to Travaux Préparatories: Towards a Proposal Amendment of Articles 31 and 32 of the Vienna Convention on the Law of Treaties' (1991) 14 Boston College International \& Comparative Law Review 111, 116. See also Richard A. Falk, 'On Treaty Interpretation and the New Heaven Approach: Achievements and Prospects' (1967-1968) 8 Virginia Journal of International Law 323; For a critique on these approaches see Ian Johnstone, 'Treaty Interpretation: The Authority of Interpretive Community' (1990-1991) 12 Michigan Journal of International Law 371.

${ }^{9}$ As quoted by Riss, ibid, 112.
} 
concerning an international treaty also being done orally, ${ }^{10}$ and therefore are not part of the formal documentation of the negotiations.

This chapter is based on materials available at the UN Archive in Geneva, including the original draft of the Convention; summary of the Open-Ended Working Group's (the forum composed of diplomats and professionals from Non Governmental Organisations(NGO's) and UN agencies that drafted the Convention) meetings; and various memoranda and suggestions that were submitted to the Working Group before, during and after each drafting session, by UN agencies and NGO's. The chapter systematically analyses all of the OpenEnded Working Group's report. However, as lengthy as the reports are, and some of them are hundreds of pages long, they nevertheless are summaries, and not protocols, of the OpenEnded Working Group's meetings. Thus, they provide only a selective account of the debates and the information and conclusions that can be drawn from them are necessarily limited.

If the interpretation method in this chapter needs to be classified, it most closely follows the Teleogical School, since it will give effect to the 'object and purpose of a treaty'. ${ }^{11}$ This approach refers to both the text and the intentions of the drafters. Subsequently, this chapter refers to the drafting process of Article 6, as well as the other articles in the Convention that refer to children's development.

The primary finding of this chapter is that the drafting process included very few substantive discussions on either the right to development or the perception of children as developing human beings. Although both terms (mainly 'development' and to lesser degree 'the right to development') were used consistently throughout the process, their meanings were rarely discussed. Though the drafters often mentioned the need to protect children's development, they did not elaborate on the content of this suggestion, choosing instead to focus on ancillary questions such as the cost of 'development', or the division of responsibilities between parents and the state in relation to children's development.

I argue that the main reason for this gap is the drafters' perceptions of children as future adults, and the desire to provide legal protection to this hypothetical future. I further argue that despite the lack of attention given to 'the right to development' during the drafting process, it is possible to unlock the potential of Article 6 and to draw conclusions about the potential meanings of the right to development.

\footnotetext{
${ }^{10}$ Riss, supra n. 8, 112.

${ }^{11}$ Ibid, 115 and references there.
} 


\section{'We Should Have a Convention on the Rights of the Child' - The First Draft of the} Convention

In 1976, the UN General Assembly decided to commemorate the 30 year anniversary of the 1959 UN Declaration on the Rights of the Child by declaring 1979 the 'International Year of the Child. ${ }^{12}$ The Government of Poland believed that this was the right time to advance the idea of adopting a convention on children's rights. On 17 January 1978, Ambassador Eugeniuz Wyzner of Poland submitted to the UN Commission on Human Rights a draft for a Convention on the Rights of the Child, asking that the draft be brought before the Commission during its $34^{\text {th }}$ session. ${ }^{13}$ Eleven years later, in 20 November 1989, the General Assembly adopted the Convention.

The draft was based on the 1959 Declaration of the Rights of the Child and included twentyeight articles. The first ten articles were dedicated to substantive rights of children, while the remaining eighteen articles referred to procedural and technical aspects of an international treaty. Poland also submitted an Explanatory Memorandum elucidating its motivations for introducing the Convention, ${ }^{14}$ arguing that the 1959 Declaration 'played a significant part in the assistance, care and the rights of children' around the world, including 'shaping various forms of the international co-operation in this sphere'. Poland further argued that the care for children and their rights should not lag behind 'the collaboration of the international legal order in other spheres'. Therefore, adopting such a convention would be the appropriate way to celebrate the coming international year of the child. ${ }^{15}$

The 'question on a Convention on the Rights of the Child' was item number 22 on the Commission on Human Rights' agenda on 13 February $1978 .{ }^{16}$ Mr. Keba M'Baye, then the Chairperson of the Human Rights Commission, will later play a key role in creating the right to development in 'general' international law. ${ }^{17}$ The Commission held a short discussion about Poland's suggestion and decided to ask the Economic and Social Council to proceed with the process of adopting the suggested convention. ${ }^{18}$

\footnotetext{
12 General Assembly Resolution 31/169, 'International Year of the Child' adopted on 21 December 1976.

${ }^{13}$ UN Economic and Social Council (18 January 1978) UN Doc E/CN.4/1284.

${ }^{14} \mathrm{UNHCHR}$, Legislative History of the Convention on the Rights of the Child, Volume I (New York and Geneva 2007) 31 .

15 Ibid.

${ }^{16}$ UNHCR, 'Summary Record of the $1438^{\text {th }}$ Meeting' (15 February 1978) UN Doc E/CN.4/SR.1438.

17 See chapter five.

${ }^{18}$ UNHCR, 'Question of a Convention on the Rights of the Child' (7 February 1978) UN Docs E/CN.4/L.1366.
} 
The Economic and Social Council accepted the Commission's recommendation, ${ }^{19}$ and asked the General Assembly to consider adopting a convention on the rights of the child. ${ }^{20}$ One of the reasons for this decision was the Commission's awareness of the 'special need to assist children in the developing countries in a manner consistent with the goals of the new international economic order' ${ }^{21}$ This comment is one of the few comments made during the entire drafting process of the Convention that suggests some kind of awareness to developmental policies that tackle poverty and other economic disadvantages. Nevertheless, this comment refers to the public policy idea of 'development', and not to the right to development. The differences between these concepts are discussed in chapter five.

This decision of the Economic and Social Council marks the beginning of the Convention's drafting process. Following this decision, a group of twenty one NGO's submitted a long list of concerns about the proposed Convention. Although in principle the group welcomed the new convention, it asked to postpone its adoption until further studies concerning the implementation of the 1959 Declaration, due in 1980, had been completed. ${ }^{22}$ Following these requests, as well as some more comments, Poland submitted a revised draft of the Convention, which included changes only in relation to technical issues. ${ }^{23}$

In 7 March 1978, the UN Commission on Human Rights held another meeting on the topic. ${ }^{24}$ Most of the discussion was dedicated to the question of timing rather than content, and arguments were made for and against adopting the convention in 1979. Very few speakers referred to the human rights mentioned in the draft. Nevertheless, one very important comment was made by the representative of Syria, Sheikh Fadli:

'The protection of the child should be one of the prime objectives of a social and economical development strategy. The creation of a social climate favourable to the child would perhaps eliminate some of the problems which were obstacles to the right to development... The privileged children had a right to leisure and to the full development of their personality, and to be protected against violence, cruelty, exploitation, drugs and the slave trade, while the underprivileged children of developing societies had the right to life, to their daily bread, to shelter and to

\footnotetext{
${ }^{19}$ Ibid.

20 UNHCR, 'Question on a Convention on the Rights of the Child' (6 February - 10 March 1978) UN Doc E/1978/34/E/CN.4/1292, p. 4.

21 Ibid.

22 UN Economic and Social Council, 'Question of A Convention on the Rights of the Child' (23 February 1978), UN Doc E/CN.4/NGO/225.

${ }^{23}$ UNHCR, 'Question on a Convention on the Rights of the Child' (6 February - 10 March 1978), supra n. 20.

${ }^{24}$ UNHCR, 'Summary Record of the $1471^{\text {st }}$ Meeting', supra n. 1. The discussion concerning the convention on the rights of the child is taken from agenda item 22, supra n. 22.
} 
protection against underdevelopment. Only through international solidarity could children be properly protected. ${ }^{25}$

This is the first and nearly the last instance where any of the drafters used the term 'right to development'. In this comment, Fadli portrayed a relatively clear vision concerning the Convention's aims and the unique role that the right to development should have in relation to these aims. Fadli highlighted the differences in life experiences between children of different societies and consequently, the differences in their statuses of development. Fadli saw the opportunity for the Convention to create an international framework for cooperation, which could be used to change this unequal reality. Unlike most of the comments concerning development made thus far in the process of creating international children's rights law (in relation to the 1959 Declaration, for example), as well as those that would be made later, Fadli did not focus on psychological development, nor did he only refer to an individual child's process of development, but rather addressed the social and economic conditions that to a large extent dictate children's daily life. Linking two dimensions of development - the individual and the social - Fadli argued that the latter influences the former and creates the necessary conditions for it to occur. This comment did not get the attention it deserves, and from this point on, psycho-social development underpinned the drafters' perception of children's development.

Another round of comments was held in December $1978 .^{26}$ Some commentators addressed the issue of 'development', but none made any substantive comment about it. Bulgaria, for example, argued that some of the principles embodied in the 1959 Declaration were not implemented, including the principle that related to child labour, "which are injurious to the health of children and prevent their proper development'. ${ }^{27}$ France made a comment on Article 7 of the draft, which protected the child's rights to education and leisure time. According to France, the draft should be amended in a way that does not limit the protection given to children's play time, because 'while educational games are to be encouraged' the French delegate argued, 'they should not be the only ones the child can play. For his full

\footnotetext{
${ }^{25}$ UNHCR, Summary Record of the $1471^{\text {st }}$ Meeting, supra n. 1 .

26 UNHCR, 'Question of a Convention on the Rights of the Child' (1 February 1979) UN Doc E/CN.4/1324/Add. 1.

${ }^{27}$ Ibid, 5 .
} 
development, he [the child] also needs to involve himself in activities which are not necessarily part of a specific educational system' ${ }^{28}$

A number of non-governmental organizations and UN agencies made some more useful comments. $^{29}$ The United Nations Educational, Scientific and Cultural Organization (UNESCO) claimed that the draft did not 'accord sufficient importance to the right of the child to cultural development', and therefore recommended that the convention include broader protection of the rights to education and cultural identity. These rights, UNESCO argued, should include, inter alia, the right of the child to be educated in respect to human rights and providing adults with children's rights training. ${ }^{30}$ The World Health Organization (WHO) expressed concern about the level of protection provided to children's well-being, arguing that despite the binding nature of the Convention, the current draft might weaken the protection given to children's rights by the 1959 Declaration. To overcome this fault, the WHO asked to add an explicit and detailed provision concerning the 'obligations of parents, both as individuals and as couples, of the family and the society, particularly in relation to the protection of the child growth and development in its threefold dimensions: physical, mental and emotional. ${ }^{31}$ The International Association of Youth Magistrates endorsed the draft for the 'well-formulated catalogue of minimum conditions for the mental, physical and educational well-being of the child'. ${ }^{32}$

These comments mix terms, such as 'development' and 'well-being', without differentiating between them or between different features of development. Consequently, no coherent conception of what children's 'development' might mean can be drawn from these comments. 'Development' was addressed in relation to different articles and rights of the Convention, but not as a human right in and of itself. Nevertheless, wide support for the idea of adopting a Convention on the Rights of the Child led to the establishment of an OpenEnded Working Group, which was given the task of drafting the convention. The Working Group held its first meeting in February and March 1979.

\footnotetext{
${ }^{28}$ Ibid, 7-8.

${ }^{29}$ General comments by specialized agencies on the first Polish draft - annexed to Commission on Human Rights resolution 20 (XXXIV) of 8 March 1978 (27 December 1978) UN Doc E/CN.4/1324.

${ }^{30}$ Legislative history, supra n. 14, 64.

${ }^{31}$ Ibid, 64-65.

${ }^{32}$ Ibid, 65 .
} 


\section{Round of Discussions ${ }^{33}$}

This preliminary round of discussions was primarily dedicated to general discussions about the Convention, and less about the specific articles it includes. Nonetheless, the care for 'children's development' was raised few times, indicating just how significant this issue is going to be.

Several delegates stated that attention should be given to 'the status of children in developing countries suffering from malnutrition, hunger or poverty'. ${ }^{34}$ Similar concerns were mentioned throughout the entire drafting process, and were often linked to the status of children's development. In similarity to the 1924 Declaration, the proposition was that malnutrition, hunger and poverty were three conditions that not only jeopardized children's lives, but also had an impact on children's future.

In October 1979, following the comments made during the discussions, Poland submitted a third revised draft of the Convention. In this draft, children's development was referred to in different ways under six articles (Articles 3, 9, 13, 15, 17 and 19). The article reads:

Article 3(2)

'The States Parties to the present Convention undertake to ensure the child such protection and care as his status requires, taking due account of the various stages of his development in family environment and in social relations, and, to this end, shall take necessary legislative measures.'

\section{Article 9}

'Parents, guardians, State organs and social organizations shall protect the child against any harmful influence that mass media, and in particular the radio, film, television, printed materials and exhibitions, on account of their contents, may exert on his mental and moral development.'

\section{Article 13(1)}

'It is recognized that the child shall be entitled to benefit from the highest attainable standard of health care for his physical, mental and moral development, and also, in the case of need, from medical and rehabilitation facilities'.

\footnotetext{
${ }^{33}$ UNHCR, 'Report of the Open-Ended Working Group on a Draft Convention on the Rights of the Child' (12 March 1979) UN Doc E/CN.4/L.1468.

${ }^{34}$ Ibid, 2.
} 


\section{Article 15}

'1. The States Parties to the present Convention recognize the right of every child to a standard of living adequate for his healthy and normal physical, mental and moral development in every phase of the child's development.

2. The parents shall, within their financial possibilities and powers, secure conditions of living necessary for a normal growth of the child...'

\section{Article 17(1)}

'The States Parties to the present Convention recognize that the bringing up and education of the child should promote the full development of his personality, his respect for human rights and fundamental freedoms.'

Article 19(2)

'The States Parties to the present Convention recognize that the child shall not be employed in any form of work harmful to his health or his moral development, or in work dangerous to his life or which would interfere with his normal growth..., 35

These Articles indicate the drafters' approach toward children's life, development and human rights. One Article considers the child's stage of development while in care. Other two Articles seek to ensure that an adequate standard of living will be provided to children, and dictate that the aim of education is to promote the full development of the child's personality. Two of the Articles are concerned with the child's 'normal growth'. Three aspects of development are mentioned: mental, moral and physical development. In addition, two qualitative processes of development are mentioned: healthy and non-healthy ones.

The terms 'development' and 'normal growth' are used alternately without distinguishing between them. Presumably, both terms are used to describe the same utopian future that the drafters sought to create for children. The Articles signify a clear aim for the Convention to take the child's future as an achievable and desirable goal explicitly referring to specific domain of development. However, reading these Articles together does not give a sense of what such a future should look like, on top of transforming the child into an adult. This perspective about childhood and the aim of the Convention did not change throughout the drafting process, and this vagueness was not ever fully refined.

\footnotetext{
35 All emphasis added.
} 
From this point in time and until the drafting process ended, the Open-Ended Working Group held annual sessions. In every session the Working Group debated various versions of each right and each article, and at the end, the group's Chairperson published an official report that summarising the session.

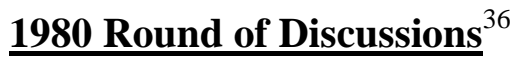

The third Polish draft was at the centre of this round of discussions. The debates evolved around the questions of defining the 'child', the references ought to be given to the 1924 and 1959 Declarations in the Convention's preamble, parental responsibilities and the right of the child to a name. Questions related to children's development were not raised in this round of discussions, and a right to development was not mentioned either.

\section{$\underline{1981}$ Round of Discussions $^{37}$}

The Working Group dedicated this session to a comprehensive review of the Convention's draft. Though all of the rights included in the draft were mentioned by name, in similarity to the previous round of discussions, children's development was not singled out as an issue worth debating. The Working Group's silence on this issue could be a result of many factors, ranging from lack of time, to more substantive reasons, such as lack of interest. Therefore, I am cautious in drawing any conclusions at this stage.

\section{$\underline{1982}$ Round of Discussions $^{38}$}

This session was dedicated to discussing Articles 6, 9, 10, 11 and 12 of the Convention's draft, which protect the right to parental care and family environment, the right of children who seek refuges status or were recognised as refugees, and the rights of children with disabilities. In addition, discussions were held with regard to some new Articles that were

\footnotetext{
${ }^{36}$ UNHCR, 'Report of the Working Group on a Draft Convention on the Rights of the Child' (10 March 1980) UN Doc E/CN.4/L.1542.

${ }^{37}$ UNHCR, 'Report of the Working Group on a Draft Convention on the Rights of the Child' (17 February 1981) UN Doc E/CN.4/L.1975.

${ }^{38}$ Legislative history,supra n. 14, 94. UNHCR, 'Report of the Working Group on a Draft Convention on the Rights of the Child' (8 March 1982) UN Doc E/CN.4/1982/30/Add. 1.
} 
suggested. These Articles protect the child's right to freedom of movement, right to privacy, right to freedom of thought, conscience and religion, and the right to freedom from abuse. ${ }^{39}$

The debate of Article 9 (right to information) marked the first substantive discussion on 'children's development'. A few delegates expressed concern that 'too much' information might jeopardise children's naivé and, therefore, 'States Parties to the Convention should have the obligation to protect children against any harmful influence that the contents of mass media may expert on their mental and moral development' ${ }^{40}$ The Holy See shared these concerns but also suggested adding 'spiritual and social development' to this list of developmental domains that might be in danger. ${ }^{41}$

In these comments, the drafters took for granted the alleged perils of mass media and echoed a common social panic of the time that a 'flood' of information could bring 'childhood' to an end. ${ }^{42}$ In other words, that some kind of information could jeopardise the 'development' of the child and thus bring to an end a specific image of childhood.

The discussion about Article 10 and the right of children with disabilities was informed by the apprehension for the future of these children. For example, the Canadian delegate, with the support of Australia, asked to include in the Convention a right to 'special protection and care' that 'will ensure him [the child] the right to enjoy a decent life, as normal and full as possible...'. The Canadian delegate further suggested including protection for the right of disabled children to employment, which would be 'designed to achieve the child's fullest possible social integration'. ${ }^{43}$ Such a comment acclaims the need to protect children's future ('decent life') and make an effort to design this future according to one moral standard 'normal' and 'full'.

\footnotetext{
${ }^{39} \mathrm{Ibid}, 71-72$.

${ }^{40} \mathrm{Ibid}$, 57. Emphasis added.

${ }^{41} \mathrm{Ibid}, 58$

${ }^{42}$ Neil Postman warned that exposing children to the mass media and to floods of information would bring childhood to an end. Neil Postman, The Disappearance of Childhood (Vintage Books, New York 1984).

${ }^{43}$ UNHCR, 'Report of the Working Group on a Draft Convention on the Rights of the Child' (8 March 1982), supra n. 38, 69-70.
} 


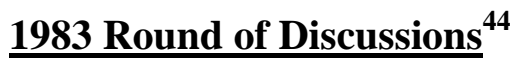

The 1983 session focused on the rights of children separated from their parents (Article 6), the right to freedom of thought, conscience and religion (Article 7), and the rights of children with disabilities (Article 12).

Only the debate concerning Article 12 and the rights of children with disabilities raised the issue of child's development. The travaux préparatoires tells us that 'several delegates supported the view that wherever assistance is extended to a disabled child, it should be provided in a manner most conducive to that child's social integration and individual development'. ${ }^{45}$ Canada was very active in this debate, suggesting the addition of another clause concerning the services that children with disabilities should be entitled to:

'...3. Assistance extended shall be designed to ensure that the disabled child has access to and receives education, training, health care services, rehabilitation services, and preparation for employment, and enjoys recreation opportunities, in conditions most conducive to the child's fullest possible social integration and individual development'.

'4. The disabled child's special education needs and rehabilitation needs shall be provided in a manner most consistent with realizing the child's fullest potential .... 46

In congruence with previous suggestions, these clauses also used the terms 'development' and 'fullest potential' alternatively, this time perceiving them as the aims of ensuring the disable child's rights.

Australia submitted a similar amendment, which included a commitment to achieve the 'fullest possible social integration' to children with disabilities, but it omitted the commitment to the child's individual development. ${ }^{47}$ The discussion on these suggestions resulted in 'no agreement' with regard to 'the insertion of such a clause'. ${ }^{48}$

Later in the meeting, Canada revised its amendment. The new version included protection for more aspects of child's development, so these children will be able to achieve 'the fullest

\footnotetext{
${ }^{44}$ UNHCR, 'Report of the Working Group on a Draft Convention on the Rights of the Child' (25 March 1983) UN Doc E/CN.4/1983/62.

${ }^{45} \mathrm{Ibid}, 14$.

${ }^{46} \mathrm{Ibid}, 15$. Emphasis added.

${ }^{47}$ Ibid.

${ }^{48} \mathrm{Ibid}, 14$.
} 
possible social integration and individual, cultural and spiritual development'. ${ }^{49}$ This proposition added support for the child's 'cultural and spiritual' development on top of the promise for 'individual' development. However, why there was a need to emphasis these two components in particular over other potential developmental components. The travaux préparatoires does not shed light on this question.

After further discussion, an agreement for the text of article 12(3) was reached. The agreed version aimed to facilitate services that would be designed to enable the disabled child to achieve 'the fullest possible social integration and individual development, including his cultural and spiritual development, ${ }^{50}$

This version still suffered from the same ambiguity as the previous versions. It combined the child's potential and two developmental aspects intrinsic to the child, with social integration as an external dimension. It linked cultural and spiritual development as necessary ingredients to social integration and individual development, but it did not adequately clarify why or how this might happen. Nor did this version clarify the relationship between child's development and supporting the realisation of the child's fullest potential.

\section{Round of Discussions ${ }^{51}$}

This round of discussions focused on right to freedom of thought, conscience and religion (Article 7(bis)), the right to be protected from abuse (Article 8(bis)), the right to freedom of information (Article 9), and the right to social security (Article 13).

In similarity to previous rounds, Article 9 and the right to freedom of information stimulated a heated debate in general and regarding its potential impact on 'development' in particular. Poland suggested amending article 9 to include the following protection:

'...The States Parties shall also encourage parents and guardians to provide their children with appropriate protection if, on account of its contents, the disseminated information might negatively affect the physical and moral development of the child, ${ }^{52}$

\footnotetext{
${ }^{49} \mathrm{Ibid}, 16$. Emphasis added.

${ }^{50} \mathrm{Ibid}, 17$. Emphasis added.

${ }^{51}$ UNHCR, 'Report of the Working Group on a Draft Convention on the Rights of the Child' (23 February 1984) UN Doc E/CN.4/1984/71.

${ }^{52} \mathrm{Ibid}$, 11. Emphasis added.
} 
Thissuggestion generated a debateabout media regulation, flow of information within state's borders and between states and state's intervention in disseminating content. However, no comments were made regarding the underlying assumption that some type of information could have a negative impact on the child's physical and moral development. Consequently, no discussion was held regarding the phrases 'physical and moral development'.

Two revised versions of Article 9 were then submitted, one by an ad-hoc informal drafting group and the second by Ukrainian SSR. Child's development was omitted from both versions. The ad-hoc group's version replaced the care for 'development' with care for the child's 'social, spiritual and moral well-being and physical and mental health', ${ }^{53}$ while the Ukrainian SSR's version asked to promote 'the health and welfare of the child, his social and cultural upbringing, ${ }^{54}$ In addition, this version asked to protect the child 'from material injuries to his physical or mental health or to his social, spiritual or moral well-being, ${ }^{55}$

These two versions demonstrate once again the lack of distinction between 'development', 'well-being', and 'upbringing'. There are three possible explanations for the use of these terms: The first is lack of difference between them; the second is lack of attention to these differences; and the third is a situation where these four terms have different meanings, and a conscious choice has been made to use them alternately. However, since no explanation was given concerning this choice of words, the last option seems most unlikely. Nonetheless, what can be inferred is the common desire of all drafters to protect the course of children's growth and ensure some sort of an imaginary optimum result.

More discussions followed, and the USA and Ukrainian SSR jointly suggested a new version for this article. It read:

'The States Parties recognize the important function performed by the mass media and shall ensure that the child has access to information and material from a diversity of international and national sources, including those aimed at the promoting of his social, spiritual and moral well-being and physical and mental health...'.56

None of the comments that followed, except for one made by the UK, were related to development, to children's well-being or to children's upbringing. The UK referred to the

\footnotetext{
${ }^{53} \mathrm{Ibid}, 12$. Emphasis added.

${ }^{54}$ Ibid. Emphasis added.

${ }^{55}$ Ibid, 13. Emphasis added.

${ }^{56}$ Ibid, 14. Emphasis added.
} 
distinction between well-being, and upbringing, arguing that 'anything injurious to a child's physical and mental health would be injurious to his well-being also. ${ }^{, 57}$ Thus, the UK argument presented a pyramid, where mental health and physical health are the foundations, while well-being is placed on top of the pyramid. This structure identifies 'well-being' as the ultimate object of protection of this Article.

While the pyramid analogy sheds some light on the drafters' understanding of these terms, it does not sufficiently clarify whether 'well-being' is identical or similar in any way to 'development', or whether 'good health' lays the foundation for the process of achieving good 'well-being'.

\section{Round of Discussions ${ }^{58}$}

The 1985 round of discussions saw extensive and lengthy discussions about children's development. The Working Group discussed children's right to health (Article 12), right to an adequate standard of living (Article 14), right to education (Article 15), the aims of education (Article 16), and the right to rest and leisure (Article 17).

Article 12 addresses the right to health of children. In the first drafts that were debated, the Article did not mention 'development' as an aim for ensuring children's health. However, after long discussions that touched upon questions of health care funding and how accessible health services should be for children, an NGO Ad-Hoc working group suggested adding an additional paragraph:

'The States Parties to the present Convention shall undertake to protect children from any medical investigation or treatment detrimental to their physical or psychological health and development, and to take all appropriate and necessary measures to prevent children being subject to traditional practices harmful to their health, 59

This terminology suggests a desire to protect children's 'physical or psychological' development from 'medical investigation or treatment' that might put them at risk. Unlike other clauses, this clause does not provide for active promotion of development, but rather, establishes negative protection against actions that might put the child's 'physical or

\footnotetext{
${ }^{57} \mathrm{Ibid}, 16$.

${ }^{58}$ UNHCR, 'Report of the Working Group on a Draft Convention on the Rights of the Child' (11 March 1985) UN Doc E/CN.4/1985/L.1.

${ }^{59} \mathrm{Ibid}, 8$. Emphasis added.
} 
psychological health and development' at risk. The Article does not link development and the general right to health, and is confined to a narrow aspect of health.

The second half of the paragraph mentions traditional practices and takes them to be harmful to children's health, but it does not link these practices to children's development. Such a link would be made later in the drafting process. The discussion that followed this suggestion did not touch upon any of these concerns, nor did it mention 'development'.

The debates about Article 14 and the right to an adequate standard of living are of great importance. The discussions were based on a text proposed by the NGO Ad-Hoc group, which reads as follows:

'The States Parties to the present Convention recognize the right of every child to a standard of living adequate to guarantee the child's physical, mental, moral and social development. The parent(s) or those responsible for the child have the primary responsibility to secure, within their financial possibilities and powers, the conditions of living necessary for the healthy development of the child. ... ${ }^{, 60}$

There are different ways to read this article. It can be read to protect two standards of living, rather than only one. The first standard is protected by a general right to an adequate standard of living, which guarantees the first four elements of the child's development. The second standard ought to ensure a fifth element of development, the 'healthy' development of the child, which is the sole responsibility of parent(s) to ensure. There is also the possibility that the drafter did not think of these as two different standards, and took 'healthy' development to have the same meaning as 'physical, mental, moral and social' development. Another possible explanation for this division is not the difference between the meaning of these developmental domains, but rather the desire to differentiate between the obligations of states and of parent(s). If this later possibility is the case, it seems that less attention was given to the content of the obligation vis-à-vis the child's development, compared to the different levels of obligations imposed on states and parents.

Despite the fact that the drafters had a relatively lengthy discussion on this right, the travaux préparatoires does not shed much light on these questions. Only the Holy See referred to the question of development, when it asked to add 'spiritual' development to the list of

${ }^{60}$ Ibid. Emphasis added. 
developmental components that should be protected by the child's standard of living. ${ }^{61}$ This suggestion was rejected. ${ }^{62}$

The wording of this clause tells us that the list of children's developmental domains is not a closed list, but depends on one's perception of 'the child' and of 'development'. But since the drafters ignored these questions, no definitive answers can be deduced.

The discussions on the right to education and on the aims of education (Articles 15 and 16 of the draft, respectively) generated some debates about the issue of children's development as well. According to Article $15,{ }^{63}$ ensuring the child's right to education is needed in order to promote the child's 'talents and abilities to their fullest potential, and to prepare the child for future life'. ${ }^{64}$ This clause does not address an abstract process or any components of development, but rather focuses on two specific dimensions of the process of growing up: talent and abilities. The Article articulates a forward looking aim of education, which is designed to generate the creation of maximum talent for each individual chid. The drafters further debated the issues of the cost of education, whether children should be entitled to free education and if so, for what period of time, and whether state's financial resources should be taken into account in either formulating their obligations or in implementing them. Other discussions touched upon the issues of rights and duties of parents to ensure their children's education, and the duties of international cooperation with respect to education. ${ }^{65}$

The aims of education were discussed in relation to Article 16. The Working Group debated five versions of Article 16, two of which refer to children's development. The first was the Canadian version that defined the aim of education to promote the development of the child's personality, talents and abilities to their fullest potential...' ${ }^{66}$ The second version, introduced by the Baha'i International Community, includes much broader objectives for education:

'in addition to academic education, the child shall be entitled to receive guidance, training and education designed to promote his social, spiritual and moral development and well-being. The fundamental objectives of such guidance, training and education shall be (a) to promote the harmonious

\footnotetext{
${ }^{61}$ Ibid, 9.

${ }^{62}$ Ibid.

63 'The States Parties to the present Convention shall guarantee to every child compulsory and cost-free education, at least at elementary school level, designed to assist the child to develop his or her talent and abilities to their fullest potential, and to prepare the child for future life....'. Ibid, 11.

${ }^{64}$ Ibid.

${ }^{65} \mathrm{Ibid}, 11-15$.

${ }^{66} \mathrm{Ibid}, 16$.
} 
development of the personality of the child and the realization of his full potential..., 67

While the Canadian version used familiar terms such as 'talent' and 'fullest potential', the Baha'i's version introduced several new ideas and terms. It took development and well-being as two complementary but nevertheless distinct terms. This version preferred to have the child's 'harmonious development' promoted instead of promoting fractions of 'development'. It also aimed to create the conditions necessary to ensure the 'full potential' of the child. Unfortunately, the drafters were not impressed by the innovative nature of this suggestion and at the discussions that followed did not address the issue of the child's development at all. ${ }^{68}$

The end of this round of discussion left the term 'children's development' in a familiar state of conceptual ambiguity. The term 'development' was used by the drafters and different components of development were mentioned. But the drafters did not discuss the meaning or content of any of the terms, or explain their relevant, their connection or context. Even when the potential link between 'development' and 'well-being' was suggested, no attention was given to the meaning of such a link.

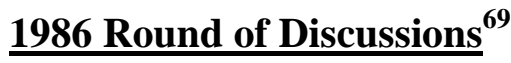

Almost a dozen rights were discussed during this session, including the right to nondiscrimination (Article 4(bis)), the right to leave the state (Article 6(bis)), the right to identity (Article 9(bis)), the rights of children who were removed from their family environment (Article 12(ter)), the educational and cultural rights of indigenous children (Article 16(bis)), the right to be protected from economic exploitation (Article 18), measures needed to be taken against usage of narcotic drugs (Article 18(bis)), the right to freedom of association and assembly (Article 18(quarter)), rights of children in the criminal procedures (Article 19), the rights of children in respect to international humanitarian law and during international armed conflict (Article 20) and the relationship between children's rights in domestic law and the Convention (Article 21). Most of these clauses explicitly refer to children's development, but

\footnotetext{
${ }^{67}$ Ibid.

${ }^{68}$ Ibid, $17-19$.

${ }^{69}$ UNHCR, 'Report of the Working Group on a Draft Convention on the Rights of the Child' (13 March 1986) UN Doc E/CN.4/1986/39.
} 
unlike the previous rounds, this time the Working Group did not address to the issue of 'children's development,' with two exceptions.

The first relevant debate to the issue of child's development took place as part of the discussions on Article 18, which addressed the protection of children from economic exploitation. Poland suggested a new text:

'The child shall not be employed in any form of work harmful to the child's health or education or which will interfere with his physical, mental or social development...' ${ }^{70}$

The drafters held an intensive debate about this version of Article 18. However, despite the alleged impact that any form of work might have on children's development, the reasons for such impacts were not discussed, let alone challenged. Only the Holy See referred to this issue and, as usual, seized the opportunity to suggest including 'spiritual' development to the list of developmental domains that might be put in dangerous due to economic exploitation. ${ }^{71}$

The next relevant discussion concerned Article 19, which protected the rights of children in the criminal justice system. Different versions of this article were submitted to discussion, and all were aimed at ensuring the child's rehabilitation. All the different versions reflected similar concerns regarding the impact that state's custody can have on the child's future. However, despite the obvious connection between these concerns with various developmental issues, including those already mentioned by the drafters, the different wording did not make any such connection, or even mentioned children's development as an object of concern.

Nonetheless, the versions that Canada and Poland presented mentioned children's level of development, as a factor that should be taken into account when realizing rehabilitation programmes. The Polish text reads as follow:

'...the child subject to penal procedures shall be treated in a manner commensurate with his phase of development, with his reformation and social rehabilitation in law, ${ }^{, 72}$

\footnotetext{
${ }^{70}$ Ibid, 13. Emphasis added.

${ }^{71}$ Ibid, 14.

${ }^{72}$ Ibid, 18
} 
And the Canadian version reads:

'State Parties to the present Convention recognize the right of children accused or found guilty of infringing the penal law to be treated in a manner... which takes into account their age and the desirability of promoting their rehabilitation, 73

These suggestions are the prototype for what would later become the principle of 'evolving capacities' of children in the Convention. Despite its significance, the drafters dedicated only a short discussion to them, with nothing substantial being said.

This round of lengthy discussion ended with 'development' on the margin of the debates. In comparison to previous rounds, the discussions in this round were exceptionally dull. 'Development' was either not an important enough issue to warrant discussion, or the drafters did not feel any need to address this issue. This ongoing disregarding from 'development' strengthens the conclusion that drafters shared the view that 'development' has a selfexplanatory meaning. The drafters did not think that there was a need to discuss the meaning of 'development', and simultaneously, they all thought that there is a need to protect 'development'. Thus far, no suggestion was made to refer to children's development as an issue of human rights.

\section{Round of Discussions ${ }^{74}$}

During this session, a dozen rights and issues were discussed, including how to encourage children to read books(Article 9), the rights of children in alternative care, protecting children from harmful traditional practices(Article 12), the aims of education, the educational rights of children belong to minorities or indigenous populations (Article 16), protecting children from sexual exploitation(Article 16(ter)), prevention of sale or traffic of children(Article 18(quinto)), parental rights and responsibilities(Article 5(bis) and Article 14), the right to freedom of expression and association (Article 7(ter)) and the right to privacy (Article 7(ter)). The term 'development' was repeatedly mentioned, but was not considered to be an issue deserving of attention or worth discussing. Nonetheless, some discussions do worth paying attention to.

\footnotetext{
${ }^{73}$ Ibid, 19.

${ }^{74}$ UNHCR, 'Report of the Working Group on a Draft Convention on the Rights of the Child' (23 February 1987) UN Doc E/CN.4/1987/25.
} 
The debate about the need and the measures required protecting children from economic and sexual exploitation continued in this session. France and The Netherlands suggested including in the Convention an article that would protect children from 'all forms of exploitation, particularly sexual exploitation, as well as against all degrading treatment and all acts prejudicial to the moral, spiritual, mental or physical integrity of the child. ${ }^{75}$ These words are remarkably similar to the language usually used in relation to children's development, with one significant difference. In this version, the object of concern is not children's development itself, but rather children's 'moral, spiritual, mental or physical integrity'. This is the first time that the term 'integrity' was used. Like 'well-being' or 'growth', it was used as a substitute for the term 'development'. But this new term is as ambiguous as the other terms, does not have a common meaning, nor does it provide a clearer definition for 'moral, spiritual, mental or physical' development. It is also not sufficiently clear what ideological baggage this term carries with it in relation to children's life and children's rights: how did the drafters understand it and whether they were in fact aware of any kind of different meaning that this term had compared to other terms? Once again, the travaux préparatoires does not provide answers to these questions.

Some delegates highlighted this opacity. The representative of the UK, for example, argued that this phrase was 'too vague and more precise meaning would have to be given to [it]' ${ }^{76}$ The representatives of the USA, Venezuela, France and the Netherlands (who introduced this version) further claimed that this wording 'had no substantive legal meaning in the United States and several other legal systems, and therefore could not be enforced' ${ }^{77}$ Eventually, the Working Group decided to replace the term 'integration' with the term 'welfare'. However, this change had little impact, since it did not resolve the fundamental problems regarding the meaning of this clause. 'Welfare', like 'integration', is at best a term calling for a definition and is open to interpretation. Thus, unlike 'integration' or 'well-being', 'welfare' is a term that has been long used in children's law and promoting children's welfare has been a long time aim of children's law. Nonetheless, welfare was rarely seen as a matter of human rights. $^{78}$

Another relevant discussion was held in relation to Article 5(bis), which deals with parental rights and responsibilities. The drafters debated the following text:

\footnotetext{
${ }^{75}$ Ibid, 16.

${ }^{76}$ Ibid, 17.

${ }^{77}$ Ibid, 22-23.

${ }^{78}$ See chapter one.
} 
'...parents or legal guardians shall enjoy the primary rights and responsibilities for the care, upbringing and development of the child, having due regard for the importance of allowing the child to develop the skills and knowledge required for an independent adulthood'. ${ }^{79}$

This text is one of the rare occasions where the drafters explicitly relate to the concept of childhood as they understand it. According to the text, the child is destined to grow up into 'an independent adulthood' and others have the responsibilities to facilitate this course of growth. The discussion that followed touched upon the narratives of children's future, children's development and the perception of children as developing human beings.

Canada argued that its support for this provision depends on giving 'due regard for the evolving capacities of the child and for the child's need to mature into an independent adulthood'. ${ }^{80}$ This comment is important for two reasons. First, it includes an explicit reference to a certain conception of childhood. Second, this comment presumes the evolving capacities principle as an inherent characteristic of children. In different words, the sense of development and changeare the profound characteristics of children. Taken together, the text and the comments create a relatively coherent picture of the drafter's conception of childhood: it is a process of maturation. In the end, the debate resulted in no decision being reached and the Working Group decided to postpone the conclusion to a later session.

The debate concerning Article 7(ter) and the right to freedom of expression, freedom of association and right to privacy generated several additional comments concerning the principle of evolving capacities. Reflecting its general stand during the Cold War era, the United States submitted a text that included comprehensive definition and protection for these rights. ${ }^{81}$ But nothing in the wording of that version either suggested that those rights should be restricted according to the child's stage of development, or aimed to facilitate the child's development. However, during 'a lengthy discussion', 82 the question of children's development did arise. The representative of Australia was the first to ask why the provision did not refer to 'the evolving sense of responsibility of children', 83 and Sweden made a similar claim, suggesting drafting 'a separate article on the evolving capacities of the child' ${ }^{84}$

\footnotetext{
${ }^{79}$ Ibid, 24.

${ }^{80}$ Ibid, 25.

${ }^{81}$ Ibid, 26.

${ }^{82}$ Ibid, 27.

${ }^{83}$ Ibid.

${ }^{84}$ Ibid.
} 
The representative of Norway supported the United States' version, but expressed concerns similar to those expressed by Australia, saying that there is 'a need for a general provision dealing with the evolving capacities of the child'. ${ }^{85}$ Canada and Argentina shared this view. The USSR and China objected to inclusion of these rights, claiming that the focus on political rights neglected other important interests of the child such as economic and social rights. The representative of China also referred to the evolving capacities argument, saying that 'the freedom of association, peaceful assembly and privacy could not be enjoyed by children in the same way as they are enjoyed by adults, because the intellect of a child was not as developed as that of an adult, and therefore a child could only engage in activities commensurate with its intellect'. ${ }^{86}$

The end of the 1987 round of discussions left the protection for children's development at a crossroads. On the one hand, protecting and promoting children's development were taken as the aims for many of the Convention's rights. The idea of children as developing human beings underpins the drafters' idea of childhood in two different ways: Development was either the expression of the process of growing up, or a point of reference in the form of 'the evolving capacities principle'. On the other hand, wide-ranging and alternative components of 'development' were being discussed, but the meaning or meanings of them were not addressed. A part of the failure to engage with the meaning of 'development' in itself was due to the fact that it was mixed with other concepts such as 'well-being', 'upbringing' and 'integrity'. But, since the drafters clarified none of these terms either, their potential connection to 'development' (similarity, completion of meanings, being a synonym, distinct meaning all together) was ignored as well.

After this round of discussions ended, the preparation for the next round began. At this stage, India submitted the following proposal for Article 1 bis (or 2 bis):

'The States Parties to the present Convention undertake to create an environment, within their capacities and constitutional processes, which ensure to the maximum extent possible, the survival and healthy development of the child, ${ }^{87}$

\footnotetext{
${ }^{85}$ Ibid.

${ }^{86}$ Ibid.

${ }^{87}$ UNHCR, 'Pre-Sessional Open-Ended Working Group on the Question of a Convention on the Rights of the Child, 'Proposal Submitted By India'’(28 January 1988) UN Doc E/CN.4/1988/WG1/WG.13.
} 
This was the first time that the terms survival and development were introduced as separate concepts, and were not attached to any other right. Having said that, this proposal attached the two concepts together and confined State's obligations only to the 'healthy development' of the child.

\section{$\underline{1988 \text { Round of Discussions }}{ }^{88}$}

The 1988 round of discussions was the one before last. During this round, the Working Group debated many of the Convention's rights, including the right to freedom of expression and information (Article 7a), the right to freedom of association and peaceful assembly (article 7ter), the right to privacy (Article 7quater), the right health (Article 12bis), the right to physical and psychological recovery and social re-integration (Article 14), and children's rights during armed conflicts (Article 20). Children's development was mentioned with respect to some of these rights, but none of the comments about it add more than what already known. I will focus on the debates concerning the proposal of India.

The proposal by India to adopt Articles 1(bis) or 2(bis) was discussed at length. These discussions were the first time since the drafting process had begun that the drafters directly discussed the meaning of 'development'. The drafters also discuss the definition of 'survival', explored the relationships between the concepts of 'survival' and 'development' and between these two concepts and the right to life. Due to the importance of these debates, I will quote from the travaux préparatoires at length.

'During the course of the debate' the travaux préparatoires reports, 'several governmental representatives commented that the concept of survival was not legally defined and one representative expressed the belief that it could even prove harmful to the concept of the right to development'. ${ }^{89}$ While these anonymous representatives were correct in their concern regarding the concept of survival, they did not make a similar claim with regard to the right to development. This omission can lead to the conclusion that these commentators had an understanding of what the right to development stands for. The debates that followed, in this round of discussions and the next one, prove this assumption wrong.

Following these comments, four different versions to the Article were proposed:

\footnotetext{
${ }^{88}$ UNHCR, 'Report of the Working Group on a Draft Convention on the Rights of the Child' (6 April 1988) UN Doc E/CN.4/1988/28.

${ }^{89} \mathrm{Ibid}, 5$.
} 
The first version:

'The States Parties to the present Convention shall respect the right of the child to survival. The States Parties shall, within their capacities and constitutional processes, take all necessary measures to ensure, to the maximum extent possible, the survival and healthy development of the child.'

The second version:

'The States Parties to the present Convention undertake to promote conditions which ensure, to the maximum extent possible, the survival of the child.'

The third version:

'The States Parties to the present Convention undertake to create within the available resources the psychosocial conditions which will guarantee, to the maximum extent possible, the life and the full development of the child.'

And the fourth version:

'The States Parties to the present Convention undertake to promote conditions which guarantee the life and healthy development of the child. ${ }^{, 90}$

There are several similarities and few differences between these four alternatives. First, child's development is mentioned only in three of them. Second, two different adjectives are used to describe what sort of 'development' should be ensured by this article - it is either the child's 'healthy' development, or the child's 'full' development. Third, one of the versions presents an obligation to ensure the child's 'full development', which should be facilitated by guaranteeing the 'psychosocial conditions' for this type of development. No other clearer or more coherent ideas can be found in any of these alternatives than can be found in India's original proposal.

The observer of UNICEF tried to explain the reason that lay behind these alternatives. She or he 'explained what the Fund [UNICEF] understood by survival'. ${ }^{91}$ Unfortunately, the travaux préparatoires does not elaborate on the content of this explanation. Nonetheless, following this unreported explanation:

\footnotetext{
${ }^{90}$ Ibid, 5-6. Emphasis added

${ }^{91}$ Ibid, 6.
} 
'the representative of India was of the view that the right to survival should be stressed, bearing in mind, as indicated by UNICEF, that many children died from preventable causes and that children could also survive in very poor conditions, the right to survival should be supplemented by the notion of healthy development'. ${ }^{92}$

In different words, India linked the right to survival with the right to life and the right to development, in order to ensure that the child could survive birth, the course of childhood, and to develop in a healthy manner.

At this point, the discussions 'focused mainly on the definition of the concepts of survival, right to survival, right to development and the child's development. The view was expressed that life and survival were complementary and were not mutually exclusive, and that survival could even mean the diminution of infant mortality'. ${ }^{93}$ Again, the travaux préparatoires provides no further details concerning the content of these discussions, except for the comments about the meaning of the right to development, which were expressed earlier. This is a surprising omission in light of the drafters' own concerns about the meaning or the 'right to development' at the beginning of the discussion. Moreover, since some parts of the travaux préparatoires includes lengthy discussions about the meaning of well-established rights such as freedom of expression or non-discrimination, it is only expected that when introducing a new right to the UN human rights treaties system, as many explanations (and maybe justifications) as possible will be provided.

Following this hazy discussion, the Italian representative offered to add to the Convention a provision concerning children's right to life. ${ }^{94}$ In response,

'it was stated that the right to survival carried with it a more positive connotation than the right to life, it meant the right to have positive steps taken to prolong the life of the child. The view was further expressed that conditions should be defined in order to permit the exercise of the right to life, and not the right to (mere) survival. Two speakers stated that despite the explanations that had been given on the word 'survival', they continue to have 'serious doubts about the inclusion of this concept in the convention'. 95

\footnotetext{
${ }^{92}$ Ibid.

${ }^{93}$ Ibid.

${ }^{94}$ Ibid, 7.

${ }^{95}$ Ibid.
} 
Two new versions for the article were introduced:

'The States Parties to the present Convention undertake to promote conditions which protect, to the maximum extent possible, the life of the child.'

and

'The States Parties to the present Convention undertake to promote conditions which ensure, to the maximum extent possible, the survival and healthy development of the child;

'States Parties shall protect the right to life of children and ensure the survival and healthy development of children. 96

For the first time, these proposals offered to include a right to life in the Convention. In similarity to the original Indian proposal, these suggestions included a protection for children's 'healthy development'. Nevertheless, none of these alternatives helps clarify the meaning of the right to development or the nature of the relationship between the rights to life, survival and development.

The travaux préparatoires concludes the discussion in these words:

'In summing up the debate, the Chairman-Rapporteur stated that the right to life had been omitted from the draft convention, and that the proposal made in working paper 13 was intended to remedy that shortcoming. The right to life, already enshrined in the International Covenants on Human Rights should be included in the draft convention and listed as a priority before other rights of the child. The approach to the right to life in the Covenants was rather negative, while that of the convention should be positive and should take into account economic, social and cultural conditions'. ${ }^{97}$

Following this concluding remark, an Ad-Hoc Drafting Group led by India introduced a new version for this clause:

'1. The States Parties to the present Convention recognize that every child has the inherent right to life.

2. States Parties shall ensure, to the maximum extent possible, the survival and development of the child. ${ }^{, 98}$

\footnotetext{
${ }^{96}$ Ibid. Emphasis added.

${ }^{97}$ Ibid.

${ }^{98}$ Ibid.
} 
According to India, this version aimed to meet the following concerns: '(a) the inherent right to life of the child, and (b) the focus on obligations for States parties to promote measures and conditions for the survival and development of the child. ${ }^{99}$ This explanation did not clear the ambiguity of either 'development' or 'survival', or the meaning of the relationship between the two. Presenting this version at this point in time was the embodiment of the 'becomings' model. There is no doubt that the perception of children as developing human beings and the need to ensure their course of growth was inherent to the drafters' visions of childhood, and therefore became a fundamental aim of the Convention.

The discussion about the Article continued, but focused primarily on the right to life. ${ }^{100}$ It ended with no further amendments to the text of the Article. ${ }^{101}$ The travaux préparatoires includes no further details regarding whether the drafters debated the meaning of the right to life, the right to survival and the right to development, the differences between the three and the pros and cons of including any of them in the Convention. Since the final version of the text is similar to India's original proposal, it is reasonable to assume that the discussions resulted in the drafters being satisfied with the original version and the explanations that followed. If this is the case, one can wonder whether the concerns some of the delegates expressed about the vague nature of the right to survival were met with convincing explanations. Another question is whether some of the draftershad a profound understanding of the meaning of any these rights, or their practical implications. The travaux préparatoires is silent about this point.

The next item of the Working Group's agenda was Article 5, which refers to the evolving capacities principle and parental responsibilities. ${ }^{102}$ Most of the discussion about this Article was dedicated to the latter issue, and only two comments were concerned with the evolving capacities principles. The first described the evolving capacities principle as an important general concept', ${ }^{103}$ while the second argued that the evolving capacities principle aims to ensure that children's rights are fulfilled 'in accordance with his [the child] age'. ${ }^{104}$ Similarly to the previous rounds of discussions, no further comments were made and there was no

\footnotetext{
${ }^{99}$ Ibid.

${ }^{100}$ Ibid.

${ }^{101}$ Ibid.

${ }^{102}$ Ibid, 7-9.

${ }^{103}$ Ibid, 8.

${ }^{104}$ Ibid.
} 
discussion concerning the content of the principle, let alone its justification, importance, implications for other rights or relationship with the right to development.

\section{Round of Discussions ${ }^{105}$}

The 1989 round of discussions was the final round of discussions, and by the end of it the Working Group had adopted the final version of the Convention.At this round, the Working Group discussed most of the Convention's rights, and children's 'development' was mentioned in relation to few of them. I will focus on the debates concerning the adoption of Article 6 and the rights to life, survival and development.

Two versions of Article 1(bis), which after a technical reading became Article $6,{ }^{106}$ were discussed in this final round. The first version was the one adopted at the end of the previous round of discussions. Venezuela presented a second version, which reads:

'1. For the purposes of the present Convention, 'child' means every human being up to the age of 18 years unless, under the law of his State he has attained the age of majority earlier.

2. The States Parties to the present Convention recognize that every child has the inherent right to life.

3. States Parties shall ensure to the maximum extent possible the healthy growth and development of the child. ${ }^{107}$

In this version, the protection for the child's 'healthy development' remained, but the right to survival was omitted and replaced with the term 'healthy growth'. Consistent with its position, the representative of the WHO objected to this change on the ground that 'the term "survival" had a special meaning within the United Nations context, especially for his organization and UNICEF.' 108 In an unprecedented manner, not only did the WHO representative provide a detailed explanation of the meaning of the term 'survival' for the organization, the explanation was also not omitted from the travaux préparatoires. According to the WHO,

105 UNHCR, 'Report of the Working Group on a Draft Convention on the Rights of the Child' (2 March 1989) UN Doc E/CN.4/1989/48.

${ }^{106}$ UNHCR, 'Draft Convention on the Rights of the Child, Working Paper Submitted by the Chairman, Text as Adopted at First Reading With Suggested Revisions' (24 November 1988) UN Doc E/CN.4/1989/WG.1/WP.2.

${ }^{107}$ Ibid, 17.

${ }^{108}$ Ibid. 
"Survival" included growth monitoring, oral rehydration and disease control, breastfeeding, immunization, child spacing, food and female literacy; the term "growth" represented only a part of the concept of "survival" and the change would be a step backwards from standards already accepted'. ${ }^{109}$

This explanation shed light on some of the drafters' understanding of the concepts of 'survival' and 'growth'. First, the usage of the term 'growth' and not 'development' in this context indicates the overlapping meaning of the two terms. Second, taking this broad interpretation of 'survival', this explanation raises questions concerning the difference between 'survival' and 'growth', and consequently between 'survival' and 'development'. Third, considering this comment and the other comments made during the previous rounds of discussions, the question of whether 'survival' has any added value over 'development' and if so, what does it mean, remains unclear.

Australia, Norway, Italy, Sweden and India expressed support for the WHO's interpretation,adding some substantial comments. Italy added that

'in the language of international organizations the two words "survival" and "development" had come to acquire the special meaning of ensuring the child's survival in order to realise the full development of her or his personality, both from the material and spiritual points of view'. ${ }^{110}$

This comment addresses some of the concerns mentioned earlier. According to this position, children's survival is necessary in order to ensure that 'full development', which is the ultimate goal of childhood. In other words, the drafters aspired to ensure that every child gets the opportunity to grow up to her or his fullest potential.

The discussion ended with the Working Group adopting the following text:

'1. States Parties recognize that every child has the inherent right to life.

2. States Parties shall ensure to the maximum extent possible the survival and development of the child. ${ }^{111}$

These words became the text of the Convention's Article 6.

\footnotetext{
${ }^{109}$ Ibid.

${ }^{110}$ Ibid.

${ }^{111}$ Ibid, 18.
} 
'Development' gained additional scarce attention in this round of discussion, while the Working Group debated the principle of the best interests of the child. 'Development' was mentioned at the margin of the debate on this principle, when the representative of Venezuela addressed the potential links between the principle of the best interests and children's development:

'although her delegation was not opposed to the phrase "best interests of the child" being included in the final text, she however wished to draw attention to the subjectivity of the term, especially of the Convention contained no prior stipulation that the "best interests of the child" were his all-round - in other words, physical, mental, spiritual, moral and social development. That would mean leaving the interpretation of the "best interests of the child" to the judgment of the person, institution or organization applying the rule. In the ensuing debate a number of delegations expressed satisfaction with the phrase and the representative of Venezuela therefore withdraws her suggestion'. ${ }^{112}$

Not only does this statement highlight the ambiguity and arbitrariness of the different terms that the drafters used throughout the years, it also draws attention to the subjective nature of the terms 'development', 'well-being', 'growth' and 'adulthood'. All these terms were used in order to describe a similar idea and to ensure the fulfilment of the same desire: to enable the child to transform into an adult and fulfil her or his inner potential. Furthermore, 'adulthood' as an ending point has various components in and of itself, which need to be protected during all the stages of childhood, and in relation to different aspects of the child's life. Ultimately, this ending point of childhood will only be achieved when the child becomes an adult.

\section{$\underline{\text { Discussion }}$}

The drafting process of the Convention informs us about the reasons for incorporating a wide protection for children's development into the Convention, the process that led to the creation of the rights to development and the drafters' perceptions about children's development and the right to development.

Despite the heterogeneous composition of the Open-Ended Working Group (geographically, institutionally etc), most, if not all, of the references to children's 'development' stemmed from a conviction on the conception of children as 'becomings' human beings. The drafters

${ }^{112}$ Ibid, 22. Emphasis added. 
shared the 'human becomings' conception of childhood, and created a Convention that ought to support and protect the main objective of this concept - children's growth. If, as I argue, this perception was the consensus among the drafters, then it is obvious why there was no pressing need to dwell on the meaning of 'development'. For this reason, not only did the Convention introduce a new right with the title 'the right to development', but it also embedded the protection for children's development in five other provisions. In that sense, as Heather Montgomery claims, the Conventionis designed to influence how children grow up, envisaging the child as 'an individual, autonomous being, an inheritor of liberal, humanist ideals of the Enlightenment'.113

The presumption that children's development is a term that does not invite interpretation is wrong. Its ambiguity led the drafters often to mix it with other terms such as children's 'wellbeing'. Likewise, the term 'well-being' is open to interpretation as well, and prima facia does not necessarily has the same meaning as 'children's development' has. ${ }^{114}$

There are four points that are worth discussing with respect to the drafting process and the meaning of the right to development. The first is the conclusions that can be drawn from the process of embedding the protection for 'development' in the Convention. The second is the meaning of Article 6 and the meaning of the rights to life and survival. The third is the meaning of Article 6 and the right to development. The fourth and final point is the differences between the Convention's right to development and the right to development in 'general' international law.

\section{Embedding the Protection of 'Children's Development' in the Convention}

The conception of children as 'human becomings' underpinned the drafting process of the Convention and led the drafters to introduce a new human right into the world of international human rights law: the right to development. This innovation continued the

\footnotetext{
113 Heather Montgomery, An Introduction to Childhood (Wiley-Blackwell, West Sussex UK 2009) 6.

114 Jane Aldgate, for example, suggests that Child's well-being is composed of ecological approach to child well-being, children's physical and psychological wellness, strengths and attachment. Jane Aldgate, 'Child Well-Being, Child Development and Family Life' in Colette McAuley and Wendy Rose (eds) Child Well-Being (Jessica Kingsley Publishers, London 2010) 21-38. For a more general discussion about the meaning of human well-being see James Griffin, Well-Being (Clarendon Press, Oxford 1986).
} 
evolutionary narrative of international children's rights law in protecting children's development that began in $1924 .^{115}$

The 'human becomings' conception led the drafters to assimilate the protection of eight components of 'children's development' into five different articles. The eight developmental components are: physical, mental, moral, social, cultural, spiritual, personality and talent. The Articles are Article 18(1), Article 23(3), Article 27(1), Article 29(1)(a) and Article 32(1) that refer to parental responsibility, protect children's right to health, the right to adequate standard of living, define the aims of education and protect the right to freedom from economic exploitation, respectively. ${ }^{116}$

The novelty in subjugating a human rights treaty to the developmentalist perception of childhood is also reflected in Article 5 of the Convention, which pins down the evolving capacities principle. Determining that the rights of children will be respected in a manner consistent with the evolving capacities of the child ${ }^{117}$ makes a specific perception of childhood the rule-of-thumb for the implementations of the Convention, and subjects the implementation of the Convention to children's 'development' stages. ${ }^{118}$

The centrality of the developmentalist concept stands in contrast to the lack of any substantial or thorough analysis of the meaning of children's development or the right to development, or any subsequent questions that follows. ${ }^{119}$ Analysing the drafting process, it is evident that

\footnotetext{
${ }^{115}$ On events and narratives in international law see Fleur Johns Pahuja, 'Introduction' in Fleur Johns, Richard Joyce and Sundhya Pahuja (eds) Events: The Force of International Law (Routledge, Oxford 2011) 1-17, 1-8.

${ }_{116}$ Article 18(1): 'States Parties shall use their best efforts to ensure recognition of the principle that both parents have common responsibilities for the upbringing and development of the child. Parents or, as the case may be, legal guardians, have the primary responsibility for the upbringing and development of the child. The best interests of the child will be their basic concern.'

Article 23(3): 'Recognizing the special needs of a disabled child, assistance extended in accordance with paragraph 2 of the present article shall be provided free of charge, whenever possible, taking into account the financial resources of the parents or others caring for the child, and shall be designed to ensure that the disabled child has effective access to and receives education, training, health care services, rehabilitation services, preparation for employment and recreation opportunities in a manner conducive to the child's achieving the fullest possible social integration and individual development, including his or her cultural and spiritual development.'

Article 27(1): 'States Parties recognize the right of every child to a standard of living adequate for the child's physical, mental, spiritual, moral and social development.'

Article 29(1): 'States Parties agree that the education of the child shall be directed to: (a) The development of the child's personality, talents and mental and physical abilities to their fullest potential.'

Article 32(1): 'States Parties recognize the right of the child to be protected from economic exploitation and from performing any work that is likely to be hazardous or to interfere with the child's education, or to be harmful to the child's health or physical, mental, spiritual, moral or social development.'

${ }^{117}$ Article 5.

118 Gerison Lansdown, The Evolving Capacities of the Child (Save the Children and UNICEF, Florence Italy 2005) 16.

${ }^{119}$ With the exception of the few comments made in the 1988 round of discussions.
} 
discussions concerning the micro level of what constitute a component of development and what factors might impact 'development' were held, while the macro level of the perception of childhood that this right was created in light of was rarely addressed.In most, if not in all, of the debates about the different articles that protect 'development', the drafters did not debate the conceptual issues that the right to development raises.

As the Working Group's Chairman explained (in an article published after the Convention was adopted), the Convention was designed in order to protect a universal course of growth:

'the physical and mental nature of the child is identical everywhere... the process of growth and adolescence takes a similar course in all children. Their physical and mental needs are also similar'. ${ }^{120}$

It is one thing to protect a (universal) model of child's development, and it is another to create a human right to development. The former does not necessarily leads to the latter.

\section{Understanding Article 6 and the Rights to Life and Survival}

Development became a human right as the drafting process was coming to an end. The right to development was introduced after a decade of discussions, at a time when different Articles already protected varieties of developmental domains. Moreover, the right to development was not introduced as an independent and separate right, but rather as part of a clause that also protected the right to life and the right to survival.

I suggest understanding these three rights as positioned on one continuum, with the right to life at one end, the right to survival in the middle and the right to development at the other end. The right to life is located at the negative end of the continuum. Traditional interpretations of the right to life proclaim that it imposes only negative duties on the state. It means that a state cannot unlawfully take away life, but it is also not required to take any positive obligations to ensure and protect life. For example, the right to life does not mean that the state has an obligation to provide food for a starving person, but it also cannot prevent one from eating. A more progressive interpretation tends to ease the dichotomy between the negative and positive obligations, especially when it comes to children. As Manfred Nowak asserts, the right to life under the Convention obligates States Parties to reduce mortality rate of babies, to ensure adequate nutrition for children, and act against

${ }^{120}$ Lopatka, supra n. 2. 
infanticide and reduce the number of homicides. ${ }^{121}$ But as we introduce more positive obligations into the meaning of the right to life, we move on the continuum towards the place where the right to survival is located, ${ }^{122}$ and the entitlements it mandates for children.

The right to survival, like the right to development, is another innovation of the Convention. According to the explanation given by the WHO during the drafting process, the right to survival means: 'growth monitoring, oral rehydration and disease control, breastfeeding, immunization, child spacing, food and female literacy'. ${ }^{123}$ Some of these goals overlap with the positive obligations that the right to life generates. Moreover, this interpretation does not sufficiently distinguish it from other rights of the child that the Convention protects, such as the right to health (Article 24), the right to an adequate standard of living (Article 27), and the right to education (Articles 28-29). Therefore, the question why did the drafters decide to enfold these issues together under the title of 'survival' and to designate a distinct obligation to fulfil them remains open.

A possible answer to this question is that context makes a difference and symbolism is important. Locating these obligations within the context of the life-survival-development continuum emphasises their importance to the child's future development. This context emphasises the pressing importance of protecting children's basic needs that are necessary for a healthy course of growth, and for providing equal opportunities to all children (the latter reason led the WHO to ask to include female literacy as part of this list of components).

This interpretation not only clarifies the importance of the right to survival, but also of the right to development, which is located at the positive end of the continuum. According to this line of analysis, the right to development is not about preventing a child from dying or providing the immediate needs required for her or his physical survival. The right to development addresses the long terms needs of the child. The right is a forward-looking right that focuses on the child's course of growth and future. It aims to provide for the child's maturation process and the future adult that the child will eventually become.

\footnotetext{
${ }^{121}$ Manfred Nowak, Article 6: The Right to Life, Survival and Development (Martinus Nijhoff Publishers, Leiden 2005) 18-35.

${ }^{122}$ See F. Menghistu, 'The Satisfaction of Survival Requirements' in B. G. Ramcharan (ed) The Right to Life in International Law (Martinus Nijhoff Publishers, Dordrecht 1985) 63-83.

${ }^{123}$ Supra n. 110.
} 


\section{Understanding Article 6 and the Right to Development}

The right to development should be understood as a positive right that aims to ensure the child's transformation into an adult. In light of the travaux préparatoires and the text of the Convention, I suggest that the right to development can be interpreted in five different ways. One inherent limitation of all of these suggestions is their usage of the same ambiguous terms that the drafters themselves used.

The first possible interpretation takes the right to development as a right that aims to protect the child's ability to reach the end point of the developmental process (i.e adulthood). Second, the right to development can be understood as a right that enables the process of growth itself. The third option combines the previous two together, suggesting that the right to development can be understood as a right that facilitates the course of growth and the desirable outcome of fulfilling the child's potential as an adult. The fourth option is to claim that the right to development lacks any substantial and distinct meaning. According to this interpretation, this right has no added value or distinct meaning over other rights in the Convention, such as the rights to life, survival, health, adequate standard of living or play and leisure.

The fifth option attempts to avoid these polarized views. This option substantiates Article 6 and delineates its distinct meaning, interpreting the right to development as the right of a child to have her or his materialistic and non-materialistic needs, which are required for a healthy process of growth, met. An obvious difficulty of this interpretation is that to some extents, it brings us back to square one. This suggestion derives from the above mentioned assumptions about children and development that underpinned the drafting process. Therefore, in order to substantiate it, first there is a need to unfold the meaning of 'children's development', what its necessary components are, and what 'healthy growth' is. The unfolding process requires making some normative decisions. It requires the acknowledgment that the alleged universality of 'development' is misleading, and there is more than one meaning to the psychological development of children, and that children's development is not only a concern of psychologists.

Having said that, this interpretation does provide a distinct meaning to Article 6 and justifies its existence. It protects more than a summary of the other developmental components that are protected by other Articles of the Convention. It requires taking the individual child's future seriously, mandates that all of the child's needs in course of childhood be met, in order 
to ensure the utilization of childhood in the form of adulthood. Ultimately, this interpretation is informed by 'human becomings' model of childhood, and rejecting this model of childhood pulls down its normative ground, leaves it without substantial meaning.

\section{The Convention and the Right to Development in 'General' International law}

The drafting process highlights the gap between the innovative nature of the Convention, as it comes to the right to development, and 'general' international law.As will be discussed in chapter five, the period when the Convention was drafted - from 1978 to 1989, was also the time when 'the right to development' was being intensively debated in international law. Moreover, just before India suggested including right to development in the Convention, the UN General Assembly adopted the 1986 Declaration on the Right to Development. According to the travaux préparatoires, neither this Declaration nor the meaning of the 'general' right to development was ever mentioned by the drafters. I doubt whether this omission was a result of lack of knowledge about these development in 'general' international law. A more plausible explanation is that the unquestioned belief in the "law of growth' of children ${ }^{124}$ and the aspiration to protect that growth led the drafters to ignore a new conception in international law, which had an identical title. Chapters five and six address this point in details.

\section{Conclusion}

The Convention's drafting process lasted eleven years, and the final text was a considerably different document compared to the original draft. While the original draft was areplica of the 1959 Declaration, the Convention is much broader in content and scope. The Convention protects more rights of children, introduces a more complex structure of responsibilities and duties divided between different duty bearers and creates a monitoring mechanism for its implementation. However, with respect to children's development, the final text did not change the underlying narrative of international children's rights law concerning the conception of childhood, and it upholds and embeds the 'human becomings' conception in the Convention. The Convention, in resemblance to the 1924 and 1959 Declarations, attempts to protect and actively promote children's development. The novelty of the Convention with this regard is not the protection it provides to children's development, but the creation of a

${ }^{124}$ See chapter one. 
right to development and the wide protection the Convention gives to a number of elements of the right, such as physical, emotional, spiritual and cultural development.

In light of the drafting process, this chapter suggested five different ways to interpret the meaning of the right to development. The most substantive interpretation suggests understanding the right to development as the right of a child to have her or his materialistic and non-materialistic needs, which are required for a healthy process of growth, met.

The Convention is not a Declaration, but rather a binding treaty that ought to be implemented by all of its parties. For this reason, the process of interpretation takes place in parallel to the implementation process. The next two chapters focus on this dual process by analysing the jurisprudence of the Convention's monitoring mechanism - the UN Committee on the Rights of the Child - on the right to development. 


\section{Chapter Three: The UN Committee on The Rights of the Child's}

\section{Jurisprudence on the Right to Development}

'The Committee expects States to interpret "development" in its broadest sense as a holistic concept, embracing the child's physical, mental, spiritual, moral, psychological and social development. Implementation measures should be aimed at achieving the optimal development for all children' (UN Committee on the Rights of the Child, General Comment Number 5) ${ }^{1}$

\section{$\underline{\text { Introduction }}$}

The next two chapters analyse the UN Committee on the Rights of the Child's jurisprudence on the child's right to development. These chapters aim to understand how the Committee conceptualises 'development' and,subsequently, how it interprets the child's right to development. This chapter methodically analyses all the Concluding Observations and General Comments issued by the Committee between the years 1993 and 2010. The findings and conclusions of this chapter form the basis of Chapter four. Based on interviews with members of the Committee, Chapter four seeks to understand how the Committee, as an institution, perceives the limitations and challenges of implementing the child's right to development.

This chapter consists of two parts. The first part describes the normative status of the Committee, the reporting procedures and methods of work. The second part critically analyses the Committee's jurisprudence with regard to children's development and the right to development. The main conclusion is that the Committee's jurisprudence mirrors the Convention's conception of children as 'human becomings'. Therefore, the Committee utilises non-legal bodies of knowledge, primarily developmental psychology, to scrutinize States Parties' implementation of the Convention, and to make recommendations concerning the care for children's development and their right to development. The Committee subjugates most of the Convention's rights to promote children's socio-psychological development, while ignoring the formulation of development as a human right in itself. The Committee fails to respect children's agency, and consequently fails to provide a distinct and concrete interpretation for the child's legal right to development.

\footnotetext{
${ }^{1}$ UNCRC, 'General Comment No. 5 - General Measures of Implementation of the Convention on the Rights of the Child' (27 November 2003) UN Docs CRC/GC/2003/5, paragraph 12.
} 
The Convention is the most ratified human rights treaty. As its monitoring body, the Committee therefore receives information from a wide range of sources and it is the institution most likely to have a comprehensive perspective about the state of the world's children (excluding the 400 million children living in the USA, Somalia and South Sudan, which have not ratified the Convention). ${ }^{2}$ This mass volume of information enables the Committee to have a broad perspective and understanding of the challenges and obstacles faced in implementing the Convention throughout the world, in different cultural, political, financial and social contexts. ${ }^{3}$ Over the last twenty years, the Committee has been systematically engaging with monitoring the Convention's protection for children's development and to a lesser extent, their right to development. Unfortunately, the Committee's work has not gained the academic attention it deserves. ${ }^{4}$

The Committee has defined Article 6 and the right to development as one of the Convention's four guiding principles, and asked States Parties to interpret the right as a broad and holistic concept that embraces 'the child's physical, mental, spiritual, moral, psychological and social development'. 5 Therefore, analysing the Committee's jurisprudence can have an important contribution to our understanding of the meaning of right to development under the Convention.

\footnotetext{
2 South Sudan was established as an independent state on July 2011. As of July 2012, it did not ratify any international human rights convention, including the Convention. See Human Rights Watch, South Sudan: Step Up Urgent Human Rights Reforms (5 July 2012).

${ }^{3}$ Gerison Lansdown, 'The Reporting Process Under the Convention on the Rights of the Child' in Philip Alston and James Crawford (eds) The Future of UN Human Rights Treaty Monitoring (Cambridge University Press, Cambridge 2000) 113-128. For a comparison between the monitoring processes of other UN treaty bodies see Christian Tomuschat, Human Rights - Between Idealism and Realism $\left(2^{\text {nd }}\right.$ edition, Oxford University Press, Oxford 2008) 175 - 191.

${ }^{4}$ But see the comprehensive work of Cynthia Price Cohen, Jurisprudence on the Rights of the Child, Volumes 14 (Transnational Publishers, New York 2005); Cynthia Price Cohen and Annemieke Wolthius, 'The Committee on the Rights of the Child: $8^{\text {th }}$ Session Reports of States Parties' (1995) 3 International Journal of Children's Rights 263; Annemieke Wolthuis and Denise Allen, 'Tenth Session of the Committee on the Rights of the Child: Consideration on State Party Reports' (1996) 4 International Journal of Children's Rights 69; Lisa Woll, 'Reporting to the UN Committee on the Rights of the Child: A Catalyst for Domestic Debate and Policy Change' (2000) 8 International Journal of Children's Rights 71; Lukas P. Scherer and Stuart N. Hart, 'Reporting to the UN Committee on the Rights of the Child - Analyses of the First 49 State Party Reports on the Education Articles of the Convention on the Rights of the Child and a Proposition for an Experimental Reporting System for Education' (1999) 7 International Journal of Children's Rights 349.

${ }^{5}$ UNCRC, 'General Comment number 5', supra n. 1.
} 


\section{The Committee's Normative Status and Methods of Work}

The Convention established the Committee on the Rights of the Child as its monitoring mechanism (Article 43). The Committee is composed of eighteen 'experts of high moral standing and recognised competence in the field covered by the Convention' (Article 43(2)). ${ }^{6}$ Its members are elected by States Parties for a term of four years, and can be reelected for another term of four years (Article 43(2)-43(6)). Since the establishment of the Committee in 1991 and until December 2011, sixty-one people had served as its members. ${ }^{7}$

According to the Convention, every State Party must report on measures it has 'adopted which give effect to the rights recognised herein and on the progress made on the enjoyment of these rights' (Article 44(1)). An initial implementation report should be submitted within two years of the Convention entering into force for the concerned State Party. Following this initial submission, periodic implementation reports should be submitted every five years, ${ }^{8}$ structured according to the Committee's reporting guidelines. ${ }^{9}$

As we saw in the previous chapter, in addition to Article 6's protection of the right to development, five other articles (Articles 18, 23, 2729 and 32) protect eight domains of children's development (physical, mental, moral, social, talents, cultural, spiritual and personal). Therefore, it is expected that each implementation report would refer to the measures taken with respect to the promotion of children's development and the right to development. ${ }^{10}$ In 2005, the Committee issued Revised Guidelines for reporting. The new guidelines seek to frame the implementation process as a 'holistic' process that conceptualises children's rights as 'indivisible and interrelated' rights ${ }^{11}$.The Revised Guidelines mention the right to development with respect to the implementation of Article 6 and the right to health (Article 24). However, where the Guidelines specify the type of data

\footnotetext{
${ }^{6}$ Initially, the Committee included ten members. Article 43 of the Convention was amended in 2002 and the number of members was increased to eighteen. UNGA Resolution 50/155 of 21 December 1995 (entered into force on 18 November 2002).

${ }^{7}$ The UN Committee on the Rights of the Child's website. http://www2.ohchr.org/english/bodies/crc/members.htm [last checked 20.10.2012]

${ }^{8}$ Article 44(1).

${ }^{9}$ UNCRC, 'General Guidelines Regarding Forms and Content of Initial Reports to be Submitted by States Parties Under Article 44(1)(a) of the Convention' (30 October 1991) UN Docs CRC/C/5 ['Initial Guidelines']; UNCRC, 'Overview of the Reporting Procedures' (24 October 1994) UN Docs CRC/C/33 ['General Guidelines']; UNCRC, 'General Guidelines Regarding the Forms and Content of Period Reports to be Submitted by States Parties Under Article 44(1)(b) of the Convention' (29 November 2005) CRC/C/58/Rev. 1 ['Revised Guidelines'].

${ }^{10}$ Initial Guidelines, ibid, paragraphs 13, 19; General Guidelines, ibid, paragraph 5; Revised Guidelines, ibid, Paragraphs 21, 30-31.

${ }^{11}$ Revised Guidelines, supra n. 9, paragraph 3.
} 
the Committee would like to receive with respect to Article 6, the requested information is only concerned with threats to children's right to life (number of deaths of those under 18 as a result of capital punishment, illness or traffic accidents). ${ }^{12}$ Thus, States Parties are not explicitly asked to provide data concerning the implementation of the right to development. Nonetheless, while this omission does not exempt States Parties from their obligation to protect this right, and to report about it, the guidelines create a situation where States Parties might be under the impression that they will not be held accountable for failing toprotect the right to development.

States Parties' submission of their implementation reports is the first step in the monitoring process. This step is then followed by the submission of UN agencies' reports and NGOs' shadow reports. On the bases of this information, the Committee holds a pre-sessional meeting where all the information is reviewed, ${ }^{13}$ and a list of follow-up questions ('List of Issues') is sent to the relevant State Party. ${ }^{14}$ Afterwards, representatives of each State Party appear before the Committee, and discuss their report with the Committee. This stage of the monitoring process ends with the publication of 'Concluding Observations'. ${ }^{15}$ The Concluding Observations include 'suggestions and recommendations' about the steps that need to be taken in order to advance the implementation of the Convention. ${ }^{16}$ The Concluding Observations do not mark the end of the monitoring process, as they are a stage in an ongoing dialogue between the Committee and each State Party. Each State Party is expected to follow the recommendations and to report back in five years time on the progress it has made.

In addition to the Concluding Observations, in 2001 the Committee began publishing 'General Comments'. The 'General Comments' address either specific issues or rights that the Committee considers to be important (for example, the aims of education or the right to participation) $)^{17}$, or, alternatively, focus on specific groups of children (such as indigenous

\footnotetext{
${ }^{12}$ Revised Guidelines, supra n. 9, paragraph 5.

13 Cynthia Price Cohenet al, 'Monitoring the United Nations Convention on the Rights of the Child: The Challenges of Information Management' (1996) 18 Human Rights Quarterly 439.

${ }^{14}$ General Guidelines, supra n. 9, paragraph 12.

15 Anne. F. Bayefsky, The UN Human Rights Treaty System - Universality at the Crossroads (Kluwer Law International, The Hague and London 2001).

${ }^{16}$ General Guidelines, supra n. 9, paragraphs 18-22.

${ }^{17}$ UNCRC, 'General Comment Number 1: The Aims of Education' (17 April 2001) UN Docs CRC/GC/2001/1; UNCRC, 'General Comment Number 12: The Right of the Child to Be Heard' (20 July 2009) UN Docs $\mathrm{CRC} / \mathrm{GC} / 2009 / 12$.
} 
children). ${ }^{18}$ Each of these stages needs tofunction well,in order to maximise the possibility for bringing about change inhuman rights protection at the national level. ${ }^{19}$

Neither the Concluding Observations nor the General Comments have a formal binding force. Nonetheless, their normative weight is not without significance, and they are an important source for interpreting and implementing the Convention. ${ }^{20}$ For the purposes of this research, the normative status of the Committee's jurisprudence is not a crucial point of focus. The Committee's jurisprudence is analysed because it sheds invaluable light on the theoretical and operational meanings of the right to development, while its force as a binding treaty is of less significance.

\section{Methodology}

The chapter analyses all 364 Concluding Observations published by the Committee since 1993, when it began reviewing States Parties' reports, up until 2010, as well as all 13 General Comments published until 2011. The analysis begins with the connection that the Committee has made between children's identity and their personal characteristics, such as gender, ethnicity and disability, discrimination and the right to development. It continues by discussing early childhood development, socio-economic conditions, and the connection between the rights to education and health and development. The analysis ends with the connection made between child labour and development.

The analysis is informed by three factors: the significance of protecting children's development in the Convention;the perception that the child's right to development should be interpreted in a broad and holistic manner; and the aim to locate children, their lives and rights in the centre of attention. Such an analysis is not free from problems, and two are worth emphasising. First, the analysis presents a summary of the Committee's jurisprudence, and, therefore, to some extent ignoreschanges in the Committee's jurisprudence over the years. Second, the analysis might not be sensitive enough to nuances of the Committee's

\footnotetext{
18 UNCRC, 'General Comment Number 11: Indigenous Children and their Rights Under the Convention' (12 February 2009) UN Docs CRC/C/GC/11.

19 John Morijn, 'Reforming United Nations Human Rights Treaty Monitoring Reform' (2011) 29 Netherlands International Law Review 295, 309.

${ }^{20}$ On the normative stand of the concluding observations see Michael O'Flaherty, 'The Concluding Observations of United Nations Human Rights Treaty Bodies' (2006) Human Rights Law Review 27, 31-36; See also Philip Alston, 'Conjuring up New Human Rights: A Proposal for Quality Control' (1984) 78 American Journal of International Law 607; Oona Hathaway, 'Do Human Rights Treaties Make a Difference?' (2002) 111 Yale Law Journal 1935.
} 
jurisprudence, especially with respect to the perception of children as a homogenous group with universal characteristics. In order to meet these concerns, where relevant, the analysis addresses changes and trends in the Committee's interpretation. But the problems posed by theassumptions about homogeneity and universality are more important. These postulates are part of the Convention biases and were not a creation of the Committee's work. ${ }^{21}$ Nevertheless, before criticising the Committee for neglecting social, historical, cultural, racial and political contexts and their potential influence on the interpretation of children's development and right to development, there is a need to present the Committee's jurisprudence as it is.

From Cradle to Adulthood - The Committee's Perspective on Children's Development and Right to Development

The Committee published its first Concluding Observations in 1993-1994. The right to development, or Article 6, was not mentioned, ${ }^{22}$ while the issue of children's development was referred to only rarely, mostly with regard to cases of births that were not supervised by qualified health workers, ${ }^{23}$ or with reference to the impact of insufficient nutritious food on children's survival and development. ${ }^{24}$ In the years that followed, the Committee's scope significantly expanded in two ways. First, many of the Convention's rights were linked to children's development. Second, the right to development began to gain attention and was mentioned as a distinct right of children.

\footnotetext{
${ }^{21}$ Kristina Anne Bentley, 'Can There Be Any Universal Children's Rights?' (2005) 9 International Journal of Children's Rights 107; Sonja Grover, 'A Response to K.A Bentley's 'Can There Be Any Universal Children's Rights?' (2007) 11 International Journal of Children's Rights 429; Adam Lopatka, 'The Rights of the Child are Universal: The Perspective of the UN Convention on the Rights of the Child' in Michael Freeman and Philip Veerman (eds) The Ideologies of Children's Rights (Martinus Nijhoff Publisher, Dordrecht 1992) 47-52; Roger Smith, A Universal Child? (Palgrave Macmillan, London 2009).

22 See, for example: UNCRC 'Concluding Observations: Sweden' (18 February 1993) UN Doc CRC/C/15/Add.2; UNCRC 'Concluding Observations: Viet Nam' (18 February 1993) UN Doc CRC/C/15/Add.3; UNCRC 'Concluding Observations: Russian Federation' (18 February 1993) UN Doc CRC/C/15/Add.4; UNCRC 'Concluding Observations: Egypt' (18 February 1993) UN Doc CRC/C/15/Add.5; UNCRC 'Concluding Observations: Sudan' (18 October 1993) UN Doc CRC/C/15/Add.10; UNCRC 'Concluding Observations: France' (25 April 1994) UN Doc CRC/C/15/Add. 20; UNCRC 'Concluding Observations: Honduras' (24 October 1994) UN Doc CRC/C/15/Add. 24; UNCRC 'Concluding Observations: Indonesia' (24 October 1994) UN Doc CRC/C/15/Add. 25.

${ }^{23}$ UNCRC 'Concluding Observations: Bolivia' (18 February 1993) UN Doc CRC/C/15/Add.1, paragraph 10.

${ }^{24}$ UNCRC 'Concluding Observations: Honduras' (1994), supra n. 22, paragraph 15.
} 


\section{$\underline{\text { Discrimination and Development }}$}

The right to non-discrimination is protected by Article 2 of the Convention, And like the right to development, it is also defined as one of the Convention's fourguiding principles. ${ }^{25}$ Neither the text of Article $2,{ }^{26}$ nor the drafting process of the Convention, ${ }^{27}$ suggests a connection between this right and children's development or their right to development. Nevertheless, since 2000 the Committee has made such a connection, concluding that a violation of the right to non-discrimination leads to the frustrating of children's development and right to development alike.

The Committee concluded that discrimination leads to incidents of 'harassments and hatred' 28 and 'racial hatred and xenophobia', ${ }^{29}$ and that discriminatory practices deny these children access to public services, especially housing, health services and education. ${ }^{30}$ On several occasions the Committee concluded that discriminatory practices have a negative effect on children's development, ${ }^{31}$ and violate their right to survival and development. ${ }^{32}$ These propositions were not followed with any explanation, and the Committee was satisfied with the conclusion that elimination of discrimination is, therefore, a vehicle for ensuring the elimination of obstacles that hinder the realisation of the right to development.

\footnotetext{
${ }^{25}$ UNCRC, General Comment No. 5, supra n. 1.

26 ' 1 . States Parties shall respect and ensure the rights set forth in the present Convention to each child within their jurisdiction without discrimination of any kind, irrespective of the child's or his or her parent's or legal guardian's race, colour, sex, language, religion, political or other opinion, national, ethnic or social origin, property, disability, birth or other status. 2. States Parties shall take all appropriate measures to ensure that the child is protected against all forms of discrimination or punishment on the basis of the status, activities, expressed opinions, or beliefs of the child's parents, legal guardians, or family members'.

${ }_{27}$ See chapter one; UNHCHR, Legislative History of the Convention on the Rights of the Child - Volume 1 (United Nations, New York and Geneva 2007) 314-334.

${ }^{28}$ UNCRC 'Concluding Observations: Croatia' (3 November 2004) UN Doc CRC/C/15/Add. 243, paragraph 21.

${ }^{29}$ UNCRC 'Concluding Observations: Germany' (26 February 2004) UN Doc CRC/C/15/Add. 226, paragraph 23.

${ }^{30}$ UNCRC 'Concluding Observations: Canada' (20 June 1995) UN Doc CRC/C/15/Add. 37, paragraph 17; UNCRC 'Concluding Observations: Senegal' (27 November 1995) UN Doc CRC/C/15/Add. 44, paragraph 12; UNCRC 'Concluding Observations: Czech Republic' (27 October 1997) UN Doc CRC/C/15/Add. 81, paragraph 15.

31 UNCRC 'Concluding Observations: Sierra Leone' (24 February 2000) UN Doc CRC/C/15/Add. 116, paragraph 40; UNCRC 'Concluding Observations: Croatia' (2004), supra n. 28, paragraph 21; UNCRC 'Concluding Observations: Germany' (2004), supra n. 29, paragraph 23; UNCRC 'Concluding Observations: France' (30 June 2004) UN Doc CRC/C/15/Add. 240, paragraph 16.

${ }^{32}$ UNCRC 'Concluding Observations: Burundi' (16 October 2000) UN Doc CRC/C/15/Add. 133, paragraph 77; UNCRC 'Concluding Observations: Cameroon' (2001), supra n. 34, paragraph 69; UNCRC 'Concluding Observations: Sudan' (9 October 2002) UN Doc CRC/C/15/Add. 190, paragraph 46; UNCRC 'Concluding Observations: Bangladesh' (1997), supra n. 34, paragraph 79; UNCRC 'Concluding Observations: India' (2004), supra n. 34, paragraph 81; UNCRC 'Concluding Observations: Myanmar' (2004), supra n. 38, paragraph 79; UNCRC 'Concluding Observations: Rwanda' (2004), supra n. 38, paragraph 75; UNCRC 'Concluding Observations: Yemen' (2005), supra n. 38, paragraph, 81.
} 
The Committee has expressed concernswith regard to discrimination against several specific groups of children, including girls, ${ }^{33}$ children of ethnic minorities, ${ }^{34}$ aboriginal children, ${ }^{35}$ indigenous children, ${ }^{36}$ children born out of wedlock, ${ }^{37}$ children form poorer income group, rural children, child refugees, working children, displaced children, ${ }^{38}$ children living or working on the street, child victims of sexual exploitation, ${ }^{39}$ and stateless children. ${ }^{40}$

The Committee dedicated special attention to discrimination against three groups of children: children suffering from gender-based discrimination, children with disabilities and indigenous children. With respect to gender-based discrimination, the Committee highlighteddifferent marriage ages for boys and girlsas a practice that has a negative impact on girls' 'health, education and social development'. ${ }^{41} \mathrm{~A}$ more comprehensive range of discriminatory practices against children with disabilities can be concluded from the Committee's work, and it includes, among others, lack of access to health services, mistreatment and inadequate diagnostic systems, ${ }^{42}$ inadequate schools $^{43}$ and education

\footnotetext{
${ }^{33}$ UNCRC 'Concluding Observations: Sri Lanka' (21 June 1995) UN Doc CRC/C/15/Add. 40, paragraph 12; UNCRC 'Concluding Observations: Senegal' (1995) supra n. 30, paragraph 12; UNCRC 'Concluding Observations: Angola' (11 October 2010) UN Doc CRC/C/CO/2-4, paragraphs 53-54.

${ }^{34}$ UNCRC 'Concluding Observations: United Kingdom' (15 February 1995) UN Doc CRC/C/15/Add. 34, paragraph 13; UNCRC 'Concluding Observations: Czech Republic' (1997), supra n. 30, paragraph 15; UNCRC 'Concluding Observations: Bangladesh' (18 June 1997) UN Doc CRC/15/C/Add. 74, paragraph 15; UNCRC 'Concluding Observations: Cameroon' (6 November 2001) UN Doc CRC/C/15/Add. 164, paragraph 69; UNCRC 'Concluding Observations: Bangladesh' (27 July 2003) UN Doc CRC/C/15/Add. 221, paragraph 79; UNCRC 'Concluding Observations: India' (26 February 2004) UN Doc CRC/C/15/Add. 228, paragraph 81; UNCRC 'Concluding Observations: Republic of Serbia' (20 June 2008) UN Doc CRC/C/SRB/CO/1, paragraph 75 .

${ }^{35}$ UNCRC 'Concluding Observations: Canada' (1995), supra n. 30, paragraph 17.

${ }^{36}$ UNCRC 'General Comment 11', supra n. 18; UNCRC 'Concluding Observations: Burundi' (1 October 2010) UN Doc CRC/C/BDI/CO/2, paragraphs 78-79; UNCRC 'Concluding Observations: Guatemala' (1 October 2010) UN Doc CRC/C/GTM/CO/3-4, paragraph 101.

37 UNCRC 'Concluding Observations: Sri Lanka' (1995), supra n. 33, paragraph 12; UNCRC 'Concluding Observations: Senegal' (1995), supra n. 33,paragraph 12; UNCRC 'Concluding Observations: Bangladesh' (1997), supra n. 34, paragraph 15.

${ }^{38}$ UNCRC 'Concluding Observations: Sri Lanka' (1995), supra n. 33, paragraph 12; UNCRC 'Concluding Observations: Myanmar' (30 June 2004) UN Doc CRC/C/15/Add. 237, paragraph 79; UNCRC 'Concluding Observations: India' (2004), supra n. 34, paragraph 81; UNCRC 'Concluding Observations: Rwanda' (1 July 2004) UN Doc CRC/C/15/Add. 234,paragraph 75; UNCRC 'Concluding Observations: Yemen' (21 September 2005) UN Doc CRC/C/15/Add. 267, paragraph 81.

${ }^{39}$ UNCRC 'Concluding Observations: Bangladesh' (1997), supra n. 34, paragraph 15.

${ }^{40}$ UNCRC 'Concluding Observations: Thailand' (17 March 2006) UN Doc CRC/C/THA/CO/2, paragraph 33; UNCRC 'Concluding Observations: Dominican Republic' (11 February 2008) UN Doc CRC/C/DOM/CO/2, paragraph 77 .

${ }^{41}$ For example, see UNCRC 'Concluding Observations: Nicaragua' (20 June 1995) UN Doc CRC/C/15/Add. 36, paragraph 13; UNCRC 'Concluding Observations: India' (2004), supra n. 34, paragraph 60.

${ }^{42}$ UNCRC ‘Concluding Observations: Russian Federation' (10 November 1999) UN Doc CRC/C/15/Add. 110, paragraph 40

${ }^{43}$ UNCRC 'Concluding Observations: Estonia' (17 March 2003) UN Doc CRC/C/15/Add. 196, paragraph 39.
} 
programmes, ${ }^{44}$ and other facilities and programmes that meet their needs. ${ }^{45}$ These discriminatory practices were often mentioned as having a negative effect on their 'development' in general, ${ }^{46}$ and their cultural development in particular. ${ }^{47}$ The Committee further made a connection between the care for the development of children with disabilities and their ability to maximize their potential, ${ }^{48}$ their inclusion in society, ${ }^{49}$ and their 'enjoyment of a full and decent life and participation in the community' ${ }^{50}$ The care for these children's future development exceeds the usual ambiguous care the Committee expresses for 'development', and substantiates it little more. This position links 'development' to the fulfilment of the human potential of these children, which in return is influenced by how they are integrated in society. It therefore seems, according to the Committee, marginalisation interferes with the ability of children to develop.

General Comment number $9,{ }^{51}$ which is dedicated to the rights of children with disabilities, includes some further statements about this issue. In this General Comment, the Committee emphasised that social discrimination and stigmatization leads to the 'marginalisation and exclusion' of children with disabilities, which 'may even threaten their survival and development if it goes as far as physical or mental violence against [them] ${ }^{52}$ Later on in the

\footnotetext{
${ }^{44}$ UNCRC 'Concluding Observations: Sudan' (2002), supra n. 32, paragraph 46; UNCRC 'Concluding Observations: Estonia' (2003), Ibid; UNCRC 'Concluding Observations: India' (2004), supra n. 34, paragraph 81; UNCRC 'Concluding Observations: Republic on Congo' (20 October 2006) UN Doc CRC/C/COG/CO/1, paragraph 56; UNCRC 'Concluding Observations: Latvia' (28 June 2006) UN Doc CRC/C/LTC/CO/2, paragraph 40; UNCRC 'Concluding Observations: Uruguay' (5 July 2007) UN Doc CRC/C/URY/CO/2, paragraph 48; UNCRC 'Concluding Observations: Republic of Serbia' (2008), supra n. 34, paragraph 75. A recent study has found that in schools, children with disabilities are more likely to be victims of violence than other pupils who are not disabled. Lisa Jones et al, 'Prevalence and Risk of Violence Against Children With Disabilities: A Systematic Review and Meta-analysis of Observational Studies' 2012 Lancet (12 July 2012 online edition).

${ }^{45}$ UNCRC 'Concluding Observations: Djibouti' (28 June 2000) UN Doc CRC/C/15/Add. 131, paragraph 39; UNCRC 'Concluding Observations: Comoros' (23 October 2000) UN Doc CRC/C/15/Add. 141, paragraph 37.

${ }^{46}$ UNCRC 'Concluding Observations: New Zealand' (24 January 1997) UN Doc CRC/C/15/Add. 71, paragraph 5; UNCRC 'Concluding Observations: Russian Federation' (1999), supra n. 42, paragraph 40; UNCRC 'Concluding Observations: Djibouti' (2000), ibid, paragraph 39; UNCRC 'Concluding Observations: Comoros' (2000), ibid, paragraph 37; UNCRC 'Concluding Observations: Sudan' (2002), supra n. 32, paragraph 46; UNCRC 'Concluding Observations: Estonia' (2003), supra n. 43, paragraph 39; UNCRC 'Concluding Observations: Congo' (2006), supra n. 44, paragraph 56; UNCRC 'Concluding Observations: Latvia' (2006), supra n. 44, paragraph 40.

${ }^{47}$ UNCRC 'Concluding Observations: Uruguay' (2007), supra n. 44, paragraph 48.

${ }^{48}$ UNCRC 'Concluding Observations: New Zealand' (1997), supra n. 46, paragraph 5.

49 UNCRC 'Concluding Observations: Russian Federation' (1999), supra n. 42, paragraph 40; UNCRC 'Concluding Observations: Djibouti' (2000), supra n. 45, paragraph 39; UNCRC 'Concluding Observations: Comoros' (2000), supra n. 45, paragraph 37; UNCRC 'Concluding Observations: Estonia' (2003), supra n. 43, paragraph 39; UNCRC 'Concluding Observations: Latvia' (2006), supra n. 44, paragraph 40.

${ }^{50}$ UNCRC 'Concluding Observations: Congo' (2006), supra n. 44, paragraph 56.

${ }^{51}$ UNCRC 'General Comment Number 9 - The Rights of Children with Disabilities' (27 February 2007) UN Doc $\mathrm{CRC} / \mathrm{C} / \mathrm{GC} / 9$.

${ }^{52}$ Ibid, paragraph 8 .
} 
General Comment, the Committee broadened its claim, saying that the 'spiritual, emotional and cultural development and wellbeing of children with disabilities are very often overlooked', ${ }^{3}$ and therefore suggested establishing 'programmes and activities designed for the child's cultural development and spiritual wellbeing' ${ }^{54}$ However, only at the end of the General Comment did the Committee mention the right to development, stating that not only discrimination against children with disabilities poses risk to their development, but can also result in the violation of numerous rights, including the right to development. ${ }^{55}$ Nonetheless, no distinction between the child's 'development' and the child's 'right to development' was drawn, and no explanations for any of these conclusions were given.

The third group of children is children belonging to indigenous populations. The most comprehensive discussion about the rights of this group of children can be found in General Comment number $11 .^{56}$ At the outset, the General Comment repeated the same comments concerning discrimination and its impact on children's development, which had previously been made with respect to other marginalised groups of children, ${ }^{57}$ but then it added some new comments. The novelty of this General Comment is the explicit references to the right to development that it makes, as opposed to merely referencing the broad, and vague, 'development' of the child, as the Committee usually does. For example, the Committee expressed its concern that due to the particular vulnerability of indigenous children and the high level of poverty among them, discrimination could not only impact their 'survival and development', but also their right to an adequate standard of living. ${ }^{58}$ Based on Article 30 of the Convention, which protects the identity rights of children of indigenous people and children belong to linguistic, religious or cultural minorities, the Committee placed great importance on protecting traditions and cultures, 'particularly with reference to the protection and harmonious development of the child' ${ }^{59}$ The Committee further added that in cases where the child's community 'retain[s] a traditional lifestyle, the use of traditional land is of significant importance to their development and enjoyment of culture' ${ }^{60}$ Therefore, States

\footnotetext{
${ }^{53}$ Ibid, paragraph 33 .

${ }^{54}$ Ibid, paragraph 33. See also 2010 UNCRC 'Concluding Observations: Belgium' (18 June 2010) UN Doc $\mathrm{CRC} / \mathrm{C} / \mathrm{BEL} / \mathrm{CO} / 3-4$, paragraph 45.

${ }^{55}$ General Comment 9, supra n. 51, paragraph 32.

${ }^{56}$ General Comment 11, supra n. 18.

${ }^{57}$ Ibid, paragraph 22.

${ }^{58}$ Ibid, paragraph 34.

${ }^{59}$ Ibid, paragraph 35.

${ }^{60}$ Ibid.
} 
Parties should guarantee that their policies concerning culture and land ensure 'children's right to life, survival and development to the maximum extent possible' ${ }^{61}$

It can be therefore concluded that according to the Committee, protecting the right to nondiscrimination is a precondition for realising children's development and right to development. However, the Committee does not sufficiently distinguish, if at all, between the promotion of children's development and between the promotion of the right to development.

\section{Birth Registration}

Article 7 of the Convention establishes the right of every child to acquire a nationality, to be registered immediately after birth, and the right to a name. While Article 7 makes no connection between these rights and the child's development or the right to development, the Committee connects the two, determining that having a birth certificate is another precondition for the realisation of the right to development, for two reasons.

First, lack of national birth registration has a negative impact on a child's sense of personal identity. Second, in similarity to the argument put forward with respect to the right to nondiscrimination, without being registered at birth, children may be denied 'entitlements to basic health, education and social welfare'. Therefore, as 'a first step in ensuring the rights to survival, development and access to quality services for all children (Art. 6), the Committee recommends that States parties take all necessary measures to ensure that all children are registered at birth' ${ }^{62}$

The ways in which the Committee understands what 'child's development' means can be gleaned from the connection it makes between the child's knowledge about her origins and child's development, and between the important of access to education and health and development. Without explicitly mentioning it, the Committee is concerned with the child sense of self, and holds the view that education and health are important for healthy development and the development of the child's talents and knowledge. But the Committee does not delineate whether, if at all, it distinguishes between the support for the child's development and the realisation of the child's right to development.

\footnotetext{
${ }^{61}$ Ibid

${ }^{62}$ Ibid.
} 


\section{The Child's Family}

The Convention puts forward the assumption that a child should grow up in a household headed by two parents, ${ }^{63}$ and determines that both parents should share the responsibility for their child's development. ${ }^{64}$ The discussions about parental responsibilities focus on two issues that the Committee considers most relevant for children's development: family structure and child rearing.

Family structure. The Committee has emphasised time and time again the influence that family structures have on children's development (while ignoring the right to development). Constant references were made to the negative impact that 'single parenthood'65 and 'early parenthood' have on children's development. ${ }^{66}$ However, no specific age that qualifies to be 'too young' is mentioned.

The Committee also expressed concern with polygamy, asking States Parties to 'undertake an in-depth and comprehensive study on impact of polygamy in order to find out whether polygamy has negative consequences on the upbringing and development of children' ${ }^{67}$ No other types of family structures, such as children of same sex couples, children whose separated parents have a new partner and spend their time in two households, adoption or children born as a result of using reproductive technologies are mentioned by the Committee. The Committee also ignores the relationship between children's development and children who are being brought up in non-Western family structures. For example, children who are raised by members of their extended families, and not by their parents. This omission is

\footnotetext{
63 Articles 3, 5, 7, 9, 10, 14, 19, 21, 22, 23, 27, 29 and 40. See, for example, Article 9(3) 'States Parties shall respect the right of the child who is separated from one or both parents to maintain personal relations and direct contact with both parents...'; Article 18 'States Parties shall use their best efforts to ensure recognition of the principle that both parents...'

64 Article 18.

${ }^{65}$ UNCRC 'Concluding Observations: Spain' (24 October 1994) UN Doc CRC/C/15/Add. 28, paragraph 21; UNCRC 'Concluding Observations: Barbados' (24 August 1999) UN Doc CRC/C/15/Add. 103, paragraph 20; see also UNCRC 'Concluding Observations: Tajikistan' (5 February 2010) UN Doc CRC/C/TJK/CO/2, paragraph 43 .

66 UNCRC 'Concluding Observations: Spain' (1994), ibid; UNCRC 'Concluding Observations: Barbados' (1999), Ibid; UNCRC 'Concluding Observations: Tajikistan' (2010), ibid.

${ }^{67}$ UNCRC 'Concluding Observations: Djibouti' (7 October 2008) UN Doc CRC/C/DJI/CO/2, paragraph 40.
} 
rather surprising, taking the Committee's own terms, and the determination about the likelihood that these kinds of family structures affect children's development.

Moreover, if the parent's age is a relevant factor with regard to the child's development, as mentioned earlier, why does the Committee not mentioning 'late parenthood' or a 'maximum' age to become a parent? One possible explanation is that 'early parenthood' is a practice that was, and still is, common in the non-Western world and therefore can easily be criticized. While on the other hand, changes in the labour market and increasing use of fertility treatment by middle class people in the Western world, have created a situation where more people become parents in later stages of their life. This 'late parenting' is socially acceptable, and, therefore, the Committee did not ask any questions with regard to the impact of this phenomenon on children's development. Therefore, the Committee'scultural biases leads to a situation where the Committee fails to equally implement its conception of children's development on all children, including those who live in what the Committee itself conceives as less common family structures.

Child rearing. The Committee concludes that the child's mother should be the caregiver and the child's father should be the breadwinner. Fathers, in general, should also be 'involved enough' in the upbringing of the child. ${ }^{68}$ If the mother works outside the home and the child is left at a nursery, States Parties should provide sufficient resources for child care, or otherwise the child's 'full physical, mental and intellectual development' may not be sufficiently supported. ${ }^{69}$ While the Committee urges States Parties to be active in ensuring that both parents follow their obligations towards their children, it is also concerned with States Parties interference with the family unit, stating that it is 'excessive degree of State involvement in children to the detriment of the parental involvement, hindering psychosocial and cognitive development of the child ${ }^{70}$ The Committee is not only alarmed bythe intrusion of the family "privacy", but also, on the other hand, with the 'breakdown of families', since these situations 'can have a negative impact on their [children's] harmonious development'. ${ }^{71}$

\footnotetext{
${ }^{68}$ UNCRC 'Concluding Observations: Barbados' (1999), supra n. 65; UNCRC 'Concluding Observations: Zambia' (2 July 2003) UN Doc CRC/C/15/Add. 206, paragraph 35; UNCRC 'Concluding Observations: Nigeria' (13 April 2005) UN Doc CRC/C/15/Add. 257, paragraph 40.

${ }^{69}$ UNCRC 'Concluding Observations: Nigeria' (2005), ibid; See also UNCRC 'Concluding Observations: Jamaica’ (15 February 1995) UN Doc CRC/C/15/Add. 32, paragraph 24.

70 UNCRC 'Concluding Observations: Democratic People's Republic of Korea' (1 July 2004) UN Doc CRC/C/15/Add. 239, paragraph 38.

${ }^{71}$ UNCRC ‘Concluding Observations: Paraguay' (6 November 2001) UN Doc CRC/C/15/Add. 166, paragraph 33.
} 
Therefore, in cases of separation, States Parties need to assist 'both parents in the performance of their child-rearing responsibilities'. ${ }^{72}$

Child rearing includes a wide-range of activities, but with regard to children's development, the Committeefocuses on one aspect: violence against children. While the text of the Convention is silent on the matter (Article 19), the Committee holds the position that one of the consequences of violence is a negative effect on children's development. ${ }^{73}$

Corporal punishment is only one form of domestic abuse, which can be inflicted by parents, siblings or members of the extended family. Regardless of any classification of this act, as a form of discipline, part of cultural or religious practice or an abusive act, from the early days of its work, the Committee held the view that corporal punishment is prohibited under Article 19 , violates children's right to dignity ${ }^{74}$ and stands against numerous other rights of children that are covered by the Convention's Articles 3, 5, 12, 28, 37, 39 and $6 .{ }^{75}$ In light of this strong position, theCommitteecalled States Parties to 'effectively prevent and combat forms of corporal punishment and ill treatment of children' within the family, as well as in school or other institutions where children may be placed. ${ }^{76}$ Due to the wide dispersionof corporal punishment, and the fact that it is, to varying extents, legal in most Member States (as of October 2012, only 33 countries have prohibited corporal punishment), the Committee dedicated two General Comments to this issue: General Comment No. 8 (2008) ${ }^{77}$ and General Comment No. 13 (2011). ${ }^{78}$

72 UNCRC 'Concluding Observations: Spain' (1994), supra n. 65, paragraph 21; UNCRC 'Concluding Observations: Czech Republic' (18 March 2003) UN Doc CRC/C/15/Add. 201, paragraph 42; UNCRC 'Concluding Observations: Equatorial Guinea' (3 November 2004) UN Doc CRC/C/15/Add. 245, paragraph 41; UNCRC 'Concluding Observations: Paraguay’ (10 February 2010) UN Doc CRC/C/PRY/CO/3, paragraph 30.

${ }^{73}$ UNCRC 'Concluding Observations: Peru' (22 February 2000) UN Doc CRC/C/15/Add. 120, paragraph 10; UNCRC 'Concluding Observations: Russian Federation' (23 November 2005) UN Doc CRC/C/RUS/CO/3, paragraph 39.

${ }_{74}^{74}$ UNCRC ‘Concluding Observations: Yemen' (10 May 1999) UN Doc CRC/C/15/Add. 102, paragraph 21.

${ }^{75}$ UNCRC 'General Comment 8 - The Rights of the Child for Protection From Corporal Punishment and other Cruel or Degrading Forms of Punishment' (2 March 2007) UN Doc CRC/GC/8; UNCRC 'General Comment 13

- The Right of the Child to Freedom from all Forms of Violence' (18 April 2011) UN Doc CRC/C/GC/13; UNCRC 'Concluding Observations: Australia' (10 October 1997) UN Doc CRC/C/15/Add. 79, paragraph 15; UNCRC 'Concluding Observations: Libya Arab Jamahiriya' (4 February 1998) UN Doc CRC/C/15/Add. 84, paragraph 14; UNCRC 'Concluding Observations: Fiji' (24 June 1998) UN Doc CRC/C/15/Add. 89, paragraph 16; UNCRC 'Concluding Observations: Japan' (5 June 1998) UN Doc CRC/C/15/Add. 90, paragraph 45; UNCRC 'Concluding Observations: Luxemburg' (24 June 1998) UN Doc CRC/C/15/Add. 92, paragraph 31; UNCRC 'Concluding Observations: Yemen', ibid; UNCRC 'Concluding Observations: Barbados', supra n. 65, paragraph 22; UNCRC 'Concluding Observations: New Zealand' (27 July 2003) UN Doc CRC/C/15/Add. 216, paragraph 30; UNCRC 'Concluding Observations: Czech Republic' (2003), supra n. 72, paragraphs 39-41; UNCRC 'Concluding Observations: Austria' (January 2005) UN Doc CRC/C/15/Add. 251, paragraph 40.

76 UNCRC 'Concluding Observations: Canada' (1995), supra n. 35, paragraph, 14.

${ }^{77}$ UNCRC 'General Comment 8', supra n. 75.

${ }^{78}$ UNCRC 'General Comment 13', supra n. 75, paragraph 15. 
The Committee stated that corporal punishment hinders children's 'optimal development', ${ }^{79}$ and delineated the 'developmental and behavioural consequences' of violence against children:

'School non-attendance and aggressive, antisocial, self-destructive and interpersonal destructive behaviours. [They] can lead, inter alia, to deterioration of relationships, exclusion from school and conflict with the law. There is also evidence that exposure to violence increases a child's risk of further victimization and an accumulation of violent experiences, including later intimate partner violence'. ${ }^{80}$

The Committee's position is simple: States Parties need to outlaw these practices. States Parties should take legislative and other measures, such as awareness raising campaigns, to combatsexual and emotional abuse. ${ }^{81}$ These educational campaigns should be 'aimed at promoting positive, non violent forms of discipline and respect for children's rights to human dignity and physical integrity', ${ }^{82}$ and the 'negative effects of corporal punishment on the development of children' ${ }^{83}$ In order to care for the 'physical and psychological recovery and social integration ${ }^{84}$ of children who suffered from abuse, States Parties have a duty to establish and to sustain support services for them.

Another form of violence that the Committee extensively referred to are harmful traditional practices. Article 24(3) of the Convention requires States Parties to 'take all effective and appropriate measures with a view to abolishing traditional practices prejudicial to the health of children'. However, due to a lack of consensus among the drafters, the Convention does not specify what these practices are. ${ }^{85}$ The Convention does not link these practices to children's development, but the Committee has made such a link, while gradually developing a definite list of these practices.

\footnotetext{
${ }^{79}$ Ibid.

${ }^{80}$ Ibid.

${ }^{81}$ UNCRC 'Concluding Observations: Vanuatu' (10 November 1999) UN Doc CRC/C/15/Add. 111, paragraph 17; UNCRC 'Concluding Observations: Peru' (2000), supra n. 73, paragraph 22.

${ }^{82}$ UNCRC 'Concluding Observations: New Zealand' (2003), supra n. 75, paragraph 30.

${ }^{83}$ UNCRC 'Concluding Observations: Australia' (2005, supra n. 75, paragraph 40.

${ }^{84}$ UNCRC 'Concluding Observations: Vanuatu' (1999), ibid.

${ }^{85}$ UNHCHR, Legislative History of the Convention on the Rights of the Child - Volume 1, supra n. 27, 580-603. See also Sonia Harris-Short, 'International Human Rights Law: Imperialist, Inept and Ineffective? Cultural Relativism and the UN Convention on the Rights of the Child' (2003) 25 Human Rights Quarterly 130, 136146.
} 
In the early years of its work, the Committee addressed 'traditional cultural attitudes towards children... [which] may contribute to hampering the implementation of the Convention ${ }^{86}$ in general terms and without defining what these attitudes are or what their implications might be. Soon after, the Committee began to specify what these practices are. Today, the list includes dowry ${ }^{87}$, early marriage ${ }^{88}$ forced marriage, ${ }^{89}$ female genital mutilation (FGM), ${ }^{90}$ corporal punishment, amputation, scarring, burning and branding, infanticide, violent and degrading initiation rites, force feeding of girls, fattening, virginity testing, ${ }^{91}$ 'honour' crimes, accusation of witchcraft and uvulectomy and teeth extraction. ${ }^{92}$

The Committee concludes that these practices are harmful not only to children's health, ${ }^{93}$ as the Convention states, but also to children's lives, ${ }^{94}$ survival and development, ${ }^{95}$ nutrition ${ }^{96}$

${ }^{86}$ UNCRC 'Concluding Observations: Nigeria' (30 October 1996) UN Doc CRC/C/15/Add. 61, paragraph 9. But see UNCRC 'Concluding Observations: Qatar' (14 October 2009) UN Doc CRC/C/QAT/CO/2, paragraph 55, where the Committee mentions early marriage 'and other traditional practices harmful to the health, wellbeing and development of children'.

${ }^{87}$ UNCRC 'Concluding Observations: Bangladesh' (1997), supra n. 34, paragraph 15

${ }^{88}$ UNCRC 'Concluding Observations: Cyprus' (7 June 1996) UN Doc CRC/C/15/Add. 59, paragraph 16; UNCRC 'Concluding Observations: Bangladesh' (1997), supra n. 34, paragraph 15; UNCRC 'Concluding Observations: Republic of Chad' (12 February 2009) UN Doc CRC/C/TCD/CO/2, paragraph 62; UNCRC 'Concluding Observations: Qatar' (2009), supra n. 86, paragraph 55; UNCRC 'Concluding Observations: Nigeria' (11 June 2010) UN Doc CRC/C/NGA/CO/3-4, paragraph 65.

${ }^{89}$ UNCRC 'Concluding Observations: Chad' (2009), ibid, paragraph 62.

${ }^{90}$ UNCRC 'Concluding Observations: Uganda' (23 November 2005) UN Doc CRC/C/UGA/CO/2, paragraph 56; UNCRC 'Concluding Observations: Benin' (20 October 2006) UN Doc CRC/C/BEN/CO/2, paragraph 54; UNCRC 'Concluding Observations: United Republic of Tanzania' (21 June 2006) UN Doc CRC/C/TZA/CO/2, paragraph 50; UNCRC 'Concluding Observations: Kenya' (19 June 2007) UN Doc CRC/C/KEN/CO/2, paragraph 53; 2010 Nigeria, supra n. 88, paragraph 66. Previously, the Committee used to refer to FGM as a harmful practice, but without determining that it impacts children's development. See UNCRC 'Concluding Observations: Nigeria' (1996), supra n. 86 and UNCRC 'Concluding Observations: Djibouti' (2000), supra n. 45.

${ }^{91}$ UNCRC 'Concluding Observations: Benin' (24 August 1999) UN Doc CRC/C/15/Add. 106, paragraph 16; UNCRC 'Concluding Observations: Russian Federation' (2005) Russia, supra n. 73, paragraph 28; UNCRC 'Concluding Observations: Benin' (2006), ibid, paragraph 31; UNCRC 'Concluding Observations: Maldives' (13 July 2007) UN Doc CRC/C/MDV/CO/3, paragraph 42.

${ }^{92}$ UNCRC 'General Comment 13', supra n. 75, paragraph 29.

${ }^{93}$ UNCRC 'Concluding Observations: Bangladesh', supra n. 34, paragraph 15; UNCRC 'Concluding Observations: United Republic of Tanzania' (9 July 2001) UN Doc CRC/C/15/Add. 156, paragraph 51; UNCRC 'Concluding Observations: Kenya' (7 November 2001) UN Doc CRC/C/15/Add. 160, paragraph 48; UNCRC 'Concluding Observations: India', supra n. 34, paragraph 59; UNCRC 'Concluding Observations: Uganda' (2005), supra n. 90, paragraph 56; UNCRC 'Concluding Observations: Benin' (2006), supra n. 90, paragraph 54; UNCRC 'Concluding Observations: United Republic of Tanzania' (2006), supra n. 90, paragraph 51; UNCRC 'Concluding Observations: Kenya' (2007),supra n. 90, paragraph 54; UNCRC 'Concluding Observations: Chad' (2009), supra n. 88, paragraph 62; UNCRC 'Concluding Observations: Qatar' (2009), supra n. 86, paragraph 55.

${ }^{94}$ UNCRC 'Concluding Observations: Maldives' (2007), supra n. 91, paragraph 42.

95 UNCRC 'Concluding Observations: Cyprus' (1996), supra n. 88, paragraph 16; UNCRC 'Concluding Observations: Central African Republic' (18 October 2000) UN Doc CRC/C/15/Add. 138, paragraph 33; UNCRC 'Concluding Observations: United Republic of Tanzania' (2001), supra n. 93, paragraph 51; UNCRC 'Concluding Observations: Kenya' (2001), supra n. 93, paragraph 48; UNCRC 'Concluding Observations: India' (2004), supra n. 34, paragraph 59; UNCRC 'Concluding Observations: Uganda' (2005), supra n. 90, paragraph 56; UNCRC 'Concluding Observations: Benin' (2006), supra n. 90, paragraph 54; UNCRC 
and education. ${ }^{97}$ Early marriage and FGM were explicitly defined as being 'harmful to physical and psychological well-being of children'. ${ }^{98}$ Although girls are more likely to be subject to these practices, ${ }^{99}$ the Committee nevertheless emphasises that on the whole, these practices impact on 'boys as well as girls'. ${ }^{100}$ Therefore, States Parties need 'to combat' these practices 'effectively' 101 , including taking 'legislative and awareness raising measures to prohibit and eradicate ${ }^{, 102}$ these practices. These educational campaigns should target 'the extended family and the traditional and religious leaders'. ${ }^{103}$ Recently, States Parties were also asked to empower girls so they can decide 'on their own body and their plans for education and their future and also to make the public aware of girls' right to be respected, protected and supported in their personal development' ${ }^{104}$

According to the Committee, violence against children violates a number of human rights, is harmful to children's psychological development and their well-being, poses a risk to their mental development and might even cause permanent mental impairments.

Though the Committee does not do so explicitly, it is obvious that the Committee utilizes developmental psychology when it comments about the influence of family structures and child rearing practices on children's development. While the Committee's choice to adopt a certain concept of developmental psychology can be criticized, a larger problem liesin the way the Committee implements its conceptual framework. The Committee's view of the role of families and parents in caring for children's development is relatively clear. However,

'Concluding Observations: Tanzania' (2006), supra n. 90, paragraph 51; UNCRC 'Concluding Observations: Kenya' (2007) supra n. 90, paragraph 54; UNCRC 'Concluding Observations: Chad' (2009), supra n. 88, paragraph 62; UNCRC 'Concluding Observations: Qatar' (2009), supra n. 86, paragraph 55.

96 UNCRC 'Concluding Observations: Bangladesh' (2003), supra n. 34, paragraph 15.

${ }^{97}$ Ibid.

${ }^{98}$ UNCRC 'Concluding Observations: Nepal' (21 September 2005) UN Doc CRC/C/15/Add. 261, paragraph 68. But see General Comment 3, where the emphasis is on the damage it causes for girls. UNCRC 'General Comment Number 3 - HIV/AIDS and the Rights of the Child' (17 March 2003) UN Doc CRC/GC/3/2003, paragraph 11. UNCRC 'Concluding Observations: Qatar' (2009), supra n. 86, paragraph 55.

${ }^{99}$ UNCRC 'Concluding Observations: Uganda' (2005), supra n. 90, paragraph 56; UNCRC 'Concluding Observations: Benin' (2006), supra n. 90, paragraph 54; UNCRC 'Concluding Observations: Tanzania' (2006), supra n. 90, paragraph 51; UNCRC 'Concluding Observations: Kenya' (2007), supra n. 90, paragraph 54; UNCRC 'Concluding Observations: Chad' (2009), supra n. 88, paragraph 62; UNCRC 'Concluding Observations: Qatar' (2009), supra n. 86, 55.

${ }^{100}$ UNCRC 'Concluding Observations: Kenya' (2001), supra n. 93, paragraph 48. UNCRC 'Concluding Observations: India' (2004), supra n. 34, paragraph 59.

${ }^{101}$ UNCRC 'Concluding Observations: Turkey’ (9 July 2001) UN Doc CRC/C/15/Add. 151, paragraph 32.

${ }^{102}$ UNCRC 'Concluding Observations: Kenya' (2001), supra n. 93, paragraph 48. UNCRC 'Concluding Observations: India' (2004), supra n. 34, paragraph 59; UNCRC 'Concluding Observations: Uganda' (2005), supra n. 90, paragraph 56; UNCRC 'Concluding Observations: Benin' (2006), supra n. 90, paragraph 54; UNCRC 'Concluding Observations: Chad' (2009), supra n. 88, paragraph 62.

${ }^{103}$ UNCRC 'Concluding Observations: Uganda' (2005), supra n. 90, paragraph 56.

${ }^{104}$ UNCRC 'Concluding Observations: Angola' (2010), supra n. 33, paragraph 54. 
their role vis-à-vis the right to development of their children has, as this research shows, been largely ignored.

\section{Deprivation of Family Environment}

Over the years, the Committee referred to several groups of children who are deprived of a family environment, thus further emphasizing the importance of the family environment to children's development. These groups of children include children who are abandoned by their families, children whose parents (one or both) are imprisoned or live in other state institutions (for example, hospitals or rehab centres), children who are themselves imprisoned or admitted to a hospital, children who live in prison with their imprisoned parent, unaccompanied children and children outside their country of origin.

Abandoned children. This category includes children who found themselves deprived of a family environment for a variety of reasons, including social, economical, and social. For example, the collapse of the nuclear family, immigration, and runaway children. As a matter of general policy, the Committee has determined that States Parties have a general duty to care for these children, which includes taking 'all available measures to establish alternative care centres', and monitoring and evaluating the progress of these children in order to ensure their 'adequate development'. ${ }^{105}$

Furthermore, as a matter of general policy, with respect to any child who is deprived of her or his liberty, either in prison or in a detention centre due to her civil status (immigrant, stateless children, asylum-seeking children), States Parties have the duty to take 'into account the state of development' of such children. ${ }^{106}$ The conditions at detention centres should meet children's mental and physical health needs and accommodate their 'overall development'. ${ }^{107}$

Children who live in prison with their imprisoned parents. States Parties have the duty to ensure that their living conditions are 'adequate for the child's development', ${ }^{108}$ and suitable

\footnotetext{
${ }^{105}$ UNCRC 'Concluding Observations: Yemen' (1999), supra n. 74, paragraph 23.

${ }^{106}$ UNCRC 'Concluding Observations: Austria' (2005), supra n. 75, paragraph 48.

${ }^{107}$ UNCRC 'Concluding Observations: Australia' (20 October 2005) UN Doc CRC/C/15/Add. 268, paragraph 62.

${ }^{108}$ UNCRC 'Concluding Observations: Bolivia' (11 February 2005) UN Doc CRC/C/15/Add. 256, paragraph 40; UNCRC 'Concluding Observations: Islamic Republic of Iran' (31 March 2005) UN Doc CRC/C/15/Add. 254, paragraph 52; UNCRC 'Concluding Observations: Mexico' (2 June 2006) UN Doc CRC/C/MEX/CO/3, paragraph 40; UNCRC 'Concluding Observations: The Plurinational State of Bolivia' (16 October 2009) UN Doc CRC/C/BOL/CO/4, paragraph 65.
} 
for the child's 'needs for the harmonious development of his/her personality' ${ }^{109}$ More specifically, States Parties should ensure that these children are not 'deprived of their right to health and education which is inappropriate for their physiological and psychological development'. ${ }^{110}$ In the case of small children, these living conditions should be 'adequate for the child's early development'. ${ }^{111}$ While children of incarcerated parents who live with their parents get the chance to preserve the connection with their parents, the Committee concludes that this form of living can also have negative consequences on the development of children. Therefore, States Parties should establish institutional alternatives, such as foster families, as an alternative sending these children to live in prison. ${ }^{112}$ This kind of mechanism requires a placement process, which should be created and adapted with the aim to care for the child's development as well. ${ }^{113}$ In cases where children do end up being placed with foster families, they should be allowed to "maintain personal relations and direct contact with their mothers remaining in prison'. 114

Imprisoned children and children who live in other institutions. The Committee does not say much about these children, or about the effect that their family situation has on their development, and it has been satisfied with calling on States Parties to ensure that the 'adequate development' of these children be constantly monitored and evaluated while they live in institutions. ${ }^{115}$ Based on its view that children are better off living outside of institutions, the Committee suggests that States Parties develop alternative institutional care for imprisoned children or children who live in other institutions such as hospitals or orphanages. These institutions should be designed and run in a way that promotes the child's 'harmonious development and preparation for responsible participation in society'. ${ }^{116}$

Children who are imprisoned for their own crimes. This is a specific category of children deprived of a family environment. The Committee divides the care for these children's development into two categories: their development while in prison, and the care for their development upon their release. In light of Articles 37 and 40 of the Convention, the

\footnotetext{
${ }^{109}$ UNCRC 'Concluding Observations: Nepal' (2005), supra n. 98, paragraph 52.

${ }^{110}$ UNCRC 'Concluding Observations: Burundi' (2010), supra n. 36, paragraph 62.

${ }^{111}$ UNCRC 'Concluding Observations: Philippines' (21 September 2005) UN Doc CRC/C/15/Add. 259, paragraph 54.

${ }^{112}$ UNCRC 'Concluding Observations: Bolivia' (26 October 1998) UN Doc CRC/C/15/Add. 95, paragraph 23; UNCRC 'Concluding Observations: Bolivia' (2005), supra n. 108, paragraph 40.

${ }^{113}$ UNCRC ‘Concluding Observations: Lebanon' (8 June 2006) UN Doc CRC/C/LBN/CO/2, paragraph 44.

114 UNCRC 'Concluding Observations: Islamic Republic of Iran' (2005), supra n. 108, paragraph 52.

${ }^{115}$ UNCRC 'Concluding Observations: Nicaragua' (24 August 1999) UN Doc CRC/C/15/Add. 108, paragraph 31.

${ }^{116}$ UNCRC 'Concluding Observations: Uruguay’ (30 October 1996) UN Doc CRC/C/15/Add. 62, paragraph 23.
} 
Committee dedicated significant attention to the rights of imprisoned children, ${ }^{117}$ including General Comment number 10 (2007). ${ }^{118}$ The Committee did not, however, devote significant attention to the care for the development and right to development of these children.

In the first few comments relating to developmental issues of these children, the Committee mostly focused on 'adolescent health issues, including developmental, mental and reproductive health concerns and substance abuse...' of imprisoned children. ${ }^{119}$ Soon after, the Committee further added that these children should not be ill-treated and that States Parties should ensure 'that conditions in detention facilities are not contrary to the child's development'. ${ }^{120}$ In addition, imprisoned children should receive educational opportunities that will support, inter alia, their 'full development'. ${ }^{121}$ These kinds of programmes ought to be available to children upon their release from prison. ${ }^{122}$ General Comment 10 (2007) elaborated on young offenders' development. The General Comment emphasised the need to care for children's development, restating that 'one of the most important goals of the implementation of the CRC is to promote the full and harmonious development of the child's personality, talent and mental and physical abilities.' ${ }^{123}$ The Committee also states that 'it goes without saying that delinquency has a very negative impact on the child's development'. ${ }^{124}$ Recognizing the importance of development, the Committee further asked that policies responding to juvenile delinquency are designed in 'ways that support the child's development'. ${ }^{125}$ In particular, and on the bases of Article 37(a), States Parties should

\footnotetext{
117 See, for example, UNCRC 'Concluding Observations: Madagascar' (24 October 1994) UN Doc CRC/C/15/Add. 26, paragraph 22; UNCRC 'Concluding Observations: Philippines' (15 February 1995) UN Doc CRC/C/15/Add. 29, paragraph 8; UNCRC 'Concluding Observations: Jamaica' (1995), supra n. 69, paragraph 17; UNCRC 'Concluding Observations: Honduras' (24 August 1999) UN Doc CRC/C/15/Add. 105, paragraph 35

${ }^{118}$ UNCRC 'General Comment Number 10 - Children's Rights in Juvenile Justice' (25 April 2007) UN Doc $\mathrm{CRC} / \mathrm{C} / \mathrm{GC} / 10$.

${ }^{119}$ UNCRC 'Concluding Observations: Burkina Faso' (9 October 2002) UN Doc CRC/C/15/Add. 193, paragraph 40.

${ }^{120}$ UNCRC 'Concluding Observations: Venezuela' (5 October 2007) UN Doc CRC/C/VEN/CO/2, paragraph 77; UNCRC 'Concluding Observations: Sierra Leone' (20 June 2008) UN Doc CRC/C/SLE/CO/2, paragraph 77; UNCRC 'Concluding Observations: Chad' (2009), supra n. 88, paragraph 86; UNCRC 'Concluding Observations: Argentina' (11 June 2010) UN Doc CRC/C/ARG/CO/3-4, paragraph 79.

${ }^{121}$ UNCRC 'Concluding Observations: China' (24 November 2005) UN Doc CRC/C/CHN/CO/2, paragraph 93; UNCRC 'Concluding Observations: Mongolia' (21 September 2005) UN Doc CRC/C/15/Add. 264, paragraph 68; UNCRC 'Concluding Observations: Jordan' (29 September 2006) UN Doc CRC/C/JOR/CO/3, paragraph 95; UNCRC 'Concluding Observations: Kenya' (2007), supra n. 90, paragraph 68.

${ }^{122}$ UNCRC 'Concluding Observations: China' (2005), ibid; UNCRC 'Concluding Observations: Mongolia' (2005), ibid; UNCRC 'Concluding Observations: Jordan' (2006), ibid; UNCRC 'Concluding Observations: Kenya' (2007), supra n. 90, paragraph 68.

${ }^{123}$ UNCRC 'General Comment 10', supra n. 118, paragraph 16.

${ }^{124} \mathrm{Ibid}$, paragraph 11 .

${ }^{125}$ Ibid.
} 
consider the 'very negative consequences for the child's harmonious development' that imprisonment brings. ${ }^{126}$ Consequently, in order to ensure protection for the child's 'physical, psychological, mental and social development' professionals like police officers, prosecutors, judges and social workers should be trained accordingly. ${ }^{127}$

Unaccompanied children and children that are outside their country of origin. The Committee's recommendations concerning these children's development are similar to those we previously saw with respect to this category of children. In General Comment 6 (2005), the Committee determines that separated and unaccompanied children are:

'vulnerable to various risks that affect their life, survival and development, such as trafficking for purposes of sexual or other exploitation or involvement in criminal activities which could result in harm to the child, or in extreme cases, in death. Accordingly, Article 6 necessitates vigilance by States parties in this regard, particularly when organized crime may be involved." 128

The Committee further suggests that States Parties should take 'practical measures' in order to 'protect children from the risks' 129 while taking into account their 'state of development'. ${ }^{130}$ These measures should include, among other things, care for their accommodation, ${ }^{131}$ and ensuring an adequate standard of living for their 'physical, mental, spiritual and moral development' ${ }^{132}$

It is obvious that the Committee is deeply concerned with the impact that deprivation of family environment has on various developmental aspects (physical, psychological, mental and social) and forms ('early', 'harmonious', 'overall', and 'full' development) of children's development. However, none of these concerns, nor their consequent duties imposed on States Parties, are formulated in terms of caring for children's right to development. All these adjectives are vested with psychological jargon and derive from perception concerning the psychological effect that being deprived from family connection, and to lesser extent being imprisoned, have on children's mental health.

\footnotetext{
${ }^{126}$ Ibid.

${ }^{127}$ Ibid, paragraph 40 .

${ }^{128}$ UNCRC 'General Comment Number 6 - Treatment of Unaccompanied and Separated Children Outside Their Country of Origin' (1 September 2005) UN Doc CRC/GC/2005/6, paragraph 23.

${ }^{129} \mathrm{Ibid}$, paragraph 24.

${ }^{130}$ UNCRC 'Concluding Observations: Austria' (2005), supra n. 75, paragraph 48.

${ }^{131} \mathrm{Ibid}$, paragraph 40.

${ }^{132}$ Ibid, paragraph 44
} 
When reading the Committee's jurisprudence, it is obvious that it upholds developmental psychology as a normative framework to understand childhood, and to comment on family structures and child rearing practices. While the Committee's choice to use developmental psychology can be criticised, a larger problem liesin the way the Committee implements its conceptual framework. The Committee's view of the role of families and parents in caring for children's development is relatively clear. However, their role vis-à-vis the right to development of their children has been largely ignored. The question that should be asked at this stage, is whether the on-going emphasis on caring for children's development, while overlooking the child' right to development, is a result of a conscious choice, or a result of conceptual, normative and institutional limitations.

\section{Early Childhood Development}

The Committee has found great importance in caring for early childhood development, deeming this period as a critical moment 'for realising children's rights', ${ }^{133}$ due to the mental and social developmental stages that children are in during that time. The issue of early childhood development has gained significant attention in Concluding Observations, as well as in General Comment 7 (2005). The Committee's point of departure is that:

'Children experience the most rapid period of growth and change during the human lifespan, in terms of their maturing bodies and nervous systems, increasing mobility, communication skills and intellectual capacities, and rapid shifts in their interests and abilities... [they] form strong emotional attachments to their parents or other caregivers, from whom they seek and require nurturance, care, guidance and protection, in ways that are respectful of their individuality and growing capacities...

'In their early years, children also 'establish their own important relationships with children of the same age, as well as with younger and older children. Through these relationships they learn to negotiate and coordinate shared activities, resolve conflicts, keep agreements and accept responsibility for others... [they] actively make sense of the physical, social and cultural dimensions of the world they inhabit, learning progressively from their activities and their interactions with others, children as well as adults'. ${ }^{134}$

${ }^{133}$ UNCRC 'General Comment Number 7 - Implementing Child Rights in Early Childhood' (20 September 2006) UN Doc CRC/GC/2006/7/Rev.1, paragraph 6.

${ }^{134}$ Ibid. 
This statement recapitulates the Committee's perception about children's development. The Committee characterises the time of childhood as a time of growth and change, primarily which physical and mental developments. It is also evident that John Bowlby's attachment theory underpins the Committee's attitude to this subject. ${ }^{135}$ In a rather unusual manner, the Committee explained the basis for its position, reaffirming what already has been was concluded.

'The Committee notes the growing body of theory and research which confirms that young children are best understood as social actors whose survival, well-being and development are dependent on and built around close relationships. These relationships are normally with a small number of key people, most often parents, members of the extended family and peers, as well as caregivers and other early childhood professionals. At the same time, research into the social and cultural dimensions of early childhood draws attention to the diverse ways in which early development is understood and enacted, including varying expectations of the young child and arrangements for his or her care and education. A feature of modern societies is that increasing numbers of young children are growing up in multicultural communities and in contexts marked by rapid social change, where beliefs and expectations about young children are also changing, including through greater recognition of their rights. States parties are encouraged to draw on beliefs and knowledge about early childhood in ways that are appropriate to local circumstances and changing practices, and respect traditional values, provided these are not discriminatory, (article 2 of the Convention) nor prejudicial to children's health and well-being (art. 24.3), nor against their best interests (art. 3). Finally, research has highlighted the particular risks to young children from malnutrition, disease, poverty, neglect, social exclusion and a range of other adversities. It shows that proper prevention and intervention strategies during early childhood have the potential to impact positively on young children's current well-being and future prospects. Implementing child rights in early childhood is thus an effective way to help prevent personal, social and educational difficulties during middle childhood and adolescence. $^{, 136}$

In light of this approach, the Committee concluded that the early years of the child's life 'are the foundation for their physical and mental health, emotional security, cultural and personal identity, and developing competencies'. ${ }^{137}$ Perhaps more important is the Committee's claim that

\footnotetext{
${ }^{135}$ See John Bowlby, A Secure Base: Clinical Applications of Attachment Theory (Routledge, London 1988); Joseph Goldstein, Anna Freud, Sonja Goldstein and Albert Solnit, The Best Interests of the Child: The Least Detrimental Alternative (Simon\&Schuster, New York 1996).

${ }^{136}$ UNCRC 'General Comment 7', supra n. 133, paragraph 7. Emphasis added.

${ }^{137}$ Ibid, paragraph 6.
} 
'children's experiences of growth and development vary according to their individual nature, as well as their gender, living conditions, family organization, care arrangements and education system. Young children's experiences of growth and development are powerfully shaped by cultural beliefs about their needs and proper treatment, and about their active role in family and community'. ${ }^{138}$

Referring to Article 6 specifically, the Committee delineates the connection between development, the right to development and other rights of children.

'...ensuring survival and physical health are priorities, but States parties are reminded that article 6 encompass all aspects of development, and that a young child's health and psychosocial well-being are in many respects interdependent... The Committee reminds States parties (and others concerned) that the right to survival and development can only be implemented in a holistic manner,through the enforcement of all the other provisions of the Convention, including rights to health, adequate nutrition, social security, an adequate standard of living, a healthy and safe environment, education and play, as well as through respect for the responsibilities of parents and the provision of assistance and quality services. ${ }^{139}$

These statements are interesting for two reasons. First, they are one of the rare occasions in which the Committee explicitly mentions Article 6 and the need to protect the right to development, as opposed to the need to protect 'development'. Second, the Committee presents a relatively comprehensive perspective concerning various dimensions of the child's life, and the relevance of different dimensions of development to the realisation of the right to development, as well as other Convention's rights. However, the Committee mixes child survival, development, well-being and future prospects together, failing to distinguish between the meaning of these four concepts, or the obligations they impose on duty bearers in general, and on States Parties in particular. From these statements it is difficult to conclude what the differences are between these four concepts. But more importantly, despite the explicit references to the right to development and to the need to realise it in a holistic manner, it is not clear what, if any, is the added value of protecting the right to development over protecting other rights of the child, which are linked to children's development and are mentioned by the Committee.

\footnotetext{
${ }^{138}$ Ibid,paragraph 7.

${ }^{139}$ Ibid, paragraph 10. Emphasis added.
} 
In the Concluding Observations, the Committee tries to solidify its general approach, and to link between early childhood development and some rights of the child, but not the right to development. Most frequently, the Committee makes general statements about the significance of promoting early childhood development programmes, ${ }^{140}$ especially among low-income households, ${ }^{141}$ and about the need to educate parents about its importance. ${ }^{142}$ These kinds of programmes should target reducing infant and under-five mortality rates, providing universal immunization, ${ }^{143}$ and combating low birth weight ${ }^{144}$ (though it can be argued that these are issues governed by children's rights to life and survival). The Committee further concludes that early childhood development is threatened by early childhood diseases, such as acute respiratory infection and diarrhoea, ${ }^{145}$ chronic malnutrition $^{146}$ (which has 'serious consequences on health and psychological development'), ${ }^{147}$ vitamin A deficiency, ${ }^{148}$ anaemia, intestinal infectious diseases, bacterial infection, measles and pneumonia, ${ }^{149}$ malaria, ${ }^{150}$ poor situation of sanitation, insufficient access to clean and safe drinking water, ${ }^{151}$ and increasing the usage of effectively treated mosquito nets'. ${ }^{152}$ Institutional considerations should include maintaining sufficient numbers 'of trained health workers', ${ }^{153}$ 'baby friendly hospitals that do not separate new born babies

\footnotetext{
${ }^{140}$ UNCRC 'Concluding Observations: Jamaica' (1995), supra n. 69, paragraph 24.

${ }^{141}$ UNCRC 'Concluding Observations: Jordan' (28 June 2000) UN Doc CRC/C/15/Add. 125, paragraph 54.

${ }^{142}$ UNCRC 'Concluding Observations: Jamaica' (2010), supra n. 72, paragraph 61.

${ }^{143}$ UNCRC 'Concluding Observations: Nigeria' (2005), supra n. 68, paragraph 49; UNCRC 'Concluding Observations: Togo' (31 March 2005) UN Doc CRC/C/15/Add. 255, paragraph 50.

${ }^{144}$ UNCRC 'Concluding Observations: Hungary' (5 June 1998) UN Doc CRC/C/15/Add. 87, paragraph 2; UNCRC 'Concluding Observations: Togo', ibid, paragraph 50.

${ }^{145}$ UNCRC 'Concluding Observations: South Africa' (23 February 2000) UN Doc CRC/C/15/Add. 122, paragraph 29; UNCRC 'Concluding Observations: Haiti' (18 March 2003) UN Doc CRC/C/15/Add. 202, paragraph 44 .

${ }^{146}$ UNCRC 'Concluding Observations: Vanuatu' (1999), supra n. 81, paragraph 18; UNCRC 'Concluding Observations: Cameroon' (2001), supra n. 34, paragraph 42; UNCRC 'Concluding Observations: Burkina Faso' (2002), supra n. 119, paragraph 38; UNCRC 'Concluding Observations: Madagascar' (27 October 2003) UN Doc CRC/C/15/Add. 218, paragraphs 47-48.

${ }^{147}$ UNCRC 'Concluding Observations: Pakistan' (27 July 2003) UN Doc CRC/C/15/Add. 217, paragraph 53; UNCRC 'Concluding Observations: Togo' (2005), supra n. 143, paragraph 50; UNCRC 'Concluding Observations: Djibouti' (2008), supra n. 67, paragraph 30.

${ }^{148}$ UNCRC 'Concluding Observations: Haiti' (2003), supra n. 145, paragraph 44.

${ }^{149}$ UNCRC 'Concluding Observations: Nepal' (2005), supra n. 98, paragraph 60.

${ }^{150}$ UNCRC 'Concluding Observations: Mali' (2 November 1999) UN Doc CRC/C/15/Add. 113, paragraph 26.

${ }^{151}$ UNCRC 'Concluding Observations: Vanuatu' (1999), supra n. 81, paragraph 18; UNCRC 'Concluding Observations: Ivory Coast' (9 July 2001) UN Doc CRC/C/15/Add. 155, paragraphs 38-39; UNCRC 'Concluding Observations: Burkina Faso' (2002), supra n. 119, paragraph 38; UNCRC 'Concluding Observations: Haiti' (2003), supra n. 145, paragraph 44; UNCRC 'Concluding Observations: Swaziland' (16 October 2006) UN Doc CRC/C/SWZ/CO/1, paragraph 52.

${ }^{152}$ UNCRC 'Concluding Observations: Timor-Leste' (14 February 2008) UN Doc CRC/C/TLS/CO/1, paragraph 59 .

${ }^{153}$ UNCRC 'Concluding Observations: Vanuatu' (1999), supra n. 81, paragraph 18; UNCRC 'Concluding Observations: Marshal Islands' (19 November 2007) UN Doc CRC/C/MHL/CO/2, paragraph 50.
} 
from their mothers after birth', ${ }^{154}$ and ensuring equal access to health services, particularly in remote and rural areas. ${ }^{155}$

In recent years, the Committee emphasises the important of pre-school educationfor the promotion of children's development, ${ }^{156}$ thus expanding the scope of education beyond the primary school level included in the Convention. ${ }^{157}$ Pre-school programmes should 'address early childhood development holistically' ${ }^{158}$ and be designed 'in a culturally sensitive manner'. ${ }^{159}$ This sort of sensitivity is further stressed with respect to specific groups of children who need more assistance than other, including minority children, children with disabilities, ${ }^{160}$ and 'children growing up under economic hardship and deprivation'. ${ }^{161}$

Even though the Committee mostly uses needs discourse, most, if not all of these recommendations, can be articulated in human rights terms. These recommendations about early childhood development associate with the respect for the child's right to health, the right to social security, the right to adequate standard of living, the right to education, the right to playand leisure and the right to non-discrimination. ${ }^{162}$ According to the Committee's reasoning, promoting these rights will promote children's early development. In other words, as in the cases of the right to non-discrimination or the right to have a birth certificate, the Committee believes that promoting these rights is a precondition to promoting children's development.

\section{The Right to Health and Development}

Article 24 protects the child's right to health, and established number of entitlements for children. These entitlements are equal access to health care services, diminishing infant and

\footnotetext{
${ }^{154}$ UNCRC 'Concluding Observations: Republic Serbia' (2008), supra n. 34, paragraph 51.

155 UNCRC 'Concluding Observations: Hungary' (1998), supra n. 144, paragraph 18; UNCRC 'Concluding Observations: Vanuatu' (1999), supra n. 81, paragraph 18; UNCRC 'Concluding Observations: Columbia' (16 October 2000) UN Doc CRC/C/15/Add. 137, paragraph 45; UNCRC 'Concluding Observations: Ivory Coast' (2001), supra n. 151, paragraph 38; UNCRC 'Concluding Observations: Cameroon' (2001), supra n. 34, paragraph 42.

${ }^{156}$ UNCRC 'Concluding Observations: Libya Arab Jamahiriya' (4 July 2003) UN Doc CRC/C/15/Add. 209, paragraph 39; UNCRC 'Concluding Observations: Malaysia' (25 June 207) UN Doc CRC/C/MYS/CO/1, paragraph 79.

157 Article 28(1)(a) recognizes the right of children to education only from a primary school level.

${ }^{158}$ UNCRC ‘Concluding Observations: Bangladesh' (26 June 2009) UN Doc CRC/C/BGD/CO/4, paragraph 75;

UNCRC 'Concluding Observations: Bolivia' (2009), supra n. 108, paragraph 68.

${ }^{159}$ UNCRC 'Concluding Observations: Bolivia' (2009), supra n. 108, paragraph 68.

${ }^{160}$ UNCRC 'Concluding Observations: Bulgaria' (23 June 2008) UN Doc CRC/C/BGR/CO/2, paragraph 58.

${ }^{161}$ UNCRC 'Concluding Observations: Georgia' (23 June 2008) UN Doc CRC/C/GEO/CO/3, paragraph 57.

${ }^{162}$ UNCRC 'General Comment 7', supra n. 133, paragraph 10.
} 
child mortality, developing primary health care services, combating diseases and malnutrition and using technology to provide adequate food and clean drinking water, consideration of the risks of environmental pollution, ensuring pre and post natal health care for mothers, education and providing information on child health and nutrition, the advantages of breastfeeding, hygiene and environmental sanitation and prevention of accidents, and abolishing traditional practices. ${ }^{163}$ Article 24 does not mention children's development as an issue of concern, but, as we already have seen, the Committee hasmade a link between the child's right to health and children's development when referring to harmful traditional practices, and the need to guarantee equal access to health care.

When addressing the issues of child's health and its connection to child's development, the Committee highlighted several environmental hazards that have serious negative consequences for 'children's health and development'. This list includes water contamination, air pollution and environmental degradation, low availability of sanitation facilities and problems with industrial waste management. ${ }^{164}$ However, while the care for child's development is emphasised, the right to development is not mentioned in those remarks. In addition, considerable attention is given to two issues: children with HIV/AIDS and adolescent health, including dedicating two General Comments to them (General Comments 3 and 4, respectively). ${ }^{165}$

\section{Children with HIV/AIDS}

HIV/AIDS is a pandemic that affects the health of children who have it, as well as the lives of children who are born to or live in families where family member or members have HIV/AIDS. Therefore, the Committee is correctto suggest that HIV/AIDS affects all rights of children, including 'civil, political, economic, social and cultural ${ }^{166}$ rights. Therefore, the

\footnotetext{
163 Article 24(1)-(3).

${ }^{164}$ UNCRC 'Concluding Observations: Bangladesh' (2003), supra n. 34, paragraph 53. UNCRC 'Concluding Observations: Philippines' (2005), supra n. 111, paragraph 60; UNCRC 'Concluding Observations: Uzbekistan' (2 June 2006) UN Doc CRC/C/UZB/CO/2, paragraph 54; UNCRC 'Concluding Observations: Thailand' (2006), supra $\mathrm{n}$. 40, paragraph 55.

${ }^{165}$ UNCRC 'General Comment 3', supra n. 98; UNCRC 'General Comment 4 - Adolescent Health and Development in the Context of the Convention on the Rights of the Child' (1 July 2003) UN Doc

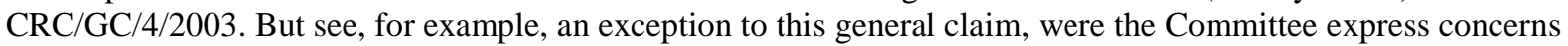
about the threat to children's health and development in Ukraine, due to the 'negative consequences of the Chernobyl nuclear plant disaster...'. UNCRC 'Concluding Observations: Ukraine' (9 October 2002) UN Doc CRC/C/15/Add. 191, paragraph 6.

166 UNCRC 'General Comment 3', supra n. 98, paragraph 5; UNCRC 'Concluding Observations: United Republic of Tanzania' (2001), supra n. 93, paragraph 30.
} 
Convention's four guiding principles, including the right to development, should 'be the guiding themes in the consideration of HIV/AIDS at all levels of prevention, treatment, care and support. ${ }^{167}$ In addition to this general statement, the Committee further emphasises the need to address specific rights. It includes:

'The right to access information and material aimed at the promotion of their social, spiritual and moral well-being and physical and mental health (Article 17); the right to preventive health care, sex education and family planning education and services (Article 24(f)); the right to an appropriate standard of living (Article 27); the right to privacy (Article 16); the right not to be separated from parents (Article 9); the right to be protected from violence (Article 19); the right to special protection and assistance by the State (Article 20); the rights of children with disabilities (Article 23); the right to health (Article 24); the right to social security, including social insurance (Article 26); the right to education and leisure (Articles 28 and $31)$; the right to be protected from economic and sexual exploitation and abuse, and from illicit use of narcotic drugs (Articles 32, 33, 34 and 36); the right to be protected from abduction, sale and trafficking as well as torture or other cruel, inhuman or degrading treatment or punishment (Articles 35 and 37); and the right to physical and psychological recovery and social reintegration (Articles 39)'. 168

The reason for bringing together this long list of rights under the umbrella of providing for children with HIV/AIDS is that "children are confronted with serious challenges to the abovementioned rights as a result of the epidemic.' ${ }^{169}$ Surprisingly enough, and despite the tendency to link almost every aspect of the child's life to development, neither development nor the right to development are included in this long list. Nevertheless, reflecting the description of Article 6 as representing a life-survival-development's continuum, ${ }^{170}$ the Committee states that "children have the right not to have their lives arbitrarily taken, as well as to benefit from economic and social policies that will allow them to survive into adulthood and develop in the broadest sense of the word'. ${ }^{171}$ The end of the process, therefore, could not be clearer, nor the embodiment of the 'human becomings' conception of childhood on the Committee's work. Unfortunately, the Committee once again failed to take this as an opportunity to address the question of how this conclusion can inform the meaning of the right to development.

\footnotetext{
${ }^{167}$ UNCRC 'General Comment 3', supra n. 98,paragraph 5.

${ }^{168}$ Ibid,paragraph 6.

${ }^{169}$ Ibid.

${ }^{170}$ See chapter two.

${ }^{171}$ UNCRC 'General Comment 3', supra n. 98, paragraph 11.
} 


\section{Adolescence Health and Development}

General Comment 4 is dedicated to the issue of 'adolescence health and development', thus emphasising the linkage between health and development. Perhaps more importantly, it is the attention given the fact that 'development' is not only an issue of babies or toddlers, but of children, adolescence included, in general. Similarly to the way in which the Committee characterizesthe period of early childhood, the time of adolescenceis also being conceptualisedusing the 'becomings' model. The Committee takes Article 5 and the evolving capacities principle as an underlying narrative of analysis, describing adolescence as a:

'Period characterized by rapid physical, cognitive and social changes, including sexual and reproductive maturation; the gradual building up of the capacity to assume adult behaviours and roles involving new responsibilities requiring new knowledge and skills. While adolescents are in general a healthy population group, adolescence also poses new challenges to health and development owing to their relative vulnerability and pressure from society, including peers, to adopt risky health behaviour...The dynamic transition period to adulthood is also generally a period of positive changes, prompted by the significant capacity of adolescents to learn rapidly, to experience new and diverse situations, to develop and use critical thinking, to familiarize themselves with freedom, to be creative and to socialize. ${ }^{172}$

The adolescent child is therefore situated in a unique mode of transition, from being a 'child' to becoming an 'adult'. This period of 'dynamic transition' requires, according to the Committee, interpreting Articles 6 and 24 'more broadly' ${ }^{173}$ in order to

'ensure that adolescents do enjoy the highest attainable standard of health, develop in a well-balanced manner, and are adequately prepared to enter adulthood and assume a constructive role in their communities and in society at large'. ${ }^{174}$

The Committee further stipulates the risk factors to adolescence health and development, and subsequently, the rights that ought to be protected in order to realise the right to development.

\footnotetext{
${ }^{172}$ UNCRC 'General Comment 4', supra n. 165, paragraph 2.

${ }^{173}$ Ibid, paragraph 4.

${ }^{174}$ Ibid.
} 
These risk factors are: discrimination; ${ }^{175}$ early marriage and pregnancy; injuries and death resulting from road traffic accidents; mental disorders and psychosocial illness, including depression, eating disorders and self-destructive behaviour (which can sometimes lead to self-inflicted injuries and suicide); and honour killing. ${ }^{176}$ Guaranteeing adolescents' right to health and development requires tackling these risk factors, as well as 'the promotion and enforcement of the provisions and principles of the Convention, especially Articles 2-6, 1217, 24, 28, 29 and 31. ${ }^{177}$ The Committee gives no explanations for these determinations, beyond a few general statements about the importance of respecting a certain right in order to realise the right to health and development. For example: 'The right to express views freely and have them duly taken into account is also fundamental in realizing adolescents' right to health and development'. ${ }^{178}$

Though the Committee did mention the issue of adolescence health prior to the publication of General Comment number $4,{ }^{179}$ it rarely linked it to adolescence's development. ${ }^{180}$ However, following the publication of General Comment 4 in 2003, many of the Concluding Observations referred to adolescent's development, but not to their right to development. But with few exceptions, these Concluding Observations mirror the conclusions of General Comment $4 .{ }^{181}$ In the exceptions, the Committee elaborated more about the issue. For example, the Committee concluded that in realising adolescent health, questions of sex, age and 'psychological development ${ }^{182}$ should be considered, and that the 'harmful effects of substance consumption on the physical, emotional and psychological development and

\footnotetext{
175 'Adolescents who are subject to discrimination are more vulnerable to abuse, other types of violence and exploitation, and their health and development are put at greater risk'. Ibid, paragraph 6.

${ }^{176} \mathrm{Ibid}$, paragraphs 20-22, 24.

${ }^{177} \mathrm{Ibid}$, paragraph 14.

${ }^{178} \mathrm{Ibid}$, paragraph8.

${ }^{179}$ See, for example, UNCRC 'Concluding Observations: Ecuador' (26 October 1998) UN Doc CRC/C/15/Add. 93, paragraph 23; UNCRC 'Concluding Observations: Kuwait' (26 October 1998) UN Doc CRC/C/15/Add. 96, paragraph 27.

${ }^{180}$ UNCRC 'Concluding Observations: Jordan' (2000), supra n. 141, paragraph 47.

${ }^{181}$ See, for example, UNCRC 'Concluding Observations: Morocco' (10 July 2003) UN Doc CRC/C/15/Add. 211, paragraph 46; UNCRC 'Concluding Observations: Zambia' (2003), supra n. 68, paragraph 48; UNCRC 'Concluding Observations: Antigua and Barbuda' (3 November 2004) UN Doc CRC/C/15/Add. 247, paragraph 53; UNCRC 'Concluding Observations: Democratic People's Republic of Korea' (2004), supra n. 70, paragraph 52; UNCRC 'Concluding Observations: Liberia' (1 July 2004) UN Doc CRC/C/15/Add. 236, paragraph 48; UNCRC 'Concluding Observations: Rwanda' (2004), supra n. 38, paragraph 50; UNCRC 'Concluding Observations: Benin' (2006), supra n. 90, paragraph 55; UNCRC 'Concluding Observations: Swaziland' (2006), supra n. 151, paragraph 55; UNCRC 'Concluding Observations: Columbia' (8 June 2006) UN Doc $\mathrm{CRC} / \mathrm{C} / \mathrm{COL} / \mathrm{CO} / 3$, paragraph 70; UNCRC 'Concluding Observations: Tanzania' (2006), supra n. 90, paragraph 47; UNCRC 'Concluding Observations: Kenya' (2007), supra n. 90, paragraph 50.

${ }^{182}$ UNCRC 'Concluding Observations: Romania' (30 June 2009) UN Doc CRC/C/ROM/CO/4, paragraph 69.
} 
wellbeing of children, ${ }^{183}$ should be taken into account (those are the rare occasions where the Committee explicitly refers to psychology). Likewise, mental health issues should also be taken into account, and assistance should be available to children 'in order to support their cognitive, social and emotional developmental needs'. ${ }^{184}$

The Committee's emphasis on adolescents' development is important for several reasons. Probably the most important one is the Committee's usage of rights discourse with relation to development. While the Committee usually speaks about children's 'development' as a description of children's organic conditions, in this case the Committee explicitly refers to the right to development. The Committee utilizes the evolving capacities principle and considers adolescence as a stage of childhood and, although this stage is not recognised by the Convention, the Committee analyses the characteristics of adolescence in light of this developmental stage. Consequently, the Committee specifies what the developmental needs of adolescents are, especially in relation to their health, and elaborate on what sort of rights these needs manifest. Once again, the Committee's reasoning shows that it is mostly concerned with the child's future, perceiving the right to development as a vehicle to ensure a 'healthy' process of growth, which should result in the creation of a 'healthy' adult.

\section{$\underline{\text { Poverty and Adequate Standard of Living }}$}

The child's right to an adequate standard of living is protected by Article 27, which offers the most comprehensive description of what 'children's development' stands for. The Article mandates that the child's right to a 'standard of living' should be adequate for the child's physical, mental, spiritual, moral and social development'. As such, the right to an adequate standard of living is not only an important right in itself, but, like other rights, is also perceived as a vehicle for promoting five dimensions of development. ${ }^{185}$ In its discussions about this right, the Committee focuses mostly on the connection between the living conditions of poor children and the impact these conditions have on development.

\footnotetext{
${ }^{183}$ UNCRC 'Concluding Observations: Democratic People's Republic of Korea' (27 March 2009) UN Doc $\mathrm{CRC} / \mathrm{C} / \mathrm{PRK} / \mathrm{CO} / 4$, paragraph 62.

${ }^{184}$ UNCRC 'Concluding Observations: Mongolia' (29 January 2010) UN Doc CRC/C/MNG/CO/3-4, paragraph 55.

${ }^{185}$ Compare to Article 25 of the Universal Declaration on Human Rights and Article 11 of the International Convention on Economic, Social and Cultural Rights. These two articles protect the right to an adequate standard of living and include different specifications and aims. In these articles of 'general' international law, the right includes, inter alia, the right to food, clothing and shelter. The impact of this desirable standard of living is not manifested in terms of the future benefit that the human person will have.
} 
The Committee has focused primarily on questions related to malnutrition and housing, and has been less concerned with intangible aspects of poverty ${ }^{186}$ (although Concluding Observations from 2010 onwards may signify a change in this respect). ${ }^{187}$ Time and again, the Committee determined that eliminating poverty and malnutrition and improving food security ${ }^{188}$ are needed in order to improve children's rights to survival, healthy development, education and wellbeing. ${ }^{189}$ It should also contribute to the child's 'full, ${ }^{190}$ and 'holistic development'. ${ }^{191}$ According to the Committee, the first step that States Parties ought to take in order to meet this requirement is to define a national poverty line, ${ }^{192}$ so that policies and programmes can be designed accordingly. ${ }^{193}$ On top of these recommendations, the Committee links children's material living conditions not only to their development, but also to their 'everyday quality of life' (though it does not specify what 'quality of life' stands for). ${ }^{194}$ On the basis of Article 27, the Committee then obliges States Parties to undertake even more duties to ensure children's social security net. Such a social security net should be available to children and:

'in light of articles 3, 4, 6, 26 and 27 of the Convention, the Committee encourages the State party to take all appropriate measures to the maximum extent of its available resources, in particular at the local level, to support families in a difficult economic and/or social situation in order to ensure, to the maximum extent possible, the survival and development of all children'. ${ }^{195}$

\footnotetext{
${ }^{186}$ For example,UNCRC 'Concluding Observations: Norway' (3 March 2010) UN Doc CRC/C/NOR/CO/4, paragraphs 46-47.

${ }^{187}$ See, for example, UNCRC 'Concluding Observations: Japan’ (20 June 2010) UN Doc CRC/C/JPN/CO/3, paragraphs 66-67.

${ }^{188}$ UNCRC ‘Concluding Observations: Sierra Leon’ (2008), supra n. 120, paragraph 29.

${ }^{189}$ UNCRC 'Concluding Observations: Honduras' (1994), supra n. 22, paragraph 15; UNCRC 'Concluding Observations: Bangladesh' (1997), supra n. 34, paragraph 21; UNCRC 'Concluding Observations: Austria' (7 May 1999) UN Doc CRC/C/15/Add. 98, paragraph 24; UNCRC 'Concluding Observations: Ethiopia' (21 February 2000) UN Doc CRC/C/15/Add. 144, paragraph 33; UNCRC 'Concluding Observations: Kenya' (2001), supra n. 93, paragraph 27; UNCRC 'Concluding Observations: Australia' (2005), supra n. 107, paragraph 56; UNCRC 'Concluding Observations: Ireland' (29 September 2006) UN Doc CRC/C/IRL/CO/2, paragraph 57; UNCRC 'Concluding Observations: Venezuela' (2007), supra n. 120, paragraph 65; UNCRC 'Concluding Observations: Djibouti' (2008), supra n. 67, paragraph 71. It is worth mentioning that at the early stages of its work, the Committee used to 'express concerns' about children's poverty and its impact on their health and education, but without linking it to their development. See, for example, UNCRC 'Concluding Observations: Bulgaria' (24 January 1997) UN Doc CRC/C/15/Add. 66, paragraph 16; UNCRC 'Concluding Observations: Ethiopia' (24 January 1997) UN Doc CRC/C/15/Add. 67, paragraph 12.

${ }^{190}$ UNCRC 'Concluding Observations: Spain' (29 September 2010) UN Doc CRC/C/ESP/CO/3-4, paragraph 52.

${ }^{191}$ UNCRC ‘Concluding Observations: Sudan' (1 October 2010) UN Doc CRC/C/SDN/CO/3-4, paragraph 60.

192 UNCRC 'Concluding Observations: Australia' (2005), supra n. 107, paragraph 56.

${ }^{193}$ UNCRC 'Concluding Observations: Lithuania' (21 February 2001) UN Doc CRC/C/15/Add. 146, paragraph 42.

${ }^{194}$ UNCRC 'Concluding Observations: Latvia' (21 February 2000) UN Doc CRC/C/15/Add. 142, paragraph 42.

195 UNCRC 'Concluding Observations: Latvia' (2001), ibid; See also UNCRC 'Concluding Observations: Georgia' (27 July 2003) UN Doc CRC/C/15/Add. 222, paragraph 54; UNCRC 'Concluding Observations:
} 
The Committee links children's best interests, the duty to realise social and economic rights gradually, children's rights to life, survival and development, the right to social security and the right to adequate standard of living together, in order to ensure children's 'survival and development'. However, like Article 11 of the ICESCR, the Committee mandates States Parties to support families, rather than support children. Nevertheless, in other comments the Committee rightly notes that some groups of children might not benefit from the support given to their families. ${ }^{196}$ However, the Committee does not provide a remedy for this inequality within the household. It is only in 2010 that the Committee began to promote the view that poverty reduction strategies should be developed with the active participation of children, ${ }^{197}$ a method that not only can could empower children, but also begin a process of eliminating intra-household discrimination. ${ }^{198}$

\section{Children who Work and/or Live on the Street}

One group of children who obviously do not enjoy the right to an adequate standard of living are children who live and/or work in the street. These children suffer from a multidimensional violation of their rights. Inter alia, they are deprived of a family environment, denied their rights to education, health, non-discrimination and freedom from economic exploitation and abuse (Articles 28-29, 24, 2 and 32 respectively), which further add to the negative impacts on their development. ${ }^{199}$ Therefore, the Committee has asked States Parties to provide these children with programmes that will 'enhance their living conditions and improve their development' ${ }^{200}$ On a more concrete basis, States Parties should provide for adequate nutrition, clothing, housing, health care and educational opportunities (including

Jamaica' (4 July 2003) UN Doc CRC/C/15/Add. 210, paragraph 46; UNCRC 'Concluding Observations: Angola' (2010), supra n. 33, paragraph 58.

${ }^{196}$ UNCRC 'Concluding Observations: France' (2004), supra n. 31, paragraph 46.

${ }^{197}$ UNCRC 'Concluding Observations: Tajikistan' (2010), supra n. 65, paragraph 59.

198 This issue is further discussed in chapter six.

${ }^{199}$ UNCRC 'Concluding Observations: Russian Federation' (1999), supra n. 42, paragraph 12; UNCRC 'Concluding Observations: Columbia' (16 October 2000) UN Doc CRC/C/15/Add. 137, paragraph 34; UNCRC 'Concluding Observations: Turkey' (2001), supra n. 101, paragraph 64; UNCRC 'Concluding Observations: Moldova' (31 October 2002) UN Doc CRC/C/15/Add. 192, paragraph 48; UNCRC 'Concluding Observations: Zambia' (2003), supra n. 68, paragraph 69; UNCRC 'Concluding Observations: Estonia' (2003), supra n. 43, paragraph 45; UNCRC 'Concluding Observations: India' (2004), supra n. 34, paragraph 77; UNCRC 'Concluding Observations: Mongolia' (2002), supra n. 121, paragraph 63; UNCRC 'Concluding Observations: Azerbaijan' (17 March 2006) UN Doc CRC/C/AZE/CO/2, paragraph 64; UNCRC 'Concluding Observations: Venezuela' (2007), supra n. 120, paragraph 73.

${ }^{200}$ UNCRC 'Concluding Observations: The Former Yugoslav Republic of Macedonia' (11 June 2010) UN Doc $\mathrm{CRC} / \mathrm{C} / \mathrm{CO} / 2$, paragraph 72 . 
vocational and life-skills training), ${ }^{201}$ access to rehabilitation services for physical, sexual and substance abuse, protection from police brutality, services for reconciliation with their families', ${ }^{202}$ and 'official documents when necessary'. ${ }^{203}$ All of these services are needed in order to support the 'full development' ${ }^{204}$ of street children. But the Committee neither elaborates on what qualifies as 'full development', nor does it refer to the right to development of these children.

Nevertheless, the Committee's jurisprudence concerning adequate standard of living and its impact on the child's development is exceptional, since the Committee not only identifies some institutional situations that interfere with children's development, but also stipulates specific aspects of development (with the exception of street children and the care for their 'full development'). Thisdefinition of an adequate standard of living means that realising this right serves a greater good, which is the promotion of children's physical, mental, spiritual, moral and social development.

\section{Education}

The Convention protects children's right to education and defines the aims of education in Articles 28 and 29, respectively. The Convention states that the right to education should be available to all children on the bases of equal opportunity, ${ }^{205}$ from the stage of primary education, ${ }^{206}$ and all the way up to higher education. ${ }^{207}$ Children's development occupies a significant part of the aims of education as set forth in Article 29. Conceiving of the conception of childhood as a time of change and growth, Article 29(1)(a) defines the first aim

\footnotetext{
${ }^{201}$ UNCRC 'Concluding Observations: Turkey' (2001), supra n. 101, paragraph 64.

202 UNCRC 'Concluding Observations: Turkey' (2001), supra n. 101, paragraph 64; See also UNCRC 'Concluding Observations: Kuwait' (1998), supra n. 179, paragraph 25; UNCRC 'Concluding Observations: Moldova' (2002), supra n. 199, paragraph 48; UNCRC 'Concluding Observations: Zambia' (2003), supra n. 68, paragraph 69; UNCRC 'Concluding Observations: Estonia' (2003), supra n. 43, paragraph 45; UNCRC 'Concluding Observations: Mongolia' (2005), supra n. 121, paragraph 63; UNCRC 'Concluding Observations: Azerbaijan' (2006), supra n. 199, paragraph 64.

${ }^{203}$ UNCRC 'Concluding Observations: India' (2004), supra n. 34, paragraph 77.

${ }^{204}$ UNCRC 'Concluding Observations: Turkey' (2001), supra n. 101, paragraph 65; UNCRC 'Concluding Observations: Moldova' (2002), supra n. 199, paragraph 48; UNCRC 'Concluding Observations: Zambia' (2003), supra n. 68, paragraph 69; UNCRC 'Concluding Observations: Estonia' (2003), supra n. 43, paragraph 45; UNCRC 'Concluding Observations: India' (2004), supra n. 34, paragraph 77; UNCRC 'Concluding Observations: Mongolia' (2005), supra n. 121, paragraph 63; UNCRC 'Concluding Observations: Burkina Faso' (29 January 2010) UN Doc CRC/C/BFA/CO/3-4, paragraph 71; UNCRC 'Concluding Observations: Paraguay' (2010), supra n. 72, paragraph 69.

205 Article 28(1).

${ }^{206}$ Article 28(1)(a).

207 Article 28(1)(d).
} 
of education as 'the development of the child's personality, talent and mental and physical abilities to their fullest potential'. Marking the end of the development process as the facilitation of the child's 'fullest potential', is the only place in the Convention where a suggestion about the outcome of development is made.

The Committee's extensive jurisprudence on education derives from the view that education is vital to promoting several aspects of children's development. The Committee recommends that educational opportunities be available to children as early as possible, writing that 'the right to education during early childhood as beginning at birth and closely linked to young children's right to maximum development (Article 6.2)' ${ }^{208}$ The Committee further adds that implementing the right to education for young children should be done in 'a holistic approach to early childhood development' ${ }^{209}$

One of the preconditions for fulfilling the right to education is that children will have access to schools. ${ }^{210}$ Therefore, it is the State Party's responsibility to ensure school attendance of children, including actively promoting the attendance of girls and other disempowered groups. ${ }^{211}$ States Parties should also address school drop-out rates, since absenteeism has a negative impact on children's 'development and future access to employment'.212 Availability of education also requires that education be provided free of cost, ${ }^{213}$ including waiver from payment of a 'voluntary quota' and/or school' books or other school material. States Parties should also provide sufficient support to families with financial problems, so these families are able to support the 'adequate educational development of their children'. ${ }^{214}$ After access and accessibility to school have been established, we can turn to the schools' environment. In that regard, the Committee concludes that school should be free from violence, including bullying, since this practice affects children's 'psychological health, educational achievements and social development'. ${ }^{215}$

\footnotetext{
${ }^{208}$ UNCRC, 'General Comment 7', supra n. 133, paragraph 28. See also the discussion about early childhood and development.

${ }^{209}$ UNCRC 'Concluding Observations: El Salvador' (17 February 2010) UN Doc CRC/C/SLV/CO/3-4, paragraph 68 .

210 Realizing the right to education requires much more, mainly the four A's: Availability, Accessibility, Acceptability and Adaptability. The Committee has addressed these aspects as part of its monitoring the implementation of Article 28. I refer only to the links the Committee made between the realisation of the right to education and development.

${ }^{211}$ UNCRC 'Concluding Observations: Brazil' (3 November 2004) UN Doc CRC/C/15/Add. 241, paragraph 58. ${ }^{212}$ UNCRC 'Concluding Observations: Finland' (20 October 2005) UN Doc CRC/C/15/Add. 272, paragraph 42.

${ }^{213}$ Article 28(1)(a).

${ }^{214}$ UNCRC 'Concluding Observations: Nicaragua' (21 September 2005) UN Doc CRC/C/15/Add. 265, paragraph 58 .

${ }^{215}$ UNCRC 'Concluding Observations: Australia' (2005), supra n. 107, paragraph 60.
} 
The issue of children's development, as opposed to their right to development, gained more attention when the Committee addressed the aims of education. The Committee dedicated its first General Comment to this subject, ${ }^{216}$ stating that education should:

'Promote, support and protect the core value of the Convention: the human dignity innate in every child and his or her equal and inalienable rights. These aims, set out in the five subparagraphs of article 29 (1) are all linked directly to the realization of the child's human dignity and rights, taking into account the child's special developmental needs and diverse evolving capacities. The aims are: the holistic development of the full potential of the child ...,217

Education, therefore, should be:

'Designed to provide the child with life skills, to strengthen the child's capacity to enjoy the full range of human rights and to promote a culture which is infused by appropriate human rights values. The goal is to empower the child by developing his or her skills, learning and other capacities, human dignity, self-esteem and self-confidence. "Education" in this context goes far beyond formal schooling to embrace the broad range of life experiences and learning processes which enable children, individually and collectively, to develop their personalities, talents and abilities and to live a full and satisfying life within society. ${ }^{218}$

Commenting specifically on the first aim of education, the Committee added that:

'Insists upon a holistic approach to education which ensures that the educational opportunities made available reflect an appropriate balance between promoting the physical, mental, spiritual and emotional aspects of education, the intellectual, social and practical dimensions, and the childhood and lifelong aspects. The overall objective of education is to maximize the child's ability and opportunity to participate fully and responsibly in a free society. It should be emphasized that the type of teaching that is focused primarily on accumulation of knowledge, prompting competition and leading to an excessive burden of work on children, may seriously hamper the harmonious development of the child to the fullest potential of his or her abilities and talents' ${ }^{219}$

The aims of the education process are defined in broad terms that establish a strong connection between education and the child's ability to enjoy harmonious development, and realise her fullest potential. The Committee, however, does not link the aims of education to

\footnotetext{
${ }^{216}$ UNCRC 'General Comment 1', supra n. 17.

${ }^{217}$ Ibid. Emphasis added.

${ }^{218}$ Ibid, supra n. 17.

${ }^{219}$ Ibid, emphasis added. See also UNCRC 'Concluding Observations: Romania' (18 March 2003) UN Doc CRC/C/15/Add. 199, paragraph 53. Emphasis added.
} 
the child's right to development, but rather it is more concerned with supporting the child's psychological development. In similarity to its interpretation to other rights in the Convention, the Committee interprets the right to education as a vehicle to promote a greater good. I.e., the full realisation of the child's potential.

In is with these perceptions that the Committee monitors the implementation of Articles 2829. The Committee, by restating Article 29(1), continually emphasizes that education should be directed towards the development 'of the child's personality, talent and mental and physical abilities to their fullest potential'. ${ }^{20}$ The Committee adds that school's curricula should address 'all-round development', ${ }^{221}$ 'focus on the personal development and vocational training' of students, ${ }^{222}$ and promote children's 'cognitive, social and emotional development'. ${ }^{223}$ Nevertheless, while encouraging students to achieve their potential, the Committee calls schools not to create too competitive atmosphere between pupils, since such an environment can place 'additional burdens on children and may hamper the development of the child to her or his fullest potential', ${ }^{224}$ and may also expose children 'to developmental disorders'. ${ }^{225}$ Such an environment, as well as long school hours, can also prevent children from spending time pursuing 'leisure, physical activities and rest', and, therefore, frustrate their development. ${ }^{226}$ These statements reinforce the claim that the Committee's perception of children's development is entrenched in mainstream developmental psychology and with Western perception of childhood. While the Committee asked to advance the development of children's potential, it flinched from educational practices that 'push' the child too much and thus, pose a risk to the fragile process of development.

The right to rest and leisure, as protected in Article 31, gains attention in the context of education. As the Committee does with respect to most of the Convention's rights, the implementation of right is also being assessed based on the contribution to children's development. For example, the Committee asks States Parties to educate parents about 'the

\footnotetext{
${ }^{220}$ See, for example, UNCRC 'Concluding Observations: Slovakia' (23 October 2000) UN Doc CRC/C/15/Add. 140 , paragraph 46.

${ }^{221}$ UNCRC 'Concluding Observations: China' (2005), supra n. 121, paragraph 77.

${ }^{222}$ UNCRC 'Concluding Observations: Macedonia' (23 February 2000) UN Doc CRC/C/15/Add. 118, paragraph 45

${ }^{223}$ UNCRC 'Concluding Observations: Poland' (30 October 2002) UN Doc CRC/C/15/Add. 194, paragraph 45.

${ }^{224}$ UNCRC 'Concluding Observations: Thailand' (2006), supra n. 40, paragraph 64.

${ }^{225}$ UNCRC 'Concluding Observations: Japan' (1998), supra n. 75, paragraph 22; UNCRC 'Concluding Observations: Singapore' (27 July 2003) UN Doc CRC/C/15/Add. 220, paragraph 42; UNCRC 'Concluding Observations: Republic of Korea' (18 March 2003) UN Doc CRC/C/15/Add. 197, paragraph 52; UNCRC 'Concluding Observations: Japan' (26 February 2004) UN Doc CRC/C/15/Add. 231, paragraph 49; UNCRC 'Concluding Observations: Thailand' (2006), supra n. 40, paragraph 65.

${ }^{226}$ UNCRC ‘Concluding Observations: Japan' (1998), supra n. 75, paragraph 22.
} 
importance of these activities for the development of the child'. ${ }^{227}$ Alongside the role of parents, States Parties themselves have a duty to 'pay adequate attention to planning leisure and cultural activities for children... taking into consideration the physical and psychological development of the child'. ${ }^{228}$ Leisure time programmes should not be limited to playground, and also include cultural activities, which are needed for 'the physical and psychological development of the child'. ${ }^{229}$ Opportunities to play should be available 'particularly [to] those under the age of two years [because such opportunities] have a crucial bearing on the development of the child's cognitive abilities and their social and emotional development'.230 Children should have the opportunity to play with other children, as well as with their mothers, since mother-child activities 'have a crucial bearing on the development of the child's. ${ }^{231}$ This comment was followed with a more gender neutral one, stating that parentchildren activities, ${ }^{232}$ and not only mother-child activities, have a crucial bearing on the development of children.

Another right of children that is linked to their rights to education and leisure time is the right to information. Article 17 recognises the child's right to receive information, stating that it is important for children's 'social, spiritual, and moral wellbeing and physical and mental health'. The Committee asks if any and all kinds of information promote this goal, concluding that the answer is 'no'. On the one hand, the Committee denounces States Parties where the media abuses children to the 'detriment of their personality and status as minors', ${ }^{233}$ primarily as exposure can injure 'their wellbeing and development'. States Parties are therefore required to take measures to protect children from 'harmful effects of the print, electronic and audio-visual media, in particular violence and pornography'. ${ }^{234}$ On the other hand, the Committee asks States Parties to take measures that will enable children to access

227 UNCRC 'Concluding Observations: Mauritania' (6 November 2001) UN Doc CRC/C/15/Add. 159, paragraph 46.

${ }_{228}^{22}$ UNCRC 'Concluding Observations: Benin' (2006), supra n. 90, paragraph 64; UNCRC 'Concluding Observations: Lithuania' (17 March 2006) UN Doc CRC/C/LTU/CO/2, paragraph 59.

${ }^{229}$ UNCRC 'Concluding Observations: Lithuania' (2001), supra n.193, paragraph 46.

${ }^{230}$ UNCRC 'Concluding Observations: Belize' (10 May 1999) UN Doc CRC/C/15/Add. 99, paragraph 23.

${ }^{231}$ Ibid.

${ }^{232}$ UNCRC 'Concluding Observations: Mauritania' (2001), supra n. 227, paragraph 46.

${ }^{233}$ UNCRC 'Concluding Observations: Nicaragua' (1995), supra n. 41, paragraph 17.

${ }^{234}$ UNCRC 'Concluding Observations: Federated State of Micronesia' (4 February 1998) UN Doc CRC/C/15/Add. 86, paragraph 16; UNCRC 'Concluding Observations: Canada' (1995), supra n. 35, paragraph 15; UNCRC 'Concluding Observations: Trinidad and Tobago' (10 October 1997) UN Doc CRC/C/15/Add. 82, paragraph 15; UNCRC 'Concluding Observations: Lithuania' (2001), supra n. 193, paragraph 28; UNCRC 'Concluding Observations: Kazakhstan' (19 June 2007) UN Doc CRC/C/KAZ/CO/3, paragraph 32; UNCRC 'Concluding Observations: Mongolia' (2010), supra n. 184, paragraph 35. 
information, especially in libraries, ${ }^{235}$ that can promote their 'development and physical and mental health', ${ }^{236}$ as well as their 'cultural development'. ${ }^{237}$

A comprehensive perception of education includes access to education, the aims of education, school atmosphere, children's leisure time and the kind of information and messages that they are exposed to. Most, if not all, of these aspects are linked to children's rights by the Committee, as well as to various domains of children's development. These different aspects are described as either having an impact on them, or as essential for their realisation. The Committee perceives education as a fundamental factor in promoting children's harmonious development and the realisation of their 'maximum' potential. But it is only early childhood education opportunities that the Committee has linked to the child's right to development, while in general it employed the psycho-social development vocabulary, ignoring the articulation of development as a human rights of children.

\section{$\underline{\text { Armed Conflicts }}$}

Armed conflicts violate number of human rights of all people who are involved in them, both directly and indirectly, including children. Children can become victims of armed conflicts in different ways, ranging from being forcibly recruited to armed groups (either by official states' army or by other militias), suffering injury or death, or losing family members, to a secondary consequences, such as not having access to health care or education services. ${ }^{238}$ In light of Articles 38-39 of the Convention, the Committee focuses its attention on children who are victims of wars, including child soldiers. As of 2002, the rights of these children are primarily discussed as part of the monitoring processes of the Optional Protocol on the Involvement of Children in Armed Conflict. ${ }^{239}$ Therefore, the Concluding Observations on the implementation of the Convention published since 2002 give less attention to children in situations of armed conflict.

\footnotetext{
${ }^{235}$ UNCRC 'Concluding Observations: The Democratic Republic of Congo' (2006), supra n. 44, paragraph 35.

${ }^{236}$ UNCRC 'Concluding Observations: Marshall Island' (16 October 2000) UN Doc CRC/C/15/Add. 139, paragraph 34; UNCRC ‘Concluding Observations: Spain' (2010), supra n. 190, paragraphs 31-33.

${ }_{237}^{23}$ UNCRC 'Concluding Observations: Lebanon' (7 June 1996) UN Doc CRC/C/15/Add. 54, paragraph 36.

238 See, for example, UNCRC 'Concluding Observations: Ecuador' (29 January 2010) UN Doc $\mathrm{CRC} / \mathrm{C} / \mathrm{ECU} / \mathrm{CO} / 4$, paragraph 68 .

${ }^{239}$ GA Resolution A/RES/54/263 (20 May 2000), entered into force on 12 February 2002.
} 
In general, the Committee is concerned with the impact that 'an atmosphere of violence' has on children's 'development and right to life', ${ }^{240}$ as well as with the impact that armed conflicts have on children's rights to survival and development. ${ }^{241}$ The Committee has paid particular attention to one kind of weapon - land mines - that pose a 'threat... to the survival and development of children. ${ }^{242}$ Troubled by the "psychological trauma'243 that armed conflicts cause for children, the Committee has asked States Parties to ensure the protection and rehabilitation of children. Children therefore should receive 'adequate assistance and counselling for their rehabilitation, physical and psychological recovery and social integration'. ${ }^{244}$ In a highly unusual manner, the right to development of children is mentioned by name, but no discussion about its meaning follows. A possible explanation to this omission, is that the Committee's concern lies with the emotional trauma that such conflict causes, hence taking for granted the assumption that a discussion about children's development uphold psychological definition of this term.

\section{$\underline{\text { Labour and Exploitation }}$}

Article 32 of the Convention protects the right of children 'to be protected from economic exploitation and from performing any work that is likely to be hazardous or to interfere with the child's education, or to be harmful to the child's health and physical, mental, spiritual, moral or social development'. The article does not define what child labour means, nor does it protect children from any kind of work other than occupations that might be harmful to five domains of developmental: physical, mental, spiritual, moral or social. These are the same five domains that Article 27 names.

\footnotetext{
${ }^{240}$ UNCRC 'Concluding Observations: Peru' (2000), supra n. 73, paragraph 18.

${ }^{241}$ UNCRC 'Concluding Observations: India' (23 February 2000) UN Doc CRC/C/15/Add. 115, paragraph 63; UNCRC 'Concluding Observations: Burundi' (2000), supra n. 32, paragraph 30; UNCRC 'Concluding Observations: Democratic Republic of Congo' (9 July 2001) UN Doc CRC/C/15/Add. 153, paragraph 26; UNCRC 'Concluding Observations: India' (2004), supra n. 34, paragraph 68; UNCRC 'Concluding Observations: Algeria' (12 October 2005) UN Doc CRC/C/15/Add. 269, paragraph 70; UNCRC 'Concluding Observations: Democratic Republic of the Congo' (10 February 2009) UN Doc CRC/C/COD/CO/2, paragraph 33; UNCRC 'Concluding Observations: Pakistan' (15 October 2009) UN Doc CRC/C/PAK/CO/3-4, paragraph 35; UNCRC 'Concluding Observations: The Philippines' (22 October 2009) UN Doc CRC/C/PHL/CO/3-4, paragraph 32; UNCRC 'Concluding Observations: Nigeria' (2010), supra n. 88, paragraph 80.

${ }^{242}$ UNCRC 'Concluding Observations: Iraq' (26 October 1998) UN Doc CRC/C/15/Add. 94, paragraph 28; UNCRC 'Concluding Observations: Angola' (3 November 2004) UN Doc CRC/C/15/Add. 246, paragraph 62; UNCRC 'Concluding Observations: Jordan' (2006), supra n. 121, paragraph 77.

${ }^{243}$ UNCRC 'Concluding Observations: Columbia' (2000), supra n. 199, paragraph 34.

${ }^{244}$ UNCRC 'Concluding Observations: Angola' (2005), supra n. 241, paragraph 71.
} 
The Committee does not add much to what is explicitly set out in this clause. In most of the Concluding Observations that mention child labour, the Committee repeated the language of the Convention and is content with calling on States Parties to 'combat economic exploitation' that can be 'harmful to the child's health or physical, mental, spiritual, moral or social development'. ${ }^{245}$ Article 32 does not set a minimum age for employment, but in order to meet its stated aims. The Committee requires States Parties, among other things, to 'provide for a minimum age or minimum ages for admission for employment', ${ }^{246}$ and regulate the working hours and working conditions of children.

Only in General Comment 11, published in 2009, did the Committee define child labour, stating that "child labour is work that deprives children of their childhood, their potential and dignity and that is harmful to their physical and mental development' ${ }^{247}$ Exploitation or inadequate working hours and conditions are also an issue for household-type work. Therefore, the Committee further asks States Parties to pay attention to the 'conditions of children working within their families, in order to protect them fully'. ${ }^{248}$ Similar concerns are expressed with regard to child domestic workers. ${ }^{249}$ Long working hours are another source of concern because they have a negative impact not only on a child's school attendance, but also on her 'development' ${ }^{250}$ or 'full and harmonious development'. ${ }^{251}$

The Committee also calls on States Parties to narrow the gap between the age at which compulsory education ends and the minimum legal age for access to employment, ${ }^{252}$ because this gap opens the door for illegal employment practices, and can lead to situations of abuse

\footnotetext{
${ }^{245}$ UNCRC 'Concluding Observations: Laos' (10 October 1997) UN Doc CRC/C/15/Add. 78, paragraph 50; UNCRC 'Concluding Observations: Federated State of Micronesia' (1998), supra n. 234, paragraph 39; UNCRC 'Concluding Observations: Fiji' (1998), supra n. 75, paragraph 42; UNCRC 'Concluding Observations: Costa Rica' (24 February 2000) UN Doc CRC/C/15/Add. 117, paragraph 26; UNCRC 'Concluding Observations: Central African Republic' (2000), supra n. 95, paragraph 78; UNCRC 'Concluding Observations: Ukraine' (2002), supra n. 165, paragraph 65; UNCRC 'Concluding Observations: Czech Republic ' (2003), supra n. 72, paragraph 59; UNCRC 'Concluding Observations: Ghana' (17 March 2006) UN Doc CRC/C/GHA/CO/2, paragraph 65.

${ }^{246}$ Article 32(2)(a).

${ }^{247}$ UNCRC, 'General Comment 11', supra n. 18, paragraph 69.

${ }^{248}$ UNCRC 'Concluding Observations: Fiji' (1998), supra n. 75, paragraph 42.

${ }^{249}$ UNCRC 'Concluding Observations: Malaysia' (2007), supra n. 156, paragraph 91.

${ }^{250}$ UNCRC 'Concluding Observations: Central African Republic' (2000), supra n. 95, paragraph 78; UNCRC 'Concluding Observations: Cameroon' (2001), supra n. 34, paragraph 58; UNCRC 'Concluding Observations: Moldova' (2002), supra n. 199, paragraph 43; UNCRC 'Concluding Observations: Madagascar' (2003), supra n. 199, paragraph 59; UNCRC 'Concluding Observations: Nigeria' (2005), supra n. 68, paragraph 75.

${ }^{251}$ UNCRC 'Concluding Observations: Jamaica' (2003), supra n. 195, paragraph 51.

${ }^{252}$ UNCRC 'Concluding Observations: Nicaragua' (1995), supra n. 41, paragraph 14; UNCRC 'Concluding Observations: Senegal' (1995), supra n. 33, paragraph 11; UNCRC 'Concluding Observations: Iraq' (1998), supra n. 242, paragraph 26; UNCRC 'Concluding Observations: Madagascar' (2003), supra n. 146, paragraph 59.
} 
and exploitation. No impact on the right to development is mentioned, nor is any explanation regarding the connection between labour and various aspects of development given.

\section{Analysis - Much Ado About Nothing}

Almost twenty years of monitoring the implementation of the Convention's protection of the right to development has resulted in a long and detailed catalogue. This catalogue connects almost every aspect of the child's life and most of the Convention's rights to various domains of children's development, and includes only a handful of comments about the right to development, its connection to other rights of the child or its intrinsic meaning. The extent to which the Committee emphasises the need to protect children's development highlights the absence of a meaningful body of jurisprudence concerning the right to development. Similar to its treatment in the Convention's drafting process, the child's right to development remained in the shadow of the care for children's development in the Committee's jurisprudence.

The tendency to overlook the right to development while focusing on children's psychosocial development or the other two rights protected by Article 6 (the right to life and the right to survival) is evident in the substance of the Committee's work, and in the more technical aspects of its work, which indicate a much deeper conceptual problem. As mentioned at the beginning of this chapter, the Committee's reporting guidelines ask States Parties to elaborate on the steps taken for implementing the Convention's guiding principles, including the rights to life, survival and development. Likewise, the Concluding Observations and General Comments use formats that include a section concerning the implementation of those general principles. Indeed, most of the Concluding Observations and General Comments do refer to Article 6, but only a handful of them refer to the right to development. Even the headlines used for the section about Article 6 illustrate the on-going ignorance of the right to development. While the majority of the 364 Concluding Observations reviewed in this research use the title 'Article 6 - the Right to Life, Survival and Development', the subsequent section does not refer to the right to development at all. A few of the headlines read 'Article 6 - the right to life' only, omitting the right to development. Only a few dozens of the Concluding Observations refer to the right to development in both the heading and the content. I believe that this pattern is not arbitrary, but rather reflects a conceptual failure to engage with the right to development. 
There is a lack of conceptual clarity with regard to the meaning of 'children's development' in the Committee's jurisprudence. Not only does the Committee never explain how it understands this term, it is evident from this analysis that the Committee does not hold a clear and coherent understanding. The Committee refers to different domains of children's development, such as mental development, physical development, social development, as well as to more descriptive terms such as 'full' or 'harmonious' development. But it does not explain their meaning or how they relate to human rights language, discourse and tools. When the Committee refers to children's development, it does so either to highlight the risk factors that can damage these domains of development, or in order to suggest how they should be supported. This is where the conceptual ambiguity, which the Committee shares with the Convention's drafters, ${ }^{253}$ arises: the meaning of these domains of children's development is not self-evident, and different disciplines understand them differently. Moreover, even within a single discipline, such as psychology, there can be different understandings of what 'development' means. As noted in previous chapters, Freud's understanding of children's development, for example, is different from Piaget's, thought they both speak about developmental psychology. Needless to say, the difference in meaning leads to different means required to support 'development'. Therefore, when the Committee speaks of the need to support children's mental development, the discussion is only valid as the validity of the stream of psychology it employs. But the Committee does not say what stream of psychology it employs, nor how it understands the term 'children's development' in general.

The Committee interprets most of the Convention's rights in one of two ways. The Committee either takes protection of right $\mathrm{X}$, for example the right to non-discrimination, as a precondition necessary for protecting one or more aspects of children's development. Or, alternatively, the Committee views the protection of right $\mathrm{X}$, for example the right to education, as a necessary part of protecting one or more aspects of children's development. Neither of these two approaches provides a distinct meaning for the right to development.

Where the Committee does refer to the right to development, it is very difficult to draw any conclusions regarding the meaning of the right. The Committee does not clarify what the right to development should stand for, what it protects (the process of development, the outcome of it, or maybe both?), what its aims are, or what, if any, are its added values in comparison to other rights of the Convention. This ambiguity is the result of two factors. The

253 See chapter two. 
first has already been mentioned, and it is the conceptual ambiguity of the term 'development'. The second factor is because by in large, the Committee's work is dominated by the traditional binary conception of childhood as a time of 'becomings', and therefore the Committee is unable or unwilling to divert from this 'romantic developmentalism" 254 approach. As the Committee's approach is embedded with this conception of childhood, in its jurisprudence it cares for children's future and, thus, subjugates most of the Convention's rights to support 'children's development'.

Another implication of employing the 'human becomings' approach is the denial of children's agency. While the Committee links most of the Convention's rights to children's development, including rights not mentioned in the Convention such as the right to freedom of movement, ${ }^{255}$ it ignores two of the Convention's rights: the right to freedom of expression and the right to participation (Articles 13 and 12, respectively). ${ }^{256}$ The Committee neglects these two rights, one of which is a guiding principle of the Convention, ${ }^{257}$ thus contributing to the perpetuation of the image of children as passive human beings with only one goal in life to grow up and become adults. ${ }^{258}$

The perception of childhood as time of 'becomings' also explains the Committee's fixation with expanding the protection for children's development as a means to protect their 'full' development. For the Committee, it seems only natural to interpret the Convention's protection for children's development in such a broad manner. This narrow approach not only reflected in the care for the emotional, physical, social, mental, psychological, aspects of children's development, but also for the conception of development itself. The desire to provide as broad a protection to children's course of growth as possible has led the Committee, as it led the Convention's drafters, to mix the protection of 'development' with the protection of children's 'well-being' and 'fulfilling the potential' of children. The Committee confuses these three concepts together, although all three have different (with some potential overlaps) meanings. This approach creates a broad protection for a narrow

\footnotetext{
254 Alison Diduck, Law's Families (Lexis-Nexis, London 2003) 79.

255 UNCRC 'Concluding Observations: United Kingdom' (20 October 2008) UN Doc CRC/C/GBR/CO/4, paragraph 35 .

${ }^{256}$ With the exception of but stating the ensuring the right to participation is needed 'in order to empower children to their fullest development and dignity'. UNCRC 'Concluding Observations: Dominic Republic' (21 February 2000) UN Doc CRC/C/15/Add. 150, paragraph 25. Similar statement can be found in General Comment 12. UNCRC, 'General Comment 12', supra n. 17.

257 The right to participation. See UNCRC, 'General Comment 5', supra n. 1.

258 This conclusion also meets the interpretation of the right to development concluded from the drafting process of the Convection. See chapter two. The Committee has many failures with respect to the right to participation. See Aoife Nolan, 'The Child as a Democratic Citizen' (2010) 4 Public law 767, 782.
} 
concept of development that leaves no need to develop an understanding of the right to development itself.

Another difficulty in the Committee's jurisprudence is its usage of the right to development as one of the Convention's guiding principles; or, perhaps more aptly, the lack of its use as such. The right to non-discrimination, for example, is interwoven into the Committee's interpretation. It is evident that all of the Convention's rights should be implemented without discriminating against any group of children. Likewise, all of the Convention's rights should be implemented while enabling children to express their views. Unfortunately, thus far the Committee has failed to recognise the importance of this aim.

The question that should therefore be asked is, is there any real substance to the right to development? Perhaps, due to the Convention's aim to support children's course of growth, the Committee is right in subjugating the Convention to support as many domains of children's development as possible. Such a conclusion not only ignores the existence of this right as a distinct right, but also the potential it has for supporting this line of interpretation. While it is possible to perceive 'development' in 'the right to development' in psychosociological terms, and interpret the right accordingly, other options are available as well.

\section{Conclusion}

As with the Convention, the Committee's jurisprudence does not sufficiently distinguish between children's development and their right to development. The Committee provides broad protection for children's development, while it does not explicitly clarify what children's development means, and its jurisprudence lacks any coherent interpretation of the child's right to development. Derived from a range of psycho-sociological conceptions of 'development', the Committee's jurisprudence amounts to a detailed, but nevertheless biased, catalogue of how to raise a child while caring for her development.

The long and detailed nature of the catalogue creates the impression that it is also substantial. But the Committee finds it difficult to translate its desire to protect children as becoming human beings, and, therefore, their development, to the actual protection of their legal right to development.Despite its clear intentions, as expressed time and again over the years, the Committee's interpretation does not provide any holistic concept of the right to development, but rather constitutes, at most, a very detailed catalogue about the steps necessary to protect the elusive concept of 'children's development'. 
The committee is failing to accomplish what has been recently described by its former chairperson, Japp Doek, to be its "core activity' ${ }^{259}$ - to monitor the implementation of the Convention. After reviewing hundreds of States Parties' implementations reports, it is very disappointing that the Committee has yet to produce a coherent jurisprudence of one of the core components of the Convention.

Based on a series of in-depth interviews with members of the Committee and an analysis of the Committee's 'chain of monitoring', the next chapter continues the analysis of the Committee's work. More specifically, it focuses on member of the Committee's perspectives on their own jurisprudence, and their views about the feasibility to change.

259 Japp E. Doek, 'The CRC: Dynamics and Directions of Monitoring Its implementation' in Antonella Invernizzi and Jane Williams (eds) The Human Rights of Children (Ashgate Falmer, London 2011) 99-116, 99. 


\section{Chapter Four: The Perspective of Members of the UN Committee on the Rights of the Child on the Right to Development}

'I can tell you that the Committee doesn't know what to do with this right to development' (Member of the UN Committee on the Rights of the Child)

'In relation to article 6 and the right to development, I have to agree that we have neglected development' (Member of the UN Committee on the Rights of the Child)

\section{$\underline{\text { Introduction }}$}

This chapter asks two questions. First, why the UN Committee on the Rights of the Child's jurisprudence on the right to development does not amount to a coherent interpretation? Second, what changes are needed so the Committee will be able to fulfil its role as a monitoring body, and create such a coherent interpretation of the right to development of children? Answering these two questions, the chapter will illuminate theoretical and practical limitations that so far have prevented the realisation of the child's right to development.

The chapter is based on a series of in-depth interviews with members of the Committee, and on an analysis of the Committee's 'chain of monitoring'. The interviews provide the interviewees' explanations for the gap between the importance of the right to development on the declaratory level, and the Committee's jurisprudence in practice. The second issue the interviews address is the changes needed so the Committee will be able to articulate its own understanding of the child's right to development and thus, effectively monitor its implementation on the ground. The second source - the Committee's 'chain of monitoring' provides important complimentary perspective on the impact that the monitoring process itself has on the Committee's jurisprudence.

The chapter has three sections. The first section addresses the grounds for the Committee's unimpressive jurisprudence on the right to development. Four explanations can be drawn from the interviews: the right to development lacks conceptual clarity; States Parties provide insufficient information about the measures they took with respect to the child's right to development and, therefore, the Committee cannot monitor their actions; the Committee, as an institution, simply forgot that this right even exists; and the last explanation is a disciplinary gap concerning the understating of the term 'children's development' restricts 
the Committee from interpreting it. The second section analyses empirical evidence of the Committee's 'chain of monitoring', taking the year 2010 as a case study,in order to challenge two of those four claims. The section examines whether and how States Parties refer to the right to development in their periodic implementation reports, and the Committee's counter responses. Evidence indicates that the Committee takes a passive role, and that it is most likely to address the right to development only if a State Party mentions this issue. The last section turns back to the interviews with the members of the Committee, and asks what is next? This section focuses on the changes in the Committee's work, perceptions and modes of interpretation that are necessary for making a change in its interpretation of the right to development.

\section{$\underline{\text { Methodology }}$}

The chapter is based on two sources. The first source is a series of in-depth, semi-structured interviews ${ }^{1}$ with nine members of the Committee (one former member and eight current members). These nine people are part of the sixty-two people who served as members of the Committee since it was established in 1991, and until 31 December $2011^{2}$

One of the interviewees served at the Committee for eight years, two interviewees served for six years, three interviewees served for three years and three interviewees were at the beginning of their term, having served less than a year.Two of interviewees have served, or were serving, as the Committee's Chairpersons or vice-Chairpersons at the time of the interviews.

The interviews were held in June and September 2011 at Palais des Nations in Geneva, where the Committee holds its sessions. The interviews were conducted in English and lasted between half an hour and two hours. Six interviewees consented to have the interview recorded, while the other three preferred that only notes would be taken. Every interviewee received the interview's transcript or notes, and had the opportunity to make any comments or amendments. All comments received were accommodated. To ensure fluency of the

\footnotetext{
1 Alan Bryman, Social Research Methods (3 ${ }^{\text {rd }}$ edition, Oxford University Press, Oxford 2008) 191-214, 230251, 435-470; see also Herbert M. Kritzer, "'Research Is a Messy Business" - An Archeology of the Craft of Sociolegal research' in Simon Halliday and Patrick Schmidt (eds) Conducting Law and Society Research (Cambridge University Press, Cambridge 2009) 264-285.

2 According to the original Article 43(2) of the Convention, the Committee was composed from tem member. In 2002 the Article was amended and the number of members was increased to eighteen. UNGA Resolution 50/155 of 21 December 1995 (entered into force on 18 November 2002).
} 
interviews' texts, minor linguistic amendments were made. Though none of the interviewees have asked to remain anonymous, I have decided to use pseudonyms. I made this decision mainly because I do not seek to criticise (or compliment) any of them personally, but rather to focus on the institutional dimensions of their work. Unfortunately, the pseudonyms do not adequately reflect the identities and backgrounds of the interviewees, and might create an impression of lack of diversity. This is not the case.

An effort was made to diversifythe disciplines, countries of origin and professional backgrounds. Two of the nine interviewees are lawyers (Mark and Nick);two are diplomats with backgrounds in either humanities or law (Theresa and David) or in sociology and psychology (Cary);one is an early childhood expert (Brenda);one is a medical doctor (Donna); and two are economists who specialize in early childhood policy (Alicia and Grace). In terms of geographical background, one interviewee came from Africa, two from the middle east, one from the Gulf, three from Europe and two from the far east.

The second source is an analysis of the Committee's 'chain of monitoring', taking the year 2010 as a case study. According to the Committee's Reporting Guidelines, ${ }^{3}$ the "chain of monitoring' includes States Parties implementation reports, the Committee's follow up questions ('Issues of Concerns') and the twenty-three Concluding Observations that followed and were published in 2010 during the Committee's 53-55 sessions. The research excludes reports submitted by UN agencies and non-governmental organizations' shadow report, which are part of the 'chain of monitoring' as well. These reports were not part of my research as my focal point is the Committee.

\section{The Interviews - Between Lack of Awareness and Conceptual Challenges}

This section focuses on the reasons for the Committee's unsatisfactory jurisprudence on the right to development. If there was one issue that all the interviewees agreed upon, it was that a major gap exists between the Committee's rhetoric on the importance of protecting the child's right to development, and the Committee's jurisprudence on this right. The interviewees were unanimous in their opinion that thus far, the Committee's engagement with the right has produced insufficient results. The different reasons the interviewees gave can be divided into three categories. The first category includes committee members who see the

\footnotetext{
${ }^{3}$ UNCRC, 'General Guidelines Regarding the Forms and Content of Period Reports to be Submitted by States Parties Under Article 44(1)(b) of the Convention' (29 November 2005) CRC/C/58/Rev. 1.
} 
root cause in States Parties lack of reporting about the right to development. ${ }^{4}$ The second category of reasoning places the blame on the Committee itself, claiming that since it has consistently failed to engage with the right to development for a variety of reasons. The third category is what I term as 'the discipline gap'. Mentioned by two of the interviewees, they argue that lawyers do not sufficiently understand the term 'children's development', and therefore cannot adequately interpret it as a human right.

\section{States Parties Ignore the Right to Development}

This explanation situates the Committee as a passive actor in the monitoring process, and allocates the responsibility for the Committee's unsatisfactory jurisprudence on States Parties. The interviewees who held this position claimed that if an issue, like the right to development, is not being raised by a State Party, then the Committee cannot develop its own jurisprudence on that matter. Alicia, for example, claimed that 'development is not mentioned very often by States Parties', and therefore the Committee is bound to ignore it as well. However, as the second part of this chapter shows, even when States Parties ignore the right to development, the Committee does not address this omission, either by asking States Parties to address the right to development, or by flagging the lack of attention to this right in the Concluding Observation. Moreover, when the Committee wants to raise awareness to an issue that it deems important, it can take the initiative and write a General Comment about it. Thus far, the Committee chose not to do so with respect to the right to development.

The question that followed was why States Parties ignore the right to development. The answers given to this question can be divided into three. The first explanation was that States Parties 'do not know what development means', as Donna said, adding that 'sometimes States just do not understand what they need to do. But I think that the child's Convention is the easiest one to understand and to implement'. This is rather ironic comment, considering the Committee's own failure to articulate the meaning of this right. Nonetheless, David agrees with Donna, adding that 'the issue of the right to development still needs further clarification for States Parties'.At this point, it was only David who employed the term 'right to development', whilst the other interviewees kept using the term 'children's development'.

\footnotetext{
4 A similar claim is made with respect to the UN human rights treaties system in general. John Morijn, 'Reforming United Nations Human Rights Treaty Monitoring Reform' (2011) 29 Netherlands International Law Review 295, 303.
} 
The lack of distinction between these two terms persisted during most of the interviews with all of the interviewees.

A second explanation emphasised the impact of politics. Grace claims that States Parties' political considerations prevail over human rights and lead to a situation where children's development is ignored. Speaking in general terms, she claimed that 'the political situation in the state, the public opinion and education about it are the reasons for mentioning, or not mentioning, development directly.' These considerations lead some States Parties to try to evade their duty to respect children's development by challenging the Committee's mandate. She continues:

'When I ask states about the right to development, some of them answer my questions but some don't. They think that this question is not part of our mandate, but part of the Committee on Economic, Social and Cultural rights. But of course, it is within our mandate, because everything that relates to children is part of our mandate.'

Grace further suggested that beside the political manoeuvres to avoid the duty to respect and report about the right to development, States Parties may perceive children's development as an issue related to economic policy or socio-economic rights, rather than an issue of the individual's right to development, and consequently beyond the Committee's jurisdiction. She also implies that while the Committee views children's social welfare rights as an issue within its mandate, some countries do not share this view. Grace's comment conceals an argument that States Parties are being asked about children's development during the oral sessions. This suggestion was not supported in any of the sessions that I attended during this research. ${ }^{5}$ Not only the Committee's members did not raise the issue of the right to development, but even when the Committee reviewed the implementation of Article 6, the Chairperson stated time and again that the discussion is dedicated to 'Article 6' in abstract, or more often to 'Article 6 and the right to life', ignoring the right to survival and the right to development. Subsequently, the Concluding Observations that were published following these discussions did not refer to the right to development.

A third reason was the gap in expectation between the Committee and States Parties. David claimed that the Committee's failure to address the right to development over the years, which was fed by States Parties lack of reporting, has created vicious circle. Since States

\footnotetext{
${ }^{5}$ The Committee's $58^{\text {th }}$ session, held in September 2011.
} 
Parties 'depend on the issues that we [the Committee] have highlighted before', and due to lack of criticism of States Parties for not providing sufficient information about measures taken to promote the right, States Parties do not feel the need to address this right.

\section{The Committee Ignores the Right to Development}

The second line of explanations centres on the Committee, holding it responsible for not adequately engaging with the right to development. Different justifications were given to this failure, ranging from amnesia to problems in understanding the meaning of the right.

Brenda made the boldest statement, admitting that 'in relation to Article 6 and the right to development, I have to agree that we have really neglected development'. Grace added that the Committee did not adequately define the meaning of the right to development, due to practical and conceptual reasons.

'The reason that you cannot find a modern definition of the right to development in our work until this day, after twenty years of implementing the Convention, is because we are still struggling to make States Parties implement the basic principles of the Convention on the ground.'

Grace's suggestion that other rights are more important than the right to development contradicts the Convention and the Committee's own position on the subject. ${ }^{6}$ Nevertheless, this view may be an indication of the Committee's real priorities concerning the right to development vis-à-vis other rights. Alicia seems to agree with Grace's claim, but she has a different perspective. Alicia claimed that 'paying attention to the right to life and the right to survival is obvious, but the right to development is still debated'.

Another reason for the Committee's reluctance to directly engage with the right to development is, according to Mark, practicality.

'In our Concluding Observations, we have to be practical. This is not a place for making general comments, and we are not in a place to educate or to teach a lesson. We need to give practical suggestions on specific issues. We need to highlight the obstacles for implementing the Convention. However, in the introductory paragraph of the Concluding Observation, we do highlight general issues, such as development of the child. But in the specific paragraphs, we will deal with specific rights."

\footnotetext{
${ }^{6}$ The Convention's Preamble; See also UNCRC 'General Comment 5 - General Measures of Implementations of the Convention on the Rights of the Child' (27 November 2003) UN Doc CRC/GC/5/2003.
} 
On the one hand, Mark claimed that development is not a specific right but rather a 'general issue', which should be interpreted as such. On the other hand, at a later stage of the interview, Mark restated Alicia's claim, suggesting that 'although development is an integral part of Article 6, in the discussions we have had on this Article so far, we have focused on the right to life and the right to survival.' Brenda shared his views, adding that

'we always implemented only the first two components of Article 6. We were concerned with the right to life in relation to mortality rate, the death penalty, choosing the gender of a baby, etc., and also survival, but we did not discuss development.'

Brenda was also willing to admit that the Committee did not fulfil its role to substantiate Article 6 and the right to development.

'The right to development is one of the four guiding principles of the Convention, but we did not discuss it so far in an open forum such as "day of discussion" or in a General Comment. Since 2003, when I joined the Committee, we were planning to have a day of discussion or a general comment about the issues. It became evident for us that we did not pay enough attention to the four guiding principles, including the right to development.'

Nick agreed with some of Brenda's comments, saying that: 'I don't think that we have asked states to bring this data to us'. Mark has suggested looking at the Committee's jurisprudence from a different perspective, asking to distinguish between its operational roles in monitoring the implementation of the Convention, and its role as a commentator.

'In relation to General Comments - I have to say that I was not aware of the fact that we were not using development so far. The General Comment on Article 12 is a juridical one, while the others are more protective. The spirit of them is protective. In the juridical one, you will not find development, but in the General Comments about health or education you will find development. '

Mark's analysis is not very accurate. In practice, children's development is mentioned in number of General Comments, including General Comments 4 on adolescent health and development, General Comment 1 on the aims of education, and in General Comment 12 on children's participation. On the conceptual level, the distinction between judicial work and protection is not very clear. The protection of children's development applies equally to all 
the three domains that Mark mentioned: education, health and participation. While the first two are rather distinct domains in the child's life, the right to participation ought to be protected, according to Article 12 of the Convention, with regard to 'all matters affecting the child'. This sort of explanation is, to say the least, unsatisfying.

\section{The Discipline Gap}

The third explanation shifts the attention from the Committee or States Parties to the members of the Committee themselves. Though Brenda already suggested that 'the committee' as an institution has neglected the right to development, this line of reasoning is different. Cary has emphasised this point, arguing that there is a need to better comprehend the conception of 'development' in order to be able to analyse the right to development. It is interesting to note that only Cary and Brenda, neither of whois a lawyer, shared this issue. In Cary's words:

'I come from a sociology and developmental psychology background, and in my profession we have an idea what development is. And most of the disciplines, which are represented on the Committee, don't have an idea of (individual) development.'

Cary realises that those who come from other professional backgrounds might not share his understanding as a psychologist of the meaning of 'children's development'. Cary's claim is that different professional backgrounds influence the Committee members' perceptions of the right to development, the need to engage with it, its meaning and its relationship with children's development and other human rights. This is where what I call the 'the discipline gap' lies. Cary rightfully argued that a key explanation for this gap could be traced back to the Convention.

'I also think that the drafters of the Convention did not know precisely what development means. Nobody can deny that a child is a developing human being. So they said that somewhere we have to refer to child's development in the Convention. '

Cary pointed his finger at one of the main problems with the Convention already discussed in chapter two, namely the Convention's desire to protect children's development without clarifying what it actually means, or what is the significance of Article 6. Caryfurther claimed that while he served as a Committee member, he had tried to draw the attention of his 
colleagues to the right to development, but for number of reasons, those attempts failed.

'I can tell you that the Committee doesn't know what to do with this right to development. Sometimes, when we were writing a Concluding Observation, I told my colleagues that we better change the heading of the respective paragraphs and not call it "life and survival" because there is nothing about development in our recommendations. Usually it is all about survival, child mortality, and nothing about development and consequently we should not mention development in the heading...

'Did the Committee ever address such issues? No, I cannot remember such a discussion. I do not know whether there were any developmental psychologists on the committee before Brenda and myself were members. We both reminded the colleagues on the committee several times that we are neglecting the issue of development, and our colleagues agreed. But our time schedule is so tight that we did not find the time to have a thorough debate on this issue.

These observations concerning the oversight to refer to the right to development coincide with the findings of this research. The strains between disciplines are predominantly expressed between the lawyers and the non-lawyers. The lawyers, according to Cary, just do not understand the importance of development or its meaning. While Cary referred to the term 'right to development' time and again during the interview, when he turned to speak about psychology, the human rights rhetoric suddenly vanishedand he began using the term 'children's development' instead.

Brenda however claims thata different professional background is only a partial explanation for this gap.

'I understand development to have several meanings, which vary depending on the context. For those who are coming from a psychological background, development has a certain meaning. But for those who are coming from the international community, people from the UNDP for example, development has a different meaning. They hold a different conception of development. This gap might be the reason for neglecting this component of Article 6...I think that the confusion is still there. Until now, we were not truthful about the fact that there is confusion, and we never asked what does the right to development in Article 6 mean.'

This statement best summarises the Committee's approach to the right to development. As Brenda admits, the Committee simply never asked what Article 6 and the right to development mean. All the other reasons that focus the attention on the difficulty to understand the right to development, or on States Parties' failure to engage with this right 
seem minor. It is, after all, the Committee's role to monitor the implementation of the Convention. It is the Committee that needs to guide States Parties, and not the other way around.

The next section addresses the relationship between the Committee and States Parties, through analysing the Committee's 'chain of monitoring'.

\section{Analysing the Committee's 'Chain of Monitoring'}

The importance of the 'chain of monitoring' and its influence on the Committee's ability to fulfil its functions as a monitoring body became evident during this research. This section challenges two claims made during the interviews. First, the claim about States Parties' failure to report about the measures they took with respect to the right to development. Second, the claim concerning the Committee's active role with respect to the implementation of the right to development. This section takes 2010 'chain of monitoring' as a case study, and analyse the 23 Concluding Observations that the Committee issued that year, reviews the relevant States Parties' implementation reports, and the Committee's 'List of Issues'. I was looking to see how States Parties relate to the right to development in their reports, and how the Committee handles these reports. The aim is to understand where the monitoring process fails with respect to the right to development.

The findings shows that State Parties' implementation reports can be classified into two categories: indirect engagement with the child's right to development and no engagement with the child's right to development. In this sample of implementation reports, there was not even a single report that directly and explicitly referred to the child's right to development. The Committee's response to each of these two categories is similar: the Committee is passive. In general, and regardless whether a State Party relates to the child's right to development in its implementation report or not, the Committee will not ask any question about it in the 'List of Issues', nor will it highlight this omission in the Concluding Observations. 


\section{Indirect Engagementwith the Right to Development}

Most of the twenty-three implementation reports in the sample are included in this category. These reports do not explicitly mention the child's right to development. However, they do mention or refer to children's development when addressing other rights, and make different links between children's development and promoting children's rights. These links are made mostly with respect to the right to health, the right to adequate standard of living and the right to education. This pattern mirrors, and probably is a result of, the Committee's emphasis on the connection between promoting these rights and promoting children's development.

Spain's implementation report is a good example of an 'indirect engagement' type of report. In its report, Spain referred in greater detail to children's development on a number of occasions, including mentioning Article 6 as a source for obligations towards children's development. It further described new legislation thatsets prevention of damage to children's development as a guiding principle for public authorities, adding that governmental policies 'should be mainly aimed at the full development of their [children's] different personalities'. The report also mentions the need to support children's 'maximum' and 'proper' development with relation to education, health and children's standard of living. The right to development is not explicitly mentioned in this report. ${ }^{8}$ Another good example is Japan's implementation report. The section about Article 6 in its implementation report does not refer to the right to development or children's development, and focuses only on the right to life. Children's development is mentioned with relation to other aspects of the child's life, two of them being youth online activities and children's welfare. ${ }^{9}$

The implementation reports of El Salvador, Mongolia and Grenada are other examples. These reports do not include a section dedicated to the implementation of Article 6, but a widerange of children's developmental domains are referred to when reporting on the implementation of other rights. For example, El Salvador's report rapidly refers to the 'National Policy for the Full Development of Children and Adolescents ${ }^{10}$. It mostly emphasises health, education or media regulation. Children's 'psycho-motor development' is

\footnotetext{
7 UNCRC, 'Consideration of Reports Submitted by States Parties Under Article 44 of the Convention - Spain' (20 November 2009) UN Docs CRC/C/ESP/3-4 [30 May 2008], paragraph 58.

${ }^{8}$ Ibid.

9UNCRC, 'Consideration of Reports Submitted by States Parties Under Article 44 of the Convention - Japan' (25 September 2009) UN Docs CRC/C/JPN/3 [22 April 2008].

${ }^{10}$ UNCRC, 'Consideration of Reports Submitted by States Parties Under Article 44 of the Convention - El Salvador' (23 July 2009) UN Docs CRC/C/SLV/3-4, 7 [21 February 2008].
} 
mentioned with regard to tackling anaemia and nutrition during pregnancy. ${ }^{11}$ In Mongolia's implementation report, children's development is referred to when reporting on the expansion of the national medical insurance, the establishment of a national children's development plan, and various legislative amendments in the area of family law (parental responsibilities), health and education that were carried with the aim to protect and contribute to children's development. ${ }^{12}$ Grenada's implementation report elaborates on children's development when addressing Articles 28-29 of the Convention, stating that the national curriculum is aimed 'at promoting the spiritual, moral, cultural, intellectual and psychical development of students and preparing students for the opportunities, responsibilities and experience of adults' life'. ${ }^{13}$

Burkina Faso's implementation reportrepresents another version of an 'indirect engagement' type of report. Though the report includes a section titled 'The Right to Life, Survival and Development', it does not address tothe right to development itself. ${ }^{14}$ Throughout the rest of the report, children's development ismentioned with regard to the health and well-being of children, mainly in relation to improving public health services 'in the context of sustainable human development'. ${ }^{15}$ Children's 'intellectual' development is also mentioned in the context of the 'cultural excellence contest', which was held in the country. ${ }^{16}$ Furthermore, Burkina Faso claimed that one of the aims of its education system is to promote children's psychomotor, cognitive, social and emotional development. ${ }^{17}$

Belgium's report is an exception to this sort of reports. While the section dedicated to Article 6 focuses on the right to life, children's development is mentioned with regard to the implementation of other rights such as the right to education (student counselling centres were established in order to promote 'students' welfare and development', and activities that were established with the aim of promoting children's 'cultural development'); ${ }^{18}$ the right to play and to leisure ('broad range of initiatives devised by the youth organizations in Flanders

\footnotetext{
${ }^{11}$ Ibid, paragraph 36.

12 UNCRC, 'Consideration of Reports Submitted by States Parties Under Article 44 of the Convention Mongolia' (9 June 2009) UN Docs CRC/C/MNG/3-4 [31 March 2008].

13 UNCRC, 'Consideration of Reports Submitted by States Parties Under Article 44 of the Convention Grenada' (7 August 2009) UN Docs CRC/C/GRD/2 [26 May 2008].

14 UNCRC, 'Consideration of Reports Submitted by States Parties Under Article 44 of the Convention Burkina Faso' (30 March 2009) UN Docs CRC/C/BFA/3-4 [21 June 2008], paragraphs 25-26.

${ }^{15}$ Ibid, paragraph 50.

${ }^{16}$ Ibid, paragraph 84 .

${ }^{17}$ Ibid, paragraph 86.

${ }^{18}$ Ibid, paragraph 52.
} 
contribute to children's general development'); ${ }^{19}$ policy issues such as media regulation (A new domestic law classifies television content in order to protect 'minors against broadcasting likely to harm their physical, mental or moral development' $) ;^{20}$ and a smoking prevention campaign that includes the aim of promoting children's development. ${ }^{21}$ After presenting this long list of issues relating to children's development, the report mentions the right to development at its very end, under the section dedicated to 'difficulties and future objectives'. Belgium states that:

'The current trend in medicalization to make children "normal" to fit in with the model most convenient for adults (a good and clever child) must be called into question. Every child has the right to develop his or her personality, subject to respect for the rights of others. The competent governments will continue to ensure that measures in respect of children are taken in the light of their personal development and not exclusively for the benefit of adult society. ${ }^{22}$

This comment is interesting, not only because it explicitly mentions the right to development. Though it refers to the right of the child to develop her personality, it relates to it as a conditional right, subjecting it to respect of the rights of others. In light of Article 5 of the Convention, it states that realising the right to development should be conditioned according to the child's evolving capacities. This view will be further discussed in the next two chapters, but in the context of this chapter, this comment is important if only for referencing to the child's right to development.

These reports attest to the claim that States Parties rarely mention the right to development in their reports, or ignore the connection between children's rights and children's development. It is worth paying attention to another point, which is the different meanings given to children's development by different States Parties. These differences not only reflect division between disciplines with regard to the meaning of this concept, but also highlight the significance of politics and culture on interpreting human rights. Nonetheless, while States Parties mostly ignore the right to development, the question that still remains open is how the Committee react to this report.

\footnotetext{
${ }^{19}$ UNCRC, 'Consideration of Reports Submitted by States Parties Under Article 44 of the Convention Belgium' (4 December 2009) UN Docs CRC/C/BEL/3-4 [15 July 2008], paragraph 46.

${ }^{20} \mathrm{Ibid}$, paragraph 63.

${ }^{21}$ Ibid, paragraph 108.

${ }^{22} \mathrm{Ibid}$, paragraph 128.
} 
With the exception of Japan and El Salvador, the Committee responded to these reports with silence. No questions concerning the implementation of the child's right to development or other domains of development were asked, and States Parties' failure to address the right to development was not mentioned either. ${ }^{23}$ The Concluding Observations that followed also failed to engage with the issue of the right to development, though in most cases, take Angola and Belgium as examples, the Concluding Observations did refer to the other three guiding principles of the Convention. ${ }^{24}$ The Committee does not condemn States Parties for ignoring these issues. Thus, the Committee does not seize the opportunity to develop its jurisprudence on the right to development.

Having said that, the case of El Salvador is worth a brief consideration. The follow-up questions did not explicitly refer to children's development, and the questions about the implementation of Article 6 touched upon issues relating to the right to life. ${ }^{25}$ Nevertheless, the right to development was mentioned in the Concluding Observation when the Committee addressed the right to adequate standard of living. ${ }^{26}$

\section{Ignoring the Right to Development}

This category includes States Parties' implementation reports that fail entirely to refer to the right to development or children's development. Sudan's implementation report is a good example for this kind of reports. In its report, Sudan declared that the State's constitution is 'in line' with the need to protect children's 'survival and development', and a reference was made to a section in the 'national programmes on survival and development' relating to children's health. ${ }^{27}$ But under what may be seen as a promising headline, the report described Sudan's efforts to reduce infant, child and mother mortality rate, its legislation concerning

\footnotetext{
${ }^{23}$ UNCRC, 'List of Issues Concerning Additional and Updated Information Related to the Consideration of the Combined Second to Forth Periodic Reports of Angola' (18 June 2010) UN Docs CRC/C/AGO/Q/2-4; UNCRC, 'List of Issues Related to the Consideration the Third and Forth Periodic Reports of Belgium' (8 March 2010) UN Docs CRC/C/BLG/Q/3-4; UNCRC, 'List of Issues Related to the Consideration the Third Periodic Reports of Japan' (5 February 2010) UN Docs CRC/C/JPN/Q/3.

24 UNCRC, 'Concluding Observations - Angola' (11 October 2010), UN Docs CRC/C/AGO/CO/2-4, 6-7; UNCRC, 'Concluding Observations - Belgium' (18 June 2010), UN Docs CRC/C/BEL/CO/3-4; UNCRC, 'Concluding Observations: Japan' (20 June 2010), UN Docs CRC/C/JPN/CO/3.

25 UNCRC, 'List of Issues Related to the Consideration the Third and Fourth Report of El Salvador (2 November 2009) UN Docs CRC/C/SLV/Q/3-4.

${ }^{26}$ UNCRC, 'Concluding Observations: El Salvador' (17 February 2010) UN Docs CRC/C/SLV/CO/3-4.

27 UNCRC, 'Consideration of Reports Submitted by States Parties Under Article 44 of the Convention - Sudan' (24 February 2010) UN Docs CRC/C/SDN/3-4 [27 June 2008], paragraph 19.
} 
children's right to immunization, and increasing measures taken to ensure food safety. ${ }^{28}$ The child's right to development is not mentioned with respect to Article 6 or any of these programmes. Without undermining the importance of these steps, and though the report uses the term 'children's development' number of times, it seems that these steps can be classified as efforts to promote children's right to life and right to survival, and not their right to development. Although, as I argued before, ${ }^{29}$ the border-lines between the three rights is sometimes blurred, it is rather easy to make this distinction in this case.

The Committee's response to this report did not include any request for additional information about the right to development. ${ }^{30}$ This right was also not mentioned in the Concluding Observations. ${ }^{31}$ Children's development, however, was mentioned with regard to early childhood development programmes and adolescent health, ${ }^{32}$ and the right to an adequate standard of living. ${ }^{33}$

\section{Conclusion}

In light of this evidence, the question of who is responsible for the lack of engagement with the child's right to development - States Parties or the Committee - seems as a question of the chicken or the egg. What is evident here is that a key reason for the Committee's failure to monitor the implementation of this right is the Committee's own approach. The Committee's systematic disregard of the right feeds into and perpetuates the on-going lack of attention given to it. The Committee has the responsibility to scrutinise States Parties when they fail to address the right. States Parties' role should not be undermined, but their lack of compliance is not a reason for neglecting the right to development.

The last part of this chapter continues with the interviews, and outlines how the Committee's members understand the right to development. Despite the Committee's failure to monitor the implementation of this right, some of its members have a relatively developed understanding of this right.

\footnotetext{
${ }^{28}$ Ibid, paragraph 33-57.

${ }^{29}$ See chapter two.

${ }^{30}$ Ibid.

${ }^{31}$ UNCRC, 'Concluding Observations: Sudan' (1 October 2010) UN Docs CRC/C/SDN/CO/3-4.

${ }^{32}$ Ibid, paragraphs 53-54.

${ }^{33}$ Ibid, paragraphs 60-63.
} 


\section{How The Committee Should Approach the Right to Development?}

The first section of this chapter demonstrated that the common view among members of the Committee is that the right to development is an important right, which in light of the Committee's record requires some more attention. This section asks for their opinions about the measures ought to be taken in order to change the Committee's engagement with this right.

The section begins with an introduction of the interviewees' general perception of children's development and right to development. It continues by presenting the different opinions of the Committee members about the future of the right to development. The section includes relatively long quotations, in order to provide as comprehensive and accurate account as possible of the Committee members' views.

In general terms, the main differences between the Committee members' suggestions lie with their profession. The gaps between different disciplines, which were previously described as a source of problems, were in this point predominantly seen as a source of strength, because it provides some useful insight about the potential meaning of 'children's development' and 'right to development'. However, all interviewees, except for one, were primarily concerned by their own professional vocabulary. Each of the suggested interpretationsderives from the ways in which every discipline conceptualises children, childhood and children's development. Therefore, while the lawyers emphasised the general significance they see in protecting the right to development (and the connection between this right and other rights of the Convention), none of them were able to articulate the meaning of 'development' and therefore of 'the right to development'. Those members of the Committee with a professional background in psychology, education or social welfare were much more comfortable with speaking about 'development' and 'children's development', while struggling to articulate these concepts in human rights terms.

\section{Bridging the Discipline Gap}

Today, the Committee inexplicitly employs developmental psychology as its underline narrative when referring to children's development. In doing so, the Committee ignores the diverse interpretation of this term at the discipline of developmental psychology itself, let alone the meaning of this term in other disciplines like pedagogy. Therefore, there is a need to raise awareness to the different options available to interpret the meaning of the term 
'children's development'. And as Cary pointed out, adopting any interpretation of 'development' inherently includes normative decisions.

'I think that one of the essential features of children is that they develop. Many people think that speaking of development means that developmental psychologists indicate at which age a child has developed which competence to which degree. In fact, this is not the main objective of this discipline, since the progress in developing capacities varies remarkably. It is much more interesting for developmental psychologists to better understand on which factors the development of children is depending. ‘

Cary has no doubts about the meaning of childhood and the meaning of development that follows it. For Cary, the main aim of children is to grow up, and the Convention in general, and Article 6 in particular, should be interpreted to support this goal. What needs to be decided is what constitutes this process of 'development'. According to this approach, Article 6 should be interpreted in a way that accommodates a wide range of developmental factors.

'You need article 6 as an umbrella principle, so you keep it in mind when the implementation of other articles of the Convention is at stake. You have to know that you need to reflect on article 6, you need to explain why any step supports the development of the child better than any other step. And for doing so, you need to know what development means and under which conditions development of children flourishes.'

This approach reflects the understanding of Article 6 as an interpretation tool, rather than as an article that protects a concrete and distinct human right of children, called the right to development.

'Developmental psychologists believe that development will proceed if what they call 'normal living conditions of children' are given. They believe in the spontaneous activity of the child, which will find in a 'normal' family context what she/he needs for development. So if we care for child's protection, we do all for development what has to be done. But meanwhile, we think that development is based on the interaction of the child and the social and the material context of the child. And we can point certain conditions that must be guaranteed so development will be able to take place. And then we come to the relationships that the child needs, we come to a standard of living that is necessary for development, you come to more stimulation, to motivations and then you move to the field, where also lawyers can understand and pay attention to conditions, which have to be guaranteed. This is difficult. In order to really implement the second half of article 6, lawyers will need an idea of circumstances, of opportunities, of factors, which influence development. Such a list can be provided by science. 
Like other developmental psychologists, Cary is convinced that he knows what children's development means, and what is required in order to enable the child to grow up in a healthy manner. It is therefore only natural to him to advise legal scholars to learn from psychologists what children's development means and what factors influence it. This perspective takes the view that only then lawyers become fully equipped to interpret Article 6 in a way that protects and promotes the 'true' meaning of children's development.

This approach is far from new. It follows traditional conceptions of childhood and children's rights, claiming that the role of society is to protect children's socio-psychological development. It utilizes law (international human rights law in this case) to fulfil the social aspiration of facilitating children's growth and transformation into 'full' or 'healthy' adults.

\section{Between a Distinct Right and a Guiding Principle}

David supports Cary's views, reaffirming that that for him also Article 6 does not stand as a distinct right of the child.

'you cannot isolate the development of the child from the actual tools of how to develop a child. The question is how you approach Article 6. I don't think that Article 6 can be implemented in isolation from other Articles, because they all should be taken as one unit. The purpose is to protect children and to provide them with their rights. And if you do so, you develop the child in an appropriate manner.'

This method of interpretation suggests adopting the protection for children's development as the prominent guiding principle of the Convention and, to some extent, subjugating the Convention to this principle. This approach is much different than the one expressed in General Comment 5, which specified four guiding principles of the Convention. Arguably, this does not differ substantially from the Committee's practice today, thought it is much narrower. This approach actively rejects the possibility of developing a distinct meaning for the right to development.

Theresa also thinks that the child's right to development should be understood as an inclusive concept. However, in order to protect children's development, she thinks that there is a need to realise that 'education, health and all the other provisions are complementary to each other. We cannot look at them separately.' Theresa's views are in line with the Committee's current 
jurisprudence, not only because she claims that promoting children's development requires realising other right, but also because she does not perceive Article 6 as providing standalone protection for a right to development.

Grace shares the view that sees the right to development as an integrated concept. Using the example of the right to health, Grace explains how all the Convention's rights are interrelated to support children's development.

'Now we are planning to make a General Comment on Article 24, where we will make the connection between health and development...But health is not everything, because when we are speaking about the right to health and the right to be heard, it means that we also speak about development. In order that children will be able to participate, you need to work hard and to develop them. When we are speaking about education, when we are speaking about leisure, when we are speaking about non-discrimination, and when we speak about every right in the Convention - they are all related and should be bound to development.'

This approach provides no distinct meaning for Article 6, and arguably makes the article meaningless. This interpretation further leads to a conclusion that children's development is sufficiently protected under the Convention, and that Article 6 has no added value other than as an inspiration or a guiding principle. None of the interviewees related to the potential contribution that the right to development could have in the promotion and protection of children's development when articulating it as a distinct human right.

Against this approach, Mark and Donna suggested understanding the right to development as an overall concept, and not as a summary of the protection of other rights of the child. The way in which Mark, a lawyer by training, understands the right to development supports Cary's claim about the need to bridge the gap between disciplines. According to Mark, although 'development is the objective of all the rights of the Convention', there is more substance to the right.

'It [the Convention] allows reaching the autonomous development of the child, it allows to promote children's rights. With regard to all of the rights, we need to promote development. When you look at education, standard of living or any other rights, you ought to think whether their implementation facilitates children's development...Development is not an isolated concept, but a parameter in a list.

'Article 6 has an added value. It is a general principle, and when we examine a state's report, when we look at each right, we also ask how a specific policy or legal provision impacts children's development. All four guiding principles are in our minds when we examine each right. This is 
why without Article 6 it would have been difficult to speak about development with relation to some of the rights, unless it was mentioned explicitly.'

This approach perceives the protection of children's development as an aim of the Convention (or 'The' aim of the Convention). While it does not ascribe a distinct meaning to Article 6 and the right to development, it does assign an added value to the Article. Mark recognises that without Article 6, subjugating most of the Convention's rights to the protection of children's development would not have been possible. On a different level, this approach exemplifies the extent to which the perception that children's development ought to be protected, is embedded in the Committee's members views.

Donna, a medical doctor who specialises in public health, suggests employing the concept of 'holistic' development, which is probably the most common description used to describe children's development, in interpreting Article 6. According to Donna,

'Article 6 must be looked at from a holistic angle. This is the difference, that children have the right to development. You cannot say - let the child be born and then let him grow or not...'

All of these views share some similarities. Predominantly, they all leave the right to development at the margin. They all articulate the protection of children's development as the aim of the Convention, ascribing Article 6 with the role of a guiding principle. Like their predecessors at the Committee, as well as the Convention's drafters, they all were satisfied with the current interpretation of 'children's development'. The only point about the meaning of development that was often mentioned was the question, or more accurately the tension, between universalism and cultural relativism. Some concerns were raised with regard to the question of whether children's development is a universal concept with a universal meaning, or whether it should be interpreted in a contextually sensitive manner. ${ }^{34}$

\section{What Does 'Children's Development' Mean?}

Two approaches concerning children's development prevailed during the interviews. The first approach emphasised the physical similarity between children, which in turn dictates a similarity in the process of development. The second approach argued that a distinction

\footnotetext{
34 On universalism, cultural relativism and pluralism in the context of children's rights see Michael Freeman, 'The Morality of Cultural Pluralism' (1995) 3 International Journal of Children's Rights 1.
} 
between different kinds of children's development ought to be drawn on the basis of their emotional needs, their family, society and the impact of the latter two on the child's development, and was less concerned with biology. Nick's approach best represents this line of argument, as he claimed that while physical development among children is identical, their moral development diverges in different cultural and social contexts.

'The right to development has an intrinsic nature to this biological human being that is called a child. The child should develop, and development has so many ingredients. It relates to the holistic nature of the Convention. For example, I would like to see [in States Parties' reports] references to the right to play, because a child without play will not develop. I would like to see references to development when addressing the right to health, because if there is no health provision then the child will not develop. I would expect to see a good family atmosphere, because the child cannot develop outside the family...The health and physical development of the child is universal. But the social or moral development could vary by circumstance...'

Though Nick does not use human rights terms, most of his examples can be formulated as Convention's rights.

The Committee implements somewhat linear attitude that links certain activities to specific domains of development. Donna employs her professional vocabulary to explain the influence of activities and social contexts on children's development.

'The point about development of children is that it is very age specific. The rate of development changes and the needs to develop in terms of fulfilling the child's full potential and capacity varies according to the scale of development.

'Development is based on your five senses. It is touch, sight, smell, sound and taste. This is how the child develop. The newborn child cannot talk, but his senses should be stimulated and this changes during his life. Later on, there are other stimulations for development. For example, education is stimulation - music and sports activities are related to development. My interpretation is that development is very age specific, you cannot have the same set of criteria for development when the child is a new born and when the child is one year old or at other critical moments in the child's life cycle.'

Donna makes an important observation concerning how the Convention should be interpreted. Shifting between the individual and the collective, this approach derives from the view that the physical development of children is a universal process, which requires a 
certain set of stimulations. These stimulations, she argues, will have the optimal impact on children's development only if they are implemented in a child-centred manner. While Donna also does not use human rights terminology, her argument can be articulated in this language as well. Namely, in order to promote children's development, their rights to education, play and leisure should be realised on the basis of the evolving capacities principles. This approach might also imply the need to have a right to a significant other, and to the stimulation of senses. The latter two are not recognised rights under the Convention or by international human rights law in general, but they can be read into the right to development. Nevertheless, this approach assumes a certain understanding of development and therefore preserves itself, since it takes the child's status of development ('age specific') as a parameter to determine what the necessary stimulations for her further development are.

The second approach, best represented by Grace, does not focus on the child's physical characteristics, and takes a more communitarian approach. Grace's approach is dialectic, as she is mostly concern with the relationship between the child's development and social conditions, between social conditions and the freedom of other members of the family and subsequently, the impact these freedoms will have on children. ${ }^{35}$

'Development is not only related to material life, but also to values, traditions and social life. For example, discrimination and development when you plan how you can free girls from discrimination, you are helping the development of the entire family. Because then the mother will feel free, and she will be able to work, to study, to travel and more. And it all leads to development, and these factors are not the same in every country. There are also differences within states, differences within regions within a state. And governments should be aware of these differences and put their efforts into the most needed areas. '

Grace is the only interviewee who mentioned the political science concept of 'development'. She departed from the psycho-social discourse and focused on the development of society and social mobilization. According to this approach, development should help remove social barriers that in turn will generate 'development'.

These two approaches provide rather clear understandings of 'development', but their relevance, if any, to the right to development requires further clarification. There is still a need to ask whether the right to development can be interpreted as having a meaning distinct from the concept of 'development', and if so, how. As David articulated that question, we should ask 'how you develop a child, what are the criteria [for development]?' Indeed, David

\footnotetext{
35 The relationship between development and freedom will be discussed in the next chapter.
} 
uses the term 'right to development' but only as a figure of speech, while the content of his statement refers only to 'development'.

'The right to development is a huge thing, because everything and anything is in it. Everything that concerns the child is part of the right to development...It has to do with everything that is related to the child and with anyone who is related to the child - governments, parents and NGO's. They all have a role to play in the development of the child...

'How do you develop a child, what are the criteria, from birth, to the age of 18 years old? From the moment the child is born, you need good health care for him or her and for the mother as well. Then you reach the stage when the child starts to understand things. It raises the issue of pre-primary education. And above all, the child's family environment is important in these early stages. Then you move on to continue educating, to health and family unity.

It seems that David is keen to interpret the Convention in a way that provides everything needed for children to develop, taking the right to development as a useful instrument that can fulfil this aim in two ways. It brings us back to the question whether the right to development is a distinct right or a guiding principle only. The right to development can provide 'an umbrella principle' for the numerated and unnumerated rights in the Convention that have the potential to impact children's development. The right to development can also create obligations for different actors (parents, society, state and the international community) to ensure protection of children's development. Like others, David comprehends the right to development as an interpretive tool more than a substantive human right.

\section{What is Next?}

Theresa is the one that had the most practical suggestion about the steps that the Committee should take to change its attitude towards Article 6. She suggested that the first step should be holding States Parties accountable for violating Article 6.

'When there is no accountability of states, when states cannot do assessment and evaluations -it is also a violation. We see a major role to accomplish the right to development and this is why there is a need for a monitoring mechanism.'

An apparent response to this statement will be to ask why the Committee did not execute its power, and duty, as a monitoring body? However, as obvious and simple as this suggestion 
might be, it can only be implemented once the Committee develops its understanding of the right. Only then the Committee will be able to expect States Parties to follow it, and to implement the Convention accordingly. Donna asked to meet the challenge of developing monitoring tools by suggesting to create indicators of implementation.

'We need to develop indicators to understand the meaning of the right to development, so we will also be able to implement it...You need to decide about development's indicators. All human beings share the same genetic code, except for chromosomes $\mathrm{X}$ for women and $\mathrm{Y}$ men and a number of genes. The human potential for development, in the biological sense, does not vary. But what varies is the family, the culture, the social conditions poverty, living in a village or a city, etc.

These kinds of indicators already exist, for example UNICEF's State of the World Children or the UN Development Agency Human Development Report, and they will be discussed in the next chapter. At this point there is a need to say, that in order for the Committee to be able to develop indicators or employ those already in existence, it first needs to develop its understanding of the meaning of the right to development. The creation of indicators should come after.

Alicia suggested a more modest step as a first measure for changing the Committee's approach, one that can be implemented rather more easily. She suggested requiring States Parties to take children's development into account when making long-term policy plans. According to Alicia:

'States' approaches are not concerned with the individual child, but rather with the future of the country. But there is a need to balance the individual needs and the collective ones. Take, for example, the right to play. If you take it seriously and invest money in it, it contributes to children's development and in the end it contributes to the economy. But opening schools for after-school activity, to provide music or sports lesson, or summer camps, costs money. And I always ask state's representatives if they consider doing these things, as they are the best youth crime prevention measures as well. It is simple cost analysis, but the problem is that any government that will invest this money now, will not be in power to see the fruits of its policy. This is why they are not doing so. There is no long term policy for children's development....If we take the Convention seriously, than there is a need to talk about children's long term development, regardless of other interests. Children are the rights holders. "

Nonetheless, Alicia is aware of the fact that States Parties would rather not bind themselves with this kind of commitment. 
'I am not naive anymore, and I cannot make this kind of argument with states' representatives. It is not enough. Policy makers ask for more rational reasons for investing in children. Policy makers say - we are not in a position to take care of children's development. But if they don't take into consideration the rights of every child, you will end up with no citizens or tax paying people. This is the most depressing thing for me, because even the rational, economical arguments, arguments from political perspectives, do not drive them for action.'

This observation is worrying. It implies that Alicia, an experienced member of the Committee, thinks that States Parties pay nothing more than lip service to the care of children's development, but in fact do not want to make a change in children's lives. Even more alarming is her observation that this pattern will not change.

Cary shares Alicia's view, saying that the Committee should ask States Parties to take into consideration the impact that its policies have on children's development.

'The committee urges governments to make sure that a judicial or administrative process, in which the best interests of the child is taken into account of, is documented, so that a child or her/his representative may ask for redress and revision if the outcome does not satisfy the expectations of the child. The committee should ask for the same transparent proceedings when the development of the child is affected by decisions of adults or institutions.

Maybe the most useful suggestion was Cary's advice to take it one step at a time, focusing on issues that everyone agrees upon.

'We need to develop article 6 by stating step by step what the essential things are. Maybe, we start with one component on which the child rights experts and the developmental research community agree. Perhaps it is the mother (primary caretaker)-child relationship, which has to be protected in all decisions and measures, as this relationship is so crucial for the child's development (parental leave in the first months or year). One of the first steps should also be the availability of early care institutions for groups of children who do not have a reliable caregiver at home. Or facilities for the promotion of the evolving capacities should be guaranteed. Another specification of this right could be the establishment of awareness-raising campaigns informing parents about the remarkable development of children's cognitive, social and emotional capacities in the early years and what they should to do so that these "windows of development" are not missed and are used. Maybe it is children's play opportunities (not only indoor; planning of the communities is needed). Other things may be added later. Some of these issues are addressed by the committee, but usually with reference to other articles (parental responsibility, article 18, or right to play, article 31' 
It will be appropriate to end this section with the most ambitious suggestions of all. Alicia, who formally expressed some despair from States Parties' unwillingness to care for the child's right to development, suggests creating a new mechanism in every Member State.

'In each state, a holistic mechanism for children's human rights is required. It requires an inter-sectorial cooperation that will work for the children's development and will harmonize all the different treaties. Countries need to assemble a committee of experts that will build a complex system for the implementation of all the treaties, and that implementation will be an organic part of human rights protection. Then they will also be in a better position to report. It will drive the government less crazy.

The Committee can implement most of these measures easily, immediately and with no added cost. It requires awareness and will.

\section{Conclusion}

The chapter examined the institutional and conceptual reasons that can explain the UN Committee on the Rights of the Child's jurisprudence concerning the right to development, as the members of the Committee themselves sees it. The chapter also asked for the opinions of members of the Committee about the steps the Committee should take, in order to further engage with the child's right to development. Seven main conclusions can be drawn from the interviews and the analysis of the Committee's 'chain of monitoring'.

First, the Committee members agree that it is immensely important to protect and promote the right to development. Second, thus far the Committee has not provided a satisfactory interpretation of this right, and therefore has not fulfilled one of its primarily roles as a monitoring body. Third, the Committee's jurisprudence about the right to development should be further developed. Fourth, in order to change the current jurisprudence about the right to development, the Committee needs to be active by asking States Parties to provide more information about the measures taken to comply with their obligations under Article 6. Fifth, the Committee does not actively monitor the implementation of the Convention's right to development. Whether a State Party relates to the right to development or not in its implementation reports, the Committee will most probably not ask for more information, or condemn the State Party for neglecting. Sixth, the Committee's members share the 'human 
becomings' conception of childhood, overlooking the child as a 'human being'. This in turn dictates and limits the scope of their interpretations of the right to development, and perpetuates of the lack of sufficient attention to the issue of agency. Seventh, and probably most important, there is a need to articulate the meaning of 'children's development' before plugging the gap between disciplines and surely before addressing the meaning of 'the child's right to development'.

The interviews demonstrate the problem to distinguish between the concept of 'children's development' and 'the right to development'. Regardless of whether the interviewees were asked about 'children's development' or 'the right to development', most of them employed the term 'children's development' and ignored the legalistic, human rights perspective of the question. Even when asked specifically about the right to development, most of the interviewees replied using the term 'children's development'. It was only the lawyers who were comfortable to address the child's right to development, but they struggled to articulate the meaning of this right. Lack of sufficient understanding of what 'children's development' stands for is, I argue, the reason for this difficulty.

The common perception of childhood that the interviewees hold is, without a doubt, the 'human becomings' perception. Time and again during the interviews it was argued that the main characteristic of children is to develop and to grow up. The perception of children as 'human being' was neither mentioned nor utilized as a concept for analysis. For this reason, the child's right to participation was mentioned only once at the interviews, as a relevant right to the process of realizing children's development and the right to development.

The next chapter tackles three of the main shortcomings of the current interpretation of the child's right to development, as identified thus far. Namely, the narrow conception of 'children's development' that derives from a psychological perspective, lack of recognition of children's agency and difficulties in concretising the right.Using comparative analysis, the next chapter analyses the potential meanings of 'development' and the 'right to development' according to the right to development in 'general' international law and the Capability Approach, and their potential relevance to the interpretation of the child's right to development. The chapter asks how such definitions can be implemented and measured. 


\section{Chapter Five: Comparative Analysis of Human and Children's}

\section{'Development'}

'Giving temporary freedom to a child does not always mean that the child will have freedom in future, and similarly, restricting the temporary freedom of a child may well expend the freedom that the child will have in the future. We, therefore, have to consider the freedom for a child in a lifelong perspective ${ }^{1}$

\section{$\underline{\text { Introduction }}$}

This chapter addresses three issues that are vital for the analysis of the child's right to development. The first is the meaning of the term 'children's development', the second is the lack of respect to children's agency when discussing the issue of promoting children's development, and the third is the challenge of concretising the term 'children's development' and articulating it in human rights terms.

The chapter has three sections. The first section analyses the right to development as protected in 'general' international law, ${ }^{2}$ presenting the conceptualisation of 'human development' under this legal regime. I suggest adopting key elements of it, including the distinction between the protection of the process of development and its outcome, and the respect for people's agency, when analysing the child's right to development. The second section studies the Capability Approach, presenting the concept of 'development as freedom', and the significance of agency and capabilities to the realisation of 'human development'. I suggest that children, as adults, should be conceived as entitled to develop in the Capability Approach's sense of the word. I discuss the feasibility to adapt the Capability Approach into the legal analysis of the child's right to development, and the compatibility of basic capabilities lists to children. The third section focuses on the Child Indicator Movement's conceptualising and measuring children's development and well-being. I discuses the ways in which 'children's development' is perceived and quantified, and ask whether these ideas can be framed in children's human rights terms.

\footnotetext{
${ }^{1}$ Madoka Saito, 'Amartya Sen's Capability Approach to Education: A Critical Exploration' (2003) 37 Journal of Philosophy of Education 17, 26.

${ }^{2}$ I use the term 'general' international human rights law to refer to human rights instruments such as the Universal Declaration on Human Rights or the 1966 Covenants, which are not group specific (unlike the UNCRC or CEDAW). In this chapter, and unless mentioned otherwise, whenever the term 'the right to development' is mentioned, it refers to the 'general' right to development and not to the child's right to development.
} 
The comparison between legal and non-legal regimes is carried out with the necessary caution and awareness of its limitations. With respect to the 'general' right to development, although this right shares the same title as the child's right to development, these two rights were created against different backgrounds, and with different images of their potential right holders (i.e adults and children). Children, as discussed later, were not recognised as rights holders of this 'general' right to development. Therefore, the comparative analysis accounts for the differences between these two legal regimes. A different caution is required when analysing the potential usage of the Capability Approach in the interpretation of the children's legal right to development, primarily because of the conceptual gaps between moral theories and a legal frameworks. ${ }^{3}$ This chapter, as well as the next one, takes these limitations into considerations.

The general right to development and the Capability Approach were created, to different extent, as responses to traditional political conceptions of 'development', which envisaged 'development' in terms of poverty elimination and bringing prosperity to the 'underdeveloped' world. ${ }^{4}$ Based on theories of economic liberalism, 'development' was conceived as synonymous with increase in Gross National Product per capita, advancing the approach that economic growth will trickle downand improve the economic conditions of all segments of the population. 'Development' was the corner stone of Western international aid programmes since the end of the Second World War, channelling billions of US Dollars to 'underdeveloped' countries. ${ }^{6}$ It was criticised for focusing on systems rather than people, perceiving the latter as means rather than ends. Feminist critique suggested that this theory was also gender biased, since it ignores women's role in society in general, and in economy in particular. ${ }^{7}$ More radical approaches claimed that 'development' and 'aid' constitute new forms of imperialism and colonialism. ${ }^{8}$

\footnotetext{
${ }^{3}$ On comparative analysis between legal instruments and other disciplines see Alan Watson, 'Comparative Law and Legal Change' (1978) 37 Cambridge Law Journal 313; Otto Kahn-Freund, 'On Uses and Misuses of Comparative Law' (1974) 37 Modern Law Review 1; Pierre Legrand, 'The Impossibility of 'Legal Transplants' (1997) 4 Maastricht Journal of European and Comparative Law 111; Rodolfo Sacco, 'Legal Formants: A Dynamic Approach to Comparative Law' (1991)39 American Journal of Comparative Law 1. Compare to David Kennedy, 'New Approaches to Comparative Law: Comparativism and International Governance' (1997) 2 Utah Law Review 545.

4 As described by Harry Truman, the president of the United States, in his inaugural address on January $20^{\text {th }}$, 1949.

${ }^{5}$ William A. Lewis, The Theory of Economic Growth (Routledge, London 2007. Original published in 1950) 910, 420-421.

6 David Hulme and Mark Turner, Sociology and Development (Harvester Wheatsheaf, New York 1990) 3-5; Ameda Obiora, 'Beyond the Rhetoric of a Right to Development' (1996) 18 Law \& Policy 355, 361.

7 The first feminist critique on development was published in 1970 by Ester Boserup. See Ester Boserup, Women's Role in Economic Development (Earthscan, Revised Edition 2007. Originally published in 1970); Also
} 


\section{The Right to Development in 'General' International Human Rights Law}

This section analyses the right to development in 'general' international law. It starts by briefly introducing the process by which the right to development was created, and then it moves on to focus on four issues: the meaning of the term 'development'; the distinction between protecting the process of development and protecting its outcome; the respect for people's agency and right to participation as an integral part of realising their right to development; and the differences between a collective and an individual right to development.

\section{The Creation of the Right to Development}

The suggestion to create a right to development in international human rights law was first introduced in 1972 in a speech given by Keba M'baya, the former vice president of the International Court of Justice. ${ }^{9}$ This innovative idea was born in light of an 'on-going experience of decolonialization, ${ }^{, 10}$ in Africa and other parts of the world, and the recognition of 'third world' legal scholars that existing human rights instruments, mainly the two 1966 Covenants, did not provide the necessary normative grounds to support collective rights, ${ }^{11}$ especially the right to self-determination. Another reason was that professionals who worked in international aid programmes (which where part of international development programmes), felt that grounding their work on the good will of governments was far from sufficient, and that a legal structure would solidify their efforts. ${ }^{12}$

see Jane S. Jaquette and Kathleen Staudt, 'Women, Gender and Development' in Jane S. Jaquette and Gale Summerfiled (eds), Women and Gender Equality in Development Theory and Practice (Duke University Press, Durham and London 2006) 17-52; Naila Kabber, Reserved Realities - Gender Hierarchies in Development Thought (Verso, London 1994) 76-77; Janet Mason, Gender and Development ( $2^{\text {nd }}$ edition, Routledge, London 2011) 11; Cecile Jackson, 'Rescue Gender from the Poverty Trap' in Cecile Jackson and Ruth Person (eds), Feminist Vision of Development - Gender Analysis and Policy (Routledge, London 1998) 39-64, 43-36.

${ }^{8}$ Arturo Escobar, Encountering Development (Princeton University Press, Princeton 1995); See also Uma Kothari who describes the transition from colonial to development administration. Uma Kothari, 'From Colonial Administration to Development Studies: A Post-Colonial Critique on the History of Development Studies', in Uma Kothari (ed) A Radical History of Development Studies (Zed Books, New York 2005) 47-66; William Easterly, The White Man's Burden (Oxford University Press, Oxford 2006); See also Cheryl McEwan, Postcolonialism and Development (Routledge, New York 2009); Ivan D. Illich, Celebration of Awareness (Calder\&Boyars, London 1969).

9 Arjun Sengupta, 'Realizing the Right to Development' (2000) 31 Development and Change 553, 555; Peter Uvin, Human Rights and Development (Kumarian Press, Sterling Virginia 2004) 40-41.

10 Paul H. Brietzke, 'Consorting with the Chameleon, or Realizing the Right to Development' (1985) 15 California Western International Law Journal 560, 582.

${ }^{11}$ Uvin, supra n. 9, 40-42.

12 Paul j. Nelson and Ellen Dorsey, 'At the Nexus of Human Rights and Development: New Methods and Strategies of Global NGOs’ (2003) 31 World Development 2013. 
M'baya, therefore, suggested creating the right to development as a means to integrate 'an emancipatory ideal of development into international human rights law'. ${ }^{13}$ Five years later in 1977, M'baya, by then acting as the Chairperson of the UN Commission on Human Rights, continued to roll what Peter Uvin termed the 'snowball' of the right to development, ${ }^{14}$ leading the Commission to launch a study about the international dimensions of the right to development as a human right'. ${ }^{15}$ This study recommended creating this right, as part of the wave of third generation of human rights that emerged during the 1960's and 1970's. ${ }^{16}$ This study, as Jack Donnelly suggests, essentially led to the creation of the right, ${ }^{17}$ although some argued that this right was not created out of thin air, but rather reflects the normal course of development in international human rights law, which sought to promote solidarity and cooperation since the 1948 UDHR. $^{18}$

The Commission on Human Rights' study did not pass without attention, and debates about the meaning of the right to development, its connection to the social policy of 'development', and its relationship to other human rightsbegan to take place. ${ }^{19}$ On the positive level, these debates resulted in the adoption of the Declaration on the Right to Development by the General Assembly in 1986 ('The Declaration'). ${ }^{20}$ The adoption process, as well as the many academic debates that occurred around that time, took place in parallel to the drafting process of the Convention on the Rights of the Child. Despite the coincidence in time, children were neither considered as right holders, nor as beneficiaries of the general right to development, ${ }^{21}$

${ }^{13}$ Ibid

${ }^{14}$ Uvin, supra n. 9, 40.

${ }^{15}$ UN Commission on Human Rights Resolution 4 (XXXIII) of 21 February 1977.

${ }^{16}$ On third generation human rights see Philip Alston, 'A Third Generation of Solidarity Rights: Progressive Development or Obfuscation on International Human Rights Law?' (1982) 29 Netherlands International Law Review 307.

17 Jack Donnelly, 'In Search of the Unicorn: The Jurisprudence and Politics of the Right to Development' (1985) 15 California Western International Law Journal 473, 478.

${ }^{18}$ Philip Alston, 'The Shortcomings of a "Garfield the Cat" Approach to the Right to Development' (1985) 15 California Western International Law Journal 510; See also Dinah Shelton, 'A Response to Donnelly and Alston' (1985) 15 California Western International Law Journal 524, 526. The understanding development as a commitment of international solidarity is reflected by Article 4 of the Convention on the Rights of the Child as well. See Wouter Vandenhole, 'Economic, Social and Cultural Rights in the CRC: Is There a Legal Obligation to Cooperate Internationally for Development?' (2009) 17 International Journal of Children's Rights 23.

19 See, for example, Philip Alston, 'Making Space for New Human Rights: The Case of the Right to Development' (1988) 1 Harvard Human Rights Yearbook 3; Stephen Marks, 'The Human Right to Development: Between Rhetoric and Reality' (2004) 17 Harvard Human Rights Journal 137, 138-141; See also Margot Salomon, Global Responsibility for Human Rights (Oxford University Press, Oxford 2007) 64-109; Daniel J. Whelan, Indivisible Human Rights (University of Pennsylvania Press, Philadelphia 2010) 167-168.

${ }^{20}$ Adopted by General Assembly Resolution 41/128 of 4 December 1986.

${ }^{21}$ Noam Peleg, 'What Do We Mean When We Speak About Children's Right to Development?' in Farhad Malekiam and Kerstin Nordlöf (eds) The Sovereignty of Children in Law (Cambridge Scholarly Publishing, Cambridge 2012) 134-156. 
and the Declaration is silent concerning children. From the perspective of international children's rights law, even after India suggested including a right to development in the Convection on the Rights of the Child, ${ }^{22}$ neither this Declaration nor the debates on the right were raised in the drafting process of the Convention. The two rights have been debated, developed and created in parallel. In 1993, the Vienna Declaration and Programme of Action, which was adopted at the end of the World Conference on Human Rights, reaffirming the 1986 Declaration recognition of development as a human right. ${ }^{23}$ This time, children were not ignored and the Vienna Declaration explicitly acknowledged children as right holders of the general right to development. ${ }^{24}$

\section{The Meaning of 'Development' in the 'Right to Development'}

The Declaration expands the meaning of the right to development beyond its original purpose as an instrument of solidarity, ${ }^{25}$ defining it as

'an inalienable human right by virtue of which every human person and all people are entitled to participate in, contribute to, and enjoy economic, social, cultural and political development, in which all human rights and fundamental freedoms can be fully realised' (Article 1(1))

This definition refers to four domains of development: Economic, social, cultural and political. All four are connected to societies and states and, unlike the developmental domains protected by the Convention on the Rights of the Child, are not intrinsic aspects of the individual. Russel Barash asserts that the difficulty in understanding this definition of development comes from the interrelated dimensions it includes, and the uncertainty about the identity of the right holder or holders. ${ }^{26}$ Keeping these two difficulties in mind, a textual reading suggests that the right to development can be understood as a right to enjoy the

\footnotetext{
${ }^{22}$ See chapter two.

${ }^{23}$ UNGA, Vienna Declaration and Program of Action (12 July 1993), UN Doc A/CONF.157/23; See Obiora, supra n. 6, 379-380.

${ }^{24}$ See Articles 18, 21, 29 and 45-53.

25 Hans-Otto Sano, 'Development and Human Rights: The Necessary, But Partial Integration of Human Rights and Development' (2000) 22 Human Rights Quarterly 734, 736; See also Allan Rosas, 'The Right to Development' in Asbjørn Eida et al (eds) Economic, Social and Cultural Rights (2 ${ }^{\text {nd }}$ edition, Kluwer International, The Hague 2001) 119-130, 123-124.

${ }^{26}$ Russel L. Barash, 'The Right to Development as a Human Right: Results of the Global Consultation' (1991) 13 Human Rights Quarterly 322, 322.
} 
outcome of four domains of collective development, whereas during the process of development all the rights and freedoms of individuals should be 'fully realised'.

'Development' is further defined by the Declaration as 'the constant improvement of wellbeing of the entire population and of all individuals...' (Article 2(3)), thus emphasising the importance of non-discrimination and inclusion. ${ }^{27}$ The right to development therefore reaches beyond the "notions of economic growth to the expansions of opportunities and capabilities to enjoy those opportunities,. ${ }^{28}$ Donnelly rejects this line of interpretation, claiming that 'individual development is a likely (although not a necessary) consequence of respect for economic and social right [s]'. ${ }^{29}$

Critics of the right to development described it a 'hopelessly utopian', ${ }^{30}$ as an 'entirely pointless' idea within the framework of international human rights law, or claimed that it is nothing more than an 'umbrella concept' lacking any distinct meaning. ${ }^{31}$ Arjun Sengupta, the former UN Independent Expert on the Right to Development, responded by saying that the right should neither be seen as a title that joins civil and political rights with social and cultural rights, ${ }^{32}$ nor should it be perceived as the summary of a set of rights. All human rights, he asserted, are interrelated and interdependent under the right to development, and all are essential foundationsfor the realisation of the right to development.

According to this approach, the right should be perceived as an integrated whole, ${ }^{33}$ which means the right to 'exercise of the full range of rights; as a goal it is the self-actualization of people through the exercise of their rights'. ${ }^{34}$ This interpretation goes beyond the immediate, inherent benefit of realising different human rights, preferring a more abstract conception of self-actualization'. ${ }^{35}$ This idea reflects the original ideas of emancipation that led to the creation of this right, which is also reflected by the Declaration, which states that the right 'also implies the full realisation of the right of people to self-determination which includes

\footnotetext{
27 Arjun Sengupta, 'The Human Right to Development' (2004) 32 Oxford Development Studies 179, 180.

28 Sengupta, 'Realising the Right to Development', supra n. 9, 566.

29 Donnelly, supra n.17.

${ }^{30}$ Richard Warren Perry, 'Rethinking the Right to Development: After the Critique of Development, After the Critique of Rights' (1996) 18 Law \& Society 225, 228.

31 Rosas, supra n. 25, 129.

32 Arjun Sengupta, 'Implementing the Right to Development' in Nico Schrijver and Friedl Weiss (eds) International Law and Sustainable Development - Principles and Practice (Martinus Nijhoff Publishers, Leiden 2004) $341-377,343$.

33 Ibid, 343.

${ }^{34}$ J. O'Manique, 'Human Rights and Development' (1992) 14 Human Rights Quarterly 78, 101.

${ }^{35}$ Ibid.
} 
their inalienable right to full sovereignty over all their natural wealth and resources' (Article $1(2))$.

An alternative, but related, approach to the articulation of this right as an integrated right is to conceptualise the right to development as a vector. According to Sengupta, analysing the right to development as a vector right means that it should be seen:

'as a composite right, where all the rights are realised together, recognizing their interdependence, not just their aggregation. The whole is greater than the sum of the parts... the component rights are related in a non-linear way with positive feedback... it is a composite of all the human rights implemented in an integrated manner as a part of a development program in the context of the growth of resources'. ${ }^{36}$

Donnelly argues that even according to this interpretation, 'development' is the objective of human rights as a whole, and not a standalone concept. ${ }^{37} \mathrm{He}$ might be too harsh. A meaning of 'development' in 'the right to development' can be concluded in light of the Declaration. 'Development' refers to emancipation, growth and prosperity. As a human right, it means that people have the right to growth, which is assisted by the realisation of all of their other human rights. I return to these ideas, including the conceptualising of the right to development as a composite right, in the next chapter.

\section{Distinguishing Between The Process of Development and Its Outcome}

The general right to development asks to differentiate between two aspects of development: the process of development and its outcome. The Declaration's preamble states that 'the human person is the central subject of the development process'. The goal of the developmental process is to constantly improve the "well-being of the entire population and of all individuals' (Article 2(3)). According to Sengupta, both the process and the outcome of development are equally important. ${ }^{38}$ Thus, the two should not be differentiated, and the process should not be seen as a means to an end. At this point Lesley Obiora adds that the process of development itself is important as it enables people to exercise their human rights. ${ }^{39}$ According to this line of reasoning, the process of development should be seen as

\footnotetext{
36 Sengupta, 'The Human Right to Development', supra n. 27, 183.

37 Donnelly, supra n.17, 484.

38 Sengupta, 'The Human Right to Development', supra n. 27, 183.

${ }^{39}$ Obiora, supra n. 23, 389.
} 
serving an end in and of itself. Treating the process of development as intrinsic in its own right,therefore, ensures respecting people's human rights, dignity and agency throughout the process, and not only in its end. Following the same logic, O'Manique suggests not to see these two aspects in polarised terms, proposing to understand the differences between them from the perspective of the right holders. From this perspective, the right to development can be understood as a right that protects both the process and the outcome of development, while actualizing the 'human potential as defined by the individual and his or her community'. ${ }^{40}$

This analytical distinction between the outcome and process of development is valuable when thinking about children. Under the 'human becomings' paradigm, the concern is placed on the end result of the development process. The expectation is to see children transform into adults, and only then gain agency. Whereas according to the 'human being' paradigm the process of maturation is respected; the child is perceived as a right holder and the inherent importance of the maturation process is acknowledged. A question that should be asked is whether the child's right to development protects the process of development (i.e the process of growing up) or the outcome of this process, namely the transformation of the child into an adult.

\section{$\underline{\text { Respect for People's Agency and Their Right to Participation }}$}

A key aspect of the right to development is the recognition and respect of people's agency and promoting their right to participation. Article 1 of the Declaration expresses this ideal clearly, stating that 'every human person...[is] entitled to participate in, contribute, and enjoy economic, social, cultural and political development'. The Declaration further adds that individuals 'should be active participants' of the right to development (Article 2(1)), since a 'meaningful participation' of people is essential to the realisation of the right to development, and it should be ensured while the process of development takes place (Article 2(3)).

Respecting people's agency is the reason for, as well as the outcome of, respecting their right to self-determination. ${ }^{41}$ Participation can have a positive effect on the elimination of exclusion and community mobilization efforts. ${ }^{42}$ Granting people the right to participate (where the right to vote is only a partial expression of participation) enhances democratic

\footnotetext{
${ }^{40}$ J. O'Manique, 'Development, Human Rights and Law' (1992) 14 Human Rights Quarterly 383, 384.

${ }^{41}$ Alston, 'The Shortcomings of a "Garfiled the Cat" Approach to the Right to Development', supra n. 18, 512; Arjun Sengupta, 'The Human Right to Development' supra n. 27, 180-181.

${ }^{42}$ Barash, supra n. 26, 329.
} 
values $^{43}$ and empowers people. Therefore, participatory processes should be 'centred around the concept of equity and justice', ${ }^{44}$ and 'decisions have to be taken with the full involvement of the beneficiaries, keeping in mind that if this involves a delay in the process, that delay should be kept to a minimum'. ${ }^{4}$

The principle of participation conforms to the perception of people as the end rather than means of development. Participation gives people a voice, and transforms them into active agents of change, instead of being passive targets of economic development policy or political oppression. In that sense, there is an important similarity between the right to development and the protection of children's right to participation in Article 12 of the Convention, and the 'human beings' conception of childhood. As we saw in chapter three, the Committee tends not to link the protection for children's development and their right to development with the right to participation, as part of its failure to respect children's agency with respect to their development.

\section{$\underline{\text { Between an Individual and a Collective Right }}$}

As mentioned earlier, the origins of the right to development lie in the emancipatory ideas of the 1960's and 1970's. Therefore, the right protects the collective idea of self-determination and economic development, perceiving people as active objects and not as means to an end. ${ }^{46}$ The Declaration states that people should enjoy the right both as individuals and as a collective. Article 1(1) states that it is the right of 'every human person and all people'. People ‘individually and collectively' (Article 2(2)) are responsible for development, though states bear the "duty to formulate appropriate national development policies that aim at the constant improvement of the well-being of the entire population' (Article 2(3)).

In other clauses, the Declaration divides the right holders according to different goals of 'development'. For example, as a collective right, people are the ones who enjoy the right to self-determination as part of the right to development (Article 1(2)). Individuals, on the other hand, are the central subjects of development (Article 2(1)). However, Obiora rightly claims

\footnotetext{
${ }^{43}$ Salomon, supra n.19, 181.

${ }^{44}$ Sengupta, 'Realising the Right to Development', supra n. 9, 566.

${ }^{45}$ Ibid, 568.

${ }^{46}$ Shelton, supra n. 18, 525.
} 
that such an approach first requires reconciling the 'antitetical and hierarchical' relationship between the two dimensions, ${ }^{47}$ as reflected in the Declaration itself.

According to Obiora's analysis, states have the duty to respect this right for the benefit of their people, but they are not the right holders. ${ }^{48}$ Obiora further suggests that 'the assumption is that the satisfaction of the collective right and the right to development in particular is a necessary condition for the materialization of the individual right' ${ }^{49}$ Donnelly asserts that the individual dimension of the right prevails and, therefore, the right to development should be interpreted as

'a right to pursue full personal development along all major dimensions of human life. If all human rights aim at the further development of the human person, then a right to full personal development can stand as a summary of traditional rights'. ${ }^{50}$

To a large extent, this definition is aligned with the way in which the child's right to development is currently interpreted. Nonetheless, this approach undermines the categorization of the right to development as an independent right that has a distinct meaning. Paul Brietzke views the right to development as a right of individuals that can only be realised through a collective effort. Brietzke asserts that every person should be perceived as a right holder, but the right will not be realised by the actions of an individual alone. Each and every right holder should be located 'at the beginning and at the end of the [development] process', while 'the middle of the process, the implementing of the right to development through a broadly-defined production, can only be achieved collectively and through interdependent domestic sectors and, ultimately, the international community'. ${ }^{51}$ This perspective echoes the original ideas of collective mobilization as a vehicle to fulfil individual development. This approach assumes that a collective development will be the means to facilitate the realisation of the personal right to development. This point is further developed by the Capability Approach, as will be discussed below.

Sengupta approaches this tension from a different perspective, claiming that the right 'incorporates personal rights', but nevertheless 'has to be implemented mainly by collective

\footnotetext{
${ }^{47}$ Obiora, supra n. 23, 359.

${ }^{48}$ Brietzke supra n. 10, 566.

${ }^{49}$ Obiora supra n. 23, 389.

${ }^{50}$ Donnelly, supra n. 17, 501.

${ }^{51}$ Brietzke, supra n. 10, 593.
} 
actions'. ${ }^{52}$ But even Sengupta eventually admits that the right 'aims at the constant improvement of the well-being of the entire population on the basis of their active, free and meaningful participation and the fair distribution of benefits resulting from, ${ }^{53}$ further emphasising the importance of economic growth as 'both an objective and a means' for development. ${ }^{54}$ This comment suggests that the tension between the collective and individual dimensions of the right to development leans toward favouring collective progress as a means of facilitating personal emancipation. But this approach advances the view that only economic progress can create the necessary material condition for every human being to enjoy the full scale of human rights. To some extent, this conclusion undermines the view that people are at the centre of development. It also ignores other domains of development, such as emotional development and psychological development, which are effected by personal relationships (for example between family members) and not only by materialistic conditions of living.

Conclusion - What Can the Right to Development Contribute to the Analysis of the Child's Right to Development?

The main challenge in using the 'general' right to development in analysing the child's right to development, is resolving the contrasting aims of these two rights. These two rights share the yardstick of growth: one of growth in economy and the other of personal growth. While the current interpretation of the child's right to development focuses on the process of maturation of the individual child, the 'general' right to development holds a more complex notion of 'development'. The idea of development of the latter combines a collective progress with an emphasis on economic growth, while equally valuing personal emancipation. This is where the two rights meet, since they both essentially seek to enable every human being to fulfil her or his human potential.

The analysis of the child's right to development can benefit from this specific articulation of 'development', and the thematic distinction between the process of development and its outcome. It appears that thus far, the interpretation of the child's right to development seeks to protect the outcome of the process - enabling the child to 'become' an adult. But if the process of development is deemed important as well, it will reaffirm the significance of the

\footnotetext{
52 Sengupta, 'Realising the Right to Development', supra n. 9, 569.

${ }^{53}$ Sengupta, 'Implementing the Right to Development', supra n. 32, 346.

${ }^{54}$ Ibid, 347.
} 
time of childhood, respect the child as a right holder and respect the child's agency and the child's right to participation. In other words, it will enable to channel the 'human beings' model into the interpretation of the child's right to development.

The relevance of the differentiation between the collective and individual aspects to the analysis of the child's right to development will be discussed in more details in the next chapter.

\section{The Capability Approach and the Child's Right to Development}

This section analyses the Capability Approach's conception of development, its emphasis on respecting people's agency and the potential contributionsof this approach to the analysis of the child's right to development. The section begins by describing the background that led to the creation of theCapability Approach. It follows with a discussion about the concept of 'human development', delineating the understanding of 'development' as 'freedom', and its nexus with the concepts of agency and capabilities. The third part analyses how these conceptions can be used to analyse the child's right to development. Some of the concepts and terms that this section discusses overlap with the concepts and terms employed in the previous section about the 'general' right to development. This overlap is unavoidable due to the interrelatedness between the two, and influence on each other.

I argue that utilising Capability Approach in the interpretation process of the child's right to development can help overcome two of the shortcomings in the current approach to this right, namely the lack of recognition of children's agency and the difficulties in concretising children's development. Similarly to the contribution that the 'general' right to development made with respect to agency, the Capability Approach provides even further theoretical justifications, as well as practical implications that follow, for the respect of children's agency.

The Capability Approach (or 'approaches') ${ }^{55}$ is based on the seminal work of Amartya Sen and Martha Nussbaum.The Capability Approach has constituted a paradigm shift in the understanding of 'development' in economics and political science, suggesting that 'development' should not be thought of only in terms of promoting economic growth as a

\footnotetext{
${ }^{55}$ It has also been suggested that it should be called 'the capability creation'. Des Gasper, 'What Is the Capability Approach? Its Core, Rationale, Partners and Dangers' (2007) 36 Journal of Socio-Economics 335, 346.
} 
means of eliminating poverty and satisfying people's 'basic needs' ${ }^{56}$ But rather, 'development' should be comprehended as a process that facilitates people's ability to live lives worth living. ${ }^{57}$ Development, in a nutshell, is 'freedom'. ${ }^{58}$ Thus far, children have been largely left out of the debates concerning the Capability Approach, and only handful of studies touches upon this issue. ${ }^{59}$ Most recently, in 2012, Martha Nussbaum and Rosalind Dixon joined this emerging trend, and have argued that the Capability Approach can be used to justify recognition of children's human rights. ${ }^{60}$ Dixon and Nussbaum's arguments will be discussed in detail later, but for now it is important to note that their discussion on children's rights overlooked the right to development. This thesis will not exhaust all questions that the relationship between the Capability Approach, children and children's rights raises. It focuses on two of themonly: should the Capability Approach's conception of development be employed in analysing the child's right to development, and if the answer is affirmative, then how.

\section{The Meaning of 'Development' According to the Capability Approach}

The Capability Approach rejects the focus on economic growth, as the traditional conception of development suggests, ${ }^{61}$ nor does it focus, like international children's rights law, on personal domains of development like psychological development. Rather, the Capability Approach aims to advance people's quality of life and well-being by expending their capability to increase their 'real opportunities', in order to enable people to have a stake inshaping their own lives. ${ }^{62}$ The Capability Approach also looks beyond one's capabilities, and draws attention to structural implications of disability, social exclusion, chronic poverty, democratic values and human dignity, considering the influence of these factors on one's

\footnotetext{
${ }^{56}$ Gustavo Esteva, 'Development' in Wolfgang Sachs (ed) The Development Dictionary (Zed Book, London 1992) 6-25; Paul Streeten and Shahid Javed Burki, 'Basic Needs: Some Issues' (1978) 6 World Development 411; On women's basic needs see Ingrid Palmer, 'Rural Women and the Basic Needs Approach to Development' (1977) 115 International Labour Review 97.

57 Andrew Moore and Roger Crisp, 'Welfarism in Moral Theory' (1996) 74 Australian Journal of Philosophy 598; Lawrence Hamilton, 'A Theory of True Interests in the Work of Amartya Sen' (1999) Government and Opposition 516.

${ }^{58}$ Amartya Sen, Development as Freedom (Oxford University Press, Oxford 1999).

${ }^{59}$ Flavio Comim et al, 'Introduction - Theoretical Foundations and the Book's Roadmap' in Mario Biggeri et al (eds) Children and the Capability Approach (Palgrave, Hampshire 2011) 3-21, 6.

${ }^{60}$ Rosalind Dixon and Martha Nussbaum, 'Children's Rights and a Capability Approach: The Question of Special Priority' (2011-2012) 97 Cornell Law Review 549.

${ }^{61}$ On that aspect of development see Steven Pressman and Gale Summerfield, 'The Economic Contribution of Amartya Sen' (2000) 12 Review of Political Economy 89.

${ }^{62}$ Dixon and Nussbaum, supra n. 60, 557.
} 
freedom. ${ }^{63}$ According to Sen, freedom to choose is 'both the primary end' and 'the principle means of development ${ }^{64}$ Expanding the freedoms that people have enriches their lives, ${ }^{65}$ and 'allows them to be fuller social persons, exercising our own volitions and interacting with and influencing - the world in which we live'. ${ }^{66}$ Poverty, according to the Capability Approach, is not lack or materialistic needs, but rather a capability deprivation. Being poor is being in a position where you cannot make meaningful choices about your own life. 'Unfreedom' is a deprivation of capabilities, such as famine or being under nourished, having little access to social services such as health care or functional education, access to clean water, or having no economic and social security. 'Unfreedom' can also be manifested in broader terms, as an inequality 'between women and men [and] denial of political liberty and basic civil rights'. ${ }^{67}$

Sen argues that social exclusion and heterogeneity are two key factors in generating inequalityand unfreedom. He asserts that social, political, economic and cultural power structures constitute the core causes of unfreedoms, since they prevent the marginalised from benefiting from economic prosperity, thus neutralizing the 'trickle down' effect. A related issue is household inequality. Sen claims that increasingthe family income as a means of eliminating household poverty is false, since it is based on the perception of ahousehold equality, where welfare is distributed fairly. This perception ignores realitiesof many women, children and the elderly, where decisions are being taken for them on the bases of patriarchal order, which means that they are less likely to have their needs met (and girls are usually discriminated against more then boys). ${ }^{68}$

The Capability Approach further challengesthe perception of people, mainly poor people, as a homogenous group, claiming that the perception of homogeneity ignores gender, disabilities, age or illness as relevant factors to the levels of income and accessibility to social services necessary to maintain similar standard of living. For example, a person with disability spends a larger percentage of his income on buying medications and treatments (and he also need more access to health care services), in comparison tothe percentage that a person without a disabilityand a same level of income spends on his health. Therefore, in order to 'develop'

\footnotetext{
${ }^{63}$ Sen, Development as Freedom, supra n. 58.

${ }^{64}$ Ibid, 16.

${ }^{65}$ Sabina Alkire, 'Using The Capability Approach: Prospective and Evaluative Analyses' in Flavio Comin et al (eds) The Capability Approach (Cambridge University Press, Cambridge 2008) 26-50, 28.

${ }^{66}$ Sen, Development as Freedom, supra n. 58, 14.

${ }^{67}$ Ibid, 15.

${ }^{68}$ Ibid, 70-71.
} 
and to maintain a similar standard of living, these two people need different resources. The same logic applies to children. Children also have their own unique needs that ought to be met, in order to be able to live dignified lives. ${ }^{69}$

Three concepts are vital to understanding the Capability Approach: agency, functions and capabilities. Respecting people's agency and the idea that people should live their lives according to their own wishes, instead of being bound by a set of choices determined by others, ${ }^{70}$ is one of the main innovations of the Capability Approach. Similar to the 'general' right to development, the Capability Approachsees the individual as 'someone who acts and brings about change, and whose achievements can be judged in terms of her own values and objectives, whether or not we assess them in terms of some external criteria as well. ${ }^{71}$ Participation of people is the best way to realise those personal preferences. Participation guarantees people's freedoms since it 'enhances the ability of people to help themselves and also to influence the world... the concern here relates to what we may call the 'agency aspect' of the individual' ${ }^{72}$ Preventing people from having the ability to choose not only denies their agency but also, according to Nussbaum, 'makes life not worthy of human dignity'. ${ }^{73}$

Functions are 'the various things a person may value being and doing' ${ }^{74}$ Functions include, for example, having a job and being healthy, as well as more abstract ideas, such as happiness. The Capability Approachdoes not offer one definitive set of these types of preferences, ${ }^{75}$ as every person should define her or hisfunctions subjectively. A precondition to being able to define a set of functions and live accordingly is having the necessary capabilities. Sen uses the availability of food as an example to illustrate the connection between functions and capabilities. If a person does not eat, it might be because he simply does not have food, or because he has decided to fast or to go on a diet. ${ }^{76}$ While the latter is a matter of choice (function), the former is a matter of lack of capabilities.

\footnotetext{
${ }^{69}$ Dixon and Nussbaum, supra n. 60, 556-563.

${ }^{70}$ Amartya Sen, Inequality Re-examined (Harvard University Press, Cambridge 1992) 39.

${ }^{71}$ Sen, Development as Freedom, supra n. 58, 18-19.

${ }^{72}$ Ibid, 18.

${ }^{73}$ Martha C. Nussbaum, Creating Capabilities - The Human Development Approach (Harvard University Press, Cambridge 2011) 31.

${ }^{74}$ Sen, Development as Freedom, supra n. 5875.

75 Amartya Sen, 'Human Rights and Capabilities' (2005) 6 Journal of Human Development 151, 157-160.

${ }^{76}$ Sen, Inequality Re-examined, supra n. 70.
} 
Capabilities are therefore 'the range of options a person has in deciding what kind of life to lead', ${ }^{77}$ which 'represent the various combinations of functioning (being and doing) that the person can achieve', ${ }^{78}$ and as such constitutes one's freedom. Nussbaum defines capabilities in slightly different terms, claiming that capabilities are what enable people to execute their human functions. ${ }^{79}$ Capabilities should, therefore, be understood as 'what people are actually able to do and to be'. ${ }^{80}$ According to Nussbaum, all human beings ought to have the freedom to choose whether they exercise these capabilities and in which ways they do so, while the role of the state is to establish the 'material and institutional environment so people are actually able to function'. ${ }^{81}$ Whereas Sen's ideas remain in the abstract, as he does not define the types of capabilities needed in order to be free, Nussbaum suggests a list of ten capabilities that she qualifies as concrete, universal, inseparable and essential to the realisation of human development. The ten capabilities are: life, bodily health, bodily integrity, sense, imagination and thought, emotions, practical reason, affiliation, other species and play and control over one's environment. ${ }^{82}$ Nussbaum asserts that this list is intentionally slightly ambiguous in order to leave a room for every society to elaborate and interpret this list differently, based on its own traditions and histories. ${ }^{83}$

Distinguishing between internal capabilities and substantial freedoms can help to flush out the meaning of 'freedom' and 'capabilities' a bit more. Internal capabilities are the person's intellectual and emotional capacities, fitness and health, learning skills etc. Substantial freedom is the ability to make a choice, which depends on personal capacities as well as the political, social and economic environment as combined capabilities. Based on this distinction, it is argued that if a society would like to promote human capabilities, it ought to support the development of internal capabilities 'through education resources to enhance physical and emotional health, support for family care and love, a system of education and

\footnotetext{
${ }^{77}$ Jean Drèze and Amartya Sen, India: Economic Development and Social Opportunity (Oxford University Press, Oxford 1995) 10.

${ }^{78}$ Sen, Inequality Re-examined, supra n. 70, 4.

${ }^{79}$ Martha Nussbaum, 'Women's Capabilities and Social Justice' (2000) 1 Journal of Human Development 219, 242.

${ }^{80}$ Ibid, 222-223.

${ }^{81}$ Ibid, 235.

${ }^{82}$ Ibid, 230-233. Nussbaum, Creating Capabilities - The Human Development Approach, supra73, 33-34.

${ }^{83}$ Nussbaum, Creating Capabilities - The Human Development Approach, supra73, 40. See Robeyns' claim that such a list should be rejected as it narrows down Sen's approach. Ingrid Robeyns, 'An Unworkable Idea or a Promising Alternative? Sen's Capability Approach Re-examined' (1993) Center of Economic Discussion on Paper 00.30. University of Leuven, Mimeo.
} 
much more. ${ }^{84}$ This distinction clarifies how society can enable production of internal capabilities, while reducing or eliminating the options of people to function in accordance with those capabilities. For example, people can be given access to education in order to develop their capability to express themselves. But if soon after they are denied the right to freedom of expression, it means that their combined capability is denied. ${ }^{85}$ Society, therefore, cannot provide and produce combined capabilities 'without producing internal capabilities' ${ }^{86}$ This distinction is vital with respect to children, as will be furtherelaborated in the next section.

Another aspect of capabilities that should to be taken into consideration is what Jonathan Wolff and Avner De-Shalit describes as 'Capability Security'. Wolff and De-Shalit claim that providing people with capabilities alone does not fulfil the goal of extending freedom, because people need some level of certainty about their future in order to enjoy the ability to choose. The 'Capability Security' means that issues concerning the length and time in which each capability will be protected, and the extent of which it will be protected, must be addressed. Wolff and De-Shalit suggest that having a capability protected (for example the right to education) in a constitutional document, which cannot be easily amended, provides sufficient protection and security, in comparison to having capabilities guaranteed in law, in administrative acts, in customs or not guaranteed at all.

In light of this approach, Nussbaum is right to ask what new roles, if any, this concept ascribes to states and to courts. ${ }^{87}$ After all, even this kind of constitutional instrument does not provide the necessary protection, if a person lacks access to courts or does not have confidence in the judiciary. ${ }^{88}$ For children, as will be discussed later, capability security is important due to their lack of the political influencerequired to make capabilities accessible and available (which influence their combined capabilities).

\footnotetext{
${ }^{84}$ Nussbaum, Creating Capabilities - The Human Development Approach, supra73, 21.

${ }^{85} \mathrm{Ibid}, 23$.

${ }^{86}$ Ibid.

${ }^{87}$ Ibid, 43.

${ }^{88}$ Jonathan Wolff and Avner De-Shalit, Disadvantage (Oxford University Press, Oxford 2007). See also Sano,supra n. 25, 749-750. To some extent, this argument is similar to the connection that some, like David Kennedy, make between the rule of law, access to justice and development). David Kennedy, 'Laws and Development' in John Hatchard and Amanda Perry-Kessaris (eds) Law and Development: Facing Complexity in the $21^{\text {st }}$ Century (Cavendish, London 2003) 17-26.
} 
In this section I argue that childrenshould be perceived as entitled to develop in the Capability Approach's sense of the word. Utilising the Capability Approach's conception of development with regard to the child's right to development can remedy two shortcomings in the current interpretation of this right: lack of recognition in children's agency and ignorance of their right to participation; and insufficient concretization of the right. It can also enableus to re-define the meaning of 'children's development' and thus of their right to development.First, I will address the preliminary questions concerning the adaptability of the Capability Approachto international human rights law, and the nexus between the Capability Approachand children.

The role of children in the Capability Approach has been rarely addressed by either Sen or Nussbaum, until very recently. I argue that one of the main reasons for this silence isSen's adoption of the 'human becomings' model to childhood, denoting that children will have to enjoy their freedoms in the future, when they become competent adults. ${ }^{89}$ The 'opportunities children have today and will have tomorrow', Sen writes, are 'in line with what they can be reasonably expected to want, is a matter of public policy and social programmes'. ${ }^{90}$ Competency, therefore, is the key difficulty that Sen sees in linking between children and the Capability Approach. Madoka Saito expresses a similar concern, when he asks 'how can we apply the Capability Approach to children, since children are not mature enough to make decision by themselves?' 91 Likewise, Biggeri et al assert that the 'Capability Approach obviously implies the individual's capacity for self-determination, which may not apply to children'. ${ }^{92}$

The questions of children's competence and capacity to choose are not unique to this context. These questions are at the heart of the debates concerning children's rights, and are being asked with respect to almost every aspect of the child's life, including, for example, consent to medical treatment, ${ }^{93}$ the age of criminal responsibility, ${ }^{94}$ or the right to vote. ${ }^{95}$ The debates

\footnotetext{
${ }^{89}$ Saito, Supra n. 1, 25.

${ }^{90}$ Amartya Sen, 'Children and Human Rights' (2007) 1 Indian Journal of Human Development 235, 241.

${ }^{91}$ Saito, Supra n. 1, 25.

${ }^{92}$ Mario Biggeri et al, 'Children's Agency and the Capability Approach: A Conceptual Framework', In Mario Biggeri et al (eds) Children and the Capability Approach, supra n. 59, 22-45, 24.

${ }^{93}$ A leading UK case is Gillick v. West Norfolk and Wisbech Area Health Authority [1986] AC 112. See Michael Freeman, 'Rethinking Gillick' (2005) 13 International Journal of Children's Rights 201.

${ }^{94}$ Different countries subscribe different age of criminal responsibility, ranging from the age of 7 to the age of 18. Angela Melchiorre and Ed Atkins, At What Age Are School-Children Employed, Married and Taken to Court? (Right to Education Project, London 2011) 30-32.
} 
with respects to these issues are relevant in our context as well. Predominantly, it is a matter of conception concerning children's entitlement, and not 'empirical' capacity, to choose. Therefore, I suggest that the Capability Approachshould be deemed as relevant for children for all the reasons that it is relevant to all people, including the elderly and the disabled person, and for the most marginalised groups in particular. Claiming that Capability Approachis not relevant to children based on the claim that children lack the capacity to chooseundermines the core principle of the Capability Approachitself. One cannot advocate for respecting the human dignity and agency of people, who formerly were at the margins of their societies, were perceived as lacking of (certain) capacities, and at the same time deny this universal principle from children, by using the very same arguments. The unsubstantiated repeated proposition that children lack required capacity is a self-fulfilling prophecy, leading to a situation where children are also denied the opportunity to challenge this presumption, perpetuating their denial of agency. ${ }^{96}$ This attitude creates a vicious circle that excludes children from the ability to develop, in line with the Capability Approach'sconception of development as freedom.

Nussbaum's definitions of internal capabilities and combined capabilities of children deny children the opportunity to 'develop' in the Capability Approach's sense of the word as well. A change in this attitude will happen if children's internal capabilities are developed, primarily by education, and if they begin to be seen as active agents. Recognising children's agency is a theme that keeps reappearing in every analysis concerning the child's right to development. Therefore, we first need to discuss the relationship between the Capability Approach and human rights law in general.

Sen distinguished between the conceptual idea of human rights and human rights law, claiming that the moral strength of the former does not require the existence of the latter. On practical levels, Sen asserted that human rights law is a good rhetorical tool for creating and imposing obligations on states to provide the capabilities necessary for human development. ${ }^{97}$ Referring to the structure of international human rights law, Séverine Deneulimasserts that employing the Capability Approach'sconception of development

\footnotetext{
95 Marc Jans, 'Children as Citizens' (2004) 11 Childhood 27; John Wall, 'Can Democracy Represent Children? Towards a Politics of Difference' (2012) 19 Childhood 86; Jeremy Roche, 'Children: Rights, Participation and Citizenship' (1999) 6 Childhood 475; Aoife Nolan, Children's Socio-Economic Rights, Democracy and the Courts (Hart, Oxford 2011) 43-92.

${ }^{96}$ On this point see Katherine Hunt Federle, 'Rights Flow Downhill' (1994) 2 International Journal of Children's Rights 343.

97 Amartya Sen, 'Capabilities and Well-Being' in Martha Nussbaum and Amartya Sen (eds) Quality of Life (Oxford University Press, Oxford 1993) 30-53.
} 
enables to 'look at the institutional framework that allows that right to be fulfilled' ${ }^{98}$ According to this approach, human rights analysis does not employ Capability Approach'sconception, but rather utilises the Capability Approachin order to define social structures. By focusing on social instruments and law, both approaches ignore the human right holders as human subjects.Nussbaum is much more in favour of connecting the Capability Approach and human rights, including children's rights, than Sen. ${ }^{99}$ As noted earlier, most recently Dixson and Nussbaum argued that the Capability Approach provides further justification for recognising children as human rights holders, and for giving children's socio-economic rights a priority. ${ }^{100}$ Furthermore, they argued that children's entitlement to their human dignity justifies recognising 'a range of rights for children with sensitivity both to children's welfare needs and to children's agency'. ${ }^{101}$ In their discussions about children's competence and agency, Dixon and Nussbaum compare children's rights to the rights of people with intellectual disabilities, arguing that recognition of children's rights is based on a similar "moral claim of all human beings to be afforded full human dignity, regardless of their capacity for rational or reasoned participation in public or civil life' ${ }^{102}$ Therefore, taking the Capability Approach perspective, they claim that children's 'vulnerability' 103 (or a 'cost effective analysis') ${ }^{104}$ justifies affirmative action policies toward children, which aim to provide children the necessary capabilities to be free.

The distinction between capacities and respect for human dignity and human rights is important, but nevertheless problematic because children are once again being measured against adult-tailored standards. Thus, perpetuating the notion that a competent adult is the threshold that children must meet. The comparison to people with intellectual disabilities contradicts the perception of childhood as a mode of change. While children are 'developing' and, therefore, capable of change, the common perception of adults with intellectual disabilities is that their disability is static (that until medical science will solve the relevant neurobiological problems).

\footnotetext{
${ }^{98}$ Séverine Deneulim, 'Ideas Related to Human Development' in Séverine Deneulim and Lila Shahani (eds) An Introduction to the Human Development and Capabilities Approach (Earthscan, London 2009) 49-70, 60.

${ }^{99}$ Martha Nussbaum, 'Human Capabilities, Female Human Beings' in Martha Nussbaum and Jonathan Glover (eds) Women, Culture and Development: A Study on Human Capabilities (Oxford University Press, Oxford 1995) 61-104; Martha Nussbaum, 'Capabilities as Fundamental Entitlements: Sen and Global Justice' (2003) 9 Feminist Economics 33.

${ }^{100}$ Dixon and Nussbaum, supra n. 60.

${ }^{101}$ Ibid, 553.

${ }^{102}$ Ibid.

${ }^{103} \mathrm{Ibid}$, 573-578.

${ }^{104}$ Ibid, 578-584.
} 
Biggeri has a more practical suggestion, claiming that 'human rights can be used as the main argument for defending a list of relevant capabilities for children', ${ }^{105}$ and that the Capability Approach 'can become a framework for normative evaluation and policy implementation. Therefore, it seems that the libertanian-inspired human rights approach and the Capability Approachcan dialogue and complement each other quite well' ${ }^{106}$ Ballet et al take this idea forward, suggesting aconcrete mode of operation.

'in the case of children, on the one hand human rights can be used as the main argument for defending a list of relevant capabilities for children, and on the other the Capability Approach can become a framework for normative evaluation and policy implementation. ${ }^{107}$

I suggest adopting this conclusion with only one change: in the case of children, the Capability Approachcan inform the interpretation and implementation of the Convention in general, and the right to development in particular. I will return to this idea in detail later, when discussing the contribution of the Capability Approachto concretising the child's right to development.

Polly Vizard claims that despite Sen's reservations concerning employing human rights terminology with respect to the Capability Approach,international human rights law can help to generate 'a minimal list of central and basic capabilities with universal coverage'. ${ }^{108}$ Likewise, Deneulim suggests that both the Capability Approachand human rights are based on 'the maxim that individuals should not be treated as a means but as an end... the human rights approach enhances human development with its stronger focus on obligations and duties, while the latter remains an evaluative framework for assessing states of affairs' ${ }^{109}$ A different, more substantive issue, with regard to employing the Capability Approachin the context of human rights framework, is the question of equality and discrimination. While the recognition of diversity among people and the impacts that disadvantages have on people's development is central to the Capability Approach, Deneulim claims that 'the human rights approach does not necessarily take such differences into account', ${ }^{110}$ and, therefore, will not

\footnotetext{
105 Mario Biggeri et al, 'Children's Agency and the Capability Approach: A Conceptual Framework', In Mario Biggeri et al (eds) Children and the Capability Approach, supra n. 59, 22-45, 39-40.

${ }^{106}$ Ibid, 39-40.

${ }^{107}$ Ibid.

108 Polly Vizard, 'Specifying and Justifying a Basic Capability Set: Should the International Human Rights Framework be Given a More Direct Role?' (2007) 35 Oxford Development Studies 225, 235.

109 Deneulim, supra n. 98, 60.

${ }^{110}$ Ibid, 61 .
} 
fulfil the Capability Approach'sgoals. The problem with this liberal analysis is that it ignores the notion of substantive equality and affirmative action.

Human rights law does not ignore differences between people; on the contrary, it respects these differences and factors them in. The 2007 Convention on the Rights of People with Disabilities serves as a good example of this approach. ${ }^{111}$ Similarly, the differences between children and adults can and should be recognised under an equality and non-discrimination analysis. Such an approach upholds the child's right to non-discrimination and takes into account relevant differences.

\section{Fostering The Recognition of Children's Agency and Participation}

An important contribution of the Capability Approachto the analysis of the child's right to development is fostering the recognition of children's agency, both of the individual childand of children as a collective group. Such recognition will place children at the heart of the process of development, and will ensure that their right to participate and to enjoy both the process and outcome of development is realised. In that respect, the argument shares similarities to the conclusions of the analysis of the 'general' right to development.

As chapters one-three have demonstrated,the lack of recognition of children as agentshas led in the pastto a perception of children as their father's property (and unfortunately is some cases this perception is still valid today), as passive members of the family who are subjugated to the control of others, and as passive beneficiaries of welfare policies. Furthermore, despite claims that a paradigm shift in childhood studies has happened, insufficient respect for children's agency underpinned the drafting process of the Convention on the Rights of the Child's right to development, and dictated, to a large extent, the UN Committee on the Rights of the Child's interpretation of this right.

The justifications and practical implications of recognising children's agency have been previously discussed in this chapter and in the Introduction of the thesis.But in the context of the Capability Approach, particular attention should be given to children's right to participation in shaping their future. If children articulate their view concerning their own freedom, it will break the dichotomous distinction between the 'human becomings' and 'human beings' conceptions. Comim claims that in the context of the Capability Approach,

\footnotetext{
${ }^{111}$ See Dixon and Nussbaum's discussion about people with disabilities and US constitutional law. Dixon and Nussbaum, supra n. 60, 585-586.
} 
children usually 'are not consulted in the meaning of an active actor in society, ${ }^{112}$ thought this sort of treatment ignores the fact that 'children would probably define the meaning of being an active actor or citizen differently'. ${ }^{113}$ While Comim flags this latter point as a potential argument against realizing children's participation, I argue that this argument is in fact an excellent example why children should participate. Their unique point of view is the reason for giving children a voice, rather than a reason to continue to silence them.

Adopting the view that children, even toddlers, can and should express their preferences enables us to overcome the main barrier for implementing the Capability Approachin analysing the child's right to development. Adopting a more progressive view about childhood and children's capacities, like Korczak's approach was suggesting, can lead to the conclusion than children should play an active role in realizing their self-determination, and express their preference about their own future. Saito is alarmed by this kind of suggestion, and warns us that

'giving temporary freedom to a child does not always mean that the child will have freedom in future, and similarly, restricting the temporary freedom of a child may well expend the freedom that the child will have in the future. We, therefore, have to consider the freedom for a child in a lifelong perspective'. ${ }^{114}$

This concern for the child's future is well-placed. However, one should not disregard or underminethe value of the child's life in the present, and its manifestation in the right to participation. The unconditional preference for safeguarding the child's future undermines the recognition of children as rights holders, depriving them of agency and voice. It is based on an assumption that sacrificing children's freedom now will lead to a greater freedom in the future, once the child becomes an adult. As Dixon and Nussbaum claim: 'we ought to support capabilities that will best promote a long-term future of full capabilities'. ${ }^{115}$ Ensuring freedoms in the future should not justify denying all freedoms in the present; rather, the contrary is true. Arguably, ensuring freedoms in the present will enable children to fulfil their potential and pursue lives worth living in the future. For this reason, children's voices and opinions should not be silenced or dismissed, but rather amplified.

\footnotetext{
${ }^{112}$ Comim et al, supra n. 59, 7.

${ }^{113}$ Ibid.

${ }^{114}$ Saito, supra n. 1, 26.

${ }^{115}$ Dixon and Nussbaum, supra n. 60, 555.
} 


\section{Utilising the Capability Approach to Concretise 'Children's Development'}

The second contribution of the Capability Approach to the analysis of the child's right to development is its contribution to concretising the term 'children's development'. In light of the idea of development as freedom, we saw that Nussbaum has suggested a list of ten capabilities (life, bodily health, bodily integrity, sense, imagination and thought, emotions, practical reasons, affiliation, play and control over one's environment), which she deemed as a minimum universal that are necessary in to be free. According to Vizard, these basic capabilitiescan be seenas grounds for a 'human rights based capability framework', ${ }^{116}$ mainly because they resemble the basic universal rights that are protected by the HDHR and 1966 Covenants as universal human rights. ${ }^{117}$

This list of capabilities is relevant for children for two reasons. First, it meets their needs and cannot be challenged on the basis of a pre-requirement for capacities. Second, many of these capabilities are already defined as children's human rights by the Convention, ${ }^{118}$ which means that their universal acceptance has already been established (if only by the almost universal ratification of the Convention). Therefore, taking the Capability Approach's perspective, these rights can be understood as substantial to the realisation of the child's right to development. Although at first glance this list of rights might resemble the Committee on the Rights of the Child's jurisprudence, in the context of the Capability Approach these rights serve a different purpose. Here, these capabilities - and the corresponding rights -support the child's freedom, while for the Committee these rights are needed in order to enable the child to become an adult.

Mario Biggeri and Santosh Mehrotra suggest a different list of capabilities, which they deem as even more relevant to children. Their list has fourteen capabilities: life and physical health; love and care; mental well-being; bodily integrity and safety; social relations; participation; education; freedom from economic and non-economic exploitation; shelter and environment; leisure activities; respect; religion and identity; time autonomy; and mobility. ${ }^{119}$ In similarity to Nussbaum's list, most of the capabilities in this list, nine to be exact, can be conceptualised in terms of children's rights under the Convention (Articles 6, 24, 12, 28, 29, 32, 27, 31, 14,

\footnotetext{
${ }^{116}$ Vizard, supra n. 108, 234-235.

${ }^{117}$ Ibid.

118 The convention protects the child's right to life, the right to health, bodily integrity, affiliations, and right to play in Articles 6, 24, 19, 7, 8, 9, 11 and 31, respectively.

${ }^{119}$ Mario Biggeri and Santosh Mehrotra, 'Child Poverty as Capability Deprivation: How to Choose Domains of Child Well-being and Poverty', In Mario Biggeri et al (eds) Children and the Capability Approach, supra n. 59, $46-75,51$.
} 
30, 7 and 8, respectively). The remaining capabilities, such as love and care, social relationship and respect, are not considered as rights of the child under the Convention, since these issues are traditionally issues seen as beyond the power of law to regulate (Thoughit was suggested that children do have the right to be loved, and the right to 'time autonomy'). ${ }^{120}$ Biggeri and Mehrotra further claim that using the Capability Approachas a 'framework for normative evaluation and policy implementation ${ }^{121}$ with regard to children provides normative and positive grounds for promoting these capabilities. Looking at this list from the perspective of the right to development and by employing the Capability Approach'sterminology, it can be argued that realizing these rights means providing the necessary capabilities for the child to be free.

\section{$\underline{\text { Conclusion }}$}

I discussthe question of whether the Capability Approach can contribute to the analysis of the child' right to developmenton the affirmative. Children, like adults, should be able to live lives worth living. The departure point this discussion should be conceptualising children as active agents in shaping their own life, and respecting that they value different functions and utilise different capabilities than adults do. Incorporating the Capability Approach's understanding of development into the framework of child's right to development can help expand the meanings of 'development' beyond the psycho-social conception and the child's right to development beyond the right to become an adult. The Capability Approach also suggests how this idea of 'human development' could be realised in reality, delineating what the necessary capabilities are.

I have reviewed two sets of capabilities, withonly one of them formulated explicitly with the intention to meet children's needs. These lists show that 'children's development' can be translated into human rights terms, but a more contextualized list should be further developed in order to fit to different children in different circumstances. The suggested capabilities can later be articulated in human rights terms, using the universal credibility of the Convention as a positive source.

\footnotetext{
${ }^{120}$ See chapter one.

121 Mario Biggeri et al, 'Children's Agency and the Capability Approach: A Conceptual Framework', In Mario Biggeri et al (eds) Children and the Capability Approach, supra n. 59, 39-40.
} 


\section{Measuring Capabilities - the Human Development Report}

Measuring capabilities is a challenging task. It requires having a conceptual clarity of what human development stands for, what is it composed of, and only then the relevant factors and variable that can measure 'development' can be identified. The two lists of capabilities mentioned before are two examples of efforts to concretise human development. But these lists still require further development so they can be operational, certainly with respect to children.

Measuring capabilities not only reflects a certain conception of human development, but it can also give an indication about the status of 'human development' in a given geographic location, or of a specific segment of the population. These indications can inform decision and policy maker about their success and failures to promote human development. This section presents the UN Development Program's 'Human Development Report' (HDR), which has been published annually since 1990. The HDR is the most ample effort to concretise and measure 'human development'. I argue that the complexity of the HDR signifies the feasibility to concretise what children's right to development stands for.

The HDR, which includes the Human Development Index, employs an economic critical point of view andexplores 'the relationship between economic growth and human development'. ${ }^{122}$ As such, it corresponds to the Capability Approach, adopting and adapting most of the Capability Approach conceptions of 'human development'. Similarly to the Capability Approach, the HDR takes the view that 'income is not the total sum of human life ${ }^{123}$ and, therefore, conceptualises 'the real objective of development' as 'enlarging people's options' ${ }^{124}$ The Human Development Index that follows is a comparison tool that measures key capabilities by relative levels in every country. Nevertheless, as the first HDR acknowledges, this index only captures 'a few of people's choices and leaves out many that people may value highly'. ${ }^{125}$ According to Mahbub ul Haq, thecreator of the HDR, 'the objective of development is to create an enabling environment for people to enjoy long, healthy and creative lives'. ${ }^{126}$ Ul Haq explains this approach in similar terms to those employed by Nussbaum and Sen, saying that development is more than economic well-being,

\footnotetext{
${ }^{122}$ Mahbub ul Haq, Reflections on Human Development (Oxford University Press, Oxford 1995) 26.

${ }^{123}$ UNDP, Human Development Report 1990 (Oxford University Press, New York 1990) 9.

${ }^{124}$ Ibid, 25.

125 Ibid, 16.

${ }^{126}$ Ul Haq, supra n. 122, 14.
} 
and includes 'knowledge, health, a clean physical environment, political freedom and a simple pleasures of life'. ${ }^{127} \mathrm{He}$ further adds that

'It is fair to say that the human development paradigm is the most holistic development model that exists today. It embraces every developmental issue, including economic growth, social investment, people's empowerment, provision of basic needs and social safety nets, political and cultural freedom and all other aspects of people's lives. It is neither narrowly technocratic not overly philosophical. It is a practical reflection of life itself., ${ }^{128}$

The question is whether ul Haq indeed succeeded in providing a coherent and meaningful interpretation of what he defines as a 'holistic' concept of development. The first HDR states that the index

'emphasizes the development of human choices... it is reflected in measuring development not as the expansion of commodities and wealth, but as the widening of human choices'. ${ }^{129}$

Consistent with the Capability Approach, the HDR, therefore, defines the essential components of development as equity, sustainability, productivity, and empowerment. ${ }^{130}$ Accordingly, it defines threeelements of human development: people to be placedat the centre of attention, as both a means and end of development; 'development' is a process of forming human capabilities and enabling people to acquire them; economy is not the only segment that drives development forward. ${ }^{131}$ Subsequently, the index measures human development according to three key components: longevity (life expectancy at birth), knowledge (adult literacy and years of schooling) and income (defined as 'up to the cut-off point as having full value... the premises is that people do not need an infinite amount of income for a decent life'). ${ }^{132}$

While this perception of human development seems to be broad and comprehensive, the index measures only a fraction of human's life experiences. The index was also criticized for being 'conceptually weak and empirically unsound, involving ... measurement errors and

\footnotetext{
${ }^{127}$ Ibid, 14-15.

${ }^{128}$ Ibid, 23.

${ }^{129}$ UNDP, Human Development Report 1990, supra n. 123, 1.

${ }^{130} \mathrm{Ul}$ Haq, supra n. $122,16-20$.

${ }^{131}$ Ibid, 16.

${ }^{132}$ UNDP, Human Development Report 1990, supra n. 123, 49.
} 
biases' ${ }^{133}$ Another weakness of the index, according to Anands and Sen, is the 'problematic' and ambiguous quantification of human development it upholds. ${ }^{134}$ These measurement errors, according to Mark McGillivray and Howard White, undermine its ambitionto provide a comparative tool to evaluate development. ${ }^{135}$ Proponents of liberal-market approaches claim that both the HDR and the index misunderstand the importance of growth and its impact, ${ }^{136}$ and fail to measure human development because the selection of functionings they measure. ${ }^{137}$ Claims have also been made concerning the index's lack of cultural and social sensitivity. ${ }^{138}$ A critical approach that follows Arturo Escobar ${ }^{139}$ accused the HDR for posing as natural and value-free, but nevertheless carrying ideological baggage, making itculturally biased. Ambuj Sagar and Adil Najam went as far as claiming that the index has lost touch with the world it is attempting to portray. ${ }^{140}$ Likewise, Amanda Perry-Kessaris recently claimed that the HDR's indictors are a new form of 'economics imperialism' ${ }^{141}$

Arguably, the HDR is also age-biased. While the index contains some variables that relate to children, such as primary school enrolment rates, children or children's development is not explicitlyreferred to as a distinct category in either the HDR or the index. Even 'general' issues, such as poverty, do not address children's unique position in the economic order. Overlooking children is further evident by another example: Each of the HDR's published in the last twenty years were dedicated to a specific issue, such as power and poverty (2006), gender (1995), human security (1994) or participation (1993), but none of the reports were dedicated to children.

One HDR that is worth paying attention to in this context is the Human Rights and Human Development report from $2000 .{ }^{142}$ This report mirrors the human rights approach to

\footnotetext{
${ }^{133}$ Thirukodikaval Nilakanta Srinivasan, 'Human Development: A New Paradigm or Reinvention of the Wheel?' (1994) 84 AEA Papers and Proceedings 238, 241.

${ }^{134}$ Sodhir Anands and Amartya Sen, 'The Income Component of the Human Development Index' (2000) 1 Journal of Human Development 83, 99.

${ }^{135}$ Mark McGillivray and Howard White, 'Measuring Development? The UNDP's Human Development Index' (1993) 5 Journal of International Development 183.

${ }^{136}$ Martin Ravallion, 'Good and Bad Growth: The Human Development Reports' (1997) World Development 631, 637.

${ }^{137}$ Saito, supra n. 1, 22.

${ }^{138}$ Ibid, 23.

${ }^{139}$ Escobar, supra n. 8.

${ }^{140}$ Ambuj D. Sagar and Adil Najam, ‘The Human Development Index: A Critical Review' (1998) 25 Ecological Economy 249.

${ }^{141}$ Amanda Perry-Kessaris, 'Prepare Your Indicators: Economic Imperialism on the Shores of Law and Development' (2011) 7 International Journal of Law in Context 401.

${ }^{142}$ UNDP, Human Development Report - Human Rights and Human Development (Oxford University Press, Oxford and New York 2000).
} 
development, ${ }^{143}$ stating that 'the divide between the human development agenda and the human rights agenda is narrowing'. ${ }^{144}$ The report asserts that human rights provides a framework of accountability for the human development paradigm and that human development is essential for realizing human rights, and human rights are essential for full human development'. ${ }^{145}$ This statement aligned with Senguptak's approach to the right to development, which emphasises the role of human rights in realizing human development. This statement is also an answer to those, like Biggeri et al, who cast doubts regarding the contribution and usability of human rights in promoting human development.

Nonetheless, this Report includes the same few indicators concerning children as the previous reports, but neither children's development nor children's right to development receive significant attention. Children were once again left at the margins of this Report and are mentioned only twice. The first instance is in a table titled 'realizing the right to primary education in India' ${ }^{146}$ and the second is in a section titled 'the rights of the child - turning words into actions'. ${ }^{147}$ These two references offerlittle substance concerning the rights of children. More troubling is that children are not viewed as subjects of rights or as active members of society.

To conclude, The HDR is an example for concretizing a theoretical conception of human development in human rights terms. Although variables concerning children's development are not part of the HDR or the index, the HDR does have a limited potential for telling us which rights of children need to be protected in order to support children's development. For example, the HDR informs us about the connection between school enrolment as an indicator for protection and promotion of the right to education and the right to non-discrimination. But because the HDR is more concerned with children's futures and children's lives during their childhoods are rarely addressed, its contribution is as limited as any of the other instruments that employ the 'human becomings' conception of childhood. The HDR is a perfect example

\footnotetext{
143 Andre Cornwall and Celestine Nyamu-Musembi, 'Putting the 'Rights-Based Approach' to Development into Practice' (2004) 25 Third World Quarterly 1415, 1420; Sengupta, 'The Human Right to Development', supra n. 27, 181;Urban Jonsson, 'A Human Rights-Based Approach to Programming' in Paul Gready and Jonathan Ensor (eds) Reinventing Development? (Zed Books, London 2005), 47-62, 47; Robert Archer, 'The Strengths of Different Traditions: What Can Be Gained and What Might Be Lost By Combining Rights and Development?' (2006) 4 The International Journal of Human Rights 81; Mary Robinson, 'What Rights Can Add to Good Development Practices?' in Philip Alston and Mary Robinson (eds) Human Rights and Development (Oxford University Press, Oxford 2005) 25-41.

${ }^{144}$ UNDP, Human Development Report - Human Rights and Human Development, supra n. 142,2.

${ }^{145}$ Ibid, 2.

${ }^{146}$ Ibid, 104

${ }^{147}$ Ibid, 116.
} 
to how exclusion of children from theory leads to their exclusion from practice. A better placed to concretise children's development and the child's right to development is an index that focuses on children.

\section{ConcretisingChildren's 'Development' - The Child Indicators Movement}

This section studies how the child indicator movement conceptualises 'children's development' and 'children's well-being' and fragments these concepts. I argue that these indexes further show that 'children's development' should not be seen only as an abstract concept, but rather as a concrete concept that can, and should, be articulated in human rights terms.

The Child's Indicators Movement, a title describing a range of projects that attempt to measure children's development and children's well-being, dates back to the 1920 's. ${ }^{148}$ Since these two concepts - development and well-being - are used conjointly, conclusion about the child's right to development should be drawn with caution. Today,the movement consists of a large number of indices that gather information from local, regional, national or international levels, concerning various segments of the child's life, including education, health, contact with peer-groups, family environment, etc. ${ }^{149}$

The conception of children's development employed by the movement has changed over time, mainly due to changes in the perception of childhood. The early child indicators indices perceived children as 'human becomings', and consequently, children's development and children's well-being were measured on the basis of negative factors, such as mortality rate, in order to try topredict children's life expectancies, and future prospects as adults. The emergence of the 'human beings' paradigm, the normative influence of the Convention on the Rights of the Child, and the emergence of new theories of children's development changed the ways in which childhood was conceived and, consequently, how children's development and well-being were measured. ${ }^{150}$ These changes are reflected in the increasing numbers of variables being measured, and the subsequent creation of more complex indices. The new

\footnotetext{
${ }^{148}$ Asher Ben-Arieh, 'The Child Indicators Movement: Past, Present, and Future' (2008) 1 Child Indicator Research 3, 3. Laura H. Lippman, 'Indicators and Indices of Child Well-Being: A Brief American History' (2007) 83 Social Indicators Research 39.

149 Lippman, Ibid, 46-47.

${ }^{150}$ Ben-Arieh, 'The Child Indicators Movement: Past, Present, and Future', supra n. 148.
} 
indices include indicators such as school attendance and dropout rates ${ }^{151}$ (similar to the Human Development Index), children's 'health, socioemotinal status and functioning, moral and ethical attitudes and behaviour, intellectual status and functioning, and other capacities, such as music, art, mechanical and athletic'. ${ }^{152}$ Most recent indices also factor in children's own perspectives on their life. ${ }^{153}$ The importance of the latter cannot be overstated. As claimed earlier, asking children for their perspective respects children's agency, and adds an important and often overlooked factor, which is children's experiencesand perspectives on their own lives.

In recent years, a new goal for the movement was established, and children's quality of life is being measured, alongside their development and well-being (thus suggesting that these concepts have different meanings). According to Asher Ben Arieh, children's quality of liferelates to the 'future success of the generation' in a child-centred oriented approach.Consequently, children's civic skills, ${ }^{154}$ for example, are being measured as well. Nevertheless, Anne-Marie Etienne et alassert that these assessments of children's quality of life still conceptualise children only as 'subject[s] who are constantly changing and developing, ${ }^{155}$ thus undermining the claims of a paradigm shift in the way that this movement conceptualises childhood and children's development.This line of critique reflects the tendency to conceptualise childhood in a polarised way, demanding researchers to choose between one dichotomy or the other - between the 'human becomings' and the 'human beings' approach.

UNICEF's State of the World's Children is considered the flagship of the movement. It was first published in 1980, ${ }^{156}$ a decade before the Human Development Reports. The early State of the World's Children reports reflect the narrow 'human development' idea of the time, before the Capability Approach revolution, and measure what UNICEF believed to influence children's poverty. The first report included, for example, statistical data on maternal illhealth and malnutrition, rates of breastfeeding, family planning, children's disability (including the cost of preventing disabilities and treating children with disabilities),

\footnotetext{
151 Ibid.

${ }^{152}$ Lippman, 'Indicators and Indices of Child Well-Being: A Brief American History', supra n. 148, 43.

${ }^{153}$ Ben-Arieh, 'The Child Indicators Movement: Past, Present, and Future', supra n. 148. See Lippman, Ibid, 46. See also Kristin Anderson Moore and Laura H. Lippman, What Do Children Need to Flourish? (Springer, New York 2005).

154 Ben-Arieh, 'The Child Indicators Movement: Past, Present, and Future', supra n. 148, 12.

${ }^{155}$ Anne-Marie Etienne et al., 'The Gap Concept as a Quality of Life Measure: Validation Study of the Child Quality of Life Systemic Inventory' (2011) 100 Social Indicators Research 241, 242.

${ }^{156}$ James P. Grant for UNICEF, The State of the World's Children 1980-1981 (UNICEF, New York 1981).
} 
prevention of diseases caused by malnutrition, personal hygiene, lack of access to clean water, health education, safe sanitation and immunization, and food security. ${ }^{157}$ In time, the State of the World Childrenreport expanded the range of indicators it measured. But unfortunately, as the latest report from 2011 shows, ${ }^{158}$ its perception of children's development and well-being has not changed significantly. Even today, most, if not all of the indices are negative ones, expressing concern for issues that relate to children's survival rather than their development, well-being or quality of life. This index is a perfect representation of the dominance of the 'human becomings' paradigm. The indicators it uses conceive children as passive recipients of welfare, ignoring children's agency, perspectives and rights. As the most important index of the movement, it casts shadow on other, much more progressive, effort to measure children's development.

Some recent indices had more success where UNICEF has failed. These indices provide comprehensive conceptions of children's development, well-being and quality of life. Ken Land's index is one of the first indices to meet these challenges. ${ }^{159}$ According to Land, children's quality of life includes 'objective and subjective axes of human existence'. ${ }^{160} \mathrm{He}$ divides children's quality of life seven domains: material well-being; social relationship; health; safety/behavioural concerns; productive activity (educational attainments); place in community (participation in schooling or work institutions); and emotional/spiritual wellbeing. Twenty-eight indicators measure these domains: ${ }^{161}$ poverty rate; secure parental employment rate, median annual income; rate of children with health insurance; infant mortality rate; low birth weight rate; mortality rate (ages 1-19); rate of children with very good or excellent health; rate of children with activity limitations (as reported by parents); rate of overweight children and adolescents (ages 6-19); teenage birth rate (ages 10-17); rate of violent crime victimization (ages 12-19); rate of crime offenders (ages 12-17); rate of cigarette smokers; rate of alcohol drinking; rate of illicit drug use; reading test scores (ages 9, 13 and 17); mathematics test scores (ages 9, 13 and 17); rate of persons who have received a high school diploma (ages 18-24); rate of youth not working and not in school (ages 16-19); rate of pre-kindergarten enrolment (ages 3-4); rate of persons who have received a bachelor's

\footnotetext{
${ }^{157}$ Ibid.

${ }^{158}$ UNICEF, The State of The World's Children 2011 (UNICEF, New York 2011).

${ }^{159}$ Kenneth C. Land et al, 'Child and Youth Well-Being in the United States, 1975-1998: Some Findings from a New Index' (2001) 56 Social Indicators Research 241. See also Lippman, 'Indicators and Indices of Child Well-Being: A Brief American History' supra n. 148, 47.

${ }^{160}$ Land et al, ibid, 244.

${ }^{161}$ Land et al, ibid, 243.
} 
degree (ages 25-29); rate of voting in presidential elections (ages 18-20); rate of children in families headed by a single parent; rate of children who have moved within the last year (age 1-18); suicide rate (age 10-19); rate of weekly religious attendance; and per cent of children who report religion as being very important.

The index provides a comprehensive breakdown of various elements of children's lives, which compose a detailed directory for children's development, well-being and quality of life. ${ }^{162}$ The index encompasses variants related to many aspects of children's lives and different spaces of activities and social interactions. It encompasses children's lives as children, and not only as future adults, alongside factors that influence their future. In that sense, it accommodates both the 'human beings' and 'human becomings' conceptions of childhood. Furthermore, although the index was created before the UN Committee on the Rights of the Child became operational, and even before the final text of the Convention was adopted, it is much broader and more complex than the UN Committee's catalogue on children's development. ${ }^{163}$ The index is also broader and more comprehensive than the Human Development Index, and it appears to succeed where that index has failed, in providing a holistic concept of children's development. It is rather easy to rule out those factors that are not related to children (according to Article 1 of the Convention's definition of children as a person under the age of 18), such as the percentage of people holding bachelor's degrees. However, it is more difficult to distinguish between development, wellbeing and quality of life. A separate question is whether these three concepts are in fact different.

While most of its indictors can be articulated in human rights terms, some cannot. For example, while most variables that relate to health and education can be seen as covered by the rights to health and education, it is more difficult to articulate the rate of children who have moved within the last year to human rights issues, since moving houses is not a human rights violation, per se. Furthermore, the index is USA-centric and reflects conservative middle-class values and life style (for example, when it measures children's obesity, alcohol and drug consumption, and weekly religious attendance). As such, using its indicators in other contexts may generate a distorted picture concerning the state of children's

\footnotetext{
${ }^{162}$ See also the Index of Social Health, first published in the USA in 1987. This index addressed the ways in which social problems interact to create a social climate, instead of focusing on individual problems themselves'. The list of indicators is much longer than Land's list, and it included 'infant mortality, child abuse, children in poverty; and for youth, teen suicide, drug abuse, and high school drop-outs'. Lippman, 'Indicators and Indices of Child Well-Being: A Brief American History' supra n. 148, 46.

${ }^{163}$ See chapter three.
} 
development, well-being and quality of life. Nonetheless, from the perspective of protecting children's rights in general, and their right to development in particular, this index can be proved useful in the effort to concretise children's development in human rights terms.

As a response to Lands' project, Kristin Moore et al developed an even more comprehensive and complex index. Moore et al have tried to overcome some of the methodological and conceptual shortcomings of Land's work, as well as those of other similarly USA-focused indices'. ${ }^{164}$ They stated that their aim was to:

'truly measure well-being, as opposed to documenting the prevalence of risks, and to do so comprehensively by using a conceptual framework based on developmental theory, which specifies multiple levels of functioning at the individual level (physical, cognitive/educational, social, and psychological) and multiple contexts of influence (sociodemographic, family and community) that might promote or constrain development'. ${ }^{165}$

Accordingly, the index addresses children's social links and conditions in a way consistent with 'developmental theory that typically considers four key domains of development: physical, intellectual/educational, psychological, and social and embeds individuals in a system of ecological influence. ${ }^{166}$ It is worth noting that they refer to only one theory of developmental psychology, ignoring the existence of range of theories.

The index includes four domains for measuring children's well-being: physical, psychological, social and educational/intellectual, which are measured in three contexts: family, neighbourhood and socio demographic. The index contains 69 variants, ${ }^{167}$ two and a half times more than Land's index. This index is a meaningful step forward in concretising the development in the child's right to development' and, as with Land's index, can be formulated, to some extent, in terms of the Convention's rights. Nonetheless, and despite its aims, the index suffers from similar deficiencies as Land's index does. It perceives children as passive actors and as recipients of welfare policies and does not accommodate any participatory methods. This index is also culturally biased, reflecting similar Western, middle-class, conservative values and liberal market ideology. It also employs mainstream developmental psychology's theories, and therefore, does not fit all children and can not

\footnotetext{
${ }^{164}$ Kristin A. Moore et al, 'A Microdata Child Well-Being Index: Conceptualization, Creation and Findings' (2008) 1 ChildIndicator Research 17.

${ }^{165}$ Ibid, 41 .

${ }^{166}$ Ibid, 24.

${ }^{167}$ Ibid, 45-48.
} 
comprehend their different experiences of childhood, and thus, their different experiences and wishes from their own development.

Having said that, this line of critique is also the reason why this index is comparable to the Convention, particularly to the Convention's conception of children's development. Ashwani Saith and Rekha Wazir criticised this index, as well as others that employ similar perspectives, arguing that while these indices can be valid in developed countries (and thus accurately reflect the state of children's lives there) if used in less developed countries, these indicators will present a distorted picture of children's lives. ${ }^{168}$ Saith and Wazir further argue, in similarity to Sagar and Najam's critique on the Human Development index, that there is a need to develop local indexes that can accommodate a holistic nature of child well-being within the context of less developed countries. ${ }^{169}$ As novel as this wish sounds, experience showsthat reaching such a national consensus is not an easy task, as the recent effort of the Republic of Ireland shows, since it involves contested values that need to be mediated. ${ }^{170}$

Many other indices are available, and they will not be reviewed here. The high volume of indices exemplifies the lack of a unified taxonomy for measuring children's development and well-being, ${ }^{171}$ and also shows that there is more than one way to conceptualise children's development. In light of this diversity, Ivar Frønesand Asher Ben-Arieh have recently suggested using the Capability Approach as a common language. ${ }^{172}$

'The concept of capabilities is especially suited related to children's wellbeing because children's movement through life produces new contexts, assigning new values to resources and commodities...the fact that capabilities influences well-being illustrates the significant of the approach. Yet we are not suggesting a set of indicators on capabilities; rather we call for the positioning of well-being within the framework of the capabilities approach, underlining the differences and dynamic relationships - between capabilities and outcomes. 173

\footnotetext{
${ }^{168}$ Ashwani Saith and Rekha Wazir, 'Towards Conceptualizing Child Well-being in India: The Need for a Paradigm Shift' (2010) 3 Children Indication Research 385.

${ }^{169}$ Ibid.

${ }^{170}$ Sinéad Hanafin et al, 'Achieving Consensus in Developing a National Set of Child Well-Being Indicators' (2007) 80 Social Indicators Research 79. See also John Pinkerton, 'Children's Participation in the Policy Process: Some Thoughts on Policy Evaluation Based on the Irish National Children's Strategy' (2004) 18 Children \& Society 119. But see a more positive experiences in Australia and the EU: Ann V. Sanson et al, 'The Development and Validation of Australian Indices of Child Development - Part I: Conceptualisation and Development' (2010) 3 Children Indication Research 275, 290; Jonathan Bradshaw and Dominic Richardson, 'An Index of Child Well-Being in Europe' (2009) 2 Children Indication Research 319.

${ }^{171}$ Asher Ben-Arieh and Ivar Frønes, 'Taxonomy for Child Well-Being Indicators: A Framework for the Analysis of the Well-Being of Children' (2011) 18 Childhood 460.

${ }^{172}$ Ibid, 464.

${ }^{173}$ Ibid, 464.
} 
Frønes and Ben-Arieh concentrate on the child's present and future well-being (and not necessarily development), ${ }^{174}$ and ask to conceptualise children's lives according to 'the developmental relationship between today and tomorrow; [since] the conditions of the present influences further development'. ${ }^{175}$ At first glance this approach may seem appealing, not only because it rejects the 'human becomings' model, but primarily because it also rejects polarized views about childhood. Nonetheless, this suggestion is not significantly different from previous approaches. On the one hand, this suggestion employs a similar rhetoric concerning childhood, children and well-being, which according to Ben-Arieh himself, was used $^{176}$ and allegedly asks to remedy their faults. Therefore, Frønes and Ben-Arieh do not present new indices, or provide more concrete or practical tools for understanding children's well-being and development. On the other hand, this approach does pointtothe need to be context-sensitive in relation to the child's social and economic environments, as well as to the individual child. This approach recognises diversity among children, even if only according to their age (a division that reflects Western conception of childhood and developmental psychology models of childhood). ${ }^{177}$ Therefore, such a new taxonomy can contribute to the realisation that children are not a homogenous group, and subsequently neither their 'development', nor the meaning of their 'right to development' is homogenous as well.

A major flaw of most of the early indices is that they perceive children as passive and fail to recognise their agency. In recent years, new indices have been created to remedy this problem, ${ }^{178}$ and they accommodate children's views. ${ }^{179}$ Children's participation is respected because it is 'the only way to grasp how they [children] perceive differences within their local contexts, both between groups of children and between children and adults'. 180 Employing the method of participation leads to 'a child focused approach [that]

\footnotetext{
${ }^{174}$ Ibid, 474.

${ }^{175}$ Ibid, 463.

${ }^{176}$ Ben-Arieh, 'The Child Indicators Movement: Past, Present, and Future', supra n. 148.

177 Allison James et al, Theorizing Childhood (Polity Press, Cambridge 1998) 60-61.

${ }^{178}$ Ferran Casas, 'Children's Rights and Children's Quality of Life: Conceptual and Practical Issues' (1997) Social Indicators Research 283, 287-288.

${ }^{179}$ Asher Ben-Arieh, 'Where Are the Children? Children's Role in Measuring and Monitoring Their WellBeing' (2005) 74 Social Indicators Research 573, 574-579. According to Ben-Arieh, children can take part in research not only as sources of information, but also to participate at the study design, to be the date collectors, to take part at the date analysis or to take part in utilising the data. 580-586.

${ }^{180}$ Gina Crivello et al, 'How Can Children Tell Us About Their Wellbeing? Exploring the Potential of Participatory Research Approaches within Young Lives' (2009) 90 Social Indicators Research 51, 54.
} 
acknowledges that children are diverse in their capacities for resilience'. ${ }^{181}$ Participatory methods allow children to have active roles in research concerning them and subsequently, the policy that is formulated on the basis of these surveys that affect their lives.

One example of a participatory project is Young lives. Young lives is a study concerning the effects of poverty on children's lives, with the goal of understanding how children experience living in poverty and how poverty shapes their future. ${ }^{182}$ In that sense, the project focuses on one dimension of children's life, echoing pre-Capability Approach conception of development. The project accommodates tensions between universality and contextualization, aiming to

'improve existing indicators, to develop methods and methodologies appropriate to data collection with children in general, to develop methodologies to fully understand the situation of children... and to develop means of information sharing that will result in more holistic and integrated information about children'. ${ }^{183}$

Young Life, therefore, is not fixed with a certain, predefined concept of well-being, but rather modifies the definition based on the input received from children themselves. ${ }^{184}$ Thus far, the study shows four key findings. The first is concerned with the negative effect of undernutrition in several domains of children's development, including physical growth and cognitive development. The second highlights the connection between different competencies and skills and children's learning and development. The third centres on the persistence of poverty and inequality (i.e chronic poverty), showing that economic growth does not necessarily trickle down, and that some children remain 'trapped in poverty'. The fourth is the relationship between poverty and other forms of risks. ${ }^{185}$ These findings can contribute to an understanding of how children interpret their lives and the world that surrounds them.

Allof these indices measure different components of what presumably composes children's well-being, quality of life and development. They provide empirical data, which is based on different preliminary assumptions concerning the meaning of this term, as well as the meaning of childhood. Despite claims of paradigm shifting, and in congruence with the

\footnotetext{
${ }^{181}$ Ibid.

${ }^{182}$ See the collection of article dedicated to the Young Life project. Jo Boyden and Michael Bourdillon (eds) Childhood Poverty - Multidisciplinary Approach (Palgrave Macmillan, Basingstoke 2012).

${ }^{183}$ Casas, supra n. 178, 291.

${ }^{184}$ Ibid.

${ }^{185}$ Michael Bourdillon, 'Introduction' in Jo Boyden and Michael Bourdillon (eds) Childhood Poverty Multidisciplinary Approach, supra n. 182, 1-12, 6-8.
} 
Convention or the Committee's jurisprudence, the paramount conception of childhood is still 'human becomings'. This conception not only dictates what variables these indices measure, but also how they are being measured. Mainly, it excludes children from actively participating in these studies.

Not all the indicators can be articulated in the Convention's human rights terms, but most of them,especially those related to education, health, working environment and family relationships, can certainly be. Consequently, the indices are utilized in analysing the child's right to development.

\section{Conclusion}

The chapter presented two conceptions of 'human development', one according to the general right to development and one according to the Capability Approach. Both concepts are different from the concept of 'children's development' that is currently employed in international children's rights law. I suggest that employing key components of these instruments, mainly the distinctions between the process of development and the outcome of it; the significance of respecting people's agency; and the conceptualisation of development as freedom, in a framework that analyses the child's right to development, will enable to broaden the meaning of the right beyond its current limited interpretation. The welldeveloped Capability Approach has also demonstrated what capabilities are necessary to support 'human development' and, in turn, how these capabilities can be articulated in human rights terms. A comprehensive, let alone conclusive list of capabilities, which can be more relevant to children's development, is not yet available.

The various indices measuring children's development, well-being and quality of life have shown that 'children's development' should not be deemed to be a vague concept, nor should it be bound by mainstream developmental psychology. The indices demonstrate that 'children's development' can be understood in broader terms, which can later be translated into measurable fragmentations and articulated in human rights terms. In other words, the indexes show that the promotion of particular human rights of children, such as the right to education, the right to health or the right to non-discrimination, can promote the child's human development. The question that remains unanswered is what is the added value of the child's right to development over respecting other numerated rights? Phrased differently, is the child's right to development only a summation of other rights? The next chapter addresses this question. 


\section{Chapter Six: A New Framework To Analyse The Child's Right To}

\section{Development}

'States Parties shall ensure to the maximum extent possible the survival and development of the child' (Article 6(2), UN Convention on the Rights of the Child)

\section{$\underline{\text { Introduction }}$}

Thischapter offers a new framework for analysing the child's right to development. The framework is situated within theUN Convention on the Rights of the Child's broad protection for children's development and the Convention's ethical perspective. ${ }^{1}$ This framework adopts an interdisciplinary approach to the analysis of the child's legal right to development, ${ }^{2}$ and perceives 'children's development' as an issue of human rights and not of welfare or salvation. It incorporates a hybrid conception of childhood, promotes further respect for children's agency, and draws a clearer distinction between the right to development's meaning as a guiding principle of the Convention and its meaning as a distinct human right. Using this framework in conjunction with a cross-disciplinary understanding of the term 'children's development' will enable creating a comprehensive and concrete interpretation of the child's right to development.

The chapter has four sections. The first section contextualises the discussion about the child's right to development within the framework of the UN Convention on the Rights of the Child,and highlights shortcomings in the current approach and interpretation of this right. The second section suggests a road map for remedying these shortcomings. It includes adopting a conception of childhood that synthesises the 'human beings' and 'human becomings' approaches to childhood,utilising the Capability Approach as an additional dimension of children's development, and re-defining the aim of the right to development accordingly. In accordance with these key themes, the third section presents a new framework for the analysis of the child's right to development. The last sectiondiscusses the practicality of the suggested framework, highlights questions that remain unanswered and suggests avenues for future research.

\footnotetext{
${ }^{1}$ With respect to the Convention's ethical perspective see John Wall, Ethics in Light of Childhood (Georgetown University Press, Washington DC 2010) 113-138.

${ }^{2}$ Compare with Adrian James, 'Competition or Integration? The Next Step in Childhood Studies?' (2010) 17 Childhood 485; Priscilla Alderson, 'Young Children's Human Rights: A Sociological Analysis' (2012) 20 International Journal of Children's Rights 177; Michael Freeman, 'Towards a Sociology of Children's Rights' in Michael Freeman (ed) Law and Childhood Studies (Oxford University Press, Oxford 2012) 29-38.
} 


\section{Contextualising the Discussion: Children's Rights and Children's Development}

This section contextualises the discussion about the child's right to development within the frameworks of childhood studies, children's rights theory and the UN Convention on the Rights of the Child's ethical perspective. Based on chapters one-four, I draw a picture of how the child's right to development is perceived in international children's rights law today, and what the main limitations of this approach are.

Article 6(2) of the UN Convention on the Rights of the Child protects the child's right to development. In addition, five other articles(Articles 18(1), 23(3), 27(1), 29(1)(a) and 32(1)) protect eight specific domains of children's development (physical, mental, moral, social, cultural, spiritual, personality and talent). This broad protection for children's development is the ultimate expression of international children's rights law's aspirationto protect children's journey towards adulthood. Thisaspiration mirrors the prevailing sociologicalconception of childhood in the West, known as the 'human becomings' approach. According to this approach, children are generally perceived as weak, immature, and in need of protection in order to survive the process of transforming into adults. The emergence of a new conception of childhood, 'the human beings' approach, that conceives children as people in their own right and recognises their agency, did not influence the Convention's treatment of children's development. Although the Convention embraces, to different degrees, both conceptions of childhood, when it comes to the child's development it is entrenched with the image of childrenas adults in the making, and the sense that there is 'something very strange about thinking of children as bearers of rights' ${ }^{3}$ Other approaches toward childhood, children and the maturation process, such as those of Korczak or the child liberation movement, ${ }^{4}$ did not get much attention and have been either neglected or dismissed in the literature, in the few times they were mentioned; not least because these approaches challenge the tradition of perceiving children in psycho-social developmental terms.

The history of international children's rights law in general, and the drafting process of the Convention in particular, demonstrates that the comprehensive protection for children's development and the creation of children's unique right to development were intended to meet society's concern for children's future. The study of the Convention's travaux préparatoires has shown that while the term 'children's development' (and its

\footnotetext{
${ }^{3}$ Harry Brighouse, 'What Rights (If Any) Do Children Have?' in David Archard and Colin Macleod (eds), The Moral and Political Status of Children (Oxford University Press, Oxford 2002) 31-52, 31.

${ }^{4}$ See chapter one.
} 
subsequentterms such as 'moral development' or 'emotional development') was mentioned time and again during the drafting process, no discussions about its meanings took place. Based on the Convention's drafting history, I have suggested seeing Article 6 as a representation of a continuum, where the right to life is located at the negative end, and the right to development is located at the opposite, positive, end, with the right to survival located in between the two. As a positiveright, the child's right to development can be understood as a right that protects the child's needs required for a healthy process of growth. This interpretation suffers from some inherent limitations, including its sole care for the child's future and its lack in respect for children's agency. It also assumes knowledge about the meaning of 'healthy process of growth', and the components of this process. Another problem is its insufficient differentiation between the right to development as an independent right and the right to development as an umbrella right, which only summarises the other five Articles of the Convention that protect specific domains of children's development.

The UN Committee on the Rights of the Child's approach to the right to development is another link in the chain of theorising the child's right to development. As chapter three shows, the Committee understands the child's right to development as a means to an end - as a tool for facilitating the child's transformation into an adult. On the one hand, the Committee defined the right to development as one of the Convention's guiding principles. On the other hand, the Committee focuses on the care for children's development, ignoring the right to development. This dichotomy is further reflected in the Committee's jurisprudence, where it defined the connection between most of the Convention's rights to children's development in one of two ways: rights that are instrumental to the promotion of children's development,and rights that protect substantial elements of development. While the Committee did not say what children's development stands for, it implicitly employs mainstream developmental psychology when referring to this term, and kept silence about the meaning of the child's legal right to development. Thus, the Committee did notmeet its own interpretation guidelines, ${ }^{5}$ and so far has not provided a coherent, distinct and meaningful interpretation of the child's right to development.

I have suggested two explanations for this disappointing jurisprudence. First, when it comes to children's development, the Convention, and subsequently the Committee, are confined

\footnotetext{
${ }^{5}$ UNCRC 'General Comment 5 - General Measures of Implementations of the Convention on the Rights of the Child' (27 November 2003) UN Doc CRC/GC/5/2003.
} 
within the perception of children as 'human becomings'. This conception limits the scope of potential interpretations, does not aligned with core human rights principles and leads the Committee to subjugate most of the Convention's rights for the care of the child's future, overlooking children's personhood. Second, the Committee often interpreted the term 'children's development' in accordance with mainstream developmental psychology. Subjugating 'children's development' to this approach of psychology ignoresother psychological theories, as well as the biases of this particular body. Perhapseven more important is that this interpretation ignores the meaning of 'development' in other disciplines such as pedagogy, anthropology, economics and political science, and their potential contributions to the interpretation of the child's legal right to development. As some members of the Committee boldly admitted at the interviews I had with them, ${ }^{6}$ the lack of understanding of the term 'the right to development' leads the Committee to ignore the right to development, assuming that 'development' will happen on its own, as a result of protection of other rights.

Against this background, the next section suggests a framework for interpreting the child's right to development. This framework, I argue, can remedy these shortcomings and enables the articulation of 'children's development' in human rights terms.

\section{$\underline{\text { A Roadmap for Change }}$}

I propose to frame the analysis of the child's right to development according to the following two core elements: First, abandoning the usage of polarised conceptions of childhood in favour of a hybrid conception, where the child's present and future are recognised as equally important.Key components of the hybrid conception of childhood are the respect for children's agency and for children as social agents. Second, I suggest to reconceptualise the meaning of 'children's development' in a way that syntheses the Capability Approach's emancipatory idea of 'human development' with the Convention's conception of 'children's development'.

\footnotetext{
${ }^{6}$ See chapter four.
} 


\section{Adopting a Hybrid Conception of Childhood}

The two dominant conceptions of childhood - the 'human becomings' and the 'human beings' - limit, each in different ways, the scope of interpretation of the child's legal right to development. Both approaches confine 'the child' to one, homogenous and universal narrative of childhood: the child is either considered as a person in the making or as an agent in her own right.

Under the 'human becomings' idea, the child's right to development is interpreted as a means to an end: a right that aims to ensure that the child 'survive' the time of childhood and become an adult. In other words, the right to development is the right of the child to become an adult. ${ }^{7}$ The 'human beings' approach thus far has not informed the analysis of the child's right to development, despite the advantages of this approach. Using this approach in the analysis of the child's right to development can lead to respecting children as rights holders, to respecting children's views about their own development, and to recognising the importance of the process of maturation, rather than only its outcome. As such, it might be argued that using the 'human beings' approach instead of the 'human becomings' approach will remedy the limitations of the current interpretation of the child's right to development.

I see three problems withusingthe 'human beings' concept in this context. First, adopting the 'human beings' approach as the sole approach would inevitably lead to as polarized, and therefore distorted, interpretation of the child's right to development, as the usage of the 'human becomings' approach has led to. Neither of these two conceptions adequately comprehends the complexity of children's lives on their own. Second, the 'human beings' approach undermines the normative grounds of the construction of childhood in international children's rights law (and subsequently the grounds for the entire project of transforming children into adults). If we recognise the personhood of the child, the current intrinsic and instrumental meaning of the Convention's right to development will, to a large extent, loose their validity. Third, in light of the Vienna Convention on the Law of Treaties, the intentions of the Convention's drafters should not be easily dismissed. As chapter two has shown, the Convention's drafters followed the 'human becomings' concept of childhood in the Convention's drafting process.

When addressing the child's right to development, it should be realised that the present (beings) and the future (becomings) are intertwined in the child's life. Therefore, employing

\footnotetext{
${ }^{7}$ Compare with Michael Freeman, 'The Human Rights of Children’ (2010) 63 Current Legal Problems 1, 15.
} 
any polarized conception cannot result in any coherent, holistic, and contextualised interpretation of children's right to development. This argument does not dismiss the proposition that these two conceptions are not mutually exclusive, and that childhood could be conceptualised as both a time of being and a time of becoming. ${ }^{8}$ But accommodating these two concepts together 'simply accepts the child/adult dualism: the being child will become an adult'. ${ }^{9}$ It also reproduces the same binary images of childhood, which were created by adults in order to preserve their supremacy over children, to silence children's voices, and ignore their expectations from their own processes of maturation and development. ${ }^{10}$ Within the context of the child's right to development, this dualism will, at best, result in a fragmented interpretation that focuses on caring for the child's future, while only paying lip service to the child's life in the present.

I therefore suggest not conceiving childhood as a linear or binary experience. There is a need for a different concept, one that does not embrace only the extremes. ${ }^{11}$ The child should not be seen only as a 'human beings' or as a 'human becoming', but rather as a person that is engaged in a process of growth in her own right, anticipating changes in the future, including her or his life as an adult. The process of growing up is one important characteristic of childhood, but not the only one. This process should not be a reason for suppression, but rather a cause for empowerment. A hybrid conception of childhood is not a summary of the two conceptions of childhood, but a more complex idea. It is rooted in Korczak's writing:

'When I approach a child, I have two feelings: affection for what he is today and respect for what he can become...' 12

'Children are not the people of tomorrow, but people today. They are entitled to be taken seriously, they have a right to be treated by adults with tenderness and respect, as equal. They should be allowed to grow into whoever they were meant to be - the unknown person inside each of them in the hope for the future'. ${ }^{13}$

\footnotetext{
${ }^{8}$ Emma Uprichard, 'Children As 'Being and Becomings: Children, Childhood and Temporality' (2008) 22 Children \& Society 303.

${ }^{9}$ Freeman, supra n. 7, 15 .

10 According to James et al, the dichotomies between childhood and adulthood are: structure and agency, identity and difference, continuity and change, local and global. Allison James et al, Theorizing Childhood (Polity Press, London 1998) 199-218.

${ }^{11}$ Compare to Judith Butler, Gender Trouble (Routledge, New York 1999).

12 Janusz Korczak, Loving Every Child (Algonquin Books of Chapel Hill, North Carolina 2007) 17.

${ }^{13}$ Janusz Korczak, 'The Child's Right to Respect' in Janusz Korczak - The Child's Right to Respect: Lectures on Today's Challenges for Children (Council of Europe Publishing, Strasbourg 2009. Originally published in 1929) $23-43,36$.
} 
Korczak viewed children's lives as multi-dimensional, giving equal importance to the child's maturation process and to the child's future. According to this conception of childhood, the child's right to development can be understood as a right that respects the child for what she is now, for what she or he can be, and what she or he herself would like to be in the future.

The 'child's future'is a term that needs to be unpacked as well. The child's future should not only refer to the age of 18 and 'adulthood', as the Convention deems, ${ }^{14}$ but also for what a child sees as her own 'future'. For a child, the 'future' can also be the coming day or the coming month. There is a need to realise that time and temporality are dynamic and relational ideas. For a baby, for example, the concept 'future' does not only stand for being 'an adult', but it includes being a toddler, a pupil, an adolescent, and an adult.

Like the 'human becomings' and 'human being' conceptions, the hybrid conception of childhood carries ideological baggage as well. It is based on a moral claim towardschildren and human rights, and assumes universal acceptance to the ideas that children are human rights holders, and that the period of childhood is significant on its own. This conception adopts the culturally biased division of the human life span between adulthood and childhood, as well as the intra-division between different stages of childhood (infancy, adolescence etc). ${ }^{15}$ These biases should be taken into account when employing this conception and the suggested framework in different cultural contexts, but without compromising its core components. There should be no retreat from the idea that children are human rights holders.

\section{Upholding Children's Agency and Right to Participation}

The second principle I suggest adopting is inherent to the hybrid conception of childhood. This principle is respect for children's agency and children's right to participation as substantive and procedural elements of the right to development. The significance and implicationsof these two principles have been discussed in detail, primarily within the

\footnotetext{
${ }^{14}$ Article 1 . Childhood ends at the age of 18 , unless domestic law sets a younger age. The Convention does not mandate setting a later age. Childhood may very well not end at the age of 18. As a social concept, it can end before of after. As James Chisholm shows, the Native American Navajo's model of childhood, for example, includes eight stages of development that are not based on age but rather on social competence. Childhood therefore does not end at a specific age but rather after the person has progressed throughout the stages, which usually take until the age of thirty. James Chisholm, 'Learning "Respect for Everything": Navajo Image of Development' in Philip Hwang et al (eds) Images of Childhood (Lawrence Eribaum, New Jersey 1996) 167184.

${ }^{15}$ See Erica Burman, 'Local, Global or Globalized' (1996) 3 Childhood 46.
} 
contexts of the 'human beings' approach to childhood, ${ }^{16}$ the 'general' right to development, the Capability Approach and the child indicators movements. ${ }^{17}$ All of these examples demonstratenot only the theoretical significance of respecting children's agency and their right to participation, but also their practical implications. Here, I would like to expand further on the importance in the context of the right to development.

Recognising children's agency will inevitably change the discussion about 'children's development' and shift the attention from questions of competence and welfare to the question of human rights. Respecting children as human rights holders will enableto articulate the child's right to development as a distinct and concrete human right. In other words, Durkheim's 'law of growth' ${ }^{18}$ will become an issue of human rights law. The child will be seen as entitled to grow, and not only as in need of growing. Finally, recognising children's agency will also enable to broaden the meaning of the term 'development' in the 'right to development' beyond its current psycho-social developmental conception.

Another implication of respecting children's agency will be the respect for children's right to participation, which is probably the most profound right that symbolises the recognition of children's abilities - and right - to make sense of the world around them. ${ }^{19}$ Thus far, and despite the Convention'srecognition of the child's right to participation (Article 12), and the rights' definition as one of the Convention's four guiding principles, ${ }^{20}$ no meaningful connection has been made between thesetwo rights. Ignoring children's views in the context of their development perpetuates the image of children as passive subjects, whose sole purpose in life isto sit still and grow up.

The conceptual linkage between the right to development and the right to participation should not only be part of the implementation of the right to development, but should also be applied as part of the process of developing its meaning. Children should participate in the creation of a new interpretation of the right to development, and to contribute their own opinion on the subject. Children should also be part of the process of realising the right to development in practice, including in the process of developing implementation tools and practices (for example, developmental policies and programmes, and drafting new legislation on the subject).

\footnotetext{
${ }^{16}$ See the Introduction to this thesis.

${ }^{17}$ See chapter five.

${ }^{18}$ See the Introduction to this thesis.

${ }^{19}$ Gerison Lansdown, 'International Developments in Children's Participation: Lessons and Challenges' in Kay Tisdall et al (eds) Children, Young People and Social Inclusion (The Policy Press, Bristol 2006) 139-155.

${ }^{20}$ UNCRC 'General Comment 5', supra n. 5.
} 
Respecting children's agency and their right to participation does not meanthat children will dictate the course of their childhood and future adulthood. This proposal does not mandate 'full liberation', or 'abandoning' children to their rights. ${ }^{21}$ Not least because no one, children and adults alike, has a free standing in society. Children's participation does not mandate, whether we like it or not, children being the only decision makers. Nonetheless, the respect for children's agency means that the child will be considered as an active agent in her own life and as someone that can, and should, participate in her own development.

Children's participation also reflects, and promotes, the understanding of 'development' as an emancipatory process, which is the contribution of the Capability Approach (and to some extent, the 'general' right to development) to our analysis. The usage of the Capability Approach in the context of the child's right to development will be further discussed in the next section, but at this point I argue that manifestation of the right to development as an emancipatory right and giving children a voice in this process requires a social and cultural transformation. ${ }^{22}$ Such a change includes the creation of a "political space in which children are empowered to express their own distinctive and submerged point of view'. ${ }^{23}$ It will enable children, as a marginalised group, to express their own perspective ${ }^{24}$ about their own development.

\section{$\underline{\text { Re-Conceptualising 'Children's Development' }}$}

The last element I suggest adopting relates to the meaning of 'children's development' in the context of the child's right to development. First, the meaning of 'children's development' should be re-conceptualised, so it will not be interpreted only from a developmental psychology perspective. Re-conceptualising 'children's development' should be done by bringing together a range of disciplines that employ this term. For example, education, sociology, psychiatry, anthropology, medicine and political science. This process will expand the meaning of the term 'children's development', and will set the grounds for a crossdisciplinary understanding of it.

\footnotetext{
${ }^{21}$ Bruce C. Hafen and Jonathan O. Hafen, 'Abandoning Children to their Autonomy: The United Nations Convention on the Rights o the Child' (1996) 37 Harvard International Law Journal 449.

${ }_{22}$ Ragnhild Lund, 'At The Interface of Development Studies and Child Research: Rethinking Participating Child' (2007) 5 Children's Geographies 131.

${ }^{23}$ John Wall, 'Can Democracy Represent Children? Towards a Politics of Difference' (2012) 19 Childhood 86, 92.

${ }^{24}$ Nigel Thomas, 'Towards A Theory Of Children's Participation' (2007) 15 International Journal of Children's Rights 199, 210.
} 
As we saw earlier, there are two reasons for the ambiguity of the current interpretation of the child's right to development are: the fuzziness of the term 'children's development' for lawyers; and the miscommunication between professions that employ this term and lawyers. While in psychology, for example, 'children's development' has one meaning, in paediatrics this term has other meanings. A psychologist may have in mind the theories of Piaget or Freud, while for the paediatrician, the term 'stages of development' is probably linked to matrix of age, weight and height. Thus, the psychologists and the medical doctor may use the same words, but their content varies according to one's professional discipline. The common lawyer probably will not be able to contribute much to this conversation, mainly because the term 'children's development' is not part of legal vocabulary. The suggested reconceptualisation process can narrow down this disciplinary gap, and enable to interpret the child's right to development in a more coherent manner.

The unfamiliarity of legal scholars with the term 'children's development' can be explained by comparing this right to the right of freedom of speech. When a lawyer interprets the right to freedom of speech, the meaning of 'speech' is clear to him or her. 'Speech' and 'freedom of speech' were, and still are, the subjectsof extensive academic writing and have been adjudicated for many years in domestic, regional and international fora. The meaning of 'speech' in the context of the right to freedom of speech has changed over the years, ranging from protecting a person that stands on Speakers Corner in Hyde Park to protests against the government, to include commercial advertising, and tweeting. Lawyers were able to realise that these changes in the forms, fora and content of 'speech' have happened, and were able to reinterpret the right to freedom of speech accordingly.

Legal scholars therefore need to consult with professionals from other fields in order to be able to comprehend the term 'children's development'. Educators, psychologists, social workers, sociologists, paediatricians, political scientists and children (from a range of personal and professional backgrounds, professional streams and geographical locations)should contribute to the discussion. ${ }^{25}$ Such a consultation will not result in creating a unified understanding of the term 'children's development', nor should it. 'Children's development' is a normative idea, not a neutral one.

\footnotetext{
${ }^{25}$ Claire Cassidy advocates for creating a dialogue between children and adults as part of realizing children's right to participation and empowering children. Claire Cassidy, Thinking Children (Continuum International, London 2009) 173-176.
} 
This consultation does not, and will not, make lawyers expert in any other discipline. Nor should they. But they should be able to understand what 'children's development' stands for in different disciplines, in order to overcome their inherent professional limitations and be able to articulate this concept in human rights terms. Without having a clearer idea of what 'children's development' means, any attempt to interpret the legal right to development is destined to fail.

A cross-disciplinary consultation will enable the interpreters of the right to articulate what 'development' in the right to development stands for. For example, what is the meaning of the eight developmental domains that the Convention mentions? Are there additional aspects that should be included? How should 'physical' development or 'moral' development, to name just two of the eight, be defined and according to which discipline? Only then, after the normative grounds are set, will it be possible to articulate children's development in human rights terms, and to ask what sorts of entitlements this right creates, and what kinds of duties it imposes on different duty bearers. Subsequently, it will be possible to concretise its components and meaning and develop empirical indicators to measure its implementation.

Second, as part of the re-conceptualisation process, I suggest integrating the Capability Approach's conception of human development into the interpretation of the 'child's right to development'. Synthesising the Capability Approach's idea of emancipation, alongside the insights of psychology, pedagogy etc, will enable to broaden the meaning of this right, and to add a new moral dimension to it. While medicine or education can tell us what qualifies as a 'good' or 'normal' development, and how these ideas are best served, using the Capability Approach will enable to re-define the aim of the right, so it will mean more than just a right to grow up.

Adaptation the term 'children's development' into legal norms should be done cautiously. ${ }^{26}$ Emily Buss has recently discussed the connection between law and the science with respect to child's development (in the context of USA children's constitutional rights case law). ${ }^{27}$ Buss claimed that the discussions about children's rights usually focus on children's capacities in order to determine their guilt, sentencing and the interpretation of their constitutional rights. She identified four limitations of this approach: law cannot

\footnotetext{
${ }^{26}$ For a general overview of the relationship between law and science see Helen Reece (ed), Law and Science (Oxford University Press, Oxford 1998). See also Barbara Beatty et al (eds), When Science Encounters the Child - Education, Parenting and Child Welfare in $20^{\text {th }}$ Century America (Teachers College Press, New York 2006).

${ }^{27}$ Emily Buss, 'What the Law Should (and Should Not) Learn From Child Development Research' (2009-2010) 38 Hofstra Law Review 13.
} 
accommodate the complexity of social science; this approach perpetuates the supremacy of the 'competent adult' image and dictates assessing children accordingly; it prevents from achieving coherence in children's constitutional rights law; if focuses on children's current capacities in order to determine their legal competence distracts attention from the child's future. ${ }^{28}$ Buss therefore suggests changing the way that law treats child's development. She suggests that it is the role of lawyers to interpret the law while considering what science has to say.

Children's rights analysis should be informed by child's development studies, and law, as Buss adequately put it, should be put back in the driver's seat. ${ }^{29}$ In our context, it is the role of legal scholars to interpret the legal entitlement of children to develop. But Buss's articulation of children's development and the question of capacities are too narrow and confine children's agency to the question of competence. Children's legal right to development should have a broader and more complex meaning than what Buss suggests.

The hybrid conception of childhood can help to achieve this goal, since it changes the way the discussion is framed. If we look at these issues as representations of different perspectives on the relationship between children and human rights, then the child's current capacities should not be a reason for denying children their right to development, while at the same time the care for the child's future should not be so easily dismissed. These two dimensions - the current and anticipated capacities - and the care for both are not mutually exclusive, but rather, they merge in a harmonious way in children's legal right to development. At this point the contribution of synthesising the Capability Approaches' conception of human development into the interpretation of the child's right to development becomes even clearer. As a human right, the right to development should provide the child the entitlement to be an active agent in her own development.The right to development will not only mean the right to become an adult, but rather it can mean the right to be a free child, while becoming a free adult.

How the process of 'development' should result is a question rarely discussed. When it is addressed, the vague answer usually given, also by the UN Committee on the Rights of the Child, is that the child should become an adult. Most of the discussion tends to focus on the process of development, expressing wishes that the child will develop 'normally', or in a 'healthy' manner. A unique perspective about the result of the maturation process can be

\footnotetext{
${ }^{28} \mathrm{Ibid}, 20-34$

${ }^{29}$ Ibid, 15.
} 
found in the drafting process of the Convention, ${ }^{30}$ and in the Convention's definition of the aims of education. There, the Convention asks to see the child fulfil her or his human potential as the result of development. The Committee has embraced this perspective on children's development on a small number of occasions, mostly with respect to education. ${ }^{31} \mathrm{I}$ suggest moving this perception to the centre of the discussion, and to interpret the child's right to development as a right that aims to protect and promote the fulfilment of the child's human potential to the maximum. This approach focuses on every child as an individual and is tuned to the inner capacities of each child.

Defining the aims of the developmental in such a manner does not ignore the process of development or its significance. On the contrary; this aim, in the context of the suggested hybrid conception of childhood, requires that the process of development will not hinder the potential of the child. The process of maturation and the experiences of children throughout it, are inherently important to the child's ability to fulfil her or his potential in every step of the way. Moreover, the care for the child's potential is shared by many cultures, and not only by Western cultures, and thus caries less cultural bias and ideological bags than the dismissal of the child's agency. Therefore, this concept can be more easily accepted in different contexts, and more easily implemented (or enforced, if needed).

Since there is no paradigmatic child, and there is no one singular and universal childhood, ${ }^{32}$ there is also no one right way to develop. Different childrenexperience different childhoods, and different processes of development. Therefore, there is a place to argue that there should be no one, universal and contextless meaning for the term 'children's development' and the right to development.Furthermore, as an emancipatory right, the right to development will acknowledge the child's right to develop in different ways, as long as it enables the child to fulfil her potential. The interpretation of the right to development should leave a space to accommodate such a variety of life experiences of children.

\footnotetext{
${ }^{30}$ UNHCR, 'Report of the Working Group on a Draft Convention on the Rights of the Child' (25 March 1983) UN Doc E/CN.4/1983/62.

31 See, for example, UNCRC 'Concluding Observations: New Zealand' (24 January 1997) UN Doc CRC/C/15/Add. 71, paragraph 5; UNCRC 'General Comment 1 - Article 29(1): The Aims of Education' (17 April 2001) UN Doc CRC/GC/1/2001; UNCRC 'Concluding Observations: Slovakia' (23 October 2000) UN Doc CRC/C/15/Add. 140, paragraph 46; UNCRC 'Concluding Observations: Thailand' (17 March 2006) UN Doc CRC/C/THA/CO/2, paragraph 64 .

${ }^{32}$ Freeman, 'Towards a Sociology of Children's Rights', supra n. 2, 33.
} 


\section{A New Framework for Analysing the Child's Right to Development}

This section presents a new framework for the analysis of the child's right to development. This framework aims to enable to create a coherent interpretation of the right, distinguishing it from other rights of the child and differentiating between its meanings as a human right and as a guiding principle of the Convention. This approach applies the hybrid conception of childhood, comprehends broad and complex meanings of 'development', and distinguishes between substantial and procedural elements of the right. Thissuggested framework, however,does not provide a conclusive definitionfor the child's right to development. Such a definition should be the result of applying this framework with a specific understanding of 'children's development'.

Children's development should be perceived as a human right of all children. ${ }^{33}$ The right to development should be realised in accordance with its dual roles:an independent right of children, and a guiding principle of the Convention. ${ }^{34}$ As a separate human right, the child's right to development should be seen as a composite right that respects, protects and promotes the child's process of development, as well as its outcome, with the aim to enable the child to fulfil her human potential to the maximum. As a guiding principle, the right should be seen as a litmus test for scrutinising actions that impact children's lives and development.

The right should not be seen only as a summary of other human rights that support children's development.This interpretation is different from current views that see the promotion of children's development as a by-product of the realisation of other human rights of the child, such as the right to education or health (as, for example, the UN Committee on the Rights of the Child suggests). At this point it is worth reminding Sengupta's explanation about the realisation of the 'general' right to development as a composite right, which means that 'the whole is greater than the sum of the parts....the composite rights are related in a non-linear way with positive feedback... ${ }^{35}$ Understanding the child's right to development as a composite right means that it will comprehend all eight development domains protected by the Convention, as well as the child's rights to participation and non-discrimination, ${ }^{36}$ with the aim of enablingthe child to be free to fulfil her or his human potential.

\footnotetext{
33 And not only of small children as Woodhead has suggested. Martin Woodhead, 'Early Childhood Development: A Question of Rights' (2005) 37 International Journal of Early Childhood 80.

${ }^{34}$ UNCRC, 'General Comment Number 5', supra n.20.

${ }^{35}$ Arjun Sengupta, 'The Human Right to Development' (2004) 32 Oxford Development Studies 179, 183.

${ }^{36}$ Compare to UNCRC, 'General Comment number 5', supra n. 20.
} 
The right to development has a holistic objective that elevates the realisation of other rights to a different dimension. This perception will enable to define the aims of the right also as the right that enables the child to have as many options as possible to live her life. The right should enable the child to be aware of the range of available options and to increase choices and freedoms,entitle the child to have the necessary capabilities to choose, the voice to articulate her preferences, and ensure that these preferences are taken into account in a nondiscriminatory way. The child's right to education serves other ends than those served by the right to development. The right to education also reflects different, but partially overlapping, justifications, including, but not limited to, the support for the child's development. Teaching the child how to read and write has its own values and reasons. It allows the child to acquire new skills and knowledge, and as such, promotes the child's intellectual development. It also contributes to the child's emancipation by creating future opportunities and in doing so promotes the fulfilment of the child's potential. But realising the child's right to education does not satisfy all the child's developmental needs, nor is it equal to realising the child's fullest potential. The child has more developmental needs, and realising her or his fullest potential require more than the capability to read and write. Therefore, while education is a necessary component of realising the right to development, the right to development is more comprehensive.

What is required as 'support' for child's development depends on how we define this term. A potential source for articulating the components of development is the Convention and the eight developmental domains it mentions. Another source is the list of capabilities necessary for 'development', which were described in chapter five. While Nussbaum's list of ten capabilities was not tailored for children, Biggeri and Mehrotra's list of fourteen capabilities seems more adequate. ${ }^{37}$ The various indices that the child indicator movement has created are another potential sources. All of these examples demonstrate the feasibility of articulating children's development in concrete terms, identifying its components and then adapting these components to human rights terms. Further articulation of a child-specific list of capabilities is needed. Such a list should be based on a different conception of 'child's development' than those currently available.

As a guiding principle of the Convention, the right to development should be used as a benchmark for scrutinising decisions that affect children as a collective and as individuals. It means that when a duty bearer takes an action, not only the right to non-discrimination, the

\footnotetext{
${ }^{37}$ See chapter five.
} 
right to participation and the best interests of the child that should be respected, but also the right to development. Every decision, policy and piece of legislation should be measured against its impact on the right to development. ${ }^{38}$

Substantiating the right to development as a guiding principle of the Convention should be done in accordance with three factors: the understanding of the right to development as an independent right; and the 'maximum available resources' test set by Article 6 of the Convention; ${ }^{39}$ and the division of responsibilities between different actors according to Articles 4, 5 and 18 of the Convention. To some extent, the UN Committee on the Rights of the Child already employs this perspective. Although the Committee ignores the right to development as an independent right, it nevertheless examines legislation and policies with respect to their potential or actual impact on children's development (and not on the right to development). Using the example of education one more time, understanding the right to development as a guiding principle means that every decision that affects children, for example the budget of the ministry of education, schools' enrolment policies, curricula and schools' disciplines, should be measured against its impact on the child's right to development (and not only children's development). Articulating the role of the right to development as a guiding principle in this way might resemble or overlap with the role that the principle of the best interests of the child has, as a primary consideration (Article 3 ). In the future, there is a need to address the relationship, and potential overlaps, between these two guiding principles.

\footnotetext{
${ }^{38}$ Compare with Marta Maurás' suggestion on the relationship between public policies and the implementation of the Convention. Marta Maurás, 'Public Policies and Child Rights: Entering the Third Decade of the Convention on the Rights of the Child' (2011) 633 ANNALS 52, 56.

${ }^{39}$ The meaning of the term 'maximum available resources' is beyond the scope of this research.
} 


\section{Conclusion}

International children's rights law in general, and the Convention on the Rights of the Child in particular, tells us a convincing story about children and children's development. The child is a person in making that should enjoy the maximum available resources in order to develop and become an adult. More specifically, the Convention tells us that the child has a right to develop.

The child, the Convention's preamble asserts, should 'grow up in a family environment, in an atmosphere of happiness, love and understanding.' Accordingly, parents not only need to love and understand their child, but also bear the responsibility for 'the upbringing and development of the child' (Article 18). The child's material standard of living should be adequate for 'the child's physical, mental, spiritual, moral and social development' (Article 27). Education is expected to develop 'the child's personality, talents and mental and physical abilities' (Article 29).

The Convention therefore tells us how 'development' should be supported and what the potential factors that put its implementation at risk are. Littleis said about how 'development' should end. With the exception of Article 29, the Convention is silent about the person that the child should turn into upon becoming an adult.

Although the protection for children's development is embedded in the Convention, and although the Convention is the only binding treaty that protects the right to development, only a handful of studies have asked what 'children's development' means once articulated as a human right. This thesis fills this gap, and suggests a framework for understanding the child's legal right to development, with the hope that a lively debate will follow this suggestion.

In chapters one and two I described the background for creating children's unique right to development. I argued that in order to understand the child's right to development, there is a need to realise the social conceptions that led to its creation. Chapter one reviewed the development of children's rights law and theory, highlighting the importance given to the protection of children's development, and the ways in which this term was understood. Chapter two systematically analysed the drafting process of the Convention on the Rights on the Child, aiming to understand the motivations for including a broad protection for children's development in this pioneering treaty. The chapter shows that while the care for children's development was always an issue for the Convention's drafters, no significant 
attention was given to the meaning of the legal right to development. Chapter three analysed how the UN Committee on the Rights of the Child has interpreted this right. The findings of this analysis reaffirm the hypothesis about the dominance that the 'human becomings' conception of childhood has in the interpretation of the Convention's protection for children's development. While the Committee ascribes a broad protection for an undefined concept of 'children's development,' it ignores, almost entirely, children's legal right to development. Chapter four followed up on this point in a series of interviews with members of the UN Committee on the Rights of the Child. The Committee members gave several reasons for the Committee's insufficient jurisprudence on the right to development, ranging from blaming States Parties for ignoring the right, to admitting that the Committee simply does not know how to address this right. An analysis of the Committee's 'chain of monitoring' shows that it does not matter what States Parties write in their implementation reports, the Committee is likely to ignore the right to development. Chapter five addressed two of the main obstacles that preclude adequate interpretation of the right to development: the diverse meaning of 'development' and the difficulty of concretising this term. The chapter suggested comparing the child's right to development with some elements of the 'general' right to development and with the Capability Approach. Primarily, the chapter demonstrated the importance of recognising the agency of the right holder, the differentiation between the process of development and its outcome and the articulation of development as an emancipatory idea. The chapter further analysed a number of indices that take specific conceptions of development and delineated their measurable components.

Following this trajectory, chapter six offers a new framework for the analysis of the child's right to development. The suggested framework is broad and comprehensive. It holds great promise for children. It can lead to the creation of a concrete interpretation of the child's right to development. It accommodates a hybrid conception of childhood that respects children's agencyand comprehends wide-ranging perspectives of 'children's development'. These include, but are not limited to, the Convention's eight developmental domains and the Capability Approach's idea of development as freedom. These conceptions of development are a good starting point to conduct a cross-disciplinary consultation about the meaning of 'children's development'. The suggested framework takes substantive and procedural rights together, in order to create a right that is greater than the summery of its parts. The aim of this right is to enable the child to fulfil her potential to the maximum.

To paraphrase Korczak one last time, the right to development should be understood as a 
right to ensure the 'optimal conditions to grow and develop', as well as the right to 'live in the present'. ${ }^{1}$ These aims are not mutually exclusive, but rather, complement each other. They represent a concept that acknowledges the right to development of children whilst defining the idea of 'development' in complex terms.

The framework I suggest is articulated in relatively general terms so that it can meet the 'challenge', as Smart, Neale and Wade put it, ${ }^{2}$ of exploring the plurality of childhood and of children's development. The suggested framework should be employed in a context-sensitive manner, with the realisation that children are not a homogenous group. Since there is no paradigmatic 'child', there is no paradigmatic 'development'. Children vary in their experiencesof their childhood, as it is shaped by their identities and the ways they intersect. Children can develop in different ways, experience their childhoods differently and grow up to become different people. The meaning of 'normal' development therefore varies in different contexts and cultures.

There is a need to be aware of the differences between children with respect to gender, sexual orientation, class, ethnicity, disability, religion, culture and age. These characteristics should first apply to children themselves, and not to adults. Respecting children's agency means that we should not measure or compare children to adults. All of these factors can influence children's perceptions about their life, shape the opportunities that they can generate for themselves, and the opportunities that society offers them. The interpretation of the legal right to development should reflect this understanding.

\footnotetext{
1 Janusz Korczak, Loving Every Child (Algonquin Books, Chapel Hill, North Carolina 2007. Originally published in 1919) 355.

${ }^{2}$ Carol Smart et al, The Changing Experience of Childhood (Polity Press, Cambridge 2001) 12.
} 


\section{$\underline{\text { References }}$}

\section{$\underline{\text { Books }}$}

Anderson Moore K. and Lippman L. H., What Do Children Need to Flourish? (Springer, New York 2005).

Archard D., Children: Rights and Childhood (2 ${ }^{\text {nd }}$ edition Routledge, London 2004).

Ariès P., Centuries of Childhood - A Social History of Family Life (Translated by Robert Baldick, Jonathan Cape, London 1962).

Bayefsky A. F., The UN Human Rights Treaty System - Universality at the Crossroads(Kluwer Law International, The Hague 2001).

Beiter K. D., The Protection of the Right to Education by International Law (Martinus Nijhoff Publishes, Leiden 2006).

Berger K. S., The Developing Person (7 $7^{\text {th }}$ edition, Worth Publishers, New York 2006).

Bluebond-Langer M., The Private Worlds of Dying Children (Princeton University Press, Princeton 1978).

Boserup E., Women's Role in Economic Development (Earthscan, Revised Edition 2007. Originally published in 1970).

Bowlby J., A Secure Base: Clinical Applications of Attachment Theory (Routledge, London 1988).

Boyden J. and Bourdillon M. (eds) Childhood Poverty - Multidisciplinary Approach (Palgrave Macmillan, Basingstoke 2012).

Bridges K. M. B., The Social and Emotional Development of the Pre-School Child (Kegan Paul, Trench, Trubner\&Co, London 1931).

Bryman A., Social Research Methods ( $3^{\text {rd }}$ edition, Oxford University Press, Oxford 2008).

Butler J., Gender Trouble (Routledge, New York and London 1999).

Burman E., Deconstructing Development Psychology (2 ${ }^{\text {nd }}$ edition, Palgrave, London 2008).

Burman E., Development - Child, Image, Nation (Routledge, London 2008).

Cassidy C., Thinking Children (Continuum International, London 2009).

Cohen C. P., Jurisprudence on the Rights of the Child, Volumes 1-4 (Transnational Publishers, New York 2005).

Diduck A., Law's Families (LexisNexis, London 2003).

Drèze J. and Sen A., India: Economic Development and Social Opportunity (Oxford University Press, Oxford 1995). 
Easterly W., The White Man's Burden (Oxford University Press, Oxford 2006).

Escobar A., Encountering Development: The Making and Unmaking of the Third World (Princeton University Press, Princeton 1995).

Fass P. S., The Damned and the Beuatiful - American Youth in the 1920's (Oxford University Press, Oxford 1977).

Eppler K. S., Dependent States: The Child's Part in Nineteenth-Century American Culture (University of Chicago Press, Chicago 2005).

Farson R. E., Birthrights (Macmillan, University of Michigan Press, Michigan 1974).

Freeman D., Margaret Mean and Samoa: The Making and Unmaking of an Anthropological Myth (Harvard University Press, Cambridge and London 1983).

Freeman M., The Rights and Wrongs of Children (Frances Pinter, London 1983).

Freeman M., The Moral Status of Children (Martinus Nijhoff Publishers, The Hague 1997).

Freeman M., Article 3 - The Best Interests of the Child (Martinus Nijhoff Publishers, Leiden 2007).

Gilligan C., In a Different Voice (Harvard University Press, Cambridge, Massachusetts 1982).

Goldstein J. et al, The Best Interests of the Child: The Least Detrimental Alternative (Simon\&Schuster, New York 1996).

Griffin J., Well-Being (Clarendon Press, Oxford 1986).

Heywood C., History of Childhood (Polity Press, London 2001).

Holt J., Escape From Childhood (Penguin Books, Middlesex 1974).

Hopkins B. (ed), The Cambridge Encyclopedia of Child Development (Cambridge University Press, Cambridge 2005).

Hulme D. and Turner M., Sociology and Development (Harvester Wheatsheaf, New York 1990).

Illich I. D, Celebration of Awareness (Calder\&Boyars, London 1969).

Ishay M. R., The History of Human Rights (University of California Press, Berkeley 2008).

James A. et al, Theorizing Childhood (Polity, Cambridge 1998).

James A. and James A., Constructing Childhood (Palgrave Macmillan, Basingstoke 2004).

Kabber N., Reserved Realities - Gender Hierarchies in Development Thought (Verso, London 1994).

Key E., The Century of the Child (G.P. Putnam's Sons, New York and London 1909). 
King M. and Piper C., How the Law Thinks About Children (Gower, Vermont 1990).

Korczak J., Loving Every Child(Algonquin Books of Chapel Hill, North Carolina 2007).

Korczak J., The Child's Right to Respect (Council of Europe, Brussels 2009. Originally published in 1927).

Lansdown G., The Evolving Capacities of the Child (Save the Children and UNICEF, Florence 2005).

Lewis W. A., The Theory of Economic Growth (Routledge, London 2007. Original published in 1950).

Lee N., Childhood and Society (Open University Press, Gosport 2001).

LeVine R. A. and New R. S., Anthropology and Child Development (Blackwell Publishing, Malden, Massacusets and Oxford, England 2008).

Lifton B. J., The King of Children-A Biography of Janusz Korczak (Chatto \& Windus, London 1988).

Mason J., Gender and Development ( $2^{\text {nd }}$ edition, Routledge, London 2011).

Mason M. A., From Father's Property to Children's Rights - The History of Child Custody in the United States (Columbia University Press, New York 1994).

Mayall B., Towards a Sociology of Childhood: Thinking From Children's Lives (Open University Press, Gosport 2002).

Maynes, M. J., Schooling in Western Europe (State University of New York Press, Albany 1985).

McEwan C., Postcolonialism and Development (Routledge, New York 2009).

McNairm L., The Law of Treaties (Oxford University Press, Oxford 1961).

Mead M., Coming of Age in Samoa: A Psychological Study of Primitive Youth for Western Civilisation (Harmondsworth, Penguin Books 1943. First published in 1928).

Mintz S., Huck's Raft - A History of American Childhood (Harvard University Press, Cambridge 2004).

Montgomery H., An Introduction to Childhood (Wiley Blackwell, Chichester 2009).

Morsink J., The Universal Declaration on Human Rights - Origins, Drafting and Intent (University of Pennsylvania Press, Philadelphia 1999).

Mulley C., The Women who Saved the Children (Oneworld, Oxford 2009).

Nolan A., Children's Socio-Economic Rights, Democracy and the Courts (Hart, Oxford 2011).

Nowak M., Article 6: The Right to Life, Survival and Development (Martinus Nijhoff 
Publishers, Leiden 2005).

Nowak M., U.N. Covenant on Civil and Political Rights - CCPR Commentary(N.P. Engel, Kehl 1993).

Nussbaum M., Creating Capabilities - The Human Development Approach (Harvard University Press, Cambridge 2011).

Patterson D., Law and Truth (Oxford University Press, Oxford 1996).

Platt A. M., The Child Savers - The Innovation of Delinquency $\left(2^{\text {nd }}\right.$ edition, The University of Chicago Press, Chicago 1977).

Postman N., The Disappearance of Childhood (Vintage Books, New York 1984).

Prout A., The Future Of Childhood (Routledge, London 2005).

Reece H. (ed), Law and Science (Oxford University Press, Oxford 1998).

Salomon M., Global Responsibility for Human Rights (Oxford University Press, Oxford 2007).

Sen A., Development as Freedom (Oxford University Press, Oxford 1999).

Sen A., Inequality Re-examined (Harvard University Press, Cambridge, Massachusetts 1992).

Smart C. et al, The Changing Experience of Childhood (Polity, Cambridge 2001).

Smith R., A Universal Child? (Palgrave Macmillan, London 2009).

Stafford C., The Roads of Chinese Childhood (Cambridge University Press, Cambridge1995).

Stainton Rogers R. and Stainton Rogers W., Stories of Childhood (University of Toronto Press, Toronto 1992).

Steiner H. et al, International Human Rights Law in Context $\left(3^{\text {rd }}\right.$ edition, Oxford University Press, Oxford 2007).

Tomuschat C., Human Rights - Between Idealism and Realism (2 ${ }^{\text {nd }}$ edition, Oxford University Press, Oxford 2008).

Turmel A., A Historical Sociology of Childhood: Developmental Thinking, Categorization and Graphic Visualisation (Cambridge University Press, Cambridge 2008).

ul Haq M., Reflections on Human Development (Oxford University Press, Oxford 1995).

UNHCHR, Legislative History of the Convention on the Rights of the Child, Volumes I-II (New York and Geneva 2007).

Uvin P., Human Rights and Development (Kumarian Press, Sterling Virginia 2004).

Van Bueren G., The International Law on the Rights of the Child (Martinus Nijhoff Publishers, The Hague 1998). 
Veerman P., The Rights of the Child and the Changing Image of Childhood (Martinus Nijhoff

Publishers, Leiden 1992).

Wall J., Ethics in Light of Childhood (Georgetown University Press, Washington DC 2010).

Wells K., Childhood in a Global Perspective (Polity Press, Cambridge 2009).

Wolff J. and De-Shalit A., Disadvantage (Oxford University Press, Oxford 2007).

Wyness M., Childhood and Society (Palgrave, Basingstoke 2006).

\section{Chapters in Books}

Adams P., 'The Infant, the Family and Society' in Adams P. et al (eds) Children's Rights (Elek Books, London 1971) 51-90.

Aldgate J. 'Child Well-Being, Child Development and Family Life' in McAuley C. and Rose W. (eds) Child Well-Being (Jessica Kingsley Publishers, London 2010) 21-38.

Alkire S., 'Using The Capability Approach: Prospective and Evaluative Analyses' in Comin F. et al (eds) The Capability Approach (Cambridge University Press, Cambridge 2008) 2650 .

Arajärvi P., 'Article 26' in Alfredsson G. and Eide A. (eds) The Universal Declaration on Human Rights (Martinus Nijhoff, The Hague 1999) 551-574.

Archard D., 'John Locke's Children' in Turner S. T. and Matthew G. B. (eds) The Philosopher's Child (University of Rochester Press, Rochester 1998) 85-104.

Archard D., 'Philosophical Perspectives on Childhood' in Fionda J. (ed) Legal Concepts of Childhood (Hart, Oxford 2001) 43-56.

Ballet J. et al, 'Children Agency and the Capability Approach - A Conceptual Framework' in Biggeri M. et al (eds) Children and the Capability Approach (Palgrave Macmillan, Basingstoke 2011) 22-46.

Barnes A., 'CRC's Performance of the Child as Developing' in Freeman M. (ed) Law and Childhood Studies (Oxford University Press, Oxford 2012) 392-418.

Basu K., 'Prologue' in Biggeri M. et al (eds) Children and the Capability Approach (Palgrave Macmillan, Basingstoke 2011) XI.

Barbara B.et al (eds), When Science Encounters the Child - Education, Parenting and Child Welfare in 20th Century America (Teachers College Press, New York 2006).

Berger N., 'The Child, the Law and the State' in Adams P. et al (eds) Children's Rights (Elek Books, London 1971) 153-179.

Biggeri M. et al, 'Children's Agency and the Capability Approach: A Conceptual Framework', In Biggeri M. et al (eds) Children and the Capability Approach (Palgrave, Basingstoke 2011) 22-45. 
Biggeri M. and Mehrotra S., 'Child Poverty as Capability Deprivation: How to Choose Domains of Child Well-being and Poverty', In Mario Biggeri et al (eds) Children and the Capability Approach (Palgrave, Basingstoke 2011) 46-75.

Bishop S., 'Children, Autonomy, and the Right to Self-determination' in Aiken W. and LaFollette H. (eds) Whose Child? (Rowman and Littlefield, Totowa, New Jersey 1980) 154177.

Bourdillon M., 'Introduction' in Boyden J. and Bourdillon M. (eds) Childhood Poverty Multidisciplinary Approach (Palgrave Macmillan, Basingstoke 2012) 1-12.

Brighouse H., 'What Rights (If Any) Do Children Have?' in Archard D. and Macleod C. (eds), The Moral and Political Status of Children (Oxford University Press, Oxford 2002) 3152.

Chisholm J., 'Learning “Respect for Everything": Navajo Image of Development' in Hwang P. et al (eds) Images of Childhood (Lawrence Eribaum, New Jersey 1996) 167-184.

Comim F. et al, 'Introduction - Theoretical Foundations and the Book's Roadmap' in Biggeri M. et al (eds) Children and the Capability Approach (Palgrave, Hampshire 2011) 3-21.

deMause L., 'The Evolution of Childhood', in deMause L. (ed) The History of Childhood (Souvenir Press, London 1976) 1-74.

Deneulim S., 'Ideas Related to Human Development' in Deneulim S. and Shahani L. (eds) An Introduction to the Human Development and Capabilities Approach (Earthscan, London 2009) 49-70.

Doek J. E., 'The CRC: Dynamics and Directions of Monitoring Its implementation' in Invernizzi A. and Williams J. (eds) The Human Rights of Children (Ashgate Falmer, Farnham 2011) 99-116.

Durkheim E., 'Characteristics of childhood', in Pickering W.S.F. (ed) Essays on Morals and Education (translated into English by H.L. Sutchliffe, Routledge, London 1979. First published in 1991) 150.

Eide A. and Eide W. B., 'Article 25' in Alfredsson G. and Eide A. (eds) The Universal Declaration on Human Rights (Martinus Nijhoff, The Hague 1999) 523-550.

Ennew J., 'Time for Children or Time for Adults?' in Qvortrup J. et al (eds) Childhood Matters (Ashgate, Farnham 1994) 125-134.

Esteva G., 'Development' in Sachs W. (ed) The Development Dictionary (Zed Book, London 1992) 6-25.

Feinberg J., 'The Child's Right to an Open Future' In Aiken W. and LaFollette H. (eds) Whose Child? (Rowman and Littlefield, Totowa, New Jersey 1980) 124-153.

Franklin A. and Franklin B., 'Growing Pains: The Developing Children's Rights Movement in the UK' in Pilcher J and Wagg S (eds) Thatcher's Children? (Falmer Press, London 1996) 94-113. 
Freeman M., 'Towards a Sociology of Children's Rights' in Freeman M. (ed) Law and Childhood Studies (Oxford University Press, Oxford 2012) 29-38.

Jackson C., 'Rescue Gender From the Poverty Trap' in Jackson C. and Person R. (eds), Feminist Vision of Development - Gender Analysis and Policy (Routledge, London 1998) 3964.

Jaquette J. S and Staudt K., 'Women, Gender and Development' in Jaquette J. S. and Summerfield G. (eds), Women and Gender Equality in Development Theory and Practice (Duke University Press, Durham and London 2006) 17-52.

Jonsson U., 'A Human Rights-Based Approach to Programming' in Gready P. and Ensor J. (eds) Reinventing Development? (Zed Books, London 2005) 47-62.

Heintze H-J., 'Children's Rights within Human Rights Protection' in Freeman M. and Veerman P. (eds) The Ideologies of Children's Rights (Martinus Nijhoff Publishers, Dordrecht 1992) 71-78.

Hopkins B., 'What is Ontogenetic Development?' in Hopkins B. (ed) The Cambridge Encyclopedia of Child Development (Cambridge University Press, Cambridge 2005) 18-24.

James A. and Prout A., 'Re-presenting Childhood: Time and Transition in the Study of Childhood' in James A. and Prout A. Constructing and Reconstructing Childhood ( $2^{\text {nd }}$ edition, Routledge, London 1997) 230-250.

Kennedy D., 'Laws and Development' in Hatchard J. and Perry-Kessaris A. (eds) Law and Development: Facing Complexity in the $21^{\text {st }}$ Century (Cavendish, London 2003) 17-26.

King P. O, 'Thomas Hobbes's Children' in Turner S. T. and Matthews G. B. (eds) The Philosopher's Child (University of Rochester Press, Rochester 1998) 65-84.

Korczak J., 'How to Love a Child' in Wolins M. (ed) Selected works of Janusz Korczak (National Science Foundation, Washington D.C. 1967)355-356.

Kothari U., 'From Colonial Administration to Development Studies: A Post-Colonial Critique on the History of Development Studies', in Kothari U. (ed) A Radical History of Development Studies (Zed Books, New York 2005) 47-66.

Kritzer H. M., "'Research Is a Messy Business" - An Archeology of the Craft of Sociolegal research' in Halliday S. and Schmidt P. (eds) Conducting Law and Society Research (Cambridge University Press, Cambridge 2009) 264-285.

Lansdown G., 'International Developments in Children's Participation: Lessons and Challenges' in Tisdall K. et al (eds) Children, Young People and Social Inclusion (The Policy Press, Bristol 2006) 139-155.

Lansdown G., 'The Reporting Process Under the Convention on the Rights of the Child' in Alston P. and Crawford J. (eds) The Future of UN Human Rights Treaty Monitoring (Cambridge University Press, Cambridge 2000) 113-128.

Lopatka A., 'The Rights of the Child are Universal: The Perspective of the UN Convention on the Rights of the Child' in Freeman M. and Veerman P. (eds) The Ideologies of Children's 
Rights (Martinus Nijhoff Publishers, Dordrecht 1992) 47-52.

Maclure R., 'The Dynamics of Youth Participation: Insights from Research Fieldwork with Female Youth in Senegal' in Denov M. et al (eds) Children's Rights and International Development (Palgrave, New York 2011) 155-174.

Marshall, T.H., 'Citizenship and Social Class' in Marshall T.H., Citizenship and Social Class and Other Essays (Cambridge University Press, Cambridge 1951) 1-86.

Menghistu F., 'The Satisfaction of Survival Requirements' in Ramcharan B. G. (ed) The Right to Life in International Law (Martinus Nijhoff Publishers, Dordrecht 1985) 63-83.

Neill A. S., 'Freedom Works' in Adams P. et al (eds) Children's Rights (Elek Books, London 1971) $127-152$.

Nussbaum M., 'Human Capabilities, Female Human Beings' in Nussbaum M. and Glover J. (eds) Women, Culture and Development: A Study on Human Capabilities (Oxford University Press, Oxford 1995) 61-104.

Ollendorf R., 'The Rights of Adolescents' in Adams P. et al (eds) Children's Rights (Elek Books, London 1971) 91-126.

Pahuja J. F., 'Introduction' in Johns F. et al (eds) Events: The Force of International Law (Routledge, Oxford 2011) 1-17.

Palmeri A., 'Childhood's End: Toward the Liberation of Children' in Aiken W. and LaFollette H. (eds) Whose Child? (Rowman and Littlefield, Totowa, New Jersey 1980) 105-124.

Peleg N., 'What Do We Mean When We Speak About Children's Right to Development?' in Malekiam F. and Nordlöf K. (eds) The Sovereignty of Children in Law (Cambridge Scholarly Publishing, Cambridge 2012) 134-156.

Price Cohen C., 'Natural Law and Legal Positivism' in Freeman M. and Veerman P. (eds) The Ideologies of Children's Rights (Martinus Nijhoff Publishers, Dordrecht 1992) 53-70.

Prout A. and James A., 'A New Paradigm for the Sociology of Childhood? Provenance Promise and Problems' in James A. and Prout A. (eds) Constructing and Reconstructing Childhood ( $2^{\text {nd }}$ edition, Routledge, London 1997) 7-33.

Robertson P., 'Home as a Nest: Middle Class Childhood in Nineteenth-Century Europe' in deMause L. (ed) The History of Childhood (Souvenir Press, London 1976) 407-431.

Robinson M., 'What Rights Can Add to Good Development Practices?' in Alston P. and Robinson M. (eds) Human Rights and Development (Oxford University Press, Oxford 2005) $25-41$.

Rosas A., 'The Right to Development' in Eida A. et al (eds) Economic, Social and Cultural Rights ( $2^{\text {nd }}$ edition, Kluwer International, The Hague 2001) 119-130.

Sen A., 'Capabilities and Well-Being' in Nussbaum M. and Sen A. (eds) Quality of Life (Oxford University Press, Oxford 1993) 30-53. 
Sengupta A., 'Implementing the Right to Development' in Schrijver N. and Weiss F. (eds) International Law and Sustainable Development - Principles and Practice (Martinus Nijhoff Publishers, Leiden 2004) 341-377.

Simon J., 'Jean-Jacques Rousseau's Children', in Turner S. M. and Matthews G. B. (eds) The Philosopher's Child (University of Rochester Press, New York 1998) 105-120.

Woodhead M., 'Child Development and the Development of Childhood' in Jens Qvortrup et al (eds) The Palgrave Handbook of Childhood Studies (Palgrave, Basingstoke 2009, 2011).

\section{$\underline{\text { Journal Articles }}$}

Alderson P., 'Young Children's Human Rights: A Sociological Analysis' (2012) 20 International Journal of Children's Rights 177.

Alderson P. et al, 'The Participation Rights of Premature Babies' (2005) 13 International Journal of Children's Rights 31.

Alston A., 'A Third Generation of Solidarity Rights: Progressive Development or Obfuscation on International Human Rights Law?' (1982) 29 Netherlands International Law Review 307.

Alston P., 'Conjuring up New Human Rights: A Proposal for Quality Control' (1984) 78 American Journal of International Law 607.

Alston P., 'Making Space for New Human Rights: The Case of the Right to Development' (1988) 1 Harvard Human Rights Yearbook 3

Alston P., 'The Shortcomings of a "Garfield the Cat" Approach to the Right to Development' (1985) 15 California Western International Law Journal 510.

Anands S. and Sen A., 'The Income Component of the Human Development Index' (2000) 1 Journal of Human Development 83.

Archer R., 'The Strengths of Different Traditions: What Can Be Gained and What Might Be Lost By Combining Rights and Development?' (2006) 4 The International Journal of Human Rights 81.

Barash R. L., 'The Right to Development as a Human Right: Results of the Global Consultation' (1991) 13 Human Rights Quarterly 322.

Ben-Arieh A., 'The Child Indicators Movement: Past, Present, and Future' (2008) 1 Child Indicator Research 3.

Ben-Arieh A., 'Where Are the Children? Children's Role in Measuring and Monitoring Their Well-Being' (2005) 74 Social Indicators Research 573.

Ben-Arieh A. and Frønes I, 'Taxonomy for Child Well-Being Indicators: A Framework for the Analysis of the Well-Being of Children' (2011) 18 Childhood 460.

Bentley K. A., 'Can There Be Any Universal Children's Rights?' (2005) 9 International 
Journal of Children's Rights 107.

Bradshaw J. and Richardson D., 'An Index of Child Well-Being in Europe' (2009) 2 Children Indication Research 319.

Brietzke P. H., 'Consorting with the Chameleon, or Realizing the Right to Development' (1985) 15 California Western International Law Journal 560.

Burman E., 'Desiring Development? Psychoanalytic Contribution to Antidevelopmental Psychology' (2011) 24 International Journal of Qualitative Studies in Education 1.

Burman E., 'Deconstructing Neoliberal Childhood: Towards a Feminist Antipsychological Approach’ (2012) Childhood (Published online 17 May 2012.

Burman E., 'Local, Global or Globalized' (1996) 3 Childhood 46.

Buss E., 'What The Law Should (And Should Not) Learn From Child Development Research' (2009-2010) 38 Hofstra Law Review 13.

Butler U. M., 'Freedom, Revolt and 'Citizenship' (2009) 16 Childhood 11; See also Marcela Raffaelli, 'How Do Brazilian Street Youth Experience 'the Street'?' (2001) 8 Childhood 396.

Casas F., 'Children's Rights and Children's Quality of Life: Conceptual and Practical Issues' (1997) Social Indicators Research 283.

Camfield L. et al, 'What's the Use of 'Well-Being' in Contexts of Child Poverty? Approaches to Research, Monitoring and Children's Participation' (2009) 17 International Journal of Children's Rights 65.

Chinkin C., 'The Challenges of Soft Law: Development and Change in International law' (1989) 28 International and Comparative Law Quarterly 850.

Cohen C. P. and Wolthius A., 'The Committee on the Rights of the Child: $8^{\text {th }}$ Session Reports of States Parties' (1995) 3 International Journal of Children's Rights 263.

Cohen C. P. et al, 'Monitoring the United Nations Convention on the Rights of the Child: The Challenges of Information Management' (1996) 18 Human Rights Quarterly 439.

Cornwall A. and Nyamu-Musembi C., 'Putting the 'Rights-Based Approach' to Development into Practice' (2004) 25 Third World Quarterly 1415

Crivello G. et al, 'How Can Children Tell Us About Their Wellbeing? Exploring the Potential of Participatory Research Approaches within Young Lives' (2009) 90 Social Indicators Research 51.

Dekker J. J. J., 'The Century of the Child Revisited' (2000) 8 International Journal of Children's Rights 133.

Dixon R. and Nussbaum M., 'Children's Rights and a Capability Approach: The Question of Special Priority' (2011-2012) 97 Cornell Law Review 549.

Donnelly J., 'In Search of the Unicorn: The Jurisprudence and Politics of the Right to Development' (1985) 15 California Western International Law Journal 473. 
Dworkin R., 'Law as Interpretation' (1982) 9 Critical Inquiry 179.

Eichsteller G., 'Janusz Korczak - His Legacy and its Relevance for Children's Rights Today' (2009) 17 International Journal of Children's Rights 377, 385.

Etienne A-M. et al., 'The Gap Concept as a Quality of Life Measure: Validation Study of the Child Quality of Life Systemic Inventory’ (2011) 100 Social Indicators Research 241.

Falk R. A., 'On Treaty Interpretation and the New Heaven Approach: Achievements and Prospects' (1967-1968) 8 Virginia Journal of International Law 323.

Fass P.A, 'A Historical Context for the United Nations Convention on the Rights of the Child’ (2011) 633 ANNALS 17.

Federle K. H., 'Looking Ahead: An Empowerment Perspective on the Rights of the Child' (1995) 689 Temple Law Review 1585.

Federle K. H., 'Rights Flow Downhill' (1994) 2 International Journal of Children's Rights 343.

Fish S., 'Working on the Chain Gang: Interpretation on the Law and in Literary Criticism' (1982) 9 Critical Inquiry 201.

Freeman M., 'Children's Rights and Some Unanswered Questions and Some Unquestioned Answers' (1979-1980) 5 Poly Law Review 9, 15.

Freeman M., 'Rethinking Gillick' (2005) 13 International Journal of Children's Rights 201.

Freeman M., 'The Morality of Cultural Pluralism' (1995) 3 International Journal of Children's Rights 1.

Freeman M., 'The Human Rights of Children' (2010) 63 Current Legal Problems 1.

Freeman M., 'Why It Remains Important to Take Children's Rights Seriously' (2007) 15 International Journal of Children's Rights 5.

Gasper D., 'What Is the Capability Approach? Its Core, Rationale, Partners and Dangers' (2007) 36 Journal of Socio-Economics 335.

Geiser R. L., 'The Rights of Children' (1976-1977) 28 Hastings Law Journal 1027.

Goswami H., 'Social Relationships and Children's Subjective Well-Being' (2011) Social Indicator Research Online First 26.5.2011.

Grover S., 'A Response to K.A Bentley's 'Can There Be Any Universal Children's Rights?' (2007) 11 International Journal of Children's Rights 429

Hafen B. C., 'Children's Liberation and the New Egalitarianism: Some Reservations About Abandoning Youth to Their "Rights", [1976] BYU Law Review 605.

Hafen B. C. and Hafen J. O., 'Abandoning Children to their Autonomy: The United Nations Convention on the Rights o the Child' (1996) 37 Harvard International Law Journal 449. 
Hamilton L., 'A Theory of True Interests in the Work of Amartya Sen' (1999) Government and Opposition 516.

Hanafin S. et al, 'Achieving Consensus in Developing a National Set of Child Well-Being Indicators’ (2007) 80 Social Indicators Research 79.

Harris-Short S., 'International Human Rights Law: Imperialist, Inept and Ineffective? Cultural Relativism and the UN Convention on the Rights of the Child' (2003) 25 Human Rights Quarterly 130.

Hathaway O., 'Do Human Rights Treaties Make a Difference?' (2002) 111 Yale Law Journal 1935.

Holland S. et at, 'Power, Agency and Participatory Agenda: A Critical Exploration of Young's People's Engagement in Participative Qualitative Research' (2010) 17 Childhood 360.

Heesterman W., 'An Assessment of the Impact of Youth Submission on the United Nations Committee on the Rights of the Child' (2005) 13 International Journal of Children's Rights 351.

Heywood C., 'Centuries of Childhood: An Anniversary - And an Epitaph?' (2010) 3 Journal of History of Childhood and Youth 343, 357-358.

Himes J. R., 'Children's Rights: Moralists, Lawyers and the Right to Development' (1993) 1 International Journal of Children's Rights 81.

Hodgson D., 'The Child's Right to Life, Survival and Development' (1994) 2 International Journal of Children's Rights 369.

Ito T., 'New Education For Underprivileged Children: The Condition of Children's Rights in Japanese Law' (2012) 48 Paedagogica Historica 153.

Jacobs F. G., 'Varieties of Approach to Treaty Interpretation: With Special Reference to the Draft Convention on the Law of Treaties before the Vienna Diplomatic Conference' (1969) 18 International and Comparative Law Quarterly 318.

James A., 'Competition or Integration? The Next Step in Childhood Studies?' (2010) 17 Childhood 485.

James A., 'The Standardized Child: Issues of Openness, Objectivity and Agency in Promoting Childhood Health' (2004) 13 Anthropological Journal on European Culture 93.

Jans M., 'Children as Citizens' (2004) 11 Childhood 27.

Jones L. et al, 'Prevalence and Risk of Violence Against Children With Disabilities: A Systematic Review and Meta-analysis of Observational Studies' 2012 Lancet (12 July 2012 online edition).

Johnstone I., 'Treaty Interpretation: The Authority of Interpretive Community' (1990-1991) 12 Michigan Journal of International Law 371. 
Kahn-Freund O., 'On Uses and Misuses of Comparative Law' (1974) 37 Modern Law Review 1.

Karkness S., 'The Cultural Context of Child Development' (1980) 8 New Directions of Child Development 7.

Kelle H., '’Age Appropriate Development' As Measure and Norm' (2010 )17 Childhood 9.

Kella H., 'The Discourse of 'Development' - How 9 to 12-Year-Old Children Construct 'Childish' and 'Future Development' Identified Within Their Peer Culture' (2001) 8 Childhood 95.

Kennedy D., 'New Approaches to Comparative Law: Comparativism and International Governance' (1997) 2 Utah Law Review 545.

Land K. C. et al, 'Child and Youth Well-Being in the United States, 1975-1998: Some Findings from a New Index' (2001) 56 Social Indicators Research 241.

Legrand P., 'The Impossibility of 'Legal Transplants' (1997) 4 Maastricht Journal of European and Comparative Law 111.

Lindenmeyer K. and Sandin B., 'National Citizenship and Early Policies Shaping 'The Century of the Child' in Sweden and the United States' (2008) 1 Journal of History of Childhood and Youth 50.

Lippman L. H., 'Indicators and Indices of Child Well-Being: A Brief American History' (2007) 83 Social Indicators Research 39.

Lund R., 'At The Interface of Development Studies and Child Research: Rethinking Participating Child' (2007) 5 Children's Geographies 131.

Lundy L., 'Voice' is not enough: Conceptualising Article 12 of the UN Convention on the Rights of the Child' (2007) 33 British Educational Research Journal 927.

Margolin C. R., 'Salvation Versus Liberation: The Movement For Children's Rights in A Historical Context' (1977-1978) 25 Social Problems 441.

Marks S., 'The Human Right to Development: Between Rhetoric and Reality' (2004) 17 Harvard Human Rights Journal 137.

Marshall D., 'The Construction of Children as an Object On International Relations: the Declaration of Children's Rights and the Child Welfare Committee of League of Nations, 1990-1924' 7 (1999) International Journal of Children's Rights 103, 104.

Maurás M., 'Public Policies and Child Rights: Entering the Third Decade of the Convention on the Rights of the Child' (2011) 633 ANNALS 52.

McGillivray M. and White H., 'Measuring Development? The UNDP's Human Development Index' (1993) 5 Journal of International Development 183.

Minow M., 'What Ever Happened to Children's Rights' (1995-1996) 80 Minnesota Law Review 267. 
Modell J., 'How May Children's Development be Seen Historically?' (2000) 7 Childhood 81.

Moore A. and Crisp R., 'Welfarism in Moral Theory' (1996) 74 Australian Journal of Philosophy 598.

Moore A. et al, 'A Microdata Child Well-Being Index: Conceptualization, Creation and Findings' (2008) 1 ChildIndicator Research 17.

Morijn J., 'Reforming United Nations Human Rights Treaty Monitoring Reform' (2011) 29 Netherlands International Law Review 295, 309.

Nelson P. J. and Dorsey E., 'At the Nexus of Human Rights and Development: New Methods and Strategies of Global NGOs' (2003) 31 World Development 2013.

Nolan A., 'The Child as 'Democratic Citizen': Challenging the 'Participation Gap' (2010) 4 Public Law 767.

Nussbaum M., 'Capabilities as Fundamental Entitlements: Sen and Global Justice' (2003) 9 Feminist Economics 33.

Nussbaum M., 'Women's Capabilities and Social Justice' (2000) 1 Journal of Human Development 219.

O'Flaherty M., 'The Concluding Observations of United Nations Human Rights Treaty Bodies' (2006) Human Rights Law Review 27.

O'Manique J., 'Development, Human Rights and Law' (1992) 14 Human Rights Quarterly 383.

O'Manique J., 'Human Rights and Development' (1992) 14 Human Rights Quarterly 78.

Obiora L. A., 'Beyond the Rhetoric of a Right to Development' (1996) 18 Law \& Policy 355.

O’Neill O., 'Children's Rights and Children's Lives' (1988) 98 Ethics 445.

Palmer I., 'Rural Women and the Basic Needs Approach to Development' (1977) 115 International Labour Review 97.

Pavlovic Z. and Leban T. R, 'Children's Rights International Study Project (CRISP) - A Shift from the Focus on Children's Rights to a Quality of Life Assessment Instrument' (2009) 2 Child Indicators Research 265.

Perry-Kessaris A., 'Prepare Your Indicators: Economic Imperialism on the Shores of Law and Development' (2011) 7 International Journal of Law in Context 401.

Perry R. W., 'Rethinking the Right to Development: After the Critique of Development, After the Critique of Rights' (1996) 18 Law \& Society 225.

Pinkerton J., 'Children's Participation in the Policy Process: Some Thoughts on Policy Evaluation Based on the Irish National Children's Strategy' (2004) 18 Children \& Society 119.

Pressman S. and Summerfield G., 'The Economic Contribution of Amartya Sen' (2000) 12 
Review of Political Economy 89.

Ravallion M., 'Good and Bad Growth: The Human Development Reports' (1997) World Development 631.

Riss M., 'Treat Interpretation and ICJ Recourse to Travaux Préparatories: Towards a Proposal Amendment of Articles 31 and 32 of the Vienna Convention on the Law of Treaties' (1991) 14 Boston College International \& Comparative Law Review 111.

Rochelle V., 'White House Conferences on Children: an Historical Perspective' (1973) 43 Harvard Educational Review 653.

Roche J., 'Children: Rights, Participation and Citizenship' (1999) 6 Childhood 475.

Rodham H., 'Children Under the Law' (1973) 43 Harvard Educational Review 487.

Ruck M. D. et al, 'Children's and Adolescents' Understanding of Rights: Balancing Nurturance and Self-Determination' (1988) 64 Child Development 404.

Ruck M.S. et al, 'Adolescents' and Children's Knowledge About Their Rights: Some Evidence For How Young People View Rights In Their Own Lives' (1998) 21 Journal of Adolescence 275.

Sacco R., 'Legal Formants: A Dynamic Approach to Comparative Law' (1991)39 American Journal of Comparative Law 1.

Sagar A. D. and Najam A., 'The Human Development Index: A Critical Review' (1998) 25 Ecological Economy 249.

Saith A. and Wazir R., 'Towards Conceptualizing Child Well-being in India: The Need for a Paradigm Shift' (2010) 3 Children Indication Research 385.

Saito M., 'Amartya Sen's Capability Approach to Education: A Critical Exploration' (2003) 37 Journal of Philosophy of Education 17.

Sano H-T, 'Development and Human Rights: The Necessary, But Partial Integration of Human Rights and Development' (2000) 22 Human Rights Quarterly 734.

Sanson A. V. et al, 'The Development and Validation of Australian Indices of Child Development - Part I: Conceptualisation and Development' (2010) 3 Children Indication Research 275

Scherer L. P. and Hart S. N., 'Reporting to the UN Committee on the Rights of the Child Analyses of the First 49 State Party Reports on the Education Articles of the Convention on the Rights of the Child and a Proposition for an Experimental Reporting System for Education' (1999) 7 International Journal of Children's Rights 349.

Sen A., 'Human Rights and Capabilities' (2005) 6 Journal of Human Development 151.

Sen A., 'Children and Human Rights' (2007) 1 Indian Journal of Human Development 235, 241.

Sengupta A., 'The Human Right to Development' (2004) 32 Oxford Development Studies 
179.

Sengupta A., 'Realizing the Right to Development' (2000) 31 Development and Change 553

Shanahan S., 'Lost and Found: The Sociological Ambivalence Towards Childhood' (2007) 33 Annual Review of Sociology 407.

Shelton D., 'A Response to Donnelly and Alston' (1985) 15 California Western International Law Journal 524.

Skolnick A., 'The Limits of Childhood: Conceptions of Child Development and Social Context' (1975) 39 Law \& Contemporary Problems 38, 52-59.

Srinivasan T. N., 'Human Development: A New Paradigm or Reinvention of the Wheel?' (1994) 84 AEA Papers and Proceedings 238.

Stearns P. N., 'Defining Happy Childhoods: Assessing a Recent Change' (2010) 3 Journal of the History of Childhood and Youth 165.

Stewart J., "'The Dangerous Age of Childhood": Child Guidance and the "Normal" Child in Great Britain, 1920-1950’ (2011) 47 Paedagogica Historica 785.

Streeten P. and Burki S. J., 'Basic Needs: Some Issues' (1978) 6 World Development 411.

Thomas N., 'Towards A Theory Of Children's Participation' (2007) 15 International Journal of Children's Rights 199, 210.

Turner B., 'Personhood and Citizenship' (1986) 3 Theory Culture Society 1.

Uprichard E., 'Children As 'Being and Becomings: Children, Childhood and Temporality' (2008) 22 Children \& Society 303.

Vandenhole W., 'Economic, Social and Cultural Rights in the CRC: Is There a Legal Obligation to Cooperate Internationally for Development?" (2009) 17 International Journal of Children's Rights 23.

Van Drenth A. and Myers K., 'Normalising Childhood: Politics and Interventions Concerning Special Children in the United States and Europe (1900-1960)' (2011) 47 Paedagogica Historica 719.

Vann R. T, ‘The Youth of Centuries of Childhood' (1982) 21 History and Theory 279.

Vizard P., 'Specifying and Justifying a Basic Capability Set: Should the International Human Rights Framework be Given a More Direct Role?' (2007) 35 Oxford Development Studies 225.

Wald M. S., 'Children's Rights: A Framework for Analysis' (1979) 12 University California Davis Law Review 255.

Wall J., 'Can Democracy Represent Children? Towards a Politics of Difference' (2012) 19 Childhood 86.

Watson A., 'Comparative Law and Legal Change' (1978) 37 Cambridge Law Journal 313. 
Whelan D. J., Indivisible Human Rights (University of Pennsylvania Press, Philadelphia 2010).

Wilson A., 'The Infancy of the History of Childhood: An Appraisal of Philippe Aries' (1980) 19 History and Theory 132.

Woodhead M., 'Early Childhood Development: A Question of Rights' (2005) 37 International Journal of Early Childhood 80.

Woll L., 'Reporting to the UN Committee on the Rights of the Child: A Catalyst for Domestic Debate and Policy Change' (2000) 8 International Journal of Children's Rights 71.

Wolthuis A. and Allen D., 'Tenth Session of the Committee on the Rights of the Child: Consideration on State Party Reports' (1996) 4 International Journal of Children's Rights 69.

Woodhead M., 'Reconstructing Developmental Psychology - Some First Steps' (1999) 13 Children \& Society 3.

Woodhead M., 'Early Childhood Development: A Question of Rights' (2005) 37 International Journal of Early Childhood 80.

\section{$\underline{\text { Reports }}$}

Grant J. P., The State of the World's Children 1980-1981 (UNICEF, New York 1981).

Human Rights Watch, South Sudan: Step Up Urgent Human Rights Reforms (5 July 2012).

Melchiorre A. and Atkins E., At What Age Are School-Children Employed, Married and Taken to Court? (Right to Education Project, London 2011) 30-32.

Robeyns I., 'An Unworkable Idea or a Promising Alternative? Sen's Capability Approach Re-examined' (1993) Centre of Economic Discussion on Paper 00.30. University of Leuven, Mimeo.

UNDP, Human Development Report 1990 (Oxford University Press, New York 1990).

UNDP, Human Development Report - Human Rights and Human Development (Oxford University Press, Oxford and New York 2000).

UNICEF, The State of The World's Children 2011 (UNICEF, New York 2011).

\section{$\underline{\text { Cases }}$}

\section{$\underline{\text { United Kingdom }}$}

Gillick v. West Norfolk and Wisbech Area Health Authority [1986] AC 112. 
United States of America

In Re Gault, 387 U.S. 1 (1967).

Roper V. Simmons 543 U.S 551 (2005).

Graham V. Florida 560 U.S _ (2010).

Miller V. Alabama 567 U.S _ (2012).

\section{$\underline{\text { International Convention and Declarations }}$}

The Covenant of the League of Nations, 1924.

The Declaration on the Rights of the Child, League of Nations O.J. Spec. Supp. 21, at 43 (1924).

Charter of the United Nations (1945).

UNGA, Universal Declaration of Human Rights, 10 December 1948, 217 A (III).

Declaration on the Rights of the Child (Adopted by UN General Assembly Resolution 1386 (XIV) of 10 December 1959).

The Declaration on the Right to Development, adopted by General Assembly Resolution 41/128 of 4 December 1986.

The International Covenant on Civil and Political Rights, Adopted and opened to signature, ratification and accession by General Assembly Resolution 2200A (XXI) of 16 December 1996. Entered into force on 23 March 1976.

The International Covenant on Economic, Social and Cultural Rights, Adopted and opened to signature, ratification and accession by General Assembly Resolution 2200A (XXI) of 16 December 1966. Enter into force on 3 January 1976.

Vienna Convention on the Laws of Treaties (Done at Vienna on 23 May 1969, Entered into Force on 27 January 1980). United Nations Treaty Series, Vol. 1155, 331.

UN Convention on the Rights of the Child 1989 (Adopted by General Assembly Resolution 44/25 of 20 November 1989, entered into force on 2 September 1990).

African Charter on the Rights and Welfare of the Child (OAU Doc. CAB/LEG/24.9/49 (1990)), entered into force Nov. 29, 1999.

UNGA, Vienna Declaration and Program of Action (12 July 1993), UN Doc A/CONF.157/23. 


\section{$\underline{\text { UN Documents }}$}

General Assembly Resolution 31/169, adopted on 21 December 1976.

General Assembly Resolution 31/169, 'International Year of the Child' adopted on 21 December 1976.

UN Commission on Human Rights Resolution 4 (XXXIII) of 21 February 1977.

Letter from the Permanent representative of Poland to the United Nations Office at Geneva E/CN.4/1284 (18 January 1978).

UN Economic and Social Council (18 January 1978) UN Doc E/CN.4/1284.

UN Economic and Social Council, 'Question of A Convention on the Rights of the Child' (23 February 1978), UN Doc E/CN.4/NGO/225.

UNGA Resolution 50/155 of 21 December 1995 (entered into force on 18 November 2002).

\section{UN Documents - Open Ended Working Group on the UN Convention on the Rights of the Child}

UNHCR, 'Question of a Convention on the Rights of the Child' (7 February 1978) UN Docs E/CN.4/L.1366.

UNHCR, 'Question on a Convention on the Rights of the Child' (6 February - 10 March 1978) UN Doc E/1978/34/E/CN.4/1292, p. 4.

UNHCR, 'Summary Record of the $1438^{\text {th }}$ Meeting' (15 February 1978) UN Doc E/CN.4/SR.1438.

UNHCR, 'Summary Record of the $1471^{\text {st }}$ Meeting' (13 March 1978) UN Doc E/CN.4/SR.1471, 11.

UNHCR, 'Question of a Convention on the Rights of the Child' (1 February 1979) UN Doc E/CN.4/1324/Add. 1.

General comments by specialized agencies on the first Polish draft - annexed to Commission on Human Rights resolution 20 (XXXIV) of 8 March 1978 (27 December 1978) UN Doc E/CN.4/1324.

UNHCR, 'Report of the Open-Ended Working Group on a Draft Convention on the Rights of the Child' (12 March 1979) UN Doc E/CN.4/L.1468.

UNHCR, 'Report of the Working Group on a Draft Convention on the Rights of the Child' (10 March 1980) UN Doc E/CN.4/L.1542.

UNHCR, 'Report of the Working Group on a Draft Convention on the Rights of the Child' (17 February 1981) UN Doc E/CN.4/L.1975.

UNHCR, 'Report of the Working Group on a Draft Convention on the Rights of the Child' (8 
March 1982) UN Doc E/CN.4/1982/30/Add. 1.

UNHCR, 'Report of the Working Group on a Draft Convention on the Rights of the Child' (25 March 1983) UN Doc E/CN.4/1983/62.

UNHCR, 'Report of the Working Group on a Draft Convention on the Rights of the Child' (23 February 1984) UN Doc E/CN.4/1984/71.

UNHCR, 'Report of the Working Group on a Draft Convention on the Rights of the Child' (11 March 1985) UN Doc E/CN.4/1985/L.1.

UNHCR, 'Report of the Working Group on a Draft Convention on the Rights of the Child' (13 March 1986) UN Doc E/CN.4/1986/39.

UNHCR, 'Report of the Working Group on a Draft Convention on the Rights of the Child' (23 February 1987) UN Doc E/CN.4/1987/25.

UNHCR, 'Pre-Sessional Open-Ended Working Group on the Question of a Convention on the Rights of the Child, 'Proposal Submitted By India'(28 January 1988) UN Doc E/CN.4/1988/WG1/WG.13.

UNHCR, 'Report of the Working Group on a Draft Convention on the Rights of the Child' (6 April 1988) UN Doc E/CN.4/1988/28.

UNHCR, 'Report of the Working Group on a Draft Convention on the Rights of the Child' (2 March 1989) UN Doc E/CN.4/1989/48.

UNHCR, 'Draft Convention on the Rights of the Child, Working Paper Submitted by the Chairman, Text as Adopted at First Reading With Suggested Revisions' (24 November 1988) UN Doc E/CN.4/1989/WG.1/WP.2.

\section{UN Committee on the Rights of the Child}

\section{$\underline{\text { General Documents }}$}

UNCRC, 'General Guidelines Regarding Forms and Content of Initial Reports to be Submitted by States Parties Under Article 44(1)(a) of the Convention' (30 October 1991) UN Docs $\mathrm{CRC} / \mathrm{C} / 5$.

UNCRC, 'Overview of the Reporting Procedures' (24 October 1994) UN Docs CRC/C/33.

UNCRC, 'General Guidelines Regarding the Forms and Content of Period Reports to be Submitted by States Parties Under Article 44(1)(b) of the Convention' (29 November 2005) CRC/C/58/Rev. 1.

\section{$\underline{\text { List of Issues }}$}

UNCRC, 'Consideration of Reports Submitted by States Parties Under Article 44 of the Convention - El Salvador' (23 July 2009) UN Docs CRC/C/SLV/3-4, 7 [21 February 2008]. 
UNCRC, 'Consideration of Reports Submitted by States Parties Under Article 44 of the Convention - Japan' (25 September 2009) UN Docs CRC/C/JPN/3 [22 April 2008]. UNCRC, 'Consideration of Reports Submitted by States Parties Under Article 44 of the Convention - Mongolia' (9 June 2009) UN Docs CRC/C/MNG/3-4 [31 March 2008].

UNCRC, 'Consideration of Reports Submitted by States Parties Under Article 44 of the Convention - Grenada' (7 August 2009) UN Docs CRC/C/GRD/2 [26 May 2008].

UNCRC, 'Consideration of Reports Submitted by States Parties Under Article 44 of the Convention - Spain' (20 November 2009) UN Docs CRC/C/ESP/3-4 [30 May 2008].

UNCRC, 'Consideration of Reports Submitted by States Parties Under Article 44 of the Convention - Burkina Faso' (30 March 2009) UN Docs CRC/C/BFA/3-4 [21 June 2008].

UNCRC, 'Consideration of Reports Submitted by States Parties Under Article 44 of the Convention - Sudan' (24 February 2010) UN Docs CRC/C/SDN/3-4 [27 June 2008].

UNCRC, 'Consideration of Reports Submitted by States Parties Under Article 44 of the Convention - Belgium' (4 December 2009) UN Docs CRC/C/BEL/3-4 [15 July 2008].

UNCRC, 'List of Issues Related to the Consideration the Third and Fourth Report of El Salvador (2 November 2009) UN Docs CRC/C/SLV/Q/3-4.

UNCRC, 'List of Issues Concerning Additional and Updated Information Related to the Consideration of the Combined Second to Forth Periodic Reports of Angola' (18 June 2010) UN Docs CRC/C/AGO/Q/2-4.

UNCRC, 'List of Issues Related to the Consideration the Third and Forth Periodic Reports of Belgium' (8 March 2010) UN Docs CRC/C/BLG/Q/3-4.

UNCRC, 'List of Issues Related to the Consideration the Third Periodic Reports of Japan' (5 February 2010) UN Docs CRC/C/JPN/Q/3.

\section{$\underline{\text { General Comments }}$}

UNCRC 'General Comment Number 1 - Article 29(1): The Aims of Education' (17 April 2001) UN Doc CRC/GC/1/2001.

UNCRC 'General Comment Number 2 - The Role of Independent National Human Rights Institutions in the Promotion and Protection of the Rights of the Child' (15 November 2002) UN Doc CRC/GC/2/2002.

UNCRC 'General Comment Number 3 - HIV/AIDS and the Rights of the Child' (17 March 2003) UN Doc CRC/GC/3/2003.

UNCRC 'General Comment Number 4- Adolescent Health and Development in the Context of the Convention on the Rights of the Child' (1 July 2003) UN Doc CRC/GC/4/2003.

UNCRC 'General Comment Number 5 - General Measures of Implementations of the Convention on the Rights of the Child' (27 November 2003) UN Doc CRC/GC/5/2003. 
UNCRC 'General Comment Number 6 - Treatment of Unaccompanied and Separated Children Outside Their Country of Origin' (1 September 2005) UN Doc CRC/GC/2005/6.

UNCRC 'General Comment Number 7 - Implementing Child Rights in Early Childhood' (20 September 2006) UN Doc CRC/GC/2006/7/Rev.1.

UNCRC 'General Comment Number 8 - The Rights of the Child for Protection From Corporal Punishment and other Cruel or Degrading Forms of Punishment' (2 March 2007) $\mathrm{UN}$ Doc CRC/GC/8.

UNCRC 'General Comment Number 9 - The Rights of Children with Disabilities' (27 February 2007) UN Doc CRC/C/GC/9.

UNCRC 'General Comment Number 10 - Children's Rights in Juvenile Justice' (25 April 2007) UN Doc CRC/C/GC/10.

UNCRC 'General Comment Number 11 - Indigenous Children and their Rights under the Convention' (12 February 2009) UN Doc CRC/C/GC/11.

UNCRC 'General Comment Number 12 - The Rights of the Child to be Heard' (20 July 2009) UN Doc CRC/C/GC/12.

UNCRC 'General Comment Number 13 - The Right of the Child to Freedom from all Forms of Violence' (18 April 2011) UN Doc CRC/C/GC/13.

\section{Concluding Observations}

UNCRC 'Concluding Observations: Bolivia' (18 February 1993) UN Doc CRC/C/15/Add.1.

UNCRC 'Concluding Observations: Sweden' (18 February 1993) UN Doc CRC/C/15/Add. 2 .

UNCRC 'Concluding Observations: Viet Nam' (18 February 1993) UN Doc CRC/C/15/Add. 3.

UNCRC 'Concluding Observations: Russian Federation' (18 February 1993) UN Doc CRC/C/15/Add.4.

UNCRC 'Concluding Observations: Egypt' (18 February 1993) UN Doc CRC/C/15/Add.5.

UNCRC 'Concluding Observations: Indonesia' (18 October 1993) UN Doc CRC/C/15/Add.7.

UNCRC 'Concluding Observations: El Salvador' (18 October 1993) UN Doc CRC/C/15/Add.9.

UNCRC ‘Concluding Observations: Sudan’ (18 October 1993) UN Doc CRC/C/15/Add.10.

UNCRC 'Concluding Observations: Costa Rica' (18 October 1993) UN Doc 
CRC/C/15/Add.11.

UNCRC 'Concluding Observations: Rwanda' (18 October 1993) UN Doc CRC/C/15/Add.12.

UNCRC 'Concluding Observations: Romania' (7 February 1994) UN Doc CRC/C/15/Add.17.

UNCRC 'Concluding Observations: Mexico’ (7 February 1994) UN Doc CRC/C/15/Add.13.

UNCRC 'Concluding Observations: Namibia' (7 February 1994) UN Doc CRC/C/15/Add. 14.

UNCRC 'Concluding Observations: Colombia' (7 February 1994) UN Doc CRC/C/15/Add. 15.

UNCRC 'Concluding Observations: Romania' (7 February 1994) UN Doc CRC/C/15/Add. 16.

UNCRC ‘Concluding Observations: Belarus’ (7 February 1994) UN Doc CRC/C/15/Add. 17.

UNCRC ‘Concluding Observations: Pakistan’ (29 April 1994) UN Doc CRC/C/15/Add. 18.

UNCRC 'Concluding Observations: Burkina Faso' (25 April 1994) UN Doc CRC/C/15/Add. 19.

UNCRC ‘Concluding Observations: France’ (25 April 1994) UN Doc CRC/C/15/Add. 20.

UNCRC 'Concluding Observations: Jordan’ (25 April 1994) UN Doc CRC/C/15/Add. 21.

UNCRC 'Concluding Observations: Chile' (25 April 1994) UN Doc CRC/C/15/Add. 22.

UNCRC 'Concluding Observations: Norway’ (25 April 1994) UN Doc CRC/C/15/Add. 23.

UNCRC 'Concluding Observations: Honduras' (24 October 1994) UN Doc CRC/C/15/Add. 24.

UNCRC 'Concluding Observations: Indonesia' (24 October 1994) UN Doc CRC/C/15/Add. 25.

UNCRC 'Concluding Observations: Madagascar' (24 October 1994) UN Doc CRC/C/15/Add. 26.

UNCRC 'Concluding Observations: Paraguay' (24 October 1994) UN Doc CRC/C/15/Add. 27.

UNCRC ‘Concluding Observations: Spain’ (24 October 1994) UN Doc CRC/C/15/Add. 28.

UNCRC 'Concluding Observations: Philippines' (15 February 1995) UN Doc CRC/C/15/Add. 29.

UNCRC 'Concluding Observations: Columbia' (15 February 1995) UN Doc CRC/C/15/Add. 30 . 
UNCRC 'Concluding Observations: Poland' (15 January 1995) UN Doc CRC/C/15/Add. 31.

UNCRC 'Concluding Observations: Jamaica' (15 February 1995) UN Doc CRC/C/15/Add. 32.

UNCRC 'Concluding Observations: Denmark' (15 February 1995) UN Doc CRC/C/15/Add. 33.

UNCRC 'Concluding Observations: United Kingdom' (15 February 1995) UN Doc CRC/C/15/Add. 34.

UNCRC 'Concluding Observations: Argentina' (15 February 1995) UN Doc CRC/C/15/Add. 35 .

UNCRC 'Concluding Observations: Nicaragua’ (20 June 1995) UN Doc CRC/C/15/Add. 36.

UNCRC 'Concluding Observations: Canada' (20 June 1995) UN Doc CRC/C/15/Add. 37.

UNCRC 'Concluding Observations: Belgium’ (20 June 1995) UN Doc CRC/C/15/Add. 38.

UNCRC ‘Concluding Observations: Tunisia’ (21 June 1995) UN Doc CRC/C/15/Add. 39.

UNCRC 'Concluding Observations: Sri Lanka' (21 June 1995) UN Doc CRC/C/15/Add. 40.

UNCRC 'Concluding Observations: Italy’ (27 November 1995) UN Doc CRC/C/15/Add. 41.

UNCRC 'Concluding Observations: Ukraine' (27 November 1995) UN Doc CRC/C/15/Add. 42 .

UNCRC 'Concluding Observations: Germany' (27 November 1995) UN Doc CRC/C/15/Add. 43.

UNCRC 'Concluding Observations: Senegal' (27 November 1995) UN Doc CRC/C/15/Add. 44.

UNCRC 'Concluding Observations: Portugal' (27 November 1995) UN Doc CRC/C/15/Add. 45.

UNCRC 'Concluding Observations: Holy See' (27 November 1995) UN Doc CRC/C/15/Add. 46.

UNCRC 'Concluding Observations: Yemen' (13 February 1996) UN Doc CRC/C/15/Add. 47.

UNCRC 'Concluding Observations: Mongolia' (13 February 1996) UN Doc CRC/C/15/Add. 48.

UNCRC 'Concluding Observations: Former Republic of Yugoslavia (Serbia and Montenegro)' (13 February 1996) UN Doc CRC/C/15/Add. 49.

UNCRC 'Concluding Observations: Iceland' (13 February 1996) UN Doc CRC/C/15/Add. 50 . 
UNCRC 'Concluding Observations: Republic of Korea' (13 February 1996) UN Doc CRC/C/15/Add. 51.

UNCRC 'Concluding Observations: Croatia' (13 February 1996) UN Doc CRC/C/15/Add. 52.

UNCRC 'Concluding Observations: Finland' (13 February 1996) UN Doc CRC/C/15/Add. 53.

UNCRC ‘Concluding Observations: Lebanon’ (7 June 1996) UN Doc CRC/C/15/Add. 54.

UNCRC 'Concluding Observations: Zimbabwe’ (7 June 1996) UN Doc CRC/C/15/Add. 55.

UNCRC 'Concluding Observations: China' (7 June 1996) UN Doc CRC/C/15/Add. 56.

UNCRC 'Concluding Observations: Nepal' (7 June 1996) UN Doc CRC/C/15/Add. 57.

UNCRC 'Concluding Observations: Guatemala' (7 June 1996) UN Doc CRC/C/15/Add. 58.

UNCRC ‘Concluding Observations: Cyprus’ (7 June 1996) UN Doc CRC/C/15/Add. 59.

UNCRC 'Concluding Observations: Morocco' (30 October 1996) UN Doc CRC/C/15/Add. 60 .

UNCRC 'Concluding Observations: Nigeria’ (30 October 1996) UN Doc CRC/C/15/Add. 61.

UNCRC 'Concluding Observations: Uruguay' (30 October 1996) UN Doc CRC/C/15/Add. 62.

UNCRC 'Concluding Observations: United Kingdom (Hong Kong)' (30 October 1996) UN Doc CRC/C/15/Add. 63.

UNCRC 'Concluding Observations: Mauritius' (30 October 1996) UN Doc CRC/C/15/Add. 64.

UNCRC 'Concluding Observations: Slovenia' (30 October 1996) UN Doc CRC/C/15/Add. 65 .

UNCRC 'Concluding Observations: Bulgaria' (24 January 1997) UN Doc CRC/C/15/Add. 66.

UNCRC 'Concluding Observations: Ethiopia' (24 January 1997) UN Doc CRC/C/15/Add. 67.

UNCRC ‘Concluding Observations: Panama’ (24 January 1997) UN Doc CRC/C/15/Add. 68.

UNCRC 'Concluding Observations: Myanmar' (24 January 1997) UN Doc CRC/C/15/Add. 69.

UNCRC 'Concluding Observations: Syria Arab Republic' (24 January 1997) UN Doc CRC/C/15/Add. 70.

UNCRC 'Concluding Observations: New Zealand' (24 January 1997) UN Doc 
CRC/C/15/Add. 71.

UNCRC ‘Concluding Observations: Cuba’ (18 June 1997) UN Doc CRC/C/15/Add. 72.

UNCRC 'Concluding Observations: Ghana’ (18 June 1997) UN Doc CRC/C/15/Add. 73.

UNCRC ‘Concluding Observations: Bangladesh' (18 June 1997) UN Doc CRC/15/C/Add. 74.

UNCRC ‘Concluding Observations: Paraguay’ (18 June 1997) UN Doc CRC/C/15/Add. 75.

UNCRC 'Concluding Observations: Algeria' (18 June 1997) UN Doc CRC/C/15/Add. 76.

UNCRC 'Concluding Observations: Azerbaijan’ (17 June 1997) UN Doc CRC/C/15/Add. 77.

UNCRC ‘Concluding Observations: Laos’ (10 October 1997) UN Doc CRC/C/15/Add. 78.

UNCRC 'Concluding Observations: Australia' (10 October 1997) UN Doc CRC/C/15/Add. 79.

UNCRC 'Concluding Observations: Uganda' (21 October 1997) UN Doc CRC/C/15/Add. 80 .

UNCRC 'Concluding Observations: Czech Republic' (27 October 1997) UN Doc CRC/C/15/Add. 81.

UNCRC 'Concluding Observations: Trinidad and Tobago' (10 October 1997) UN Doc CRC/C/15/Add. 82.

UNCRC ‘Concluding Observations: Togo’ (10 October 1997) UN Doc CRC/C/15/Add. 83.

UNCRC 'Concluding Observations: Libya Arab Jamahiriya' (4 February 1998) UN Doc CRC/C/15/Add. 84.

UNCRC 'Concluding Observations: Ireland’ (4 February 1998) UN Doc CRC/C/15/Add. 85.

UNCRC 'Concluding Observations: Federated State of Micronesia' (4 February 1998) UN Doc CRC/C/15/Add. 86.

UNCRC ‘Concluding Observations: Hungary’ (5 June 1998) UN Doc CRC/C/15/Add. 87.

UNCRC 'Concluding Observations: Democratic People's Republic of Korea' (5 June 1998) UN Doc CRC/C/15/Add. 88.

UNCRC ‘Concluding Observations: Fiji’ (24 June 1998) UN Doc CRC/C/15/Add. 89.

UNCRC ‘Concluding Observations: Japan’ (5 June 1998) UN Doc CRC/C/15/Add. 90.

UNCRC ‘Concluding Observations: Maldives’ (5 June 1998) UN Doc CRC/C/15/Add. 91.

UNCRC 'Concluding Observations: Luxemburg' (24 June 1998) UN Doc CRC/C/15/Add. 92. 
UNCRC 'Concluding Observations: Ecuador' (26 October 1998) UN Doc CRC/C/15/Add. 93.

UNCRC ‘Concluding Observations: Iraq’ (26 October 1998) UN Doc CRC/C/15/Add. 94.

UNCRC 'Concluding Observations: Bolivia’ (26 October 1998) UN Doc CRC/C/15/Add. 95.

UNCRC 'Concluding Observations: Kuwait’ (26 October 1998) UN Doc CRC/C/15/Add. 96.

UNCRC 'Concluding Observations: Thailand' (26 October 1998) UN Doc CRC/C/15/Add. 97.

UNCRC 'Concluding Observations: Austria’ (7 May 1999) UN Doc CRC/C/15/Add. 98.

UNCRC 'Concluding Observations: Belize’ (10 May 1999) UN Doc CRC/C/15/Add. 99.

UNCRC 'Concluding Observations: Guinea’ (10 May 1999) UN Doc CRC/C/15/Add. 100.

UNCRC ‘Concluding Observations: Sweden’ (10 May 1999) UN Doc CRC/C/15/Add. 101.

UNCRC ‘Concluding Observations: Yemen’ (10 May 1999) UN Doc CRC/C/15/Add. 102.

UNCRC 'Concluding Observations: Barbados' (24 August 1999) UN Doc CRC/C/15/Add. 103.

UNCRC 'Concluding Observations: St. Kitts and Nevis' (24 August 1999) UN Doc CRC/C/15/Add. 104.

UNCRC 'Concluding Observations: Honduras' (24 August 1999) UN Doc CRC/C/15/Add. 105.

UNCRC ‘Concluding Observations: Benin’ (24 August 1999) UN Doc CRC/C/15/Add. 106.

UNCRC ‘Concluding Observations: Chad’ (24 August 1999) UN Doc CRC/C/15/Add. 107.

UNCRC 'Concluding Observations: Nicaragua' (24 August 1999) UN Doc CRC/C/15/Add. 108.

UNCRC 'Concluding Observations: Venezuela' (2 November 1999) UN Doc CRC/C/15/Add. 109.

UNCRC 'Concluding Observations: Russian Federation' (10 November 1999) UN Doc CRC/C/15/Add. 110.

UNCRC 'Concluding Observations: Vanuatu’ (10 November 1999) UN Doc CRC/C/15/Add. 111.

UNCRC ‘Concluding Observations: Mexico’ (10 November 1999) UN Doc CRC/C/15/Add. 112.

UNCRC ‘Concluding Observations: Mali’ (2 November 1999) UN Doc CRC/C/15/Add. 113. UNCRC 'Concluding Observations: Netherlands' (26 October 1999) UN Doc 
CRC/C/15/Add. 114.

UNCRC 'Concluding Observations: India’ (23 February 2000) UN Doc CRC/C/15/Add. 115.

UNCRC 'Concluding Observations: Sierra Leon' (24 February 2000) UN Doc CRC/C/15/Add. 116.

UNCRC 'Concluding Observations: Costa Rica' (24 February 2000) UN Doc CRC/C/15/Add. 117.

UNCRC 'Concluding Observations: Macedonia' (23 February 2000) UN Doc CRC/C/15/Add. 118.

UNCRC 'Concluding Observations: Armenia' (24 February 2000) UN Doc CRC/C/15/Add. 119.

UNCRC 'Concluding Observations: Peru’ (22 February 2000) UN Doc CRC/C/15/Add. 120.

UNCRC 'Concluding Observations: Grenada' (28 February 2000) UN Doc CRC/C/15/Add. 121.

UNCRC 'Concluding Observations: South Africa' (23 February 2000) UN Doc CRC/C/15/Add. 122.

UNCRC 'Concluding Observations: Islamic Republic of Iran' (28 February 2000) UN Doc CRC/C/15/Add. 123.

UNCRC 'Concluding Observations: Georgia' (28 June 2000) UN Doc CRC/C/15/Add. 124.

UNCRC ‘Concluding Observations: Jordan’ (28 June 2000) UN Doc CRC/C/15/Add. 125.

UNCRC 'Concluding Observations: Norway’ (28 June 2000) UN Doc CRC/C/15/Add. 126.

UNCRC ‘Concluding Observations: Kyrgyzstan’ (9 August 2000) UN Doc CRC/C/15/Add. 127.

UNCRC 'Concluding Observations: Cambodia' (28 June 2000) UN Doc CRC/C/15/Add. 128.

UNCRC ‘Concluding Observations: Malta’ (28 June 2000) UN Doc CRC/C/15/Add. 129.

UNCRC 'Concluding Observations: Suriname’ (28 June 2000) UN Doc CRC/C/15/Add. 130.

UNCRC 'Concluding Observations: Djibouti’ (28 June 2000) UN Doc CRC/C/15/Add. 131.

UNCRC 'Concluding Observations: Finland' (16 October 2000) UN Doc CRC/C/15/Add. 132.

UNCRC 'Concluding Observations: Burundi' (16 October 2000) UN Doc CRC/C/15/Add. 133.

UNCRC 'Concluding Observations: UK (Isle of Man)' (16 October 2000) UN Doc CRC/C/15/Add. 134. 
UNCRC 'Concluding Observations: UK (OT)' (16 October 2000) UN Doc CRC/C/15/Add. 135.

UNCRC 'Concluding Observations: Tajikistan' (23 October 2000) UN Doc CRC/C/15/Add. 136.

UNCRC 'Concluding Observations: Columbia' (16 October 2000) UN Doc CRC/C/15/Add. 137.

UNCRC 'Concluding Observations: Central African Republic' (18 October 2000) UN Doc CRC/C/15/Add. 138.

UNCRC 'Concluding Observations: Marshal Island' (16 October 2000) UN Doc CRC/C/15/Add. 139.

UNCRC 'Concluding Observations: Slovakia' (23 October 2000) UN Doc CRC/C/15/Add. 140.

UNCRC 'Concluding Observations: Comoros' (23 October 2000) UN Doc CRC/C/15/Add. 141.

UNCRC 'Concluding Observations: Latvia' (21 February 2000) UN Doc CRC/C/15/Add. 142.

UNCRC 'Concluding Observations: Liechtenstein' (21 February 2000) UN Doc CRC/C/15/Add. 143.

UNCRC 'Concluding Observations: Ethiopia' (21 February 2000) UN Doc CRC/C/15/Add. 144.

UNCRC 'Concluding Observations: Egypt' (21 February 2000) UN Doc CRC/C/15/Add. 145 .

UNCRC 'Concluding Observations: Lithuania' (21 February 2000) UN Doc CRC/C/15/Add. 146.

UNCRC 'Concluding Observations: Lesotho' (21 February 2000) UN Doc CRC/C/15/Add. 147.

UNCRC 'Concluding Observations: Saudi Arabia' (21 February 2000) UN Doc CRC/C/15/Add. 148.

UNCRC 'Concluding Observations: Palau' (21 February 2000) UN Doc CRC/C/15/Add. 149.

UNCRC 'Concluding Observations: Dominic Republic' (21 February 2000) UN Doc CRC/C/15/Add. 150.

UNCRC 'Concluding Observations: Denmark’ (10 July 2001) UN Doc CRC/C/15/Add. 151.

UNCRC ‘Concluding Observations: Turkey’ (9 July 2001) UN Doc CRC/C/15/Add. 152.

UNCRC 'Concluding Observations: Democratic Republic of Congo’ (9 July 2001) UN Doc 
CRC/C/15/Add. 153.

UNCRC ‘Concluding Observations: Guatemala’ (9 July 2001) UN Doc CRC/C/15/Add. 154.

UNCRC 'Concluding Observations: Ivory Coast' (9 July 2001) UN Doc CRC/C/15/Add. 155.

UNCRC 'Concluding Observations: United Republic of Tanzania' (9 July 2001) UN Doc CRC/C/15/Add. 156.

UNCRC ‘Concluding Observations: Bhutan’ (9 July 2001) UN Doc CRC/C/15/Add. 157.

UNCRC ‘Concluding Observations: Monaco’ (9 July 2001) UN Doc CRC/C/15/Add. 158.

UNCRC 'Concluding Observations: Mauritania' (6 November 2001) UN Doc CRC/C/15/Add. 159.

UNCRC 'Concluding Observations: Kenya' (7 November 2001) UN Doc CRC/C/15/Add. 160.

UNCRC 'Concluding Observations: Oman' (6 November 2001) UN Doc CRC/C/15/Add. 161.

UNCRC 'Concluding Observations: Portugal' (6 November 2001) UN Doc CRC/C/15/Add. 162.

UNCRC 'Concluding Observations: Qatar' (6 November 2001) UN Doc CRC/C/15/Add. 163.

UNCRC 'Concluding Observations: Cameroon' (6 November 2001) UN Doc CRC/C/15/Add. 164.

UNCRC 'Concluding Observations: Gambia' (6 November 2001) UN Doc CRC/C/15/Add. 165.

UNCRC 'Concluding Observations: Paraguay' (6 November 2001) UN Doc CRC/C/15/Add. 166.

UNCRC 'Concluding Observations: Uzbekistan' (7 November 2001) UN Doc CRC/C/15/Add. 167.

UNCRC 'Concluding Observations: Cape Verde' (7 November 2001) UN Doc CRC/C/15/Add. 168.

UNCRC 'Concluding Observations: Lebanon' (1 February 2002) UN Doc CRC/C/15/Add. 169.

UNCRC 'Concluding Observations: Greece’ (2 April 2002) UN Doc CRC/C/15/Add. 170.

UNCRC 'Concluding Observations: Gabon' (1 February 2002) UN Doc CRC/C/15/Add. 171.

UNCRC 'Concluding Observations: Mozambique' (7 February 2002) UN Doc 
CRC/C/15/Add. 172.

UNCRC 'Concluding Observations: Chile’ (3 April 2002) UN Doc CRC/C/15/Add. 173.

UNCRC 'Concluding Observations: Malawi’ (2 April 2002) UN Doc CRC/C/15/Add. 174.

UNCRC ‘Concluding Observations: Bahrain' (11 March 2002) UN Doc CRC/C/15/Add. 175.

UNCRC 'Concluding Observations: Andorra' (11 March 2002) UN Doc CRC/C/15/Add. 176.

UNCRC 'Concluding Observations: Guinea-Bissau' (13 June 2002) UN Doc CRC/C/15/Add. 177.

UNCRC ‘Concluding Observations: Belgium’ (13 June 2002) UN Doc CRC/C/15/Add. 178.

UNCRC ‘Concluding Observations: Niger’ (13 June 2002) UN Doc CRC/C/15/Add. 179.

UNCRC ‘Concluding Observations: Belarus’ (13 June 2002) UN Doc CRC/C/15/Add. 180.

UNCRC 'Concluding Observations: Tunisia’ (13 June 2002) UN Doc CRC/C/Add. 181.

UNCRC 'Concluding Observations: Switzerland' (13 June 2002) UN Doc CRC/C/15/Add. 182.

UNCRC 'Concluding Observations: United Arab Emirates' (13 June 2002) UN Doc CRC/C/15/Add. 183.

UNCRC 'Concluding Observations: St. Vincent' (13 June 2002) UN Doc CRC/C/15/Add. 184.

UNCRC ‘Concluding Observations: Spain’ (13 June 2002) UN Doc CRC/C/15/Add. 185.

UNCRC 'Concluding Observations: The Netherlands' (13 June 2002) UN Doc CRC/C/15/Add. 186.

UNCRC 'Concluding Observations: Argentina' (9 October 2002) UN Doc CRC/C/15/Add. 187.

UNCRC 'Concluding Observations: United Kingdom' (9 October 2002) UN Doc CRC/C/15/Add. 188.

UNCRC 'Concluding Observations: Seychelles' (30 October 2002) UN Doc CRC/C/15/Add. 189.

UNCRC ‘Concluding Observations: Sudan’ (9 October 2002) UN Doc CRC/C/15/Add. 190.

UNCRC 'Concluding Observations: Ukraine' (9 October 2002) UN Doc CRC/C/15/Add. 191.

UNCRC 'Concluding Observations: Moldova' (31 October 2002) UN Doc CRC/C/15/Add. 192. 
UNCRC 'Concluding Observations: Burkina Faso' (9 October 2002) UN Doc CRC/C/15/Add. 193.

UNCRC 'Concluding Observations: Poland' (30 October 2002) UN Doc CRC/C/15/Add. 194.

UNCRC 'Concluding Observations: Israel' (9 October 2002) UN Doc CRC/C/15/Add. 195.

UNCRC 'Concluding Observations: Estonia' (17 March 2003) UN Doc CRC/C/15/Add. 196.

UNCRC 'Concluding Observations: Republic of Korea' (18 March 2003) UN Doc CRC/C/15/Add. 197.

UNCRC ‘Concluding Observations: Italy’ (18 March 2003) UN Doc CRC/C/15/Add. 198.

UNCRC 'Concluding Observations: Romania' (18 March 2003) UN Doc CRC/C/15/Add. 199.

UNCRC 'Concluding Observations: Viet Nam' (18 March 2003) UN Doc CRC/C/15/Add. 200.

UNCRC 'Concluding Observations: Czech Republic' (18 March 2003) UN Doc CRC/C/15/Add. 201.

UNCRC 'Concluding Observations: Haiti’ (18 March 2003) UN Doc CRC/C/15/Add. 202.

UNCRC 'Concluding Observations: Iceland' (31 January 2003) UN Doc CRC/C/15/Add. 203.

UNCRC 'Concluding Observations: Eritrea’ (2 July 2003) UN Doc CRC/C/15/Add. 204.

UNCRC ‘Concluding Observations: Cyprus’ (2 July 2003) UN Doc CRC/C/15/Add. 205.

UNCRC ‘Concluding Observations: Zambia’ (2 July 2003) UN Doc CRC/C/15/Add. 206.

UNCRC 'Concluding Observations: Sri Lanka’ (2 July 2003) UN Doc CRC/C/15/Add. 207.

UNCRC 'Concluding Observations: Solomon Islands' (2 July 2003) UN Doc CRC/C/15/Add. 208.

UNCRC 'Concluding Observations: Libya Arab Jamahiriya' (4 July 2003) UN Doc CRC/C/15/Add. 209.

UNCRC ‘Concluding Observations: Jamaica’ (4 July 2003) UN Doc CRC/C/15/Add. 210.

UNCRC 'Concluding Observations: Morocco’ (10 July 2003) UN Doc CRC/C/15/Add. 211.

UNCRC 'Concluding Observations: Syrian Arab Republic' (10 July 2003) UN Doc CRC/C/15/Add. 212.

UNCRC 'Concluding Observations: Kazakhstan' (10 July 2003) UN Doc CRC/C/15/Add. 213. 
UNCRC 'Concluding Observations: San Marino' (27 July 2003) UN Doc CRC/C/15/Add. 214.

UNCRC 'Concluding Observations: Canada’ (27 July 2003) UN Doc CRC/C/15/Add. 215.

UNCRC 'Concluding Observations: New Zealand' (27 July 2003) UN Doc CRC/C/15/Add. 216.

UNCRC ‘Concluding Observations: Pakistan’ (27 July 2003) UN Doc CRC/C/15/Add. 217.

UNCRC 'Concluding Observations: Madagascar' (27 October 2003) UN Doc CRC/C/15/Add. 218.

UNCRC 'Concluding Observations: Brunei Darussalam' (29 July 2003) UN Doc CRC/C/15/Add. 219.

UNCRC ‘Concluding Observations: Singapore’ (27 July 2003) UN Doc CRC/C/15/Add. 220.

UNCRC 'Concluding Observations: Bangladesh' (27 July 2003) UN Doc CRC/C/15/Add. 221.

UNCRC 'Concluding Observations: Georgia' (27 July 2003) UN Doc CRC/C/15/Add. 222.

2004

UNCRC 'Concluding Observations: Indonesia' (26 February 2004) UN Doc CRC/C/15/Add. 223.

UNCRC 'Concluding Observations: Guyana' (26 February 2004) UN Doc CRC/C/15/Add. 224.

UNCRC 'Concluding Observations: Armenia' (26 February 2004) UN Doc CRC/C/15/Add. 225.

UNCRC 'Concluding Observations: Germany’ (26 February 2004) UN Doc CRC/C/15/Add. 226.

UNCRC 'Concluding Observations: Netherlands' (26 February 2004) UN Doc CRC/C/15/Add. 227.

UNCRC ‘Concluding Observations: India’ (26 February 2004) UN Doc CRC/C/15/Add. 228.

UNCRC 'Concluding Observations: Papua New Guinea' (26 February 2004) UN Doc CRC/C/15/Add. 229.

UNCRC 'Concluding Observations: Slovenia' (26 February 2004) UN Doc CRC/C/15/Add. 230 .

UNCRC 'Concluding Observations: Japan' (26 February 2004) UN Doc CRC/C/15/Add. 231. 
UNCRC 'Concluding Observations: El Salvador' (30 June 2004) UN Doc CRC/C/15/Add. 232.

UNCRC 'Concluding Observations: Panama' (30 June 2004) UN Doc CRC/C/15/Add. 233.

UNCRC ‘Concluding Observations: Rwanda’ (1 July 2004) UN Doc CRC/C/15/Add. 234.

UNCRC 'Concluding Observations: San Tome and Principe' (1 July 2004) UN Doc CRC/C/15/Add. 235.

UNCRC ‘Concluding Observations: Liberia’ (1 July 2004) UN Doc CRC/C/15/Add. 236.

UNCRC 'Concluding Observations: Myanmar' (30 June 2004) UN Doc CRC/C/15/Add. 237.

UNCRC 'Concluding Observations: Dominica Republic' (30 June 2004) UN Doc CRC/C/15/Ads. 238.

UNCRC 'Concluding Observations: Democratic People's Republic of Korea' (1 July 2004) UN Doc CRC/C/15/Add. 239.

UNCRC 'Concluding Observations: France’ (30 June 2004) UN Doc CRC/C/15/Add. 240.

UNCRC 'Concluding Observations: Brazil' (3 November 2004) UN Doc CRC/C/15/Add. 241.

UNCRC 'Concluding Observations: Botswana' (3 November 2004) UN Doc CRC/C/15/Add. 242.

UNCRC 'Concluding Observations: Croatia' (3 November 2004) UN Doc CRC/C/15/Add. 243.

UNCRC 'Concluding Observations: Kirgizstan' (3 November 2004) UN Doc CRC/C/15/Add. 244.

UNCRC 'Concluding Observations: Equatorial Guinea' (3 November 2004) UN Doc CRC/C/15/Add. 245.

UNCRC 'Concluding Observations: Angola' (3 November 2004) UN Doc CRC/C/15/Add. 246.

UNCRC 'Concluding Observations: Antigua and Barbuda' (3 November 2004) UN Doc CRC/C/15/Add. 247.

UNCRC 'Concluding Observations: Sweden' (30 March 2005) UN Doc CRC/C/15/Add. 248.

UNCRC 'Concluding Observations: Albania' (31 March 2005) UN Doc CRC/C/15/Add. 249. UNCRC 'Concluding Observations: Luxemburg' (31 March 2005) UN Doc CRC/C/15/Add. 250 .

UNCRC 'Concluding Observations: Austria’ (January 2005) UN Doc CRC/C/15/Add. 251. 
UNCRC ‘Concluding Observations: Belize’ (31 March 2005) UN Doc CRC/C/15/Add. 252.

UNCRC 'Concluding Observations: Bahamas' (31 March 2005) UN Doc CRC/C/15/Add. 253.

UNCRC 'Concluding Observations: Islamic Republic of Iran' (31 March 2005) UN Doc CRC/C/15/Add. 254.

UNCRC ‘Concluding Observations: Togo’ (31 March 2005) UN Doc CRC/C/15/Add. 255.

UNCRC 'Concluding Observations: Bolivia' (11 February 2005) UN Doc CRC/C/15/Add. 256.

UNCRC 'Concluding Observations: Nigeria’ (13 April 2005) UN Doc CRC/C/15/Add. 257.

UNCRC 'Concluding Observations: Saint Lucia' (21 September 2005) UN Doc CRC/C/15/Add. 258.

UNCRC 'Concluding Observations: Philippines' (21 September 2005) UN Doc CRC/C/15/Add. 259.

UNCRC 'Concluding Observations: Bosnia and Herzegovina' (21 September 2005) UN Doc CRC/C/15/Add. 260.

UNCRC 'Concluding Observations: Nepal' (21 September 2005) UN Doc CRC/C/15/Add. 261.

UNCRC 'Concluding Observations: Ecuador' (13 September 2005) UN Doc CRC/C/15/Add. 262.

UNCRC 'Concluding Observations: Norway' (21 September 2005) UN Doc CRC/C/15/Add. 263.

UNCRC 'Concluding Observations: Mongolia' (21 September 2005) UN Doc CRC/C/15/Add. 264.

UNCRC 'Concluding Observations: Nicaragua' (21 September 2005) UN Doc CRC/C/15/Add. 265.

UNCRC 'Concluding Observations: Costa Rica' (21 September 2005) UN Doc CRC/C/15/Add. 266.

UNCRC 'Concluding Observations: Yemen' (21 September 2005) UN Doc CRC/C/15/Add. 267.

UNCRC 'Concluding Observations: Austria' (20 October 2005) UN Doc CRC/C/15/Add. 268.

UNCRC 'Concluding Observations: Algeria' (12 October 2005) UN Doc CRC/C/15/Add. 269.

UNCRC 'Concluding Observations: Russian Federation' (23 November 2005) UN Doc $\mathrm{CRC} / \mathrm{C} / \mathrm{RUS} / \mathrm{CO} / 3$. 
UNCRC 'Concluding Observations: Uganda' (23 November 2005) UN Doc $\mathrm{CRC} / \mathrm{C} / \mathrm{UGA} / \mathrm{CO} / 2$.

UNCRC 'Concluding Observations: Finland' (20 October 2005) UN Doc CRC/C/15/Add. 272.

UNCRC 'Concluding Observations: China' (24 November 2005) UN Doc $\mathrm{CRC} / \mathrm{C} / \mathrm{CHN} / \mathrm{CO} / 2$.

UNCRC ‘Concluding Observations: Thailand' (17 March 2006) UN Doc CRC/C/THA/CO/2.

UNCRC 'Concluding Observations: Republic on Congo' (20 October 2006) UN Doc $\mathrm{CRC} / \mathrm{C} / \mathrm{COG} / \mathrm{CO} / 1$.

UNCRC 'Concluding Observations: Latvia' (28 June 2006) UN Doc CRC/C/LTC/CO/2.

UNCRC ‘Concluding Observations: Lebanon’ (8 June 2006) UN Doc CRC/C/LBN/CO/2.

UNCRC 'Concluding Observations: Lithuania' (17 March 2006) UN Doc $\mathrm{CRC} / \mathrm{C} / \mathrm{LTU} / \mathrm{CO} / 2$.

UNCRC ‘Concluding Observations: Benin’ (20 October 2006) UN Doc CRC/C/BEN/CO/2.

UNCRC 'Concluding Observations: United Republic of Tanzania' (21 June 2006) UN Doc $\mathrm{CRC} / \mathrm{C} / \mathrm{TZA} / \mathrm{CO} / 2$.

UNCRC ‘Concluding Observations: Mexico’' (2 June 2006) UN Doc CRC/C/MEX/CO/3.

UNCRC 'Concluding Observations: Jordan' (29 September 2006) UN Doc $\mathrm{CRC} / \mathrm{C} / \mathrm{JOR} / \mathrm{CO} / 3$.

UNCRC 'Concluding Observations: Ghana' (17 March 2006) UN Doc CRC/C/GHA/CO/2.

UNCRC 'Concluding Observations: Ireland' (29 September 2006) UN Doc $\mathrm{CRC} / \mathrm{C} / \mathrm{IRL} / \mathrm{CO} / 2$.

UNCRC 'Concluding Observations: Swaziland' (16 October 2006) UN Doc $\mathrm{CRC} / \mathrm{C} / \mathrm{SWZ} / \mathrm{CO} / 1$.

UNCRC 'Concluding Observations: Uzbekistan’ (2 June 2006) UN Doc CRC/C/UZB/CO/2.

UNCRC ‘Concluding Observations: Columbia’ (8 June 2006) UN Doc CRC/C/COL/CO/3.

UNCRC 'Concluding Observations: Azerbaijan' (17 March 2006) UN Doc $\mathrm{CRC} / \mathrm{C} / \mathrm{AZE} / \mathrm{CO} / 2$.

UNCRC ‘Concluding Observations: Uruguay’ (5 July 2007) UN Doc CRC/C/URY/CO/2.

UNCRC 'Concluding Observations: Kazakhstan' (19 June 2007) UN Doc $\mathrm{CRC} / \mathrm{C} / \mathrm{KAZ} / \mathrm{CO} / 3$.

UNCRC 'Concluding Observations: Venezuela' (5 October 2007) UN Doc $\mathrm{CRC} / \mathrm{C} / \mathrm{VEN} / \mathrm{CO} / 2$. 
UNCRC 'Concluding Observations: Kenya’ (19 June 2007) UN Doc CRC/C/KEN/CO/2.

UNCRC 'Concluding Observations: Malaysia' (25 June 207) UN Doc CRC/C/MYS/CO/1.

UNCRC 'Concluding Observations: Marshal Islands' (19 November 2007) UN Doc $\mathrm{CRC} / \mathrm{C} / \mathrm{MHL} / \mathrm{CO} / 2$.

UNCRC ‘Concluding Observations: Maldives’ (13 July 2007) UN Doc CRC/C/MDV/CO/3

UNCRC 'Concluding Observations: Bulgaria’ (23 June 2008) UN Doc CRC/C/BGR/CO/2.

UNCRC 'Concluding Observations: Georgia' (23 June 2008) UN Doc CRC/C/GEO/CO/3.

UNCRC 'Concluding Observations: Republic of Serbia' (20 June 2008) UN Doc $\mathrm{CRC} / \mathrm{C} / \mathrm{SRB} / \mathrm{CO} / 1$.

UNCRC 'Concluding Observations: Sierra Leone' (20 June 2008) UN Doc $\mathrm{CRC} / \mathrm{C} / \mathrm{SLE} / \mathrm{CO} / 2$.

UNCRC 'Concluding Observations: Djibouti' (7 October 2008) UN Doc CRC/C/DJI/CO/2.

UNCRC 'Concluding Observations: United Kingdom' (20 October 2008) UN Doc $\mathrm{CRC} / \mathrm{C} / \mathrm{GBR} / \mathrm{CO} / 4$.

UNCRC 'Concluding Observations: Dominican Republic' (11 February 2008) UN Doc $\mathrm{CRC} / \mathrm{C} / \mathrm{DOM} / \mathrm{CO} / 2$.

UNCRC 'Concluding Observations: Timor-Leste' (14 February 2008) UN Doc $\mathrm{CRC} / \mathrm{C} / \mathrm{TLS} / \mathrm{CO} / 1$.

UNCRC 'Concluding Observations: Democratic People's Republic of Korea' (27 March 2009) UN Doc CRC/C/PRK/CO/4.

UNCRC 'Concluding Observations: Democratic Republic of the Congo' (10 February 2009) $\mathrm{UN}$ Doc $\mathrm{CRC} / \mathrm{C} / \mathrm{COD} / \mathrm{CO} / 2$.

UNCRC 'Concluding Observations: Republic of Chad' (12 February 2009) UN Doc $\mathrm{CRC} / \mathrm{C} / \mathrm{TCD} / \mathrm{CO} / 2$.

UNCRC 'Concluding Observations: Bangladesh' (26 June 2009) UN Doc $\mathrm{CRC} / \mathrm{C} / \mathrm{BGD} / \mathrm{CO} / 4$.

UNCRC 'Concluding Observations: Romania’ (30 June 2009) UN Doc CRC/C/ROM/CO/4.

UNCRC 'Concluding Observations: The Plurinational State of Bolivia' (16 October 2009) $\mathrm{UN}$ Doc $\mathrm{CRC} / \mathrm{C} / \mathrm{BOL} / \mathrm{CO} / 4$.

UNCRC 'Concluding Observations: Pakistan' (15 October 2009) UN Doc $\mathrm{CRC} / \mathrm{C} / \mathrm{PAK} / \mathrm{CO} / 3-4$.

UNCRC 'Concluding Observations: The Philippines' (22 October 2009) UN Doc $\mathrm{CRC} / \mathrm{C} / \mathrm{PHL} / \mathrm{CO} / 3-4$. 
UNCRC 'Concluding Observations: Qatar' (14 October 2009) UN Doc CRC/C/QAT/CO/2.

UNCRC 'Concluding Observations: Burkina Faso' (29 January 2010) UN Doc $\mathrm{CRC} / \mathrm{C} / \mathrm{BFA} / \mathrm{CO} / 3-4$.

UNCRC 'Concluding Observations: Ecuador' (29 January 2010) UN Doc $\mathrm{CRC} / \mathrm{C} / \mathrm{ECU} / \mathrm{CO} / 4$.

UNCRC 'Concluding Observations: El Salvador' (17 February 2010) UN Doc $\mathrm{CRC} / \mathrm{C} / \mathrm{SLV} / \mathrm{CO} / 3-4$.

UNCRC 'Concluding Observations: Mongolia' (29 January 2010) UN Doc $\mathrm{CRC} / \mathrm{C} / \mathrm{MNG} / \mathrm{CO} / 3-4$.

UNCRC 'Concluding Observations: Norway’ (3 March 2010) UN Doc CRC/C/NOR/CO/4.

UNCRC 'Concluding Observations: Paraguay' (10 February 2010) UN Doc $\mathrm{CRC} / \mathrm{C} / \mathrm{PRY} / \mathrm{CO} / 3$.

UNCRC 'Concluding Observations: Tajikistan' (5 February 2010) UN Doc $\mathrm{CRC} / \mathrm{C} / \mathrm{TJK} / \mathrm{CO} / 2$.

UNCRC 'Concluding Observations: Argentina' (11 June 2010) UN Doc CRC/C/ARG/CO/34.

UNCRC ‘Concluding Observations: Belgium’ (18 June 2010) UN Doc CRC/C/BEL/CO/3-4.

UNCRC 'Concluding Observations: The Former Yugoslav Republic of Macedonia' (11 June 2010) UN Doc CRC/C/CO/2.

UNCRC ‘Concluding Observations: Japan’ (20 June 2010) UN Doc CRC/C/JPN/CO/3.

UNCRC 'Concluding Observations: Nigeria' (11 June 2010) UN Doc CRC/C/NGA/CO/3-4.

UNCRC 'Concluding Observations: Angola' (11 October 2010) UN Doc CRC/C/CO/2-4.

UNCRC ‘Concluding Observations: Burundi’ (1 October 2010) UN Doc CRC/C/BDI/CO/2.

UNCRC 'Concluding Observations: Guatemala' (1 October 2010) UN Doc $\mathrm{CRC} / \mathrm{C} / \mathrm{GTM} / \mathrm{CO} / 3-4$.

UNCRC 'Concluding Observations: Spain' (29 September 2010) UN Doc CRC/C/ESP/CO/3-4.

UNCRC 'Concluding Observations: Sudan’ (1 October 2010) UN Doc CRC/C/SDN/CO/3-4. 